Andrews University

Digital Commons @ Andrews University

2012

\title{
A University Course's Influence on Students' Perpectives Regarding Sabbathkeeping as Spiritual Discipline
}

Ifeoma I. Kwesi

Andrews University

Follow this and additional works at: https://digitalcommons.andrews.edu/dmin

Part of the Practical Theology Commons

\section{Recommended Citation}

Kwesi, Ifeoma I., "A University Course's Influence on Students' Perpectives Regarding Sabbathkeeping as Spiritual Discipline" (2012). Professional Dissertations DMin. 476.

https://dx.doi.org/10.32597/dmin/476

https://digitalcommons.andrews.edu/dmin/476

This Project Report is brought to you for free and open access by the Graduate Research at Digital Commons @ Andrews University. It has been accepted for inclusion in Professional Dissertations DMin by an authorized administrator of Digital Commons @ Andrews University. For more information, please contact repository@andrews.edu. 


\section{ABSTRACT}

\section{A UNIVERSITY COURSE'S INFLUENCE \\ ON STUDENTS' PERSPECTIVES REGARDING \\ SABBATHKEEPING AS SPIRITUAL DISCIPLINE}

by

Ifeoma I. Kwesi

Adviser: O. Jane Thayer 


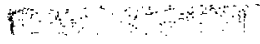 \\ $(-2, \cdots$ \\ ABSTRACT OF GRADUATE STUDENT RESEARCH \\ Project Dissertation \\ Andrews University \\ Seventh-day Adventist Theological Seminary
}

Title: A UNIVERSITY COURSE'S INFLUENCE ON STUDENTS' PERSPECTIVES REGARDING SABBATHKEEPING AS SPIRITUAL DISCIPLINE

Name of Researcher: Ifeoma I. Kwesi

Name and degree of faculty adviser: O. Jane Thayer, Ph.D.

Date completed: December 2012

\title{
Problem
}

Although most students who attend Oakwood University are self-identified

Seventh-day Adventist Christians, from general observation of their activities, conversations, and attitudes displayed on any given Friday night and/or Saturday (i.e., Sabbath), it would be easy to conclude that many neither enter nor exit their collegiate experience with a holistic understanding or experience of Sabbath and Sabbathkeeping.

\section{Methodology}

1. As part of the research for this project I used a pre- and post-test methodology to determine the cognitive, behavioral and affective realms of Sabbath and Sabbathkeeping among students enrolled in RP131: Spiritual Formation for Ministry. 
The intervention was the aforementioned semester-long course which included weekly reading reports, weekly reports of the practice of the spiritual disciplines, reflection papers, resource files, a Sabbath service at a local synagogue, a weekend retreat emphasizing God's special presence on Sabbath, and retreat evaluations.

2. My reflection on the Old and New Testaments as well as relevant passages from the writings of Ellen G. White, biblical scholars and theologians regarding Sabbath and Sabbathkeeping provided the foundations for this project.

3. I reviewed current literature on religious/theological education philosophy and curriculum in colleges and universities (in general and in Seventh-day Adventist institutions); postmodernism; spiritual formation (including spirituality and spiritual development within the context of developmental theories); biblical and theological moorings for spiritual formation; spiritual formation courses in religious/theological education (in general and in Seventh-day Adventist college and universities); the relationship of spiritual formation and/or spiritual formation course to university students; the relationship of spiritual formation and/or spiritual formation courses to African American university students; the influence of spiritual disciplines; the influence of spiritual disciplines on university students; the influence of spiritual disciplines on African American university students; the influence of the spiritual discipline of Sabbath/ Sabbathkeeping; and the influence of the spiritual discipline of Sabbath/Sabbathkeeping on African American university students. The scholarship is these areas shaped and informed my research in both widening and narrowing the aperture of the lens through which I constructed the intervention to be implemented to examine and address a theological issue in ministry. 
4. The details of the research methodology and implementation are described in Chapter 4. Outcomes and evaluations are presented in Chapter 5 and conclusions and recommendations are summarized in Chapter 6.

5. Again, the purpose of this dissertation was to examine a theological issue in ministry, namely, the influence of a spiritual formation course on the perspectives of Sabbath/ Sabbathkeeping as a spiritual discipline among African-American Oakwood University students. Another important objective was to provide the means by which students would be able to differentiate between Sabbath/Sabbathkeeping as a spiritual discipline and Sabbath/Sabbathkeeping as propositional truth and to evaluate the significance of the difference. Details of the course and the survey instrument are given in Chapter 5.

\section{Results}

All of the quantitative data, which reflected the differences in the pre- and posttest means, indicated positive outcomes. Key positive outcomes are the following:

- Students who initially perceived Sabbath as a "burden" came to understand it as a "delight" and "good news."

- Students" understanding related to Sabbathkeeping as a time of "no work" and a time for family improved.

- Students' understanding of spiritual formation as a process that is not under human control increased.

- Students who initially perceived of spiritual disciplines as "spiritual restrictions, punishment or rules for salvation" came to understand them as "the door to liberation." 
- Students' understanding of the relationship between "being a good member of a church" and obtaining salvation improved.

The qualitative data indicate that the influence of the spiritual formation course on Sabbath and Sabbathkeeping as a spiritual discipline has been a positive intervention, particularly in the area of anticipated commitment to Sabbathkeeping beyond graduation.

\section{Conclusions}

A college-level spiritual formation course that encourages an intimate, loving relationship with the Lawgiver Who is the Creator and Lord of the Sabbath as the means for appreciating and enjoying Sabbath as a special time to be with Him can change the perspectives of students who view Sabbath negatively to perceiving it positively, joyfully, correctly, holistically, relationally, and with greater commitment.

A college-level spiritual formation course that provides biblical instruction on Sabbath and Sabbath observance in the context of spiritual formation as a balance of dependence on the power of the Holy Spirit and "discipline for the purpose of godliness" (1 Tim 4:7) through the examination of and engagement in the spiritual disciplines that are foundational to spiritual formation, a strong devotional life, and Spirit-led Christian service can change the perspectives of students who do not regard Sabbath and Sabbath observance as a spiritual discipline to acknowledging Sabbath and Sabbath observance as one of the means by which the Holy Spirit transforms human beings into "partakers of the divine nature" (2 Peter 1:4). 


\title{
Andrews University
}

Seventh-day Adventist Theological Seminary

\section{A UNIVERSITY COURSE'S INFLUENCE ON STUDENTS' PERSPECTIVES REGARDING SABBATHKEEPING AS SPIRITUAL DISCIPLINE}

\author{
A Project Dissertation \\ Presented in Partial Fulfillment \\ of the Requirements for the Degree \\ Doctor of Ministry
}

by

Ifeoma I. Kwesi

December 2012 
(C) Copyright by Ifeoma I. Kwesi 2012 All Rights Reserved 


\title{
A UNIVERSITY COURSE'S INFLUENCE ON STUDENTS' PERSPECTIVES REGARDING SABBATHKEEPING AS SPIRITUAL DISCIPLINE
}

\author{
A project dissertation \\ presented in partial fulfillment \\ of the requirements for the degree \\ Doctor of Ministry
}

by

Ifeoma I. Kwesi

APPROVAL BY THE COMMITTEE:

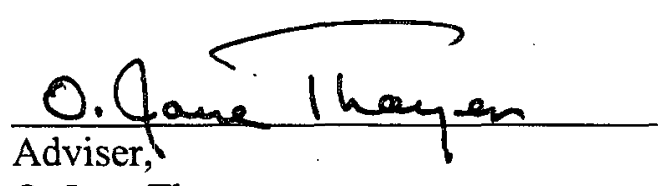

O. Jane Thayer
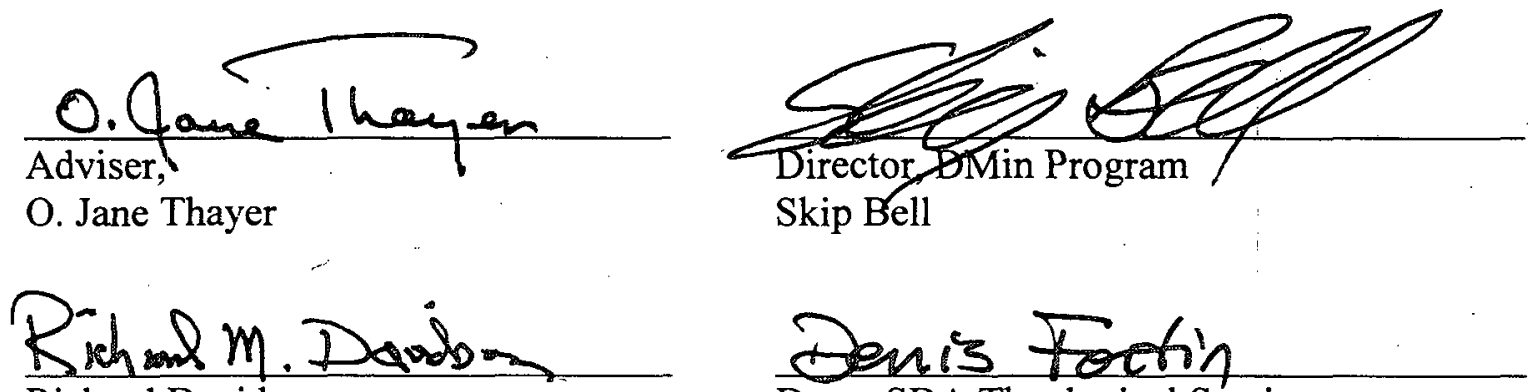

Richard Davidson Dean, SDA Theological Seminary

Denis Fortin
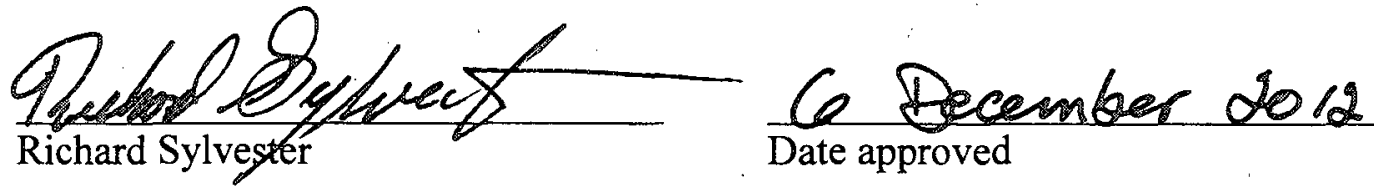


\section{TABLE OF CONTENTS}

LIST OF ILLUSTRATIONS ....................................................................... vii

LIST OF TABLES .......................................................................................... vii

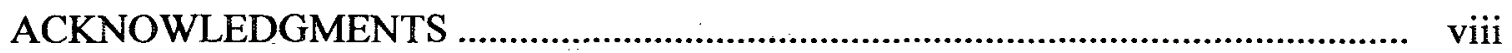

Chapter

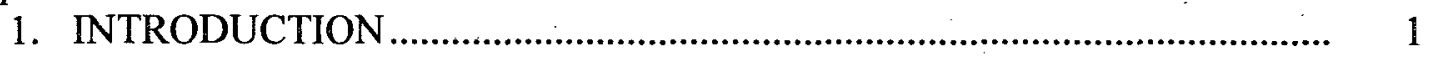

Personal History ....................................................................................

Statement of Task ……............................................................................ 9

Statement of the Problem................................................................... 10

Statement of Justification.................................................................. 11

Expectations for the Project ...................................................................... 13

Delimitations ..................................................................................... 14

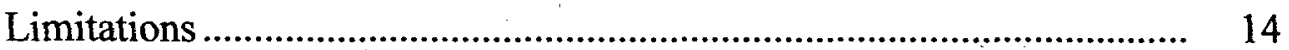

Definition of Terms......................................................................... 15

African American........................................................................ 15

Oakwood University ....................................................................... 16

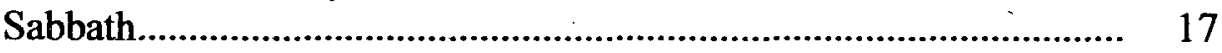

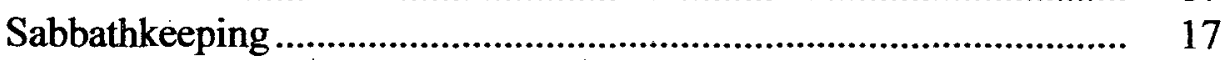

Seventh-day Adventist .................................................................... 18

Spiritual Discipline .................................................................. 18

Spiritual Formation ...................................................................... 19

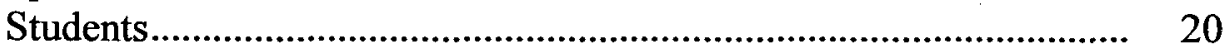

Methodology ........................................................................................... 21

Summary of the Chapters............................................................................ 23

2. BIBLICAL AND THEOLOGICAL FOUNDATIONS …….......................... 26

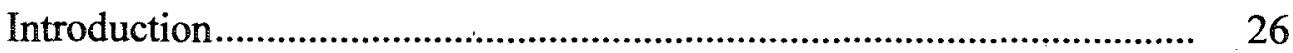

Hermeneutical Considerations .............................................................. 26

Biblical Evidence for Sabbath Observance............................................. $\quad 28$

Old Testament Evidence of Sabbath Observance ............................... 28

Evidence of Sabbath Observance from the Pentateuch ............... 28

Evidence of Sabbath Observance from the Historical and

Prophetic Books 
Evidence of Sabbath Observance from the Psalms \& Wisdom

Literature

New Testament Evidence of Sabbath Observance ................................. $\quad 45$

Evidence of Sabbath Observance from the Gospels ......................... 45

Evidence of Sabbath Observance from Acts of the Apostles ............ 51

Evidence of Sabbath Observance from the Epistles .......................... 52

Biblical Descriptions and Significance of Sabbath Observance............... $\quad 58$

Old Testament Descriptions and Significance of Sabbath

Observance

Descriptions and Significance of Sabbath Observance from the

Pentateuch

Descriptions and Significance of Sabbath Observance from the Historical and Prophetic Books

Descriptions and Significance of Sabbath Observance from the

Psalms and Wisdom Literature

New Testament Descriptions and Significance of Sabbath

Observance.

Descriptions/Significance of Sabbathkeeping from the Gospels in Non-Controversy

Descriptions/Significance of Sabbathkeeping from the Gospels Involving Controversial Incidents

Descriptions/Significance of Sabbath Observance from Acts of the Apostles

Descriptions/Significance of Sabbath Observance from the Epistles

Theological Perspectives on Biblical Indicators of the

Universal and Permanent Applicability of Sabbath

Observance.

Summary and Conclusions

3. LITERATURE REVIEW

Introduction

Postmodern/Postmodernism: Definitions, Interpretations, and

Implications.

Spiritual Formation

Overview of Nomenclature: Designations, Definitions, and

Distinctions

Spirituality vs. Religion

Self-referenced Spirituality

Christ-centered Biblical Spirituality

Seventh-day Adventist Christian Views of Spirituality ......... 89

Spiritual Formation vs. Spiritual Development ........................................ 91

Theories of Human Development :................................................... 92

Theories of Spiritual Development.................................................. 95

Contemporary Interpretations of Spiritual Formation ............................. 99 
Religious/Theological Education in Colleges/ Universities in the

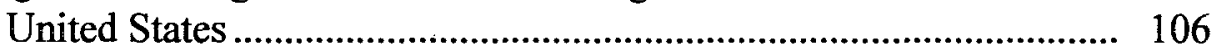

Philosophy........................................................................... 106

Curriculum ......................................................................... 113

Religious/Theological Education in SDA Colleges/Universities in the

United States .............................................................................. 118

Philosophy.......................................................................... 119

Curriculum ....................................................................... 124

Spiritual Formation Courses in Religious/Theological Education .......... 127

Spiritual Formation Courses in American Colleges and

Universities

Spiritual Formation Courses at American SDA Colleges and Universities

Spiritual Formation of Collegians/Emerging Adults

Spiritual Formation of African American Collegians/Emerging

Adults

Influence of Spiritual Disciplines on Collegians/Emerging Adults 144

Influence of Spiritual Disciplines on African American Collegians ....... 15

Influence of the Spiritual Discipline of Sabbathkeeping ......................... 152

Jewish Perspectives....................................................................... 153

First-day Christian Perspectives ................................................. 153

Seventh-day Adventist Christian Perspectives ................................ 156

Influence of Sabbathkeeping Spiritual Discipline on University

Students.

Influence of Sabbathkeeping Spiritual Discipline on African

American Collegians..................................................................... 160

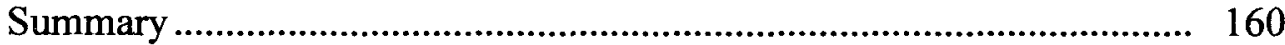

Conclusions .................................................................................... 160

4. METHODOLOGY AND IMPLEMENTATION NARRATIVE .................... 161

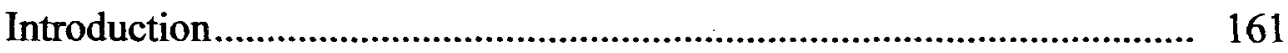

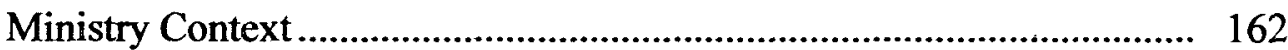

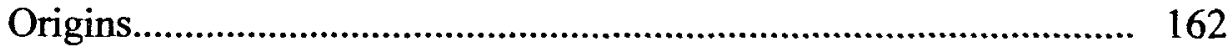

Oakwood University ...................................................................... 162

Department of Religion and Theology ........................................... 164

RP131: Spiritual Formation for Ministry........................................ 164

Research Methodology ..................................................................... 166

Description of Research Methodology ............................................ 166

Interpretation of Data ....................................................................... 166

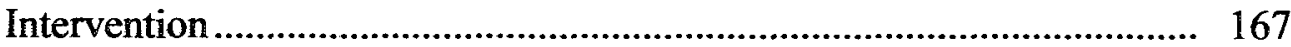

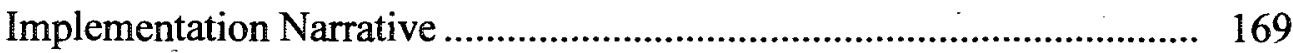

Course Description..................................................................... 169

Retreat Description ……................................................................... 173

Conclusion ....................................................................................... 181 
5. OUTCOMES AND EVALUATION

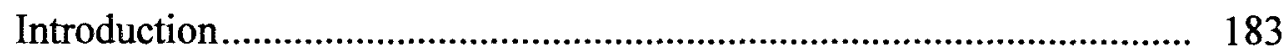

Description of Research Methodology .......................................... 175

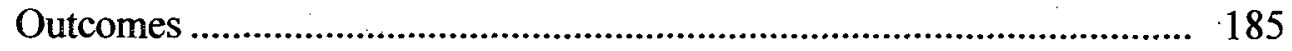

Interpretation of Quantitative Data ............................................... 185

Evaluation of Quantitative Data..................................................... 193

Interpretation of Qualitative Data ................................................ 194

Evaluation of Qualitative Data..................................................... 205

6. SUMMARY, CONCLUSIONS, AND RECOMMENDATIONS................. 207

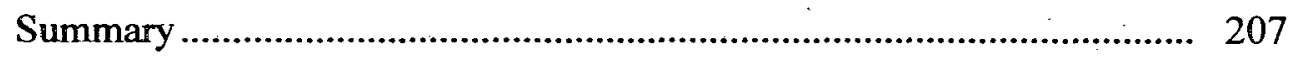

Conclusions and Recommendations for Practice................................. 213

Recommendation for Additional Research .......................................... 219

Appendix

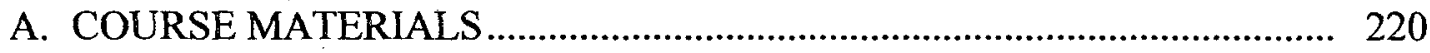

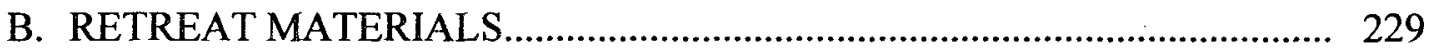

C. STUDENT REFLECTION PAPER REFERENCES TO SABBATH/

SABBATHKEEPING ................................................................... 238

D. STUDENT RESOURCE FILE REFERENCES TO SABBATH/

SABBATHKEEPING ..................................................................... 260

E. PHOTOGRAPHS OF CLASS GIFT TO PROFESSOR KWESI:

SHABBAT FOUNTAIN ................................................................... 275

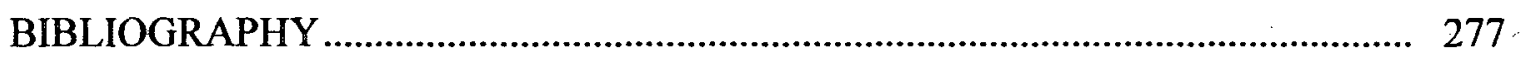

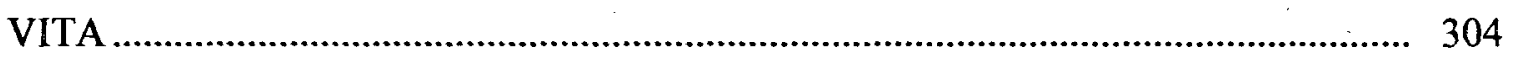




\section{LIST OF ILLUSTRATIONS}

1. The Sabbatic Chiastic Structure of the Psalm ...................................................... 42

2. Seven Spiritual Traditions of Black Churches..................................................... 87

\section{LIST OF TABLES}

1. Differences in Pre- and Post-Test Means for Understanding Sabbath................... 186

2. Differences in Pre- and Post-Test Means for Understanding Sabbathkeeping ....... 188

3. Differences in Pre- and Post-Test Means for Understanding Spiritual Formation

4. Differences in Pre- and Post-Test Means for Understanding Spiritual

Disciplines.

5. Differences in Pre- and Post-Test Means for Understanding Obtaining

Salvation

6. Pre-test/Post-Test Differences in Sabbath Activities

7. Differences in "What You Refrain From Doing to Keep the Sabbath Holy" 198

8. Differences in Attitude Change About the Seventh Day as Sabbath. 200

9. Differences in Attitude Change About Sabbathkeeping 201

10. Differences in Anticipated Future Commitment to Sabbathkeeping 203

11. Differences in Qualitative Kinesthetic/Behavioral Responses by Category 204 


\section{ACKNOWLEDGMENTS}

Divine: Father God, Jesus the Christ, Holy Spirit and all the angelic hosts of heaven

Family: Novella and Frank W. Hale, Sr., Ruth and Frank W. Hále, Jr., Mignon Scott Hale, Irene and Frank W. Hale, III, Sherilyn and Allen Wilkins, Christina Thomas, Charles Thomas, Jr., Renene Price, Ryan Price, Jordan Price, Maya Price, Shiloh and Frank W. Hale, IV, Lucille Lacy, Mary Howard, Chanel Fubler, Kelly and Royce Malcolm, Gloria Thomas, Sharon Thomas, Karen and James Coleman, Donna Coleman, Thea and Thomas Saddler, Aurora and Gary Saddler, Ryanne and Jay Saddler, Andrea Muhammed, Marian Patterson, Elfleda Tate

Oakwood University Administration, Faculty and Staff: Leslie Pollard, Garland Dulan, John Anderson, Roy Malcolm, Agniel Samson, Paulette Johnson, Elizabeth Mosby, Elaine Gray, Gretchen Scott, Shelly Vaughn, Dominique Patton, Carol Allen, Theodore Brown, Cherryl Galley, Janice Watson, Kyna Hinson, Gregory Allen, Finbar Benjamin, Keith Burton, James Doggette, Trevor Fraser, Tarsee Li, James Melancon, Gilbert Ojwang, Isaac Olatunji, Russell Seay, Lance Shand, Hurford Thómas, Jesse Wilson, George Lee Andrew's University Administration, Faculty and Staff: Skip Bell, Clifford Jones, Yvonne Applewhite, Terry Robertson, Muritha Mutale, Jane Thayer, Jerome Thayer, 
Richard Davidson, Jo Ann Davidson, Jon Dybdahl, Joseph Kidder, Allan Walsh, James North

Academic Consultants: Malcolm Cort, Janice Watson, Monte Sahlin, Patricia Mutch, Art Bacon

Spiritual Leaders: Ben Wade, T. Marshall Kelly, Charles Bradford, Harold Goodloe, Ben Jones, Craig Newborn, Antoine Maycock, John Nixon, Hyveth Williams, Lola Moore, Adrienne Townsend, Dilys Brooks, Delroy Brooks, Robert Willis, Paula Fuller, Glandion Carney, M. Robert Mulholland, Jr., Donald Burden, Shawn Arthur, Mic Thurber, Steve Bramwell, Steve Constantine, Walter Douglas, Jacqueline Lynch, DiedraAnn Lieba, Rebecca Davis, Alexis Madrid, Harold Lee

Students: RP131-01 and RP131-02 (Spring Semester 2009), Brittany Hill, Ariel

Hulum, Loreal McIness, Tanya Loveday, Andrew Pileggi, Datrean Pileggi, Erin Norwood, Myrtha Noel, Aisha Allsop, Farron Kennedy, Dee and Isaac Ibarra, Jason O’Rourke, Jillian Lawrence, Arthur Jennings, Jonathan Grant, Adia Taliaferro, Kristopher Brice

Friends: Linda Ammons, Wanda Porter, Beverly Vaughn, Melva Clark, Frieda LaPaugh, Cynthia Williams, James Price, Karen Richard, Curtis Craft, Darlene Collins, Debra Goodloe, Connie Maycock, Bettye Drake, Carlotta Doss, Edith Fraser, Sharon and Lester Houston, Robin and George Daly, Glenda Burrell, Jacqui and Oliver Shipe, Juanita Love, Rosa West, Larry Young, Margaret Dawkins, Joan and Russell Tynes, Ben Wade, Linda and Robert Smith, Cheryl Hazel, Robin Tait, Kimberly Jennings, Bettye Willis, Leslie Willis, Lizette Willis, Demetries Neely, Paul Cook, Sr., George Miller, 
Glenda Gill, Dionne Lynch Finney, Babbie and Charles Mason, Bonita Scott, Bernie Beck, Patsy Constantine, Tamara Birks, Yvonne Douglas, Janis Newborn 


\section{CHAPTER 1}

\section{INTRODUCTION}

\section{Personal History}

At the beginning of Fall Semester 1990, first-year students in the Master of Divinity program of the Seventh-day Adventist Theological Seminary at Andrews University were given the opportunity to choose a two-and-a-half day colloquium to attend from a listing of a dozen options. I was among those students, though significantly older than most, and had run from the calling in my life for a preaching ministry since I was twelve years of age. A third-generation Seventh-day Adventist who had only recently begun to be acquainted with Jesus personally, I was immediately intrigued by the topic: "Spiritual Formation: How to Experience the Power and Presence of God in Your Life and Ministry." I was even more inclined to investigate this subject when I noticed that the presenters, Derek Morris and Delcy Kuhlman, had chosen to offer this colloquium at a nearby retreat center called "Still Waters."

Although neither "spiritual formation" nor "retreat center" was in my vocabulary at that time, I believe it was an appointed moment in my journey. Historically, I had always been characterized as a "Type A" personality and had been socialized to regard performance and productivity as evidence of value. I was a perfectionist and a workaholic without realizing the destructive nature of either orientation. But "as a deer longs for flowing streams, so my soul" (Ps 42:1 NRSV) longed for this instruction on 
learning to be quiet and on being rather than doing in that beautiful setting in nature at the commencement of my ministerial training. My life changed dramatically September 2528,1990 , as I came to understand the value of practicing spiritual disciplines as the means of being still and knowing God.

Even before graduating and pastoring churches, I used the information and experience of that colloquium as the basis of worship programming in the residence hall where I served as a graduate assistant and as seminar/workshop material for gatherings beyond the campus. Later I conducted prayer meeting series and preached on the spiritual disciplines of spiritual formation in each of the churches I pastored. So I was more than delighted when invited to join the faculty of the Religion and Theology Department at Oakwood University, specifically to teach spiritual formation. The chair of the Department of Religion and Theology recommended that I consider using as textbooks for the spiritual formation courses, Invitation to a Journey by M. Robert Mulholland, Jr. and Celebration of Discipline by Richard J. Foster along with Steps to Christ by Ellen G. White. These three authors became the most influential on my thinking about spiritual formation.

It was also my pleasure to earn certification from the Academy for Spiritual Formation at the end of two years of worship, learning and fellowship with this disciplined community that emphasizes holistic spirituality.

The Academy for Spiritual Formation is a two-year covenant learning environment which combines academic learning and experiences in spiritual disciplines. Each Academy is two years in length and participants meet in residence for five days each calendar quarter....

A typical schedule for each residence period includes two prayer services each day (Morning Prayer and Night Prayer); Eucharistic Celebrations (combined with Evening Prayer); Silence; Covenant Group Meetings; morning and afternoon curriculum sessions; and spiritual reading. Participants typically participate in 
between residence periods in such activities are journaling; physical fitness; reading of assigned texts; and a project for ministry in spiritual formation. ${ }^{1}$

The Academy for Spiritual Formation is one of five programs provided by The Upper Room, "a global ministry dedicated to supporting the spiritual formation of Christians seeking to know and experience God more fully."2 Headquartered in Nashville, Tennessee, The Upper Room "includes publications, programs, prayer support, and other resources to help believers of all ages and denominations move to a deeper level of faith and service."3

"During each two-year academy, a total of sixteen courses are offered. These courses, taught by outstanding scholars and leaders in today's church, offer insights into the history and development of Christian spirituality.", One of those "outstanding scholars" was M. Robert Mulholland, Jr. who has since become a true companion on the journey. As the participants at the Academy for Spiritual Formation traced Christianity's rich spiritual heritage from our Jewish roots, through New Testament spirituality, Catholic, Protestant, and Orthodox spirituality and contemporary expressions of spirituality, I remember wishing that there was some specific contribution that Adventism could make to this body of study and practice.

The spiritual growth that resulted has greatly benefited me personally and professionally. Much of my passion in teaching spiritual formation and facilitating

${ }^{1}$ Upper Room, Academy for Spiritual Formation, What Is the Academy? http://www.upperroom .org/academy/whatistheacademy.asp (accessed July 2, 2009).

${ }^{2}$ Upper Room, About Us, http://www.upperroom.org/about/ (accessed July 2, 2009).

${ }^{3}$ Ibid.

${ }^{4}$ Upper Room, Academy for Spiritual Formation. 
spiritual retreats was kindled by lessons learned at Still Waters and at the Academy. But the special blessing is the lens those lessons gave me through which I was able to begin viewing Sabbath/Sabbathkeeping as a spiritual discipline in the spiritual formation of Seventh-day Adventist Christians and all Christians. Commenting on a vision she had in 1847 , Ellen White wrote, "At the commencement of the time of trouble, we were filled with the Holy Ghost as we went forth and proclaimed the Sabbath more fully"5 (italics supplied). The more I studied this concept, the more excited I became about the possibilities for African American Oakwood University students enrolled in RP131: Spiritual Formation for Ministry to have their understanding and experience of Sabbath and Sabbathkeeping transformed into what the Creator God originally intended.

Even the most casual perusal of seminary bulletins in the twenty-first century would reveal the inclusion of spiritual formation and pastoral theology as sub-fields of practical theology. In their book, Foundations for a Practical Theology of Ministry, James Poling and Donald Miller define practical theology as "critical and constructive reflection within a living community about human experience and interaction, involving a correlation of the Christian story and other perspectives, leading to an interpretation of meaning and value, and resulting in everyday guidelines and skills for the formation of persons and communities."

Dallas Willard proffers that "practical theology studies the manner in which our

${ }^{5}$ Ellen G. White, Early Writings (Washington, DC: Review and Herald, 1945), 33.

${ }^{6}$ James N. Poling and Donald E. Miller, Foundations for a Practical Theology of Ministry (Nashville: Abingdon Press, 1985), 62. 
actions interact with God to accomplish His ends in human life."7 He elaborates as follows:

Practical theology's overall task is, in effect, to develop for practical implementation the methods by which women and men interact with God to fulfill the divine intent for human existence. That intent for the church is twofold: the effective proclamation of the Christian gospel to all humanity, making "disciples" from every nation or ethnic group, and the development of those disciples' character into the character of Christ Himself "teaching them to do all things whatsoever I have commanded you" (Matthew 28:20).

"The development of those disciples' character into the character of Christ Himself" is the essence of spiritual formation which M. Robert Mulholland Jr. defines as "the process of being conformed to the image of Christ for the sake of others."

Practical/pastoral theology, as lived experience, utilizes a tool known as the pastoral cycle, pastoral circle, doing theology spiral, or pastoral spiral. For the purposes of this project, the term "pastoral cycle" will be used to describe "a method of analysis and questioning not only of problems or concerns that are faced but also what causes them and what obstacles need to be overcome."10

In his book Practical Theology: An Introduction, Richard Osmer states that "practical theological interpretation involves four key tasks: the descriptive-empirical, the interpretive, the normative, and the pragmatic."11 The descriptive-empirical task gathers

${ }^{7}$ Dallas Willard, The Spirit of the Disciplines: Understanding How God Changes Lives (San Francisco: HarperSanFrancisco, 1988), 14.

${ }^{8}$ Willard, The Spirit of the Disciplines, 15.

${ }^{9}$ M. Robert Mulholland Jr., Shaped by the Word: The Role of Scripture in Spiritual Formation (Nashville: Upper Room Books, 2000), 25.

${ }^{10}$ New Way of Being Church, "The Pastoral Cycle," http://www.newway.org.uk/datasheets/ pastoral_cycle.php (accessed September 7, 2009). 2008), 10 .

"Richard R. Osmer, Practical Theology: An Introduction (Grand Rapids, MI: Wm. B. Eerdmans, 
information for the purpose of discovering patterns and the forces producing or governing specific events, circumstances, and surrounding influences. The interpretive task pulls from the historical, sociological, and psychological perspectives to discern and demonstrate why these patterns and forces are occurring. The normative task utilizes theological concepts "to interpret particular episodes, situations or contexts, constructing ethical norms to guide our responses, and learns from 'good practice'."12 And the pragmatic task determines "strategies of action that will influence situations in ways that are desirable and enters into a reflective conversation with the 'talk back' emerging when they are enacted." 13

Practical theology is the theological approach chosen as the lens for this research on the influence of a spiritual formation course on the perspectives of African American Oakwood University (Oakwood) students on Sabbath and Sabbathkeeping as a spiritual discipline. For the purposes of this study, practical theological interpretation will be referred to simply as a spiral that "constantly circles back to tasks that have already been explored." $" 14$

I have chosen to use Osmer's tasks of practical theology to provide a conceptual framework for this dissertation in the following manner: (1) to gather information for the purpose of discovering patterns and forces producing or governing the lived experience or perspectives of African American Oakwood University students regarding Sabbath and Sabbathkeeping (Descriptive-Empirical Task of Chapter 1: Introduction); (2) to utilize

\footnotetext{
${ }^{12}$ Osmer, Practical Theology, 4.

${ }^{13}$ Ibid.

${ }^{14} \mathrm{Ibid}$.
} 
theological concepts "to interpret particular episodes, situations or contexts, constructing ethical norms to guide our responses, and learn from 'good practice""15 regarding Sabbath and Sabbathkeeping (Normative Task of Chapter 2: Biblical/Theological Foundations); (3) to pull from the historical, sociological and psychological perspectives to discern and demonstrate why these patterns and forces are occurring with respect to Sabbath and Sabbathkeeping (Interpretive Task of Chapter 3: Literature Review); (4) to provide Pastoral Action that will "determine strategies of action that will influence situations [Sabbath and Sabbathkeeping] in ways that are desirable and enter into a reflective conversation with the 'talk back' emerging when they are enacted"16 (Pragmatic Task of Chapter 4: Methodology and Implementation Narrative); and (5) to "circle back to tasks that have already been explored"17 to reveal the outcomes of the research, evaluate the intervention, interpret the data and draw conclusions from it (Descriptive-Empirical Task of Chapter 5: Outcomes and Evaluation).

The Descriptive-Empirical task of the Pastoral Cycle seeks to discover the lived experience. During my ten years of serving on the faculty in the Department of Religion and Theology at Oakwood University, I have observed that many African-American Oakwood University students experience Sabbath and Sabbathkeeping negatively and/or partially. Some totally disregard the day by sleeping and otherwise relaxing the entire day while others ignore it by doing exactly what they do the rest of the week. Many students regard it somewhat by refraining from some secular activities and participating

\footnotetext{
${ }^{15}$ Osmer, Practical Theology, 4.

${ }^{16}$ Ibid.

${ }^{17}$ Ibid., 11.
} 
in religious ones but their reasons for doing so are faulty, often motivated primarily by the desire for fellowship or a sense of obligation based on prior religious instruction and experiences. Still others who observe it to some extent refrain from secular activities and participate in religious ones do so with attitudes of resentment due to fear of institutional reprisals and/or God's wrath.

The Descriptive-Empirical task of the Pastoral Cycle also seeks to discern what changes are needed and it is the position of this research endeavor that African American Oakwood University students need to experience Sabbath and Sabbathkeeping according to God's ideal, positively and fully. This stage also inquires about the knowledge and experience of the ministry professional regarding the issue and as a third generation Seventh-day Adventist who became a Christian at the age of forty, I have lived all the distorted realities of Sabbath/Sabbathkeeping described above.

"Who is affected and how?" are further questions the Descriptive-Empirical task of the Pastoral Cycle seeks to answer. Although some administrators, faculty, and staff of Oakwood University may also fail to experience Sabbath and Sabbathkeeping according to God's ideal, the aforementioned students are most negatively affected due to their immaturity. "Our culture establishes the meaning, the value, the purpose, even the self-image of persons on the basis of function." ${ }^{18}$ As such, youth and young adults, longing for belonging and acceptance, are particularly influenced by peers who rarely regard religion and religious practices as being "cool." Sabbath and Sabbathkeeping according to God's ideal are completely counter-cultural yet they inform every aspect of life such that without a holistic experience of Sabbath and Sabbathkeeping to remind

\footnotetext{
${ }^{18}$ Mulholland, Shaped by the Word, 85.
} 
them of who they are and Whose they are, all human relationships, decisions, and interactions are flawed and potentially destructive.

Finally, the Descriptive-Empirical task of the Pastoral Cycle asks "What is happening to the people?" Many multi-generational African American, Seventh-day Adventist Christian, Oakwood University students have always refrained from secular activities on Sabbath and participated in religious ones without understanding or conviction. Some of them graduate and continue their practices of refraining and participating with little understanding and/or conviction. Others who live in the residential facilities of the university observe the guidelines of the university so as not to incur penalties. Some of them graduate and cease any semblance of Sabbath observance. And there are students who do not observe Sabbath at all now and do not ever plan to.

Providentially, I was guided by the Holy Spirit to explore this concept with a former colleague who had, since our initial time together, become a professor and coordinator of the religious education program at Andrews University. She was very receptive and supportive so I asked if she would serve as my adviser for this project, unaware that she "has been "recognized for her abiding concern for the spiritual growth of University students" 19

\section{Statement of the Task}

The purpose of this dissertation is to examine a theological issue in ministry, namely, the influence of a spiritual formation course on the perspectives of Sabbath/Sabbathkeeping as a spiritual discipline among African-American Oakwood

\footnotetext{
${ }^{19}$ Patricia Spangler, ed., "Shandelle Henson and Jane Thayer receive J. N. Andrews Medallion," Focus, Spring 2009, 11.
} 
University students. As an appropriate intervention to address this specific ministry challenge, a spiritual formation course has been developed to enable students to identify a holistic understanding and experience of Sabbath/Sabbathkeeping as a spiritual discipline. Another important objective is to provide the tools for students to differentiate between Sabbath/Sabbathkeeping as a spiritual discipline and Sabbath/Sabbathkeeping as propositional truth and to evaluate the significance of the difference. The response to propositional truth in a religious context can often be functional as a condition of salvation rather than relational as the result of intimacy with the Lord of the Sabbath.

\section{Statement of the Problem}

Although most students who attend Oakwood University are self-identified Seventh-day Adventist Christians according to the "Summary of Student Enrollment by SDA Unions and Conferences" as reported in the Oakwood University Fact Book 20082009 , from general observation of their activities, conversations, and attitudes displayed on any given Friday night and/or Saturday (i.e., Sabbath), it would be easy to conclude that many neither enter nor exit their collegiate experience with a holistic understanding or experience of Sabbath and Sabbathkeeping as "a way we can be receptive to God."20

It is safe to assume that they do not view Sabbath/Sabbathkeeping as a spiritual discipline to be offered as a means of "radical abandonment to God in love and equally radical availability to God for others so that in all circumstances and relationships our life

\footnotetext{
${ }^{20}$ Edward Martin Allen, Rest as a Spiritual Discipline: The Meaning and Manner of Sabbath Observance (DMin dissertation, Fuller Theological Seminary, 1991), 35.
} 
becomes one in whom God is present for others."21 Instead, for many students, Sabbath and Sabbathkeeping may primarily be regarded as one of many "general regulations on student conduct" as recorded in the Student Handbook since "by enrolling at Oakwood University, a student signifies his/her support of and willingness to live in accordance with the codes, rules, regulations and objectives of the University and the standards of the Seventh-day Adventist Church." 22 The research question then, for this dissertation project is, How does a spiritual formation course influence the perspectives of African American Oakwood University students on Sabbath and Sabbathkeeping as a spiritual discipline?

\section{Statement of Justification}

Donna Schaper writes, "Sabbath is a way of living not a thing to have or a list to complete." ${ }^{23}$ But far too many Seventh-day Adventist Christians exhibit a "functional versus relational response" ${ }^{\text {,24 }}$ and a "doing versus being approach"25 to Sabbath and Sabbathkeeping, the context by which their lives are informed and out of which their lives flow. This "informational versus formational" ${ }^{26}$ understanding of Sabbath and Sabbathkeeping not only negates the purpose of this special day, but marginalizes the

\footnotetext{
${ }^{2 \mathrm{I}} \mathrm{M}$. Robert Mulholland Jr., The Deeper Journey: The Spirituality of Discovering Your True Self (Downers Grove, IL: InterVarsity Press, 2006), 139.

${ }^{22}$ Division of Student Services of Oakwood College, "Oakwood College Student's Bill of Rights," Student Handbook 2007-2009, 11.

${ }^{23}$ Donna Schaper, Sabbath Keeping (Boston: Cowley Publications, 1999), 8.

${ }^{24}$ Mulholland, Shaped By the Word, 85.

${ }^{25}$ Ibid., 97.

${ }^{26}$ M. Robert Mulholland Jr., Invitation to a Journey: A Road Map for Spiritual Formation (Downers Grove, IL: InterVarsity Press, 1993), 113.
} 
purpose of human beings as well. Additionally, such legalistic orientation leads to an "us against them" reality and to exclusivity and arrogance with regard to those who understand, observe, honor, and/or keep the seventh day of the week like any other day, from a Jewish perspective or have chosen another day of the week as Sabbath.

Psalm 92 provides biblical, theological, historical, sociological, and psychological relevance for this dissertation. In his book, $A$ Love Song for the Sabbath: How to Experience the Joy That God Intended When He Gave Us the Sabbath, Richard Davidson beautifully 'exegetes this psalm and significantly advances the notion that "the Sabbath is not primarily a fact to prove, but a meaning to be discovered, a personal relationship to experience. ${ }^{27}$ If Sabbath were to be understood and experienced in its fullness, the human response to the Sabbath of the Lord and the Lord of the Sabbath would be transformed in the domains of knowing, doing, and being.

Although postmodernity has been characterized by the rejection of authority and absolutes, including organized religion, it is also identified by a dramatically increased interest in spirituality. Over the past twenty-five years there has been a proliferation of articles and books on the general topic of spirituality and a resurgence of interest by Protestants in Christian spiritual formation with considerable attention given to the subject of "Sabbath time," "Sabbath rest," and "Sabbathkeeping."

Although many volumes have been written about Sabbath and Sabbathkeeping by Seventh-day Adventist Christians, unfortunately, not much has been penned on the topic of spiritual formation per se, particularly as it relates to the theological constructs of that

\footnotetext{
${ }^{27}$ Richard M. Davidson, A Love Song for the Sabbath: How to Experience the Joy That God Intended When He Gave Us the Sabbath (Hagerstown, MD: Review and Herald, 1988), 8.
} 
faith community. As a result there is no readily apparent connection between obedience to and observance of the fourth commandment and Sabbath/Sabbathkeeping as a spiritual discipline in the spiritual formation of Seventh-day Adventist Christians. This dissertation, therefore, may eventually become the basis for textbooks in the curricula for theological education in Seventh-day Adventist Christian schools and a handbook for laity and clergy alike.

There is the potential for this study to add two new perspectives to the academic field of applied theology and specifically, spiritual formation and spirituality. The Seventh-day Adventist Christian voice in this discipline is largely missing although the view of the denomination on "the perpetuity of [God's] law" 28 is widely recognized. It is also true that the African-American contribution to this field of study is generally sparse. Therefore, it is possible that this research can serve as an authentic witness of Seventhday Adventist Christian spirituality within a specific cultural context.

\section{Expectations for the Project}

To the extent that the future leaders of the Seventh-day Adventist church become aware of the most identifiable tenet of the church's beliefs as an opportunity for spiritual formation, true Sabbath and Sabbathkeeping can be taught and modeled in denominational institutions and everywhere else as transforming our personal, corporate, and social spirituality. It is my hope that this research will introduce students to the understanding and experience of Sabbath and Sabbathkeeping as an integral dimension of the joyful Christian life.

\footnotetext{
${ }^{28}$ Ministerial Association, Seventh-day Adventists Believe: An Exposition of the Fundamental Beliefs of the Seventh-day Adventist Church (Boise, ID: Pacific Press, 2005), 270.
} 


\section{Delimitations}

Study restrictions. The study was restricted to the two sections of RP131: Spiritual Formation for Ministry. The study used only the instrumentation of a survey utilized as Pre-test and Post-test on the first and last days of instruction. The survey employed both quantitative and qualitative questions.

Study focus. The focus of the study was the influence of spiritual formation course on perspectives of Sabbath and Sabbathkeeping as a spiritual discipline.

Participant limitations. The study was limited to African American students, 18 years of age and older, who gave informed consent and who were enrolled in either RP131-01 or RP131-02.

Time restraints. The study was bounded by the dates of instruction for Spring Semester 2009.

Location. The study was conducted in a classroom in the Department of Religion and Theology (Moseley Complex) at Oakwood University in Huntsville, Alabama.

Translation. All biblical quotations, unless otherwise noted, are from the English Standard Version of the Bible, copyright 2002 by Crossway Bibles, a publishing ministry of Good News Publishers. All rights reserved.

\section{Limitations}

Anticipated inadequacies in regard to the internal validity of results include the size of the sample and the ability to draw descriptive or inferential conclusions from the sample data about a larger group. All of the collected data will be self-reported.

This study is limited to evaluating the influence of a spiritual formation course on the perspectives of Sabbath and Sabbathkeeping as spiritual disciplines among African 
American Oakwood University students during Spring Semester 2009.

The research confines itself to a study of the influence of a spiritual formation course exclusively on the perspectives of Sabbath and Sabbathkeeping as spiritual disciplines and no other spiritual disciplines among African American Oakwood University students during Spring Semester 2009.

It is not possible to separate the influence of the course from other concurrent influences in the lives of the students.

\section{Definition of Terms}

\section{African American}

According to the March 14, 2001, Press Release of the U.S. Census Bureau regarding Questions and Answers for Census 2000 Data on Race, the "Census Bureau complies with the Office of Management and Budget's standards for maintaining, collecting, and presenting data on race, which were revised in October 1997. They generally reflect a social definition of race recognized in this country. They do not conform to any biological, anthropological or genetic criteria. $\$ 29$

"The following definition applies to the 2000 Census only. Black or African American. A person having origins in any of the Black racial groups of Africa. It includes people who indicate their race as 'Black, African Am., or Negro,' or provide

\footnotetext{
${ }^{29}$ "Questions and Answers for Census 2000 Data on Race," U.S. Census Bureau, http:/www .census.gov/Press-Release/www/2001/raceqandas.hml (accessed June 16, 2009).
} 
written entries such as African American, Afro American, Kenyan, Nigerian, or Haitian."30

For the purposes of this project dissertation, the term "African American" should be understood as defined by the U.S. Census Bureau.

\section{Oakwood University}

Located in Huntsville, Alabama, Oakwood University is one of fourteen Seventhday Adventist institutions of higher learning in the United States and Canada. It is an accredited, coeducational, liberal arts university operated by the General Conference of Seventh-day Adventist Christians.

Established in 1896 as Oakwood Industrial School in delayed response to the March 21, 1881, address by Ellen G. White to the General Conference Session at Battle Creek, Michigan, this institution was denominationally recognized as partial fulfillment of "Our Duty to the Colored People" as her speech was entitled. ${ }^{31}$

"Oakwood ... has been consistently listed among the 'top institutions of higher learning in the Southern region' by U.S. News and World Report in its annual issue rating college and universities in America."32

The mission statement of this institution reads, "Oakwood University, a historically Black Seventh-day Adventist institution of higher learning, provides quality

\footnotetext{
30"Race and ethnicity in the United States Census," Wikipedia, http://en.wikipedia.org/wiki/ African-American_(U.S. Census) (accessed June 16, 2009).,

${ }^{31}$ Benjamin J. Baker, A Place Called Oakwood-Inspired Counsel: A Comprehensive Compilation of Ellen G. White Statements on the Oakwood Educational Institution (Hagerstown, MD: Review and Herald, 2007), 164.

${ }^{32}$ Oakwood University, Office of Academic Affairs, Oakwood University Bulletin 2007-2009 (Huntsville, AL: Oakwood University, 2007), 3.
} 
Christian education that emphasizes academic excellence; promotes harmonious development of mind, body and spirit and prepares leaders in service for God and humanity." 33

"Cultural diversity abounds on the campus of Oakwood University, where the average enrollment of over 1,800 students comes from as many as forty states and thirty countries. ${ }^{34}$

\section{Sabbath}

Although definitions of Sabbath throughout history seem to proliferate, for the purpose of this dissertation, Sabbath begins at sunset on Friday and continues until sunset on Saturday.

\section{Sabbathkeeping}

While the fourth commandment specifically enjoins the human family to refrain from working on the seventh day, there is much more involved in Sabbathkeeping. Commenting on distortions of Sabbathkeeping prior to the birth of Jesus, Gregory Nelson, former senior pastor of the College View Church in Lincoln, Nebraska, observes the following:

No wonder God is so hard on the Israelites in the Old Testament. Their religious life, the spirituality; their Sabbath keeping, had degenerated into a list of do's and don'ts performed one day out of the week, the Sabbath. Notice what God says to them in Isaiah $58 .^{35}$

${ }^{33}$ Oakwood University, Oakwood University Bulletin 2007-2009; 8.

${ }^{34}$ Ibid.

${ }^{35}$ Gregory P. Nelson, A Touch of Heaven: Finding New Meaning in Sabbath Rest (Nampa, ID: Pacific Press, 1999), 100. 
True Sabbath keeping, then, is a lifestyle, deliberate attempts to bring the qualities of heaven to this earth now, 'playing heaven,' where we enjoy the opportunity to imitate our heavenly Father and the values important to Him. So what values does this passage say are important to Him? People, justice, peace, equality, feeding-clothinghousing the less fortunate, environment, family, relationships. Active concern about these issues, says God, and applying His values to them is true Sabbath keeping. ${ }^{36}$

\section{Seventh-day Adventist}

The Seventh-day Adventist Church (commonly abbreviated "Adventist") is a Christian denomination which is distinguished by its observance of Saturday, the original seventh day of the Judeo-Christian week, as the Sabbath, and by its emphasis on the imminent second coming of Jesus. It is the eighth largest international body of Christians. The denomination grew out of the Millerite movement in the United States during the middle part of the $19^{\text {th }}$ century and was formally established in 1863. Among its founders was Ellen G. White, whose extensive writings are still held in high regard by Seventh-day Adventists today. ${ }^{37}$

From the official website of the Seventh-day Adventist Church, a definition of a Seventh-day Adventist Christian is implied in its mission statement which includes its mission, its method, and its vision.

The mission of the Seventh-day Adventist Church is to proclaim to all peoples the everlasting gospel of God's love in the context of the three angels messages of Revelation 14:6-12 and as revealed in the life, death, resurrection, and high priestly ministry of Jesus Christ, leading them to accept Jesus as personal Saviour and Lord and to unite with His remnant church; and to nurture believers as disciples in preparation for His soon return. ${ }^{38}$

\section{Spiritual Discipline}

The Upper Room is a United Methodist-related ecumenical organization dedicated to providing resources for spiritual growth and spiritual leadership. One such

\footnotetext{
${ }^{36}$ Nelson, A Touch of Heaven, 102.

37" What is a Seventh-day Adventist," Wikipedia, http://en.wikipedia.org/wiki/SeventhdayAdventist (accessed July 21, 2009).

38، Adventist Beliefs, Mission Statement of the Seventh-day Adventist Church," http://www .adventist.org/beliefs/statements/main_statl.html (accessed July 21,2009).
} 
resource is the Dictionary of Christian Spiritual Formation which offers the following

definitions and explanations.

In Christian spirituality, a discipline is a rule of life or a set pattern of living intended to facilitate spiritual growth and Christian community. Spiritual disciplines are concerned with our lifestyle or our practice of faith and faithful living. Among these patterns of living are some called the classical spiritual disciplines because they have biblical roots and because through the various ages and renewal movements of the church, Christians have tested them and found them central to experiential Christianity and growth toward spiritual maturity. Richard Foster's Celebration of Discipline ... divides them into three categories: (1) inward disciplines of meditation, prayer, fasting and study or spiritual reading; (2) outward disciplines of social mercy or service, solitude, simplicity and submission; and (3) corporate disciplines of worship, guidance or spiritual direction, confession, and jubilee or celebration.

Spiritual disciplines involve more than just psychological change. Their concern is total and complete graced transformation and healing. ... By themselves the spiritual disciplines cannot change us, but they offer a way to participate in the grace that is available for spiritual growth. That is why John Wesley called them the "means of grace." They are tools or conduits through which grace is given that alone can transform the heart. In this sense, the spiritual disciplines are relational expressions of our openness to God, of our longing for the life of God, of our commitment to the covenant, and our belief in the promise of complete transformation or sanctification. ${ }^{39}$

But for the purpose of this project, I have chosen the definition of spiritual discipline as "the means to godliness" ${ }^{\text {"40 }}$ based on my understanding and appreciation of 1 Timothy 4:7 (NASB) which reads, "Discipline yourself for the purpose of godliness."

\section{Spiritual Formation}

Like "spiritual discipline," spiritual formation has been understood in a variety of ways by other Christians. Baptist theologian Reggie McNeal refers to it as "heart

\footnotetext{
${ }^{39}$ Keith Beasley-Topliffe, ed., The Upper Room Dictionary of Christian Spiritual Formation (Nashville, TN: Upper Room Books, 2003), 84.

${ }^{40}$ Donald S. Whitney, Spiritual Disciplines for the Christian Life (Colorado Springs, CO: NavPress, 1991), 15.
} 
shaping." Quaker teacher and activist Parker Palmer calls it "soul work done in community. ${ }^{24}$ Catholic scholar and spiritual director Henri J. M. Nouwen explains it as "the ever increasing capacity to live a spiritual life from the heart." ${ }^{, 43}$ Renowned author Richard Foster asserts that it's what "occurs in the dynamic exercise of human choice in response to divine purposes. ${ }^{, 44}$ But for the purposes of this research I have chosen the definition of Methodist seminary professor of New Testament Interpretation, M. Robert Mulholland: "the process of being conformed to the image of Christ for the sake of others. ${ }^{45}$ This definition was chosen precisely because of its intentional inclusion of the mission to strengthen thy brethren when thou art converted (Luke 22:32 KJV).

\section{Students}

The admissions standards for the school are stated in the university bulletin as follows:

Oakwood ... welcomes applicants regardless of race, color, nationality, ethnicity, sex or physical challenges. Students who meet the academic requirements and character expectations of the [university] and are willing to adjust to and to be comfortable within its religious, social and cultural atmosphere may be admitted subject to available space.

Oakwood ... is sponsored and financed primarily by the Seventh-day Adventist Church, of which the majority of its students are members. Although religious affiliation is not a requirement for admission, all students are expected to abide by the

\footnotetext{
${ }^{41}$ Reggie McNeal, $A$ Work of Heart: Understanding How God Shapes Spiritual Leaders (San Francisco: Jossey-Bass, 2000), xiii.

${ }^{42}$ Parker Palmer, A Hidden Wholeness: The Journey Toward an Undivided Life (San Francisco: Jossey-Bass, 2004), 57.

${ }^{43}$ Henri J. M. Nouwen, Spiritual Direction: Wisdom for the Long Walk of Faith (New York: HarperCollins, 2006), xv. 2005), 2.

${ }^{44}$ Richard J. Foster, The Renovare Spiritual Formation Bible (San Francisco: HarperSanFrancisco,

${ }^{45}$ Mulholland, Shaped by the Word, 25.
} 
policies and standards of the [university] as outlined in the ... Bulletin and in the Student Handbook. Applicants are required to sign a pledge agreeing to the Code of Student Conduct prior to completing registration. ${ }^{46}$

According to the Office of Institutional Effectiveness at Oakwood University, during Fall Semester 2007, 1,615 of the 1,824 students were African American which is $89 \%$ of the student body. ${ }^{47}$ During that same period of time, 1,386 of the 1,824 students were recognized as Seventh-day Adventist Christians by their Unions and Conferences which is $76 \%$ of students enrolled. ${ }^{48}$ During Spring Semester $2008,1,532$ of the 1,734 students were African American which is $88 \%$ of the student body. ${ }^{49}$ And for that time period, 1,337 of the 1,734 students enrolled were identified as Seventh-day Adventist Christians by their Unions and Conferences which is $77 \%$ of the student population. ${ }^{50}$

\section{Methodology}

1. As part of the research for this project I used a pre-test, post-test methodology to determine the cognitive, behavioral, and affective realms of Sabbath and Sabbathkeeping among students enrolled in RP131: Spiritual Formation for Ministry. The intervention was the aforementioned semester-long course which included weekly reading reports, weekly reports of the practice of the spiritual disciplines, reflection papers, resource files, a Sabbath service at a local synagogue, a weekend retreat

${ }^{46}$ Oakwood University, Oakwood University Bulletin 2007-2009, 11.

${ }^{47}$ Oakwood University, Fact Book 2007-2008 (Huntsville, AL: Office of Institutional Effectiveness, 2008), 77.

${ }^{48}$ Ibid., 95.

${ }^{49}$ Ibid., 99 .

${ }^{50}$ Ibid., 111. 
emphasizing God's special presence on Sabbath, and retreat evaluations.

2. I reflected on the Old and New Testaments as well as relevant passages from the writings of Ellen G. White and biblical scholars/theologians regarding Sabbath and Sabbathkeeping in order to provide the foundations for this project.

3. I reviewed current literature on religious/theological education philosophy and curriculum in colleges and universities (in general and in Seventh-day Adventist institutions); postmodernism; spiritual formation (including spirituality and spiritual development within the context of developmental theories); biblical and theological moorings for spiritual formation; spiritual formation courses in religious/theological education (in general and in Seventh-day Adventist college and universities); the relationship of spiritual formation and/or spiritual formation course to university students; the relationship of spiritual formation and/or spiritual formation courses to African American university students; the influence of spiritual disciplines; the influence of spiritual disciplines on university students; the influence of spiritual disciplines on African American university students; the influence of the spiritual discipline of Sabbath/Sabbathkeeping; and the influence of the spiritual discipline of Sabbath and Sabbathkeeping on African American university students. The scholarship is these areas shaped and informed my research in both widening and narrowing the aperture of the lens through which I constructed the intervention to be implemented to examine and address a theological issue in ministry.

4. The details of the research methodology and implementation are described in chapter 4. Outcomes and evaluations are presented in chapter 5 and conclusions and recommendations are summarized in chapter 6 . 
5. Again, the purpose of this dissertation was to examine a theological issue in ministry, namely, the influence of a spiritual formation course on the perspectives of Sabbath/Sabbathkeeping as a spiritual discipline among African-American Oakwood University students. Another important objective was to provide the means by which students would be able to differentiate between Sabbath/Sabbathkeeping as a spiritual discipline and Sabbath/Sabbathkeeping as propositional truth and to evaluate the significance of the difference. Details of the course and the survey instrument are given in chapter 5 .

\section{Summary of the Chapters}

Chapter 1: "Introduction" contains my personal history, statement of the task, statement of the problem, statement of justification, expectations for the project, delimitations, limitations, definition of terms, methodology, and summary of the chapters.

Chapter 2: "A Theology of Sabbath and Sabbathkeeping" is a descriptive and "constructive theological essay that identifies the theological question that is central to the task of this project," n1 namely, "how does a spiritual formation course influence the perspectives of African American Oakwood University students on Sabbath and Sabbathkeeping as a spiritual discipline?" "This chapter enters into conversation with the Bible and the Spirit of Prophecy through the lens of a particular theological approach

\footnotetext{
${ }^{51}$ Kenley D. Hall, "Guidelines for Doctor of Ministry Projects," (Berrien Springs, MI: Andrews University Seventh-day Adventist Theological Seminary, 2009), 17.
} 
(biblical theology) and constructs an answering biblical theology to serve as the theological foundation for the project." 52

Chapter 3: "Literature Review of Issues Related to Sabbath and Sabbathkeeping" incorporates "an introduction that establishes an appropriate context for reviewing literature, defines and justifies the scope of the review, and provides a roadmap for the progression of the chapter. ${ }^{, 53}$ It addresses the relevance and currency of the literature to the topic while allowing "the researchers whose works are being reviewed to be put into conversation with each other and contrasted with each other." 54

Chapter 4: "Methodology and Implementation Narrative" "begins with an introduction followed by a profile of the ministry context that relates specifically to the task of the project. A concise definition is given of the research methodology employed, the interpretation of data and the conclusions drawn from the data. An intervention is developed that builds upon the theological foundation, the literature review, and the research methodology. A narrative of the precise chronological implementation of the intervention is given. And the chapter ends with a conclusion that reiterates the main points and acknowledges directions for further research and reflection." 55

Chapter 5: "Outcomes and Evaluation" comprises an introduction and "a description of the research methodology employed, the interpretation of the data, and the conclusions drawn from the data. Outcomes of the intervention are examined that are

\footnotetext{
${ }^{52}$ Hall, "Guidelines for Doctor of Ministry Projects," 17.

${ }^{53}$ Ibid., 21.

${ }^{54}$ Ibid., 22.

${ }^{55}$ Ibid., 25-26.
} 
measurable by the research methodology employed.

Chapter 6: "Summary, Conclusions and Recommendations" includes a "concise summary of the project," $\$ 66$ "a concise recap of all the conclusions that have been drawn through each of the chapters that culminate in final overarching conclusions,",57 reiterating the main points and explaining the findings, and "a concise list of recommendations that detail further actions that need to be taken or research done in the area of this project," $" 58$ acknowledging directions for further research and reflection." $" 59$

The appendices will embody retreat evaluations, reflection papers, resource files, photographs, and testimonial letters grouped into individual appendices. “An appendix letter and title appear at the top of the first page of each appendix."

The bibliography includes "all references cited [and researched] in alphabetical order." ${ }^{\text {61 }}$ The Vita shall be a one-page summary of my educational and employment history.

\footnotetext{
${ }^{56} \mathrm{Hall}$, "Guidelines for Doctor of Ministry Projects," 30.

${ }^{57}$ Ibid.

${ }^{58}$ Ibid.

${ }^{59}$ Ibid., 28-29.

${ }^{60}$ Ibid., 32.

${ }^{61}$ Ibid., 33.
} 


\section{CHAPTER 2}

\section{BIBLICAL/THEOLOGICAL FOUNDATIONS}

\section{Introduction}

As this section constitutes the Normative Task of this research endeavor, the biblical rationale and theological perspectives for Sabbath observance will now be explored. The Normative Task is the aspect of the spiral that asks the most critical questions and requires the most honest responses. Therefore, hermeneutical principles will be addressed as necessary considerations in the process to accurately discover biblical evidence for Sabbath observance; biblical descriptions and significance of Sabbath observance; and biblical indicators of the universal and permanent applicability of Sabbath observance.

After an examination of scriptural content and context for Sabbath observance from the Pentateuch, historical literature, Psalms, prophets, Gospels, Acts and epistles, an overview of the theological perspectives of selected Seventh-day Adventist Christian biblical scholars and authors on Sabbath observance, based on the same biblical sources, will ensue. The chapter will end with a summary and conclusions.

\section{Hermeneutical Considerations}

Grant R. Osborne begins his comprehensive volume on biblical interpretation by acknowledging the challenge to the traditional definition of hermeneutics as "that science 
which delineates principles or methods for interpreting an individual author's meaning." He points to "the tendency in many circles to restrict the term to an elucidation of a text's present meaning rather than of its original intent." ${ }^{2}$ He continues to set the stage for understanding how to properly interpret a text as follows:

- I will argue that the original meaning is a legitimate, even necessary, concern and that hermeneutics encompasses both what it meant and what it means. I would even oppose the practice today of using "exegesis" for the study of the text's meaning and "hermeneutics" for its significance. Rather, hermeneutics is the overall term while exegesis and "contextualization" (the cross-cultural communication of a text's significance for today) are the two aspects of the larger task. ${ }^{3}$

Osborne notes that biblical interpretation entails "a spiral from the text to context, from its original meaning to its contextualization or significance for the church today."

Many readers, even teachers and preachers, are prone to overlook the setting of a phrase and the exact meaning of a word. A reader who casts his eye on a line of scripture and accepts what it "seems to mean" is dealing in astrology or pre-Copernican astronomy rather than in the present wonder of heavenly truth. Truth depends, not alone on accuracy of meaning, but on its total setting - in what a word or phrase meant for its original speaker in the original time and occasion. $^{5}$

I have chosen the historical-grammatical method of biblical interpretation for this chapter along the lines of Osborne's hermeneutical approach.

Evidence, descriptions, and indicators of universal and permanent applicability of

Sabbath observance require proper attention to the many elements of the biblical text.

${ }^{1}$ Grant R. Osborne, The Hermeneutical Spiral: A Comprehensive Introduction to Biblical Interpretation (Downers Grove, IL: InterVarsity Press, 1991), 5.

${ }^{2}$ Ibid.

${ }^{3}$ Ibid.

${ }^{4}$ Ibid., 6.

${ }^{5}$ George A. Buttrick, "How to Use The Interpreter's Bible," The Interpreter's Bible, vol. 1 (Nashville, TN: Abingdon Press, 1952), xviii. 


\section{Biblical Evidence for Sabbath Observance}

\section{Old Testament Evidence of Sabbath Observance}

In this section evidence from the Pentateuch, the historical and prophetic books, as well as the wisdom literature and psalms will be presented to provide the foundation for the biblical rationale of seventh-day Sabbath observance. Gerhard F. Hasel asserts that " no other part of the Bible has the breadth, depth, and height of ideas, themes and motifs pertaining to the Sabbath as does the Pentateuch."

Hasel, along with W. G. C. Murdoch, posit that "the emphasis on the Sabbath voiced by the writing prophets and inspired writers of the historical literature is rooted in a deep-seated covenant conception in which Yahweh is the covenant Lord and Israel His covenant people" as established in the Pentateuch. Finally, Richard Davidson addresses and remedies the exclusion or meager treatment of "the Old Testament hymnic/wisdom literature in previous scholarly studies which present a biblical theology of the Sabbath", in his research on this subject.

\section{Evidence of Sabbath Observance from the Pentateuch}

"In the beginning ..." So commences the biblical exposition on the creation of "

${ }^{6}$ Gerhard F. Hasel, "The Sabbath in the Pentateuch," in The Sabbath in Scripture and History, ed: Kenneth A. Strand (Washington, DC: Review and Herald, 1982), 21. (See also Mathilde Frey, The Sabbath in the Pentateuch: an exegetical and theological study, Berrien Springs, Michigan: Andrews University, Seventh-day Adventist Theological Seminary dissertation, 2011)

${ }^{7}$ Gerhard F. Hasel and W. G. C. Murdoch, "The Sabbath in the Prophetic and Historical Literature of the Old Testament," in The Sabbath in Scripture and History, ed. Kenneth A. Strand (Washington, DC: Review and Herald, 1982), 44.

${ }^{8}$ Richard M. Davidson, “The Sabbath in the Old Testament Psalms and Wisdom Literature," presentation to the Biblical Research Institute Committee, Silver Spring, Maryland, 2008, 1. 
the world. Chapters one and two of the first book of the Bible, appropriately entitled "Genesis," record the origins of all life. According to the scriptural account, after speaking light into existence and separating the waters to create the sky, the seas, and the land, God caused vegetation to come into being and grow. He then separated the day from night with the introduction of the sun, moon, and stars. Next He made fish and fowl followed by animals of every species and deemed all of His handiwork to be "good."

But on the sixth day God departed from His pattern and decided to make 'âdâm (adam) - the Hebrew word that designates-humanity as differing from divinity as opposed to delineating maleness from femaleness-"in our image, after our likeness" (Genesis 1:26) and gave them dominion over everything previously made. At this point, however, God considered His creative work to be "very good" which seems to be a very telling ending to the first chapter.

Then the story resumes in the first three verses of chapter 2. "Thus the heavens and the earth were finished, and all the host of them. And on the seventh day God finished his work that he had done, and he rested on the seventh day from all his work that He had done. So God blessed the seventh day and made it holy, because on it he rested from all his work that he had done in creation" (Genesis 2:1-3).

Thus the Sabbath was established at creation. Although Genesis 2:2-3 contains no specific Sabbath command, as noted by Skip MacCarty, the creation account underscores the special nature of the seventh day in three ways.

(1) The seventh day is the very first thing the Bible records being "made holy," sanctified by God ... (2) In Genesis 1:1-2:3, the first six days of creation are each mentioned once, while the seventh day is mentioned three times: "By the seventh day God had finished the work," "on the seventh day he rested," "God blessed the seventh day and made it holy." The repetition emphasizes the importance of the day in the divine economy. (3) Genesis 2:1-3 avoids the phrase "there was evening, and there 
was morning," which was used in conjunction with the other six days of creation to conclude the activities of the day and as a transition to the creating activities of the following day. The seventh day breaks that pattern. ${ }^{9}$

Exodus 16:23-29 recounts God's provision for the Israelites by sending manna from heaven on every day of the week but the seventh. They were instructed not to gather more than one day's supply except on the sixth day when they were to gather enough for two days. It was explained to them that they would find no manna to gather on the seventh day of the week because it was to be a day of rest, "a holy Sabbath to the LORD" (v. 23). But, irrespective of God's command, some of the people went out to gather manna on the seventh day anyway, prompting God to ask "How long will you refuse to keep my commandments and my laws?" (v. 28). As stated by Kenneth Strand, "This wording gives the distinct impression that the Sabbath was already known to the Israelites. $" 10$

Gerhard Hasel summarizes the major ideas about the Sabbath in Exodus 16 as follows:

1. The "sixth day" prepares for the Sabbath...

2. The Sabbath is the day following the sixth day...

3. A divine commandment enjoined the keeping of the Sabbath.

4. The Sabbath is holy...

5. The Sabbath is a day of rest...

6. The Sabbath is a "sabbath feast"...

7. The Sabbath is a testing ground of man's relationship with God... ${ }^{11}$

The popular tendency to limit Sabbath and Sabbathkeeping to Judaism often finds

\footnotetext{
${ }^{9}$ Skip MacCarty, "The Seventh-day Sabbath," in Perspectives on the Sabbath, ed. Christopher Donato (Nashville: B\&H Publishing Group, 2011), 13-14.

${ }^{10}$ Kenneth A. Strand, "The Sabbath," in Handbook of Seventh-day Adventist Theology, ed. Raoul Dederen (Hagerstown, MD: Review and Herald, 2000), 496.

${ }^{11}$ Hasel, "The Sabbath in the Pentateuch," 27.
} 
its origins in the misinterpretation of Exodus 20:8-11 as the first reference to the Sabbath.

Remember the Sabbath day, to keep it holy. Six days you shall labor and do all your work, but the seventh day is a Sabbath to the LORD your God. On it you shall not do any work, you, or your son, or your daughter, your male. servant, or your female servant, or your livestock, or the sojourner who is within your gates. For in six days the LORD made heaven and earth, the sea and all that is in them, and rested on the seventh day. Therefore the LORD blessed the Sabbath day and made it holy.

Hasel notes that "the Sabbath commandment (Exodus 20:8-11) consists of fiftyfive Hebrew words and is the longest of the Ten Commandments." ${ }^{12}$ He also calls attention to the careful construction of the Sabbath commandment.

A. Introduction Remember the Sabbath day to keep it holy. (v. 8, RSV) $B^{1}$ Command Six days you shall labor and do all your work; (v.9)

$C^{1}$ Motivation but the seventh day is a sabbath to the LORD your God; (v.10a)

$B^{2}$ Command in it you shall not do any work, you, or your son, or ... (v. 10b)

$\mathrm{C}^{2}$ Motivation for in six days the LORD made heaven and earth, the sea,... rested (v.11a)

D Conclusion

therefore the LORD blessed the sabbath day and made it holy. $(\mathrm{v} .11 \mathrm{~b})^{13}$

The Theological Lexicon of the Old Testament contends that one definition of the

Hebrew word zâkar, translated "remember," is "to demonstrate covenant loyalty."14

In Exodus 31:12-17 new elements of the Sabbath are introduced. The text reads:

And the LORD said to Moses, "You are to speak to the people of Israel and say, 'Above all you shall keep my Sabbaths, for this is a sign between me and you throughout your generations, that you may know that I, the LORD, sanctify you. You shall keep the Sabbath because it is holy for you. Everyone who profanes it shall be put to death. Whoever does any work on it, that soul shall be cut off from among his people. Six days shall work be done, but the seventh day is a Sabbath of solemn rest, holy to the LORD. Whoever does any work on the Sabbath day shall be put the death. Therefore the

${ }^{12} \mathrm{Hasel}$, "The Sabbath in the Pentateuch," 28.

${ }^{13}$ Ibid., 29.

${ }^{14}$ Emst Jenni and Claus Westerman, Theological Lexicon of the Old Testament, trans. Mark E. Biddle (Peabody, MA: Hendrickson Publishers, 1997), 1:255. 
people of Israel shall keep the Sabbath, observing the Sabbath throughout their generations, as a covenant forever. It is a sign forever between me and the people of Israel that in six days the LORD made heaven and earth, and on the seventh day he rested and was refreshed."

Here the Sabbath is identified as a sign of God's sanctifying His people and as a sign to always remind His people that $\mathrm{He}$ is their Creator. Sabbathkeeping, as a sign, was intended to function as the continual means of conveying benefits beyond itself. The Sabbath is also stipulated as a lasting or perpetual covenant to be celebrated for the generations to come.

The Hebrew rendering of Exodus 23:12 employs three different words to express the idea of rest. The text reads, "Six days you shall do your work, but on the seventh day you shall rest; that your ox and your ass may have rest and the son of your bondmaid, and the alien, may be refreshed." Again, Dr. Strand is helpful in supplying definition.

For the "rest" commanded to the Israelites in covenant relationship with God, the verb is šabat, whereas for the beasts of burden, the type of rest is simply nuah. And for the "son of your bondmaid and the alien," the niphal imperfect of napăs, "to refresh" is used. This Hebrew word does not necessarily imply recovery from weariness, though that element may be included; rather it suggests an enhancement in quality of life or the pleasure of rest from work that has been accomplished well. ${ }^{15}$

Mathilde Frey articulates the three primary components in her study of the

Sabbath commandment in the book of the covenants.

The purpose of this study is to investigate the elements which suggest the interconnection between Exod 23:12 and Gen 21, i.e., the motif of the God who hears the cry of the afflicted and oppressed, as well as specific Hebrew terms which indicate specific intertextual links. Finally, I will highlight a new dimension of the Sabbath commandment which originates in the hope expressed by Lamech at the birth of his son Noah in Gen 5:29, thus

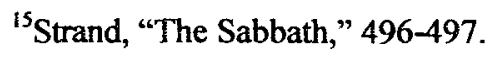


implementing the Sabbath commandment in Noah's covenantal history. ${ }^{16}$

The Hebrew terms in Exodus 23:12 indicating ceasing, resting and refreshing or breathing had great importance for those most disenfranchised: not just hard-working animals, servants (male and female), and strangers as stated in both renderings of the Decalogue, but the reference to the "son of your female slave" is particular significance. Frey notes that "children born in slavery are defined as sons and daughters of the male servant, not the female servant (Exod 21:4) $)^{\text {"17 }}$ and that this expression is first used in Genesis 21:10, 13 referring to Ishmael (which means "God hears"), the son of Hagar, servant of Sarah, which "stresses the motif of God's compassionate listening to the cry of the one who is about to die." 18

Frey also points to Exodus 23:12 as the only Sabbath text that uses a Hebrew noun for work that provides a new perception of it in contrast to its usual negative connotation. She states that "the positive perspective of weekly' work then comes by teaching and declaring the laws of the Torah (Exod 18:20), which promotes Sabbath observance as rest (נוח) and refreshment (נפשל) (Exod 23:12)."

Perceived in this way, just as God declared his creation as very good at the end of the six days of the first week leading up to the blessing and sanctification of the seventh day, the Sabbath commandment points to the work of the six days of the week as "the fruit of your hands" (Exod 23:16) or good and fruitful work, which leads to celebration on the Sabbath. ${ }^{20}$

\footnotetext{
${ }^{16}$ Mathilde Frey, "The Sabbath Commandment in the Book of the Covenant: Ethics on Behalf of the Outcast," Journal of Asia Adventist Seminary 9, no. 1 (2006): 4.

${ }^{17}$ Tbid., 6.

${ }^{18}$ Ibid., 7

${ }^{19}$ Mathilde Frey, "The Sabbath in the Pentateuch: An Exegetical and Theological Study" (DMin dissertation, Andrews University, 2011), 182-183.

${ }^{20}$ lbid., 183.
} 
Exodus $34: 21$ is a reminder of "the great sanctity with which God ... invested the [seventh] day" ${ }^{21}$ because it states that even during the seasons of greatest financial import in that context, no work was to be done on the Sabbath.

Likewise, the following passage asserts the priority of Sabbath observance even in the midst of constructing the tabernacle.

Moses assembled all the congregation of the people of Israel and said to them, "These are the things that the LORD has commanded you to do. Six days work shall be done, but on the seventh day you shall have a Sabbath of solemn rest, holy to the LORD. Whoever does any work on it shall be put to death. You shall kindle no fire in all your dwelling places on the Sabbath day" (Exod 35:1-3).

Only six of the many texts found in Leviticus that include the term shabbät and shabbātôn refer to the weekly Sabbath. The remaining verses refer to the annual Day of Atonement and to the sabbatical year. ${ }^{22}$ Leviticus 19:3, Leviticus 19:30, and Leviticus 26:2 all contain the imperative to observe the LORD's Sabbaths along with the command to honor one's parents in the first instance and to have reverence for the LORD's sanctuary in the other two. In Leviticus 23:3 Sabbath is identified as both a day of solemn rest and a day of sacred assembly or holy convocation. As God instructs Moses regarding the Feast of Tabernacles in Leviticus 23:33-43, He refers to offerings "besides the LORD's Sabbaths" in verse 38. Verses 5-8 of chapter 24 contain further instruction for Moses with regard to the bread such that "every Sabbath day Aaron shall arrange it before the LORD regularly" (v. 8)

While the people of Israel were in the wilderness, they found a man gathering sticks on the Sabbath day. And those who found him gathering sticks brought him to Moses and Aaron and to all the congregation. They put in custody,

\footnotetext{
${ }^{21}$ Frey, "The Sabbath in the Pentateuch," 497.

${ }^{22}$ Strand, "The Sabbath," 497.
} 
because it had not been made clear what should be done to him. And the LORD said to Moses, "The man shall be put to death; all the congregation shall stone him with stones outside the camp." And all the congregation brought him outside the camp and stoned him to death with stones, as the LORD commanded Moses (Num 15:32-36).

In his dissertation on Pentateuchal sacred times, H. Ross Cole concludes that the text above "presents the Sabbath as an institution that applies to the wilderness prior to Israel's possession of her land"23 in the example of flagrant disobedience to Sabbath observance precepts and the fatal consequences.

Numbers 28:9-10, the only other passage in this book that refers to the weekly Sabbaths, specifies the special offerings to be sacrificed along with the regular ones. "On the Sabbath day, two male lambs a year old without blemish, and two tenths of an ephah of fine flour for a grain offering, mixed with oil, and its drink offering: this is the burnt offering of every Sabbath, besides the regular burnt offering and its drink offering."

The last reference to the weekly Sabbaths in the Pentateuch is located in last book of Moses where he repeats the fourth commandment found in Exodus 20:8-11 with one significant exception. "You shall remember that you were a slave in the land of Egypt, and the LORD your God brought you out from there with a mighty hand and an outstretched arm. Therefore the LORD your God commanded you to keep the Sabbath day" (Deut 5:15).

Whereas the first rendering of the Sabbath commandment emphasized God as Creator, the second highlights His role as Liberator, Deliverer or Redeemer. Sakae Kubo notes that "from the experiential point of view, we encounter God as Redeemer before we

\footnotetext{
${ }^{23} \mathrm{H}$. Ross Cole, "The Sacred Times Prescribed in the Pentateuch: Old Testament Indicators of the Extent of Their Applicability" (PhD dissertation, Andrews University, 1996), 144.
} 
recognize Him as Creator. One merges naturally into the other. ${ }^{24}$

Both articulations of the Sabbath command mandate an unprecedented equality in that all are to rest on the seventh day but the reiteration requires remembering one's own prior enslavement. And in so doing there is a nuance of fellowship inferred as well. As Sakae Kubo states, "God is our example here. He rested to fellowship with men." 25

\section{Evidence of Sabbath Observance from the Historical and Prophetic Books}

Evidence from eleventh and tenth century references

Chapter 9 of 1 Chronicles announces that God's people, who had been in Babylonian captivity due to their disobedience, were assigned a variety of responsibilities by David and Samuel as they began "to dwell again in their possessions in their cities" (v. 2). One responsibility was the preparation of the showbread every Sabbath (v. 32).

Then chapters 23-28 outline David's instructions and plans for the temple. Job descriptions for Levites, priests, singers, gatekeepers, treasurers, army divisions, officers of the tribes, the king's overseers, and other officials are set forth. And here in David's old age, David is careful to underscore the importance of the burnt offering to be "offered to the LORD on Sabbaths, new moons and feast days" (1 Chronicles 23:31). Kenneth Strand notes the following: "The same days are mentioned in Solomon's communication with Hiram of Tyre for help in building the Temple (2 Chronicles 2:4). After the Temple

\footnotetext{
${ }^{24}$ Sakae Kubo, God Meets Man: A Theology of the Sabbath and the Second Advent (Nashville, TN: Southern Publishing Association, 1978), 45.

${ }^{25}$ Ibid., 29.
} 
was built and dedicated, Solomon offered the required offerings on those same days ( 2 Chronicles 8:13). ${ }^{, 26}$

Evidence from ninth century references

In his introduction to 2 Kings, Spiros Zodhiates notes how "in painful detail this book narrates the tragic events of the divided kingdom until Israel's fall in 722 B.C. and Judah's captivity in 586 B.C., 27

The weekly Sabbath is mentioned twice in 2 Kings in unique ways that indicate its prominence in post-Pentateuchal times. In 2 Kings 4:18-37 a distraught Shunamite woman prepared to "quickly go to the man of God and come back again" (v. 22) after her only son died unexpectedly. Her husband questioned her going to see Elisha since it is neither the Sabbath nor the New Moon, indicating not only the observance of the weekly Sabbath but that travel to visit spiritual leaders on the Sabbath was not prohibited.

In the second instance Jehoiada, the high priest, arranged a brilliant overturn of power whereby seven-year-old Joash was made king on the Sabbath as recorded in 2 Kings 11:4-20 and 2 Chronicles 23:1-11. His coronation included being presented with a copy of the covenant.

Evidence from eighth century references

The expression "the covert for the Sabbath" in the King James Version of the Bible or "the Sabbath canopy" as translated in the New International Version of 2 Kings

${ }^{26}$ Strand, "The Sabbath," 499.

${ }^{27}$ Spiros Zodhiates, ed., The Hebrew-Greek Key Study Bible (Chattanooga, TN: AMG Publishers, 1984), 492. 
16:18 is generally unclear. But in Prophets and Kings, Ellen White provides the context for some understanding of its removal by King Ahaz.

As the apostate king neared the end of his reign, he caused the doors of the temple to be closed. The sacred services were interrupted. No longer were the candlesticks kept burning before the altar. No longer were offerings made for the sins of the people. No longer did sweet incense ascend on high at the time of the morning and evening sacrifices. Deserting the courts of the house of God and locking fast its doors, the inhabitants of the godless city boldly set up altars for the worship of heathen deities on the street corners throughout Jerusalem. ${ }^{28}$

She goes on to convey that a faithful few remained despite the closing of the sanctuary and then she quotes Isaiah 8:14 which refers to the LORD as "a sanctuary" for them. It is likely that this comforting reference would have stirred up beautiful images and fond memories of Sabbath worship in that place of worship to which they no longer had access as they continued to honor the Lord of the Sabbath and the weekly time He had blessed.

Another evidence for Sabbath observance in the Old Testament during this period appears in 2 Chronicles 31:3. "The contribution of the king [Hezekiah, the great Reformer] from his own possessions was for the...burnt offerings for the Sabbaths, the new moons, and the appointed feasts, as it is written in the Law of the LORD."

Amos, "a champion of the underprivileged, the poor, and the oppressed,"29 chastised the greed of the Northern Kingdom that sought to hasten the end of the Sabbath to extend its profit margin. In Amos 8:4-5 he also recognized that such abridgement of the Sabbath compromised the rights of workers and disenfranchised them as they had. been in Egypt.

\footnotetext{
${ }^{28}$ Ellen G. White, Prophets and Kings (Mountain View, CA: Pacific Press, 1917), 330.

${ }^{29}$ Hasel and Murdoch, "The Sabbath in the Prophetic and Historical Literature," 45.
} 
Hosea used the imagery of "a wayward wife [Israel] and a hurting husband [God]"30 and all of Israel's celebration, including "her Sabbaths" (Hosea 2:11), God terminated. In like manner, Isaiah proclaims God's disgust with Judah's “iniquity and solemn assembly" (Isaiah 1:13) which encompassed their meaningless Sabbaths that had become unbearable to Him.

But positive references to Sabbath observances in Isaiah are also found in chapters 56,58 , and 66 . Verses $2-7$ of chapter 56 offered manifold blessings to everyone who kept the Sabbath, including Gentiles and castrated men. And although God was displeased with the type of fasts that were being practiced, He indicated the key elements of true Sabbathkeeping that flows from genuine fasting in verses 13-14 of chapter 58 . Then in the 66th and final chapter of the book, verses 22-23 revealed God's plan for Sabbath observance in "the new heavens and the new earth... [when] all flesh shall come to worship before me, declares the LORD."

Evidence from late seventh and sixth century references

Jeremiah connects his message on keeping the Sabbath holy to the Sabbath command given by God to their forefathers in Jeremiah 17:22. And in Lamentations 2:6 he makes a post-destruction comment on the results of Israel's unfaithfulness such that "the LORD has made Zion forget festival and Sabbath."

Ezekiel speaks emphatically on the subject of Sabbath observance in six chapters.

${ }^{30}$ Jon L. Dybdahl, "A Wayward Wife and a Hurting Husband," in Hosea-Micah: A Call to Radical Reform, The Abundant Life Bible Amplifier, gen. ed. George R. Knight (Boise, ID: Pacific Press, 1996), 36. 
The sins of Jerusalem's residents, including that of desecrating the Sabbath and shutting their eyes to the keeping of Sabbaths, are recounted in chapter 22, verses 8-26.

In chapter 23 Ezekiel uses allegorical language to describe the infidelity of Samaria and Jerusalem in graphic detail. One of the ways in which both committed adultery was the desecration of the Sabbath (v. 38).

The priests are reminded to keep God's Sabbaths holy in verse 24 of chapter 44. And specifications for the contributions of the entire nation for the regular sacrifices of the temple are addressed in chapter 45 . These donations were to be made to the prince of Israel who would use them for Sabbath offerings according to verses13-17. And much of chapter 46 is concerned with regulations involving the worship by the prince and the people. $^{31}$

But it is the twentieth chapter of Ezekiel that evidences the intimate nature of Sabbath observance. Like a wedding band, Sabbathkeeping is referred to as a sign between God and His people in verses 12 and 20. In verse 12 the sign is intended to remind the Israelites that it is the LORD that made them holy. Verse 20 accentuates that the LORD is a personal God-“your God."

Evidence from fifth century references

Nehemiah 9:13-14 records a prayer of confession which includes an acknowledgement of the Sabbath as holy. Then in the following chapter, the Israelites "join with their brothers, their nobles, and enter into a curse and an oath to walk in God's

\footnotetext{
${ }^{31}$ Robert K. Mclver, "The Services of the New Temple," in Ezekiel: Through Crisis to Victory, The Abundant Life Bible Amplifier, gen. ed. George R. Knight (Boise, ID: Pacific Press, 1997), 230.
} 
Law that was given by Moses the servant of God, and to observe and do all the commandments of the LORD our Lord and his rules and his statutes" (10:29).

Having had the Book of the Law read in their hearing, the Israelites proceed to specify particular binding agreements and promised in verse 31 not to purchase grain or merchandise from neighboring peoples on the Sabbath and in verse 33 to make provisions for Sabbath offerings.

Verses 14-30 of the last chapter in this book comprise a final prayer in which Nehemiah recounts many of his reforms. To prevent buying and selling on the Sabbath in Jerusalem, he ordered the doors to be shut during the Sabbath hours, stationed men at the gates to guard them against merchants who camped outside beside the wall overnight and issued a stern warning to merchants as well.

\section{Evidence of Sabbath Observance from the Psalms and Wisdom Literature}

Acknowledging that "few references/allusions to the Sabbath appear in the OT Psalms and Wisdom Literature, ${ }^{32}$ Richard M. Davidson, J. N. Andrews Professor of Old Testament Interpretation of the Seventh-day Adventist Theological Seminary at Andrews University, argues convincingly that they "make a significant contribution to the overall theology of Sabbath in Scripture." 33

Beginning with Psalm 92, that includes the superscription: “A psalm. A song. For the Sabbath," Davidson illuminates the sabbatic literary features, the sabbatic chiastic structure along with sabbatic themes, motifs, and theological context in this psalm that

\footnotetext{
${ }^{32}$ Richard M. Davidson, "The Sabbath in the Old Testament Psalms and Wisdom Literature," 1. ${ }^{33}$ Ibid.
} 
are consistent with other portions of the Old Testament. He notes, "The numerous patterns of sevens running structurally and terminologically throughout the psalm seem to link literary form and features of the psalm to a septiniary motif, and these patterns are so striking that the superscription is seen to accurately reflect the canonical sabbatical character of the poem." 34

Turning to figure 1, the sabbatic chiastic structure of the psalm, Davidson explains and illustrates this device using the analogy of "a mountain-climbing structure. $" 35$

Just as in climbing a mountain one encounters specific types of plants and animals living together in a certain order in what scientists call ecological zones, and then upon descending the other side of the mountain, the zones appear in reverse order; so in a literary chiasm we find a reverse parallelism: the first item parallels what comes last; the second item parallels what appears next to last, the third parallels the third from the last, etc. Also, just as when climbing a mountain, the climax of the experience is the view from the top of the mountain, so in biblical chiasms the central and most important point usually appears at the center, or midpoint, of the literary work. ${ }^{36}$

Regarding the chiastic structure of the psalm, Davidson further asserts that the "terminological and thematic parallels between the matching parts of the 6 outer sections, coupled with the thematic/structural parallels between the opening, concluding and central sections, suggest a septenary, chiastic macro-structure to the entire psalm.",37

\footnotetext{
${ }^{34}$ Davidson, "The Sabbath," 6.

${ }^{35}$ Davidson, A Love Song for the Sabbath, 12-13.

${ }^{36}$ Ibid., 12.

${ }^{37}$ Ibid., 13.
} 


\section{EXALTATION}

(God's Character)

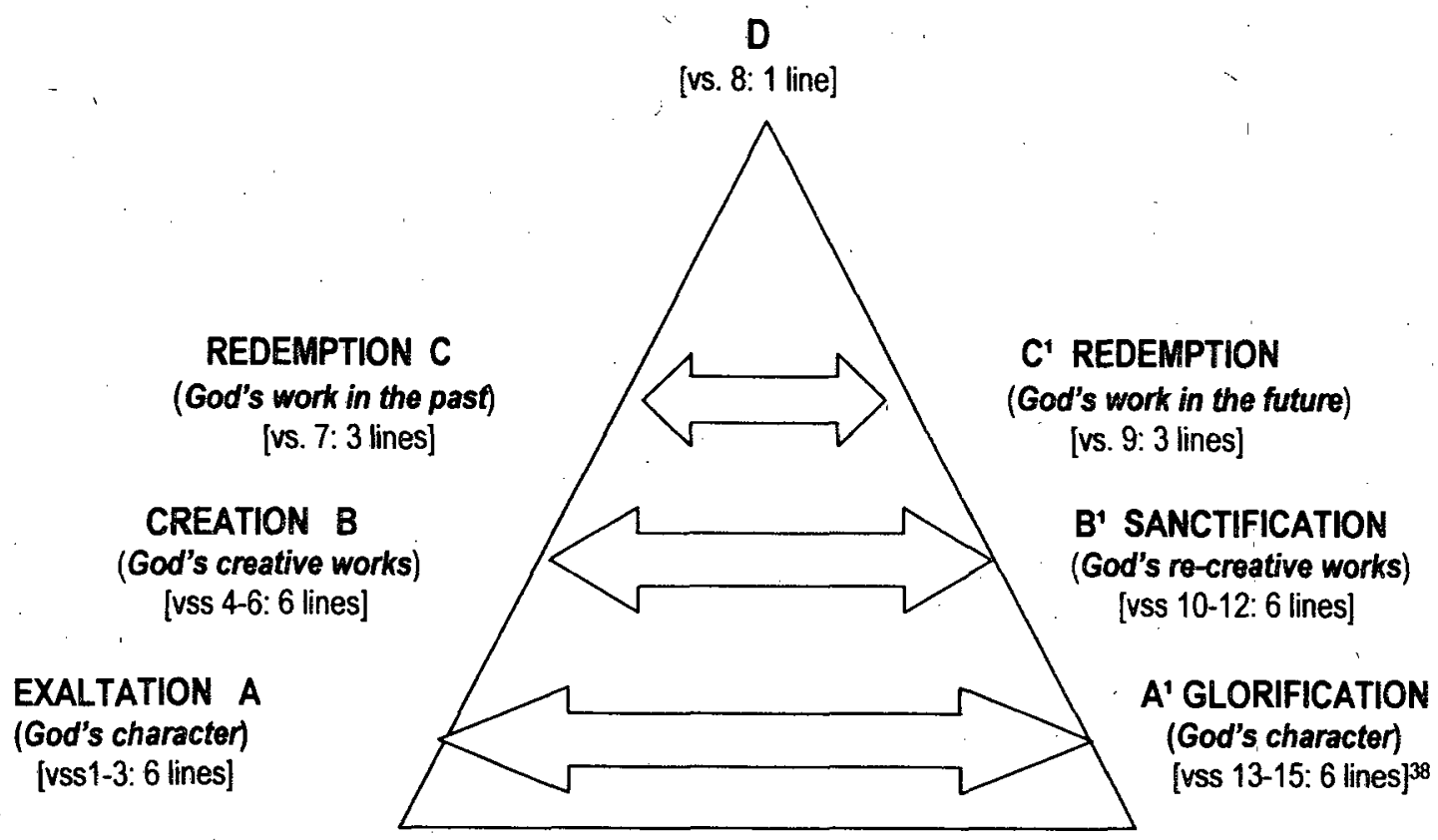

Figure 1. The sabbatic chiastic structure of the psalm.

In his critique of the sabbatic themes embedded in the psalm, Davidson argues that it was "canonically envisioned as the Psalm for the Sabbath par excellence, encompassing the cultic worship mode, prevailing mood, primary motivations, and essential theological meaning of the biblical Sabbath of Israel."39

Having set a tone of joyous exultation, the first stanza of Psalm 92 is unpacked in the succeeding ones as the motivation for jubilation is identified in the acknowledgement of God as Creator of humankind and the Sabbath; the Redeemer or Deliverer, past and future; the Provider of "ongoing covenant blessings,"

\footnotetext{
${ }^{38}$ Davidson, "The Sabbath," 6.

${ }^{39}$ Ibid., 10.

${ }^{40}$ Ibid., 17.
} 
and the Eschaton, such that the entire psalm accomplishes the goal of revealing God's character.

Turning to less explicit indicators of sabbatic content in the Old Testament Psalms, Davidson concurs with the research of Seventh-day Adventist theologians Jacques Doukhan and William Shea regarding possible allusions to Sabbath in Psalm 104 and concludes that sufficient evidence exists.

Significant insights into Sabbath theology emerge from Psalm 104:31-35, including themes of God's glorification and rejoicing in His created works, the presence of God (theophany) leading to both reverential awe and joyous intimacy between the Creator and His creation, exuberant singing and praise in worship of God, silent meditation on the Lord and the eschatological end of the wicket who refuse to give God praise. ${ }^{41}$

The book of Job seems to imply God's ultimate intentions for the Sabbath from both the divine and human perspectives. First God identifies Himself as the sole Creator of all that is when He recounts in detail the scope of His handiwork (38:4-41:34). Then Job acknowledges a more personal connection to and dependence on God when he differentiates between having heard of God in the past (second-hand experience) and finally seeing God (first-hand experience) for himself (42:5).

Finally, Davidson compares the language of Proverbs 8:30-31 and that of Psalm 104:31 and 24 with the wording of Genesis $2: 3$ to suggest an allusion to the Sabbath also.

As Samuele Bacchiocchi reveals in his landmark work Divine Rest for Human Restlessness, the preponderance of evidence is that throughout the Old Testament God continually refers to the seventh-day Sabbath as a reminder of His creative power in relation to human creatureliness; as a sign of His fidelity to His people in perpetuity; as a

\footnotetext{
${ }^{41}$ Davidson, "The Sabbath," 27.
} 
remembrance of liberation from bondage; as a sign to remind His people that He is the One Who set them apart as dedicated to Himself; and as a sign of belonging.

\section{New Testament Evidence of Sabbath Observance}

The New Testament presents the Creator and Lord of the Sabbath as the model and paradigm for understanding the correct theology of Sabbath and Sábbath observance. Further it recounts the Sabbathkeeping practices of his disciples/apostles in imitating that which they had observed in their Master. From Matthew to Revelation the evidence of seventh-day Sabbath observance is consistent.

\section{Evidence of Sabbath Observance from the Gospels}

Kenneth Strand introduces the evidence of the Gospels by highlighting three important matters with references to the Sabbath. First, regarding the charges of Sabbathbreaking that were leveled against Jesus, he identified what was really being challenged. Second, he enunciates the basic principle that was central to what Jesus said about and did on the Sabbath. And last, he exposes the attitude and purpose of Jesus in relationship to the law and particularly to the Sabbath. ${ }^{42}$

Evidence of Sabbath observance in non-controversial settings

Mark and Luke both record instances of Jesus worshiping in synagogues on the Sabbath without incident, even when he was teaching (Mark 1:21; 6:2; Luke 4:16, 31; and 13:10). Luke even goes so far as to identify this practice as his custom (Luke 4:16).

\footnotetext{
${ }^{42}$ Kenneth A. Strand, The Sabbath in Scripture and History (Hagerstown, MD: Review and Herald, 1982), 502.
} 
The Synoptics also describe healings on the Sabbath early in the ministry of Jesus that did not arouse the ire of the religious hierarchy. Mark and Luke both provide the story of Jesus healing a demon-possessed man who interrupted synagogue services in Capernaum on the Sabbath without inciting a showdown with the religious leadership (Mark 1:21-28; Luke 4:31-37). And all three gospel writers indicate the Jesus healed Peter's mother-in-law later the same Sabbath with no outcry from his enemies (Matt 8:14-15; Mark 1:29-31; Luke 4:38-39).

When Jesus sat with His disciples to answer their questions concerning the destruction of Jerusalem and the end of the age, he made what some have regarded as a rather cryptic statement recorded in Matthew 24:20: "Pray that your flight may not be in winter or on a Sabbath." The inconveniences of travel during inclement times are easily understood but why Jesus included Sabbath travel in this context requires more consideration. Specht offers that "the prohibition regarding traveling no more than a 'Sabbath-day's journey' was a post-Exilic Rabbinic regulation. Inasmuch as Jesus ignored other such man-made rules of Sabbathkeeping, it is doubtful that He would have endorsed this one. ${ }^{43} \mathrm{He}$ adds, "The fear, bustle, and confusion that a hasty flight on Sabbath would bring were not in harmony with the worship, peace, and joy that should characterize the sacred day of rest. Hence, Jesus' followers were urged to pray that the flight would be on a different day of the week. $\$ 44$

Of special significance is the testimony of Sabbathkeeping in the Passion

\footnotetext{
${ }^{43}$ Specht, Walter F. "The Sabbath in the New Testament," in The Sabbath in Scripture and History, ed. Kenneth A. Strand (Washington, DC: Review and Herald, 1982), 103.

${ }^{44}$ Ibid.
} 
narratives. Mark notes that it was "Preparation Day" when "Joseph bought a linen shroud, and taking him down, wrapped him in the linen shroud and laid him in a tomb that had been cut out of the rock" $(15: 46)$ and that "when the Sabbath was past, Mary Magdalene, and Mary the mother of James and Salome bought spices so that they might go to anoint him" (16:1). Luke adds a bit more detail and documents that "it was the day of Preparation, and the Sabbath was beginning" (23:54) when Joseph "took it [Jesus' body] down, wrapped it in linen shroud and laid him in a tomb cut in stone, where no one had ever yet been laid" (23:53). He continues and chronicles that "the women who had come with him from Galilee followed and saw the tomb and how his body was laid. Then they returned and prepared spices and ointments. On the Sabbath they rested according to the commandment" (23:55-56). Regarding the death of Jesus, John registers the fact that "since it was the day of Preparation, and so that the bodies would not remain on the cross on the Sabbath (for that Sabbath was a high day)" (19:31), perhaps because of the concurrent Passover celebration, "and since the tomb was nearby, they laid Jesus there" (19:42).

Then all four of the gospels affirm that the resurrection of Jesus did not occur until the first day of the week (Matt 28:1-7; Mark 1:9; Luke 24:1-8; John 20:1-2). Clearly the Gospel accounts of this pivotal weekend emphasize that not only did Jesus rest on that Sabbath in the tomb, but the dedicated female disciples did as well.

Evidence of Sabbath observance in incidents involving controversy

The one "Sabbath conflict" that did not involve healing, and the first mentioned in all of the Synoptics, describes the disciples of Jesus plucking (reaping) and rubbing 
together (threshing) wheat heads on the Sabbath as they walked through some grain fields. The disciples were hungry and Jesus was held responsible for the unlawful actions of His disciples by the Pharisees (Matt 12:1-2). Not only does Jesus regard His disciples as innocent of wrongdoing, referring to the example of David feeding his hungry companions the bread exclusively designated for the priests and how those same priests desecrate the Sabbath but are without guilt (Matt 12:3-5; Mark 2:23-25; Luke 6:3-4), but He takes this occasion to assert "Christ's sovereignty over the Sabbath"45 (Matt 12:8; Mark 2:28; Luke 6:5) and the purpose of the Sabbath as a blessing to those He had created in His image and in His likeness (Gen 1:26).

Skip MacCarty comments on this dispute in his essay on "The Seventh-day Sabbath" in the 2011 publication, Perspectives on the Sabbath.

His critics accused them [Jesus' disciples] of breaking the Sabbath. When they attacked Jesus with their "you aren't keeping the Sabbath right" accusations based on their manmade regulations, they were accusing the architect and engineer of creation week (John 1:1-3), the one who had Himself blessed the seventh day and made it holy.... He defended His disciples who had broken a Sabbath regulation established by the Pharisees but not by Scripture. He used the occasion to reiterate what had been true from the beginning: "The Sabbath was made for man, not man for the Sabbath" (Mark 2:27). Their multitudinous minute restrictions had reversed the formula. He then announced that He was "Lord even of the Sabbath" (Mark 2:28), its very Creator, and thus its rightful Interpreter. ${ }^{46}$

Each of the gospel writers records at least once incident of Jesus restoring physical health on the Sabbath that led to controversy. All of the Synoptics attest that a man with a withered hand was healed by Jesus in a synagogue on the Sabbath in the presence of Pharisees and teachers of the law who "watched him, to see whether he

\footnotetext{
${ }^{45}$ Specht, "The Sabbath in the New Testament," 96.

${ }^{46}$ MacCarty, "The Seventh-day Sabbath," 20-21.
} 
would heal on the Sabbath, so that they might find a reason to accuse him" (Matt 12:10; Mark 3:2; Luke 6:7), and baited Him with the question "Is it lawful to heal on the Sabbath?" (Matt 12:10).

In Mark's account Jesus, who "knew their thoughts" (Luke 6:8), takes the initiative and asks his would-be accusers, "Is it lawful on the Sabbath to do good or to do harm, to save life or to destroy it?" (Luke 6:9). Specht declares that "they could not, of course, say that it was lawful to do harm, and they would not say it was lawful to do good. Hence they remained silent." ${ }^{, 47}$

Matthew further reveals the hypocrisy of these spiritual leaders by sharing how Jesus pointed to the greater measure of compassion they had for animals in harm's way on the Sabbath as compared to the value they placed on a fellow human being. And their response to the restoration of wholeness to the man's hand was neither lawful nor spiritual (Matt 12:14; Mark 3:6; Luke 6:11). "Thus while they were unwilling to see a man with a deformed hand restored on the Sabbath, they felt no compunctions about plotting the death of the one they hated"48 on the Sabbath.

Luke relates two other occurrences of miraculous healing on the Sabbath that caused Jesus on both occasions to expose the deceitfulness and pretenses of the religious leaders in their supposed higher regard for animals than for people. On a Sabbath when Jesus was teaching in the synagogue, He healed a woman who had been crippled for eighteen years to the chagrin of the synagogue ruler (13:10-17) and at the home of a

\footnotetext{
${ }^{47}$ Specht, "The Sabbath in the New Testament," 98.

${ }^{48}$ Ibid.
} 
prominent Pharisee, where he was being carefully watched, Jesus healed a man suffering from dropsy on the Sabbath (14:1-6).

The Gospel of John also narrates two stories of healings on the Sabbath. Both accounts involve pools of water as well as two encounters between the Healer and the healed. The first is the report of a man who had been an invalid for thirty-eight years and who had staked his future on being the first to get into the Pool of Bethesda when the water was stirred (5:7). Initially, it is the happy pedestrian who is accused of breaking the Sabbath because he was carrying the last vestiges of his infirmity (5:10). Later Jesus finds him at the temple, no doubt praising God for not only his healing but for being able to participate in corporate worship after such a long absence. Here the man becomes acquainted with Jesus and subsequently shares with the Jews that it was He who had made him well (5:15). This provided them with cause for persecuting Jesus whose response infuriated them to the extent that they "tried all the harder to kill him". (5:18) as He identifies Himself with God who "is always at his work to this very day" (5:17).

"God was constantly active in sustaining the universe and also in the work of redemption of human beings. Jesus claimed simply, but forcefully, that He was participating in this ongoing divine redemptive activity, an activity fully compatible with the intent of Sabbath., ${ }^{49}$

The second is the recording of a man, blind from birth, who, after Jesus put mud cakes on his eyes, was told to "wash in the Pool of Siloam" (John 9:7). Once again, Jesus has left the scene of the healing and the newly-sighted man has no idea who or where Jesus is when interrogated (vv. 8-12). He is then brought to the Pharisees where his

\footnotetext{
${ }^{49}$ Strand, "The Sabbath," 504.
} 
inquisitors are unwilling to accept his testimony so they question his parents before calling him back for a second round of probing (vv. 13-29) and finally throw him out when his logical responses prove to be sources of embarrassment at having been exposed (vv. 30-34). When Jesus heard that he had been thrown out [of the synagogue, presumably - the damning consequence feared by his parents (v. 22)], He found the man (v. 35), offered him eternal life (9:35/3:16-18) and received his worship (9:38). "These miracles were thus a proclamation of Jesus' divinity and Messiahship." ${ }^{\text {50 }}$

\section{Evidence of Sabbath Observance from Acts of the Apostles}

The prominence of the word "Sabbath" in the book of Acts is significant to the extent that of the nine occurrences in the King James Version, eight are associated with worship on the seventh day of the week after the resurrection of Jesus. The one other reference to the Sabbath depicts the disciples, after the ascension of Jesus, as they return 'to Jerusalem from the hill called the Mount of Olives, a Sabbath day's walk from the city (Acts 1:12)."

With the exception of a brief, even parenthetical, reference at the close of the speech made by James at the conclusion of the Jerusalem Conference that determined the expectations and requirements of Gentile Christians (Acts 15:21), the remaining Sabbath notations are always in the context of Paul's preaching, teaching and worship in Pisidian Antioch (Acts 13:13-52); Philippi (Acts 16:11-15); Thessalonica (Acts 17:1-9); and Corinth (Acts 18:1-4). Regarding the Jerusalem Conference, Specht notes the following:

It is significant that the matter of Sabbathkeeping is not mentioned as an issue at this conference. Had there been a movement on foot to do away with the Sabbath or to

\footnotetext{
${ }^{50}$ Strand, "The Sabbath," 504.
} 
change the day of worship to Sunday, there would no doubt have been considerable debate and bitter contention on the part of the large number of Jewish Christians who were " 'zealous for the law"' (chap. 21:20). Gentiles were not admonished to respect the scruples of their Jewish brethren with reference to the Sabbath. The silence of the conference on this subject eloquently testifies to the continual observance of the Sabbath by both Jewish and Gentile Christians. ${ }^{51}$

What is equally telling is that nowhere in the book of Acts is there a record of the apostles observing any other day of the week for worship.

\section{Evidence of Sabbath Observance from the Epistles}

Roy Gane situates the reference to sabbaton in Colossians 2:16 in the context of the larger controversy plaguing the church in that locale. It reads, "Therefore, do not let anyone judge you by what you eat or drink, or with regard to a religious festival, a New Moon celebration or a Sabbath day."

The words for "eating" and "drinking" are simply preceded by the Greek preposition $e n$, literally "in": "So let no one judge you in (en) eating or in (en) drinking. ... The rest of the verse, however, literally reads: “. . . on in (en) part of (merei) a festival or new moon on Sabbath." 'The preposition en here is used distributively, as if it preceded all three terms for time, so this does not signal a difference. If only en appeared here, a Christian should not permit anyone to judge him/her "in," i.e., in regard to, five things: eating, drinking, festival, new moon, or Sabbath. However, the addition of the noun meros (here in the dative form merei) before "a festival or new moon or Sabbath" indicates that non-allowance of judging is not simply in regard to these sacred times, but in regard to the shadowy aspects of them. In the context of Colossians 2:16, "new moons" and "Sabbaths" refer to ritual activity performed on these days rather than to the days themselves. ${ }^{52}$

At issue in this difficult passage is the problem that in spite of Christ's victory and removal of condemnation against sinners through the cross (cf. vv. 13-15), some early Christians were mistakenly prone to judge/despise others (cf. Rom 14:3) for not

\footnotetext{
${ }^{51}$ Specht, "The Sabbath in the New Testament," 111.

${ }^{52}$ Ibid., 21.
} 
engaging in ascetic practices, which involved matters of diet and observance of holy times, in accordance with their philosophy. ${ }^{53}$

Gane explains his interpretation of sabbaton in Colossians 2:16 as including the seventh day Sabbath but does not ascribe to the interpretation that limits the word to meaning ceremonial sabbaths.

Kenneth Strand very helpfully points out that the context of the Sabbath reference in Colossians 2:16, as well as that of festivals and new moons, is ceremonies, "not with days per se.... In short, Colossians is here dealing with a ceremonialism that had lost sight of Christ, who is the very substance to which the OT ceremonies pointed.".54

In the letter to the Hebrews the word "rest" figures prominently in the third and fourth chapters. Some form of the Greek word katapausis appears eleven times in these two chapters and it conveys the concept of "cessation from labor or other activity, together with the state of inactivity that follows cessation.... In each instance katapausis is definite, specifying a particular rest, God's rest." ${ }^{55}$

A second word for "rest," sabbatismos is located in Hebrews 4:10. This term came to mean "a Sabbathkeeping," from the verb sabbatizo, 'to rest', 'to cease', 'to keep Sabbath. ${ }^{\prime 56}$ Strand suggests that "in view of the 'rest' concept within the entire pericope, those who interpret the statement about 'sabbath rest' in a metaphorical sense

${ }^{53}$ Roy Gane, "The Role of God's Moral Law, Including Sabbath in the "New Covenant"' (Silver Spring, MD: Biblical Research Institute, 2003), 15.

${ }^{54}$ Strand, "The Sabbath," 506.

55"Interpretation of Hebrews," SDA Bible Commentary, ed. F. D. Nichol (Washington, DC: Review and Herald, 1980), 7:413.

${ }^{56}$ Ibid., 7:22. 
appear to be doing the best justice to what is intended." ${ }^{, 57}$ As well the contributors to the Seventh-day Adventist Bible Commentary conclude that "to declare that what remains for the 'people of God' is the weekly Sabbath is to declare that what Joshua failed to lead Israel into was the weekly Sabbath." ${ }^{\text {58 }}$ Assuming that the author of Hebrews was addressing a Jewish audience, the commentators continue:

There would have been no point in so labored an effort to persuade the Jews to do what they were already doing-observing the seventh-day Sabbath. Furthermore, in apostolic times the seventh-day Sabbath was observed by all Christians, Jew and Gentile alike, and any argument to prove the validity of the Sabbath in those early Christian times would have been pointless. ${ }^{59}$

But Erhard H. Gallos argues for a very different conclusion and he constructs the basis for his determination by first exegeting the context for/of the epistle, contending that the letter was addressed "to a community of Christians who obviously underwent a three-phase development" ${ }^{60}$ and was, at that time, bordering on apostasy. He proposes that the meaning of rest in Hebrews 4 is "a real seventh-day Sabbath observance with the hypothesis in mind that the audience is in danger of abandoning this Sabbath observance." ${ }^{\circ 1}$ Gallos also points to parallel features of the fourth and tenth chapters of Hebrews to make his case, underscoring the significance of the similarities"in "structural

${ }^{57}$ Strand, "The Sabbath," 507.

58،"Interpretation of Hebrews," 7:423.

${ }^{59}$ Ibid.

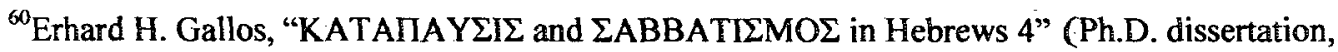
Andrews University, 2011), 294.

${ }^{61}$ lbid., 199. 
features, lexical and semantic cohesion, formal constituents, syntactical elements, and the same genre. ${ }^{, 62}$ He offers,

The exhortation of a Sabbath observance in Heb 4 has been shown to be complementary to the neglecting of the gathering in Heb 10 . Since structurally these two units are related, the proposed thesis that they are also topically related has been valuable. Only by recognizing the structure does continuity in content become evident and explanatory since the theme of "rest" as such does not appear again in the composition. ${ }^{63}$

Three times the recipients of this letter are made to recall the warning of Psalm 95 , "Today, if you hear his voice, do not harden your hearts" $(3: 7 ; 3: 15 ; 4: 7)$ and the first two admonitions include the phrase "as in the rebellion," referring to the disobedience and unbelief of the Israelites in the wilderness that cost most of the adult population to miss the experience of the Promised Land and the rest God offered. Now the pastoral concern of the author urges his audience to be faithful "today," a word pregnant with the critical need for immediate response and repeated five times in this context. Time is of the essence as Gallos demonstrates in his unpacking of Hebrews 4:7.

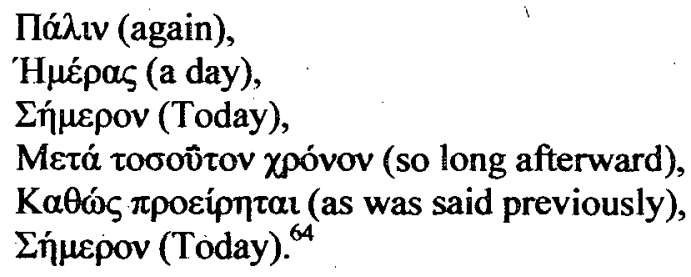

William Johnsson addresses the significance of time noting that with each of the three "today" appeals in Hebrews 3 comes a warning about the danger of hardening the heart. He declares that "the "hardening" process is slow - no one suddenly becomes a

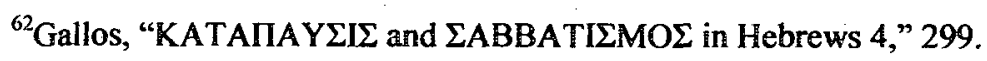

${ }^{63}$ Ibid.

${ }^{64}$ Ibid., 184.
} 
rebel. And it is subtle - sin's deceitfulness masks our eyes to what is happening within us." "W5 "What is 'today'? It is God's eternal now. It is this moment, pregnant with divine warning and grace. It is this moment of opportunity. It is this moment to take stock and see where we are headed and to turn back to God's will for us."

Like Gallos, Johnsson finds a "carelessness in religion, not an open rejection of Christ and His people"67 such that "chapter 3:12-15 with its description of the insidious change of heart expands our understanding of the consequences of ignoring "such a great salvation" in 2:3." 68

Gallos also ties together the cords of creation and rest as he situates his stance on the temporal designation of the rest that remains. He concludes, "I can say that rest in the context is the eternal sabbatical repose, because its predecessor was the Sabbath rest God entered after he finished his works of creation at the end of the first week, not a future rest in the heavenly temple or a metaphysical reality. The time frame mentioned in Heb 3 and 4 seems to place the rest before the parousia rather than afterwards. ${ }^{~} 69$

Additionally, he points to "the intricate chiastic structure (4:3c-4) between the two citations of Ps 95:11/Gen 2:2 and places the key idea of God's creation rest at the very center. $^{, 70}$

${ }^{65}$ William G. Johnsson, Hebrews: Full Assurance for Christians Today, The Abundant Life Bible Amplifier, gen. ed. George R. Knight (Boise, ID: Pacific Press, 1995), 86.

${ }^{60}$ Ibid., 84.

${ }^{67}$ Ibid., 86.

${ }^{68}$ Ibid.

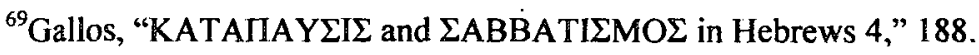

${ }^{70}$ Ibid., 207. 
Ultimately, he claims a progressive transformation in the word used for rest in this passage such that katapausis becomes sabbatismos at the climax of the pastor's appeal for faithfulness. Having made his case, the author ends this portion of his pastoral letter with three exhortations: "Let us therefore strive to enter that rest" (4:11); "Let us hold fast our confession" (4:14); and "Let us then with confidence draw near to the throne of grace" (4:15).

Gallos and Johnsson make a convincing argument for their conclusions that there is continuity in the Sabbath rest which remains for God's people with which I concur. Samuele Bacchiocchi agrees.

The verb "remains— $\alpha \pi 0 \lambda \varepsilon u \pi \varepsilon \tau \alpha u$ " literally means "has been left behind." Literally translated, verse 9 reads: "So then a Sabbath-keeping has been left behind for the people of God. The permanence of the Sabbath is also implied in the exhortation to "strive to enter that rest" (Hebrews 4:11). The fact that one must make efforts "to enter that rest" implies that the "rest" experience of the Sabbath also has a future realization and, consequently, cannot have terminated with the coming of Christ. ${ }^{71}$

Further evidence for Sabbath observance is supplied in the book of Revelation as John, the beloved friend of Jesus, writes that he was "in the Spirit on the Lord's Day" (Revelation 1:9). Joseph A. Pipa, president and professor of historical and systematic theology at Greenville Presbyterian Theological Seminary, asserts that

The church has always recognized that the change of the day was first initiated by the resurrection appearances of Christ on the first day of the week when all of the New Testament's recorded appearances took place... The Lord's Supper is not an ordinary meal but a meal that belongs exclusively to the Lord and was appointed to celebrate His redeeming work and to communicate grace to His people. In like manner, the first day of the week is called the Lord's Day because it is a day that belongs peculiarly to the Lord and was appointed to commemorate His completed redemption and to communicate grace to His people. ${ }^{72}$

\footnotetext{
${ }^{71}$ Samuele Bacchiocchi, The Sabbath Under Crossfire: A Biblical Analysis of Recent Sabbath/Sunday Developments (Berrien Springs, MI: Biblical Perspectives, 1998), 124.
} 
Contrary to popular consensus however, "the Lord's Day" is clearly and peculiarly the seventh-day Sabbath and not Sunday, the first day of the week, by virtue not only of His being the One Who created, blessed, sanctified, and rest on it (Genesis 2:2-3), but in Mark 2:28 He declared His sovereignty over it as "Lord even of the Sabbath." Jon Paulien, Dean of the School of Religion at Loma Linda University, declares that "the issue in the final crisis of earth's history is clearly worship.,"73 Referring to Revelation 14:7, he makes the following critical observation:

The interesting thing is that the language of this central affirmation is based on the fourth commandment expressions in Exodus 20:11. There it states, "In six days the Lord made the heavens and the earth, the sea, and all that is in them..." This language is reflected in Revelation 14:7: "Worship Him who made the heaven and the earth, the sea and the fountains of water." At the decisive centerpoint of Revelation's description of the final crisis is a direct allusion to Exodus $20{ }^{74}$

\section{Biblical Descriptions and Significance of Sabbath Observance}

Old Testament Descriptions and Significance of Sabbath Observance

Gerhard Hasel maintains that the Old Testament "remains the major source for information on the origin, institution, purpose and meaning of the seventh-day Sabbath." 75 Therefore this section will present the descriptions and significance of Sabbath observance from the Pentateuch, the historical and prophetic books, and from the wisdom literature and the psalms.

\footnotetext{
${ }^{72}$ Joseph A. Pipa, "The Christian Sabbath," in Perspectives on the Sabbath: Four Views, ed. Christopher John Donato (Nashville, TN: B\&H Academic, 2011), 164-165.

${ }^{73}$ Jon Paulien, "Revisiting the Sabbath in the Book of Revelation," in Journal of the Adventist Theological Society, 9, nos. 1-2 (1998): 182.

${ }^{74}$ Ibid, 183.

${ }^{75}$ Bacchiocchi, The Sabbath Under Crossfire, 124.
} 


\section{Descriptions and Significance of Sabbath Observance from the Pentateuch}

Richard Davidson's chapter in the Festschrift honoring Jon Dybdahl identifies seven dimensions of rest found in the Torah. Beginning with the proclamation that "Sabbath is a verb," "76 Davidson then proceeds to identify "the seven different Hebrew verbs to describe the experience of Sabbath. These verbs encapsulate seven dimensions of joyous Sabbath rest: physical, mental, emotional, creative, spiritual, blessed and holy." 77

Physical (work-free) rest is the first of the Sabbath rest dimensions addressed in this chapter as the verb shabat is introduced in Genesis 2:2 to indicate that God ceased "from all His work which He had done." The second dimension of Sabbath rest is mental (intellectual) rest which the verb nuach announces in Exodus 20:11. Unlike shabat this verb indicates that "that divine will is not only that humans experience tranquil repose on the Sabbath, but also the animals." 78

Exodus 31:17 utilizes the Hebrew verb naphash which refers to the third Sabbath rest dimension of emotional (restorative) rest. The text refers to God as resting and being refreshed on the seventh day and Davidson is correct in asserting that "on the Sabbath God invites us to recharge our emotional battery, to refresh and restore our soul. .79

The fourth Sabbath rest dimension of creative (celebrative, social) rest is

${ }^{76}$ Richard M. Davidson, "Sabbath, Spirituality, and Mission: Torah's Seven Dimensions of Sabbath Rest" in Encountering God in Life and Mission, ed. Rudi Maier (Berrien Springs, MI: Department of World Mission, 2010), 3.

$$
\begin{aligned}
& { }^{77} \text { Ibid. } \\
& { }^{78} \text { Ibid., } 6 . \\
& { }^{79} \text { Ibid., } 7
\end{aligned}
$$


addressed in the verb 'asah which is found in Exodus 31:6 where the Israelites are admonished to observe or "'make' the Sabbath, as God made the heavens and the earth, with all the creativity and energy and joy that God displayed in His creative process. Davidson goes to great lengths to describe the degree to which the Sabbath should incorporate special sabbath celebrations including welcoming the Sabbath with the exquisite delight indicated by the Hebrew noun 'oneg which is only used in the Old Testament to describe the Sabbath and royalty. He argues for engaging in acts of humanitarian service on the Sabbath including humane service to animals such as those found in shelters.

Genesis 2:2 also provides the context for the fifth dimension of Sabbath rest as the verb kalah declares that God finished the work that He had done. Davidson declares this to be the spiritual (gospel) rest and provides a critical insight into the beauty of this facet. "God rested by ceasing from his works on the Sabbath, and He invited Adam and Eve to rest on that first Sabbath. From what were Adam and Eve resting? From their own works? No, they had been created only a few hours before. They were resting in God's finished work! Thus even before sin, we may infer the profound principles of righteousness by faith. ${ }^{81}$

He points to this facet as not only having the great benefits of peace and assurance for/to Sabbathkeepers, but that it proves to be "a winning witness to the power of Gospel and the truthfulness of the Sabbath to those who behold our 'rest in grace' symbolized by Sabbath rest." ${ }^{92}$

\footnotetext{
${ }^{80}$ Davidson, "Sabbath, Spirituality, and Mission," 10.

${ }^{81}$ Ibid., 13.

${ }^{82}$ Ibid., 14.
} 
The sixth aspect of Sabbath rest in found in Genesis 2:3 where God blessed brk the seventh day. Davidson rightfully concludes that as the Sabbath is filled with power by virtue of being blessed, "we are empowered as we enter into His rest on that Sabbath. And that sabbatic empowerment spills out into all the other days of the week. ${ }^{, 83} \mathrm{He}$ also points to the images of empowerment found in Psalm 92, the Psalm for the Sabbath.

Holy (intimate) rest is the final dimension of Sabbath rest and again Genesis 2:3 provides the context in which God sanctified or made holy the Sabbath. The verb here is qadash and Davidson declares that God makes something holy by His presence and then echoes Heschel in making the case that "the gift of Sabbath rest is not just the gift of the day, but the gift of a Person, filling the day with His loving presence!"84 Contextualizing Exodus 31:13, Davidson states that "in fellowship with God on His only day, we ourselves are made holy as well!"85 He then concludes by inviting "God's people in these last days to experientially receive and treasure this divine gift of Sabbath rest and share it enthusiastically and unabashedly with a restless, dark, and dying world. ${ }^{86}$

Although Leviticus 23:3 identifies the Sabbath as a "holy convocation," thereby calling God's people to assemble together for spiritual development, it offers and provides so much more beyond the benefits of the worship experience for the worshippers. I agree with Davidson that "the multi-faceted experience of Sabbath rest

\footnotetext{
${ }^{83}$ Davidson, "Sabbath, Spirituality, and Mission," 15.

${ }^{84}$ Ibid., 16.

${ }^{85}$ Ibid.

${ }^{86}$ Ibid., 18.
} 
may be regarded as the crown jewel of both biblical spirituality and mission." ${ }^{87}$

It is high time that the Sabbath becomes a powerful vehicle in our mission as a church, not merely as part of evangelistic campaigns showing that the Bible Sabbath is Saturday and not Sunday, but in practical demonstration that the Sabbath day overflows with potent spirituality in the lives of Seventh-day Adventists, with the result that those who encounter such Sabbath-keepers will long to experience this joyous Sabbath rest in their own lives. ${ }^{88}$

\section{Descriptions and Significance of Sabbathkeeping from the Historical and Prophetic Books}

Eleventh and tenth century descriptions of Sabbath observance

In accordance with the mandate of Leviticus 24:8, 1 Chronicles 9:32 records that the showbread was replaced on the golden table every Sabbath by some of the Kohathite brothers. First Chronicles 23:30-31 describes the Levites as being required to stand to thank and praise the LORD whenever burnt offerings were presented to Him on Sabbaths and at New Moon festivals and at appointed feasts. And "Solomon offered up burnt offerings to the LORD on the altar of the LORD that he had built before the vestibule, as the duty of each day required, offering according to the commandment of Moses for the Sabbaths, the new moons, and the three annual feasts - the Feast of Unleavened Bread, the Feast of Weeks, and the Feast of Booths." (2 Chronicles 8:12-13).

Ninth century descriptions of Sabbath observance

The question asked by the Shunamite woman's husband in 2 Kings 4: 23 about

\footnotetext{
${ }^{87}$ Davidson, "Sabbath, Spirituality, and Mission," 3.

${ }^{88}$ Ibid., 4.
} 
her plans to travel so that she could "quickly go to the man of God and come back again" indicates that travel on the Sabbath for such a purpose was not prohibited or considered to be in violation of Sabbathkeeping principles or practices.

A coup orchestrated by the priest Jehoiada that resulted in the dethroning of Athaliah and the crowning of Joash at the changing of the guard on the Sabbath is narrated in both 2 Kings 11:4-20 and 2 Chronicles 23:1-11. Although the priest insisted that Athaliah "not be put to death in the house of the LORD" (2 Kgs 11:15), they laid hands on her, and she went through the horses' entrance to the king's house, and there she was put to death" (v. 16). Then after the priest made a covenant between the LORD, the king and the people, the priest of Baal was also killed as the people tore down the temple of Baal along with its altars and idols. Clearly, this does not reflect God's highest ideal or definition of Sabbath observance although the purging of that which was evil has some apocalyptic overtones.

Eighth century descriptions of Sabbath observance

2nd Chronicles 31:3 indicates that "the contributions of the king [Hezekiah] from his own possessions was for ... the burnt offerings for the Sabbaths, the new moons and appointed feasts as written in the Law of the LORD."

The ire and frustration of the prophet is palpable in Amos 8:4-5 as he rebukes those who exhibit a disdain for the poor and for Sabbath observance by asking, "When will the new moon be over that we may sell grain? And the Sabbath that we may offer wheat for sale?" As such the text reveals that Sabbath observance did not include business transactions. 
Isaiah 56 and 58 are similar in enunciating the LORD's desire for true Sabbath observance to be characterized by choosing what pleases Him (56:4) and refraining from doing as one pleases $(58: 13,14)$. Not desecrating the Sabbath $(56: 6)$ includes choosing one's words well ... calling the Sabbath a delight (58:13); calling the LORD's holy day honorable (58:13); and not speaking idle words (58:13). And the book ends with a view toward Sabbath observance when " "from one Sabbath to another, all flesh will come to worship before me,' declares the LORD (66:23)."

Late seventh and sixth century descriptions of Sabbath observance

Jeremiah 17:21-22, 24 describe Sabbath observance as prohibiting the carrying of loads on the Sabbath or bringing them through the gates of the city. The people were not to bring a load out of their houses and to do no work on the Sabbath.

Although Sabbath observance is not described in the twentieth chapter of Ezekiel, the Sabbath is regarded as a sign between the LORD and His people in verses 12 and 20. Verse 17 of chapter 45 denotes that Sabbath observance includes the prince providing "the burnt offerings, grain offerings and drink offerings at the festivals, the New Moons and the Sabbaths-at all the appointed feasts of the house of Israel." And chapter 46 describes the opening of the gates of the inner court on Sabbath (v. 1); worship in the presence of the LORD at the entrance to that gateway (v. 3); the burnt offering that the prince brings to the LORD (v. 4) as well as his fellowship offerings on the Sabbath (v. 12) as aspects of Sabbath observance. 
Fifth century descriptions

of Sabbath observance

In the days of Nehemiah, the Israelites promised that "if the peoples of the land bring in goods or any grain on the Sabbath day to sell, we will not buy from them on the Sabbath" (10:31). They also "take on ... the obligation to give yearly a third part of a shekel for the service of the house of our God: for the showbread, the regular grain offering, the regular burnt offering, the Sabbaths, the new moons, the appointed feasts, the holy things, and the sin offerings to make atonement for Israel, and for all the work of the house of our God" (10:32-33). By way of addressing the importance of Sabbath observance, Nehemiah takes a stand in chapter 13, verses 15-22 against those who deliberately intend to break the Sabbath by selling on the Sabbath and orders the gates of the city to be closed until the Sabbath was over.

\section{Descriptions and Significance of Sabbathkeeping from the Psalms and Wisdom Literature}

Psalm 92, a song for the Sabbath, describes Sabbath observance in verses 1-3 in terms of praise, making music, and proclaiming God's love and faithfulness.

In light of the creation and implicit Sabbath allusions identified by Davidson previously in Psalm 104, Sabbath observance certainly includes praise (v. 1), singing (v. 33), meditation (v. 34) and rejoicing (v. 34).

The powerful creation references with their Sabbath implications in Job 38-41 strongly intimate that Sabbath observance involves intimate encounter with God (42:5). Proverbs 8:23-32 again repeats the Creation story and concludes with "rejoicing always in his presence" (v. 30), "rejoicing in this whole world" (v. 31), and "delighting in 
mankind" (v. 31) as integral to Sabbath observance.

\section{New Testament Descriptions and Significance} of Sabbath Observance

The example of Jesus, Creator and Lord of the Sabbath, as recorded in the Gospels, continually provides the greatest depiction of Sabbathkeeping and its eternal significance. It was the basis for the worship practices of His disciples-turned apostles in their powerful, life-changing ministries following His ascension as described in Acts and the Epistles.

\section{Descriptions/Significance of Sabbathkeeping from the Gospels in Non-Controversial Settings}

Jesus provides the first descriptions of Sabbath observance in the New Testament with synagogue attendance, preaching and teaching on Sabbath which are recorded as without incident in Mark 1:21; Mark 6:2; Luke 4:16, 31; and Luke 13:10. Further He demonstrates Sabbathkeeping by resting in the tomb (Matt 27:59-28:6; Mark 15:42-16:6; Luke 23:50-24:6) as did the women who attended Him at the tomb (Luke 23:55-24:1). Sabbath observance for Jesus also included healing and the earliest recorded healings on the Sabbath in Mark 1:21-28 (cf. Luke 4:31-37) and Matthew 8:14-15 (cf. Mark 1:29-31 and Luke 4:38-39) took place without challenge.

\section{Descriptions/Significance of Sabbathkeeping from the Gospels involving Controversy}

Providing for the needs of people was an essential aspect of Sabbath observance for Jesus. When His hungry disciples plucked and eat grain while walking through a field on the Sabbath, Jesus defended their actions to the accusing Pharisees with two 
announcements of great consequence regarding the Sabbath. He proclaimed that people were the beneficiaries of the Sabbath and not the other way around and then asserted that $\mathrm{He}$, the Creator of the Sabbath, was also Lord even of the Sabbath (Mark 2:23-28;

Matthew 12:1-8; Luke 6:1-5). In so doing, Jesus redefined Sabbath observance for the ecclesiastical leaders who had burdened it with the multiplicity of their traditions.

Later Sabbath healings by Jesus that invoked the anger of the religious hierarchy because of their distorted interpretations of Sabbath observance are noted in the Gospels as follows: healing of the man with the withered hand (Matt 12:9-13; Mark 3:1-5; Luke 6:6-10); healing of the bent-over woman (Luke 13:10-17); healing of the man with dropsy (Luke 14:1-6); healing of the paralyzed man by the pool of Bethesda (John 5:1-15); and the healing of the blind man (John 9).

It is interesting to note that not all of these healings were of ailments that were chronic or critical. Jesus could have waited until later to heal the acute illnesses/diseases, but He deliberately provoked controversy.

\section{Descriptions/Significance of Sabbath Observance from Acts of the Apostles}

The book of Acts describes many instances of Paul and his companions attending synagogue services as a part of their Sabbath observance. The services included "the reading from the Law and the Prophets" (13:15) as well as preaching as evidenced first by the invitation for them to speak a "word of encouragement for the people" (13:15) when they visited Pisidian Antioch (13:14). Second, preaching.is understood as a part of Sabbath observance and synagogue services when another invitation was extended to Paul and Barnabas "that these things might be told them the next Sabbath" (v. 42) as they 
were leaving the synagogue. As a result, on "the next Sabbath almost the whole city gathered to hear the word of the Lord" (v. 44).

The sixteenth chapter of Acts relates the Sabbath in Philippi when Paul, Silas, and Timothy went outside the city to the river expecting to find a place of prayer and found women to whom Paul preached (Acts 13:13-15). Later in Thessalonica, "as was his custom" (17:2), Paul went into the synagogue, "and on three Sabbath days he reasoned with them from the Scriptures" (17:2). And "he reasoned in the synagogue every Sabbath, and tried to persuade Jews and Gentiles" (18:4).

\section{Descriptions/Significance of Sabbath Observance from the Epistles}

Strand suggests that Colossians 2:16 "refers to temporal celebrations in which 'food and drink' were present" ${ }^{\prime 89}$ which suggests that descriptions of New Testament Sabbath observance include eating and drinking. And although Gallos argues for faithfulness in seventh-day Sabbath observance with the benefit of the rest of grace for the people of God as the focus and appeal of Hebrews 3 and 4, no further description of Sabbath observance is provided in these chapters.

In summary, the Old and New Testaments are replete with descriptions, many prescriptive and a few proscriptive, of Sabbath observance that all people everywhere at all times would do well to recognize, contextualize and incorporate for their inherent temporal and eternal benefits.

\footnotetext{
${ }^{89}$ Strand, "The Sabbath," 506.
} 


\section{Theological Perspectives on Biblical}

\section{Indicators of the Universal and}

Permanent Applicability of Sabbath

Observance

In this portion of the biblical/theological foundations for this dissertation, the contributions of Seventh-day Adventist theologians renowned for their research on the seventh-day Sabbath will be considered. Each biblical scholar will make his arguments in the manner and order of his choice of the biblical indicators of the universal and permanent applicability of Sabbath observance.

Genesis 2:1-3 provide the initial and primary model, rationale, and context for Sabbath and Sabbath observance as well as the basis for their universal and permanent applicability.

Kenneth Strand notes that Genesis 2:1-3 takes the form of a chiasm or inverted parallel statement:

A. God finished his work (verse 2)

B. And he rested on the seventh day from all his work which he had done (v. 2)

C. So God blessed the seventh day and hallowed it (v. 3)

B'. Because on it God rested from all his work which he had done, (v. 3)

A'. In creation (verse 3 , continued)

This chiasm's two introductory statements (A and B) call attention to God's creative work and to His resting on the seventh day. The same two thoughts are presented at the conclusion of the chiasm, in reverse order ( $\mathrm{B}^{\prime}$ and $\left.\mathrm{A}^{\prime}\right)$. This leaves at the center of the chiasm (C) the reference to God's blessing and hallowing the seventh day. In a chiasm that takes this A-B-C-B'-A' form, the central item normally represents the text's major focus. 90

\footnotetext{
${ }^{90}$ Strand, "The Sabbath," 495.
} 
Shabbat, the Hebrew word translated "Sabbath," literally means "rest" and here, in the beginning, at the end of creation week, God provided the model for the seventhday Sabbath by resting "from all his work that he had done in creation" (Gen 2:3). He also supplied the rationale for Sabbath rest in that "on the seventh day God finished his work that he had done" (Gen 2:2). But should the possibility exist to miss the significance of the thrice-referenced "seventh-day," the text satisfies the potential deficiency and conveys the context for Sabbath observance by stating that God both "blessed the seventh day and made it holy" (Gen 2:3) as He had done on no other day.

Barak, the Hebrew word for "bless," means to speak words invoking divine favor

- and the Seventh-day Adventist Bible Commentary suggests that the blessing God pronounced on the seventh day implied "a day that would bring blessing to His creatures." ${ }^{\text {91 }}$ Further, the text uses the Hebrew word qadash to convey the concept of being made holy or sanctified and again, the Seventh-day Adventist Commentary draws a critical connection between this declaration of holiness and its benefit for the human race. "The Sabbath is holy because God fills it with His presence. Therefore the Sabbath is not just a day; but a Person! In a special way during its hours God gives not only rest and power but, most important, Himself.",92

Christopher Donato in his Introduction to Perspectives on the Sabbath declared that "the Sabbath question cannot be relegated to the shelf, for it serves as a microcosm of much larger questions fundamental to the nature of the worshipping community of

\footnotetext{
91"Interpretation of Genesis," SDA Bible Commentary, ed. F. D. Nichol (Washington, DC: Review and Herald, 1953-57), 1:220-221.

${ }^{92}$ Davidson, A Love Song for the Sabbath, 29.
} 
Christ itself." ${ }^{, 93}$ He continues, "Hermeneutical presuppositions and the covenantal (dis) continuity of.God's redemptive plan, among a great many other elements, are at once exposed when discussing this question. More importantly, as Christians we take seriously God's commands: indeed, if we love Him, we will keep His commands (John $14: 15 ; 1$ John 5:3). ${ }^{94}$

One of four contributors to Perspectives on the Sabbath, Skip MacCarty begins his assertion of the seventh-day Sabbath as a universal and permanent gift by calling attention to the universal application (of the fourth commandment) "to servants, animals, and 'the alien within your gates,' and its universal reference to the Lord who made 'the heavens . . . earth ... sea ... and all that is in them." 95 According to MacCarty, the profound need of humankind after the Fall points to the role, universality, and permanence of the Sabbath. "With humankind now engaged in a spiritual life-and-death warfare against a powerful foe, the rest that God offered on the day that He had blessed and made holy at creation became vital to His redemptive purpose to restore His image in them by making them holy as He is holy (Exod 31:13). As the need was universal, so too was the gift. ${ }^{96}$

Gane makes a similar observation when he notes that "unlike the other two Creation institutions [marriage and work], the Sabbath remains a little piece of Paradise.

\footnotetext{
${ }^{93}$ Christopher J. Donato, "Introduction," in Perspectives on the Sabbath, ed. Christopher J. Donato (Nashville: B\&H Academic, 2011), 3.

${ }^{94}$ Ibid.

${ }^{95}$ MacCarty, "The Seventh-day Sabbath," 11.

${ }^{96}$ Ibid., 14.
} 
As such, its value is enhanced by the deterioration around it." "97 "Now that work is exhausting, ceasing from labor on the Sabbath provides needed rest. More importantly, now that human beings are cut off from direct access to God, they need a reminder of his lordship even more than they did before the Fall. ${ }^{98}$

The appeals for Sabbath reform by the prophets and Jesus are strong indicators of the universal and permanent applicability of Sabbath observance as noted by MacCarty. And in response to a common objection that God specifically designated the Sabbath as a sign between Him and the nation of Israel exclusively, he argues as follows:

But that's just the point. The Sabbath was the covenant sign between God and Israel. And it was precisely with Israel that He made His new covenant! "This is the covenant I will make with the house of Israel after that time,' declares the Lord" (identical wording in Jer 31:33 and Heb 8:10, emphasis added), followed by God's description of the new covenant (Jer 31:33-34; Heb 8:10-12).

If you belong to Christ, then you are Abraham's seed, and heirs according to the promise' (Gal 3:29). All unbelievers who respond to the witness of God's new covenant "Israel" by putting faith in God and His Son Jesus, allowing His Spirit to make them a holy people manifesting an "obedience that comes from faith," will be incorporated into the covenant people, the true Israel of God. This brings new significance to God's statements that the Sabbath "will be a sign between me and the Israelites forever" (Exod 31:17). If the Sabbath applied exclusively to the ethnic nation of Israel, then so does the new covenant. However, just as the new covenant, which was specifically "for the house of Israel," applies to all "those who believe," then the Sabbath - which was God's chosen "sign" between Himself and Israel should likewise apply, universally and permanently to all "those who believe" (italics mine).

Roy Gane addresses the question of continuity and discontinuity as he examines

the role of the moral law, including Sabbath in the "new covenant." He states,

If we examine the crucial assumption that there is no continuity between the "Old" and "New" Testament covenants, we find that it is based on a

\footnotetext{
${ }^{97}$ Gane, "The Role of God's Moral Law," 13.

${ }^{98}$ Ibid.

${ }^{99}$ MacCarty, "The Seventh-day Sabbath," 61-62.
} 
misunderstanding of biblical proportions that fails to take sufficient biblical (including New Testament) evidence into account. When we look at the Bible in a more thorough and balanced way, we find that there is continuity as well as discontinuity: Cumulative phases of God's unified "everlasting covenant" bring wave upon wave of gracious divine initiative throughout Old Testament times and on into the New Testament, where the comprehensive culmination in the ultimate revelation and the only truly effective sacrifice of Jesus Christ washes over the human race with a tidal wave of grace ${ }^{100}$ (italics mine).

He notes that the function of law within the divine covenant phases, in addition to regulating behavior according to standards, is to protect human beings and their relationships, ${ }^{101}$ and then sets about to explain the place of the seventh day Sabbath within the traditional categories of biblical law ("moral," "ceremonial," "civil," and "health") which are not biblically explicit designations. He first defines and unpacks the "postbiblical analytical classifications"102 as follows: "Moral law expresses principles that modern people would regard either as religious (e.g., the first four of the Ten Commandments regarding responsibilities ... to God, Exod 20:3-11) or secular (e.g., the last six of the Ten Commandments covering responsibilities ... to human beings, 20:12-17."103

It is important to recognize that moral law is not limited to the Decalogue but applies to every word that proceeds from the mouth of God (Deut 8:3 and Matt 4:4). "Ritual law regulates a ritual system, by means of which human beings interact with entities that are ordinarily inaccessible to the material domain, such as God (e.g., by

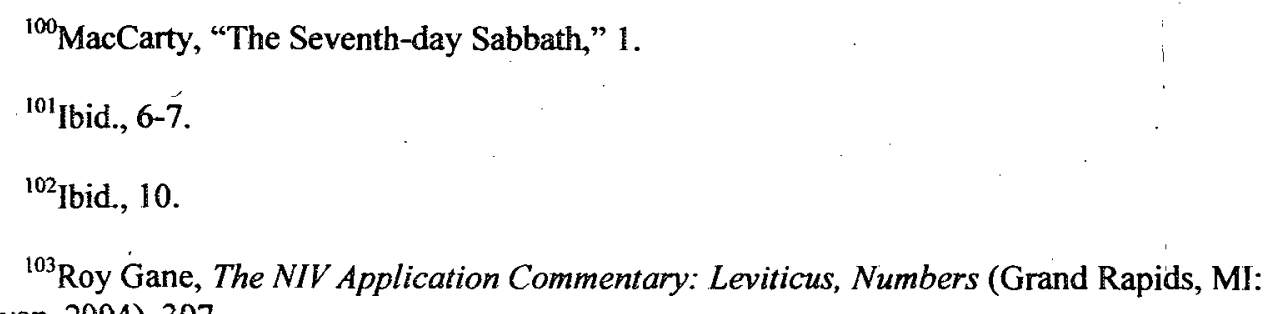
Zondervan, 2004), 307. 
offering sacrifices) and ritual purity (by removing it through purification)." ${ }^{\prime 04}$

Such laws are no longer binding based they were dependent on the sanctuary which is now non-existent. "Civil low can embody and exemplify timeless/moral/ethical principles within the ancient Israelite context. . . . So-called civil law contains both ongoing and temporal elements. ${ }^{105}$

Generally speaking, those aspects of civil law that are null and void today were dependent on institutions that have been done away with. However, timeless principles can still be gleaned from these laws despite the differences in cultural context, place, and the passing of time. "Pentateuchal laws for which we recognize health implications are consistently formulated with motivations other than health."106

It is plain to see that God's plan for blessing and benefiting His people always included a definite correlation between their health and their commandment-keeping as articulated in Exodus 15:26, Exodus 23:25, and Deuteronomy 7:15.

Gane also sets forth the criterion to determine the applicability of Old Testament law to be that "a biblical law should be kept to the extent that its principles can be applied unless the New Testament removes the reason for its application."107

Continuing, Gane makes the case for the importance of Sabbath observance as integral to the new covenant experience as demonstrated by Jesus as well as a compelling argument for logic in interpreting the motives for His Sabbath-related words and actions.

\footnotetext{
${ }^{104}$ Gane, The NIV Application Commentary, 307.

${ }^{105}$ Ibid., 308-309.

${ }^{106}$ Ibid., 309.

${ }^{107}$ Gane, Role of God's Moral Law, 9-10.
} 
"Just as God instituted the Sabbath at Creation by his example (Gen 2:2-3), Christ's example regarding reformation of Sabbath-keeping has prime relevance for Christians today." 108

The custom of Jesus to participate in corporate worship and His repeated efforts to be a corrective to the distorted interpretations and practices related to Sabbath as required by the ecclesiastical authorities of His day signify the importance of correct Sabbath observance. Gane asks, "Why would he restore something that he was about to do away with? That would make as much sense as remodeling a house before demolishing it! Furthermore, why would he wipe out the seventh day Sabbath when his covenant lordship over it was part of his divine messianic claim?"'109

Additionally, Gane provides greater understanding of both the "old covenant" and the "new covenant" by declaring that "while the "new covenant' ratified by Christ's own blood culminates God's initiative to restore an intimate relationships with human beings, it fulfills God's long-range plan rather than radically repealing everything that had gone before."110

It is also worthy of note that the gospels, written long after the crucifixion and resurrection of Christ, would not have emphasized the Sabbath reforms instituted by Jesus if the Sabbath was done away with.

Further, Mathilde Frey concludes that "the use of an unusual expression [in the Sabbath commandment in the book of the covenant (Exod 23:12)] indicating work during

\footnotetext{
${ }^{108}$ Gane, Role of God's Moral Law, 18.

${ }^{109}$ Ibid.

${ }^{110}$ Ibid., 19.
} 
the six days of the week connects the Sabbath to creation and thus highlighting its universal dimension." 111

The evidence of the permanent and universal applicability of Sabbath observance includes the fact that the Sabbath originated at the end of Creation week, prior to sin, and has always been the great gift and opportunity provided by the Creator and Lord of the Sabbath for His people to be with Him and to made holy.

\section{Summary and Conclusions}

After an examination of scriptural content and context for Sabbath observance from the Pentateuch, Historical Literature, Psalms, Prophets, Gospels, Actș, and Epistles, an overview of the theological perspectives of selected Seventh-day Adventist Christian biblical scholars and authors on Sabbath observance, based on the same biblical sources, has ensued.

Unequivocally, the Scriptures provide evidence and descriptions of Sabbath observance as well as indicators of the universal and permanent applicability of Sabbath observance. MacCarty rightly states that "God called Isaiah, and anyone who joined his reform movement, a 'Repairer of Broken Walls' ('Repairer of the Breach,' Isa 58:12 NKJV, NSRV)," 112 and as such, issues a clarion call to make known the good news of thị gift to everyone everywhere.

\footnotetext{
${ }^{111}$ Frey, "The Sabbath Commandment," 3.

${ }^{112}$ MacCarty, "The Seventh-day Sabbath," 18.
} 


\section{CHAPTER 3}

\section{LITERATURE REVIEW}

\section{Introduction}

In his landmark theological study of the Sabbath, Divine Rest for Human Restlessness, Samuele Bacchiocchi shows "that the Sabbath does enable the Savior to bring perfect rest to our lives by offering us the opportunity to experience the rest of creation, the rest of divine presence, the rest of belonging, the rest from competition, the rest from social tensions, the rest of redemption, and the rest of service" (italics supplied).

But "the sense of disillusionment, emptiness, álienation and meaninglessness experienced by many modern thinking individuals"2 seems to characterize far too many postmodern-thinking African American Oakwood University students whose knowledge, practices, and attitudes/feelings regarding Sabbath and Sabbathkeeping do not reflect the holistic celebration of the Good News of the Sabbath "that the Lord has created us perfectly, that $\mathrm{He}$ has redeemed us completely, that $\mathrm{He}$ loves us immensely, and that $\mathrm{He}$ will restore us ultimately."3

\footnotetext{
'Samuele Bacchiocchi, Divine Rest for Human Restlessness (Berrien Springs, MI: Biblical Perspectives, 1988), 226.

${ }^{2}$ Ibid., 19.

${ }^{3}$ Ibid., 226.
} 
Richard Osmer provides the theoretical framework for this project and states that the Pastoral Cycle or "practical theological interpretation involves four key tasks: the descriptive-empirical, the interpretive, the normative and the pragmatic." ${ }^{.4}$ In this chapter which has the Interpretive Task of the Pastoral Cycle to provide social analysis, we will review current literature that draws on theories of the arts and sciences to better understand why these patterns and dynamics are occurring. This will include recent research on the subjects of spiritual formation (including spirituality and spiritual development); spiritual formation courses (within the context of religious and theological education); the relationship of spiritual formation and spiritual formation courses to college and university students in general; the relationship of spiritual formation and spiritual formation courses to African American college and university students; the influence of spiritual disciplines on college and university students; the influence of spiritual disciplines on African American college and university students; the influence of the spiritual discipline of Sabbathkeeping in general; the influence of the spiritual discipline of Sabbathkeeping on college and university students; and the influence of the spiritual discipline of Sabbathkeeping on African American college and university students.

As the research question for this dissertation is "How does a spiritual formation course influence the perspectives of African American Oakwood University students on Sabbath and Sabbathkeeping as a spiritual discipline?" the researcher has chosen the working definition of "perspective" to be "the capacity to view things in their true

\footnotetext{
${ }^{4}$ Osmer, Practical Theology: An Introduction, 10.
} 
relations or relative importance." The perspective of the researcher has necessarily required the capacity to view the stated research question in its true relation or relative importance to the postmodern era in which the study is undertaken.

Therefore several definitions, interpretations and implications of postmodern and postmodernism are now offered as contextual undergirding for the review of literature to follow, particularly as they relate to spirituality, spiritual formation and religious or theological education where spiritual formation courses are situated.

\section{Postmodern/Postmodernism: Definitions, Interpretations, and Implications}

"In an age of increased pluralism, increased antipathy toward organized religion, decreased trust in institutions, and decreased respect for public authority," position of Susanne Johnson that "postmodernity itself is not a monolithic term or movement. It is, rather, a collective label for basic shifts in values and in attitudes in American culture, widespread enough to be called a paradigm shift. ${ }^{7}$

For some, postmodernism is characterized by "valuing multiple ways of knowing, ${ }^{8}$ while for others it is "the name most often used to refer to the nascent

\footnotetext{
${ }^{5}$ Webster's Seventh Collegiate Dictionary (1971 ed.), s.v. "Perspective."

${ }^{6}$ Susanne Johnson, "Christian Spiritual Formation in an Age of 'Whatever,"' Review and Expositor 98 (Summer 2001): 309.

${ }^{7}$ Ibid.

${ }^{8}$ Mark R. McMinn and Todd W. Hall, "Christian Spirituality in a Postmodern Era," Journal of Psychology and Theology 28, no. 4 (2009): 252.
} 
rejection of crass materialism and the positive revaluation of spiritual and human values in society."9

Anglican Abbess Karen Ward characterizes the postmodern turn (the massive shift that has happened in how people view and navigate the world) by contrasting and comparing it to what had been previously considered normative.

We have moved beyond the Enlightenment era and its credo of "science, progress, truth, and reason," and into a new world in which life is not better, truth is relative, diversity is normal, objectivity is mythical, science can't save us, power is distributed, hierarchy is flattened, knowledge is networked, life is chaotic, reality bites, mystery happens, and reason is highly overrated. ${ }^{10}$

America's leading pollster, George Gallup Jr., in his collaboration with spiritual life specialist, Timothy Jones, cites five signposts for the next American spirituality, including a search for roots amid the relativism [of postmodernism].

Related to the interest in experience is our culture's alignment with postmodernism. American culture imbibes deeply from the movement, a loose philosophical stream variously (and often vaguely) defined). Among postmodernism's tenets is the assumption that truth in a final sense is unknowable. Absolute truth has instead gone the way of prescientific, tribal cultures. Inevitably, it claims, the observer contaminates the pursuit of truth through the relativity of his or her experience. What we can know must always be conditioned by the limits of our context and upbringing. ${ }^{11}$

It is through these lenses, then, that the literature regarding the influence of a spiritual formation course on African American Oakwood University students on Sabbath and Sabbathkeeping as a spiritual discipline must be viewed.

${ }^{9}$ William Loyd Allen, "Editorial Introduction: Christian Spirituality in the Age of Growing Secularity," Perspective in Religious Studies 31, no. 1 (Spring 2004): 5.

${ }^{10} \mathrm{Karen}$ M. Ward, "Back to the Future: Visionary, Entrepreneurial, Missional Anglican Leadership for Today's Church," Anglican Theological Review 92, no. 1 (Winter 2010): 168.

${ }^{11}$ George Gallup Jr. and Timothy Jones, The Next American Spirituality: Finding God in the Twenty-first Century (Colorado Springs, CO: Cook Communications, 2000), 56-57. 


\section{Spiritual Formation}

Overview of Nomenclature: Designations, Definitions, and Distinctions

The language and vocabulary for expressing growth and maturation in the spiritual realm include but are not limited to such terminology as "spirituality," "moral development," "faith development," "spiritual development," and "spiritual formation." Thus it is prudent to examine the definitions provided in the most recent research of these concepts so as to insure clarity regarding this overarching framework for what is sometimes also referred to in Christian circles as biblical spirituality. In the citations to follow, secular or self-referenced understandings of spirituality are distinguished from Christian and Seventh-day Adventist or Christ-centered and biblically based definitions of spirituality:

\section{Spirituality vs. Religion}

In the groundbreaking comprehensive resource that addresses the growing movement for incorporating spirituality as an important aspect of the meaning and purpose of higher education, Arthur Chickering, Jon Dalton, and Liesa Stamm differentiate between religion and spirituality "with the term religion encompassing affiliation with and practice of an established denominational tradition and spirituality marked by a highly personal search for ultimate meaning, purpose, and values wherever they may be found." 12

Nicholas Bowman and Jenny Small explored the relationship between privileged religion and spiritual development among 14,527 college students from 136 public and

\footnotetext{
${ }^{12}$ Arthur W. Chickering, Jon C. Dalton, and Liesa Stamm, Encouraging Authenticity and Spirituality in Higher Education (San Francisco: Jossey-Bass, 2006), 38.
} 
denominationally-affiliated institutions, defining spirituality and spiritual as "core beliefs about the sacred"13 and religion and religious as "the actions and affiliation surrounding that core, typically occurring within an institutional body."

\section{Self-referenced Spirituality}

Professor at Seattle University, Sharon Daloz Parks, who holds a doctoral degree in theology and human development, comments on a recognition of spirituality and an acknowledgement of the soul in the corporate and educational spheres. "[It is] rooted in a longing for ways of speaking of the human experience of depth, meaning, mystery, moral purpose, transcendence, wholeness, intuition, vulnerability, tenderness, courage, the capacity to love, and 'apprehension of spirit (or Spirit) as the animating essence at the core of life." $" 14$

Provost and vice president for academic and student affairs at Austin Peay State University, Bruce Speck researched this subject and concluded that "definitional dilemmas are rife in the literature on spirituality in higher education." ${ }^{\text {15 }} \mathrm{He}$ found:

- Basically, it [spirituality] is the living out of the organizing story of one's life. In this definition, everyone has a spirituality. The organizing stories of our lives turn around to that which we are ultimately loyal and which we trust for our fulfillment [Bennett, 2003, p. xiii].

- Spirituality is the experience of the transcendent, or the quality of transcendence, something that welcomes, but does not require, religious beliefs [Bento, 2000, p. 653]

- Spirituality is the place in our hearts that holds all of the questions about our purpose in the world and it is reflected in our actions [Campbell, 2001, p. 20].

\footnotetext{
${ }^{13}$ Nicholas A. Bowman and Jenny L. Small, "Do College Students Who Identify with a Privileged Religion Experience Greater Spiritual Development?" Research in Higher Education 51 (2010): 596.

${ }^{14}$ Sharon D. Parks, Big Questions, Worthy Dreams: Mentoring Emerging Adults in Their Search for Meaning, Purpose, and Faith (San Francisco: Jossey-Bass, 2011), 16.

${ }^{15}$ Bruce Speck, “What Is Spirituality?" New Directions for Teaching and Learning 104 (2005): 11.
} 
- Spirituality refers to that noncorporal aspect of each human being that is separate from the mind. Religion refers to an organized set of doctrines around faith beliefs within an organization [Clark, 2001, p. 38].

- Spirituality can be understood as the ability to experience connections and to create meaning in one's life [Fried, 2001, p. 268]

- Spirituality is the inner experience of the individual when he or she senses a beyond, especially as evidenced by the effect of this experience on his or her behavior when he or she actively attempts to harmonize his or her life with the beyond [Lewis and Geroy, 2000, p. 684]

- By spirituality I mean a sense of compassion; nonviolence, truthfulness, loving kindness, being connect to the whole, and living a simple, peaceful harmonious life [Massoudi, 2003, p. 118].

- Spirituality is the pursuit of a trans-personal and trans-temporal reality that serves as the ontological ground for an ethic of compassion and service [Mayes, 2001, p. 6]

- Spirituality is the eternal human yearning to be connected with something larger than our own egos [Palmer, 2003, p. 377]. ${ }^{16}$

Further, Speck suggests three points of tension in the literature on spirituality in higher education that have contributed to the definitional dilemma: "separation of church and state, the reigning epistemology of higher education and lack of faculty education in addressing spirituality."17

Elizabeth Tisdell, professor of Education at Penn State University, representing an inclusive conception of spirituality that is growing more prevalent, adds that "spirituality defines how people construct knowledge through meaning-making and awareness of wholeness and the interconnectedness of all things, including unconscious and symbolic processes." honor as sacred in our lives." 19

\footnotetext{
${ }^{16}$ Speck, "What Is Spirituality?" 3-4.

${ }^{17}$ Ibid., 5.

${ }^{18}$ Elizabeth Tisdell, Exploring Spirituality and Culture in Adult and Higher Education (San Francisco: Jossey-Bass, 2003), 20.

${ }^{19}$ Ibid., 29.
} 
James W. Fowler, former developmental psychologist at the Candler School of Theology, augmented the six stages of "faith development theory" from his 1981 publication that closely relate to Lawrence Kohlberg's moral development theory and proposed in 2001, "a theory of four types of spirituality that crosscut stages rather than replace them."20

The Totalizing Type, often found in members of Fundamentalist groups, demonstrates an emotional rigidity combined with a legalistic spirit where the locus of authority rests in leaders, creeds, or ideologies. The Rational Type has a clear conviction that is open to questions and discussion. Other sources of authority are examined as well. The Conflicted or Oscillating Type is the restless, "existential seeker of truth" who has lost connection with early faith relationships and is seeking intellectual and moral integrity in a difficult world. The Diffuse Type has a fragmented, incoherent, or nonintegrated quality that causes drifting with "limited capacity for intimacy and commitment. $^{21}$

According to Jennifer Lindholm, Director of the Spirituality in Higher Education

project at the University of California in Los Angeles,

One of the most notable findings from a survey we administered in fall 2004 to 112,232 entering first-year college students at 236 campuses nationwide is that today's incoming students place significant personal emphasis on matters related to the interior dimension of their lives. 22

Knowing that spirituality plays a key role in the daily life of entering college students, we gained additional insight into their personal conceptions of spirituality by interviewing second-, third-, and fourth-year undergraduates. In keeping with characterizations commonly noted in the literature, those with whom we talked most often conceptualized spirituality in terms of people's "ultimate beliefs," "morals," or "philosophy of life," a core "part of who you are" and the "values you live by."

Inherent in most students' constructions was a largely self-focused element, a sense that spirituality is an "individual thing" with strong components of "self-reflection" and "internal conversation." Others conceived of spirituality in terms of "what you're experiencing from the world and how you process that and sent that back out into the

\footnotetext{
${ }^{20}$ James W. Fowler, "Faith Development Theory and the Postmodern Challenges," The International Journal for the Psychology of Religion 1, no. 3 (2001): 169.

${ }^{21}$ Ibid., 170.

${ }^{22}$ Jennifer A. Lindholm, "Spirituality in the Academy: Reintegrating Our Lives and the Lives of Our Students," About Campus (September-October 2007): 10.
} 
world." While an individualistic theme was prominent, there was also a strong, commonly expressed sentiment that one's individual connection with spirituality has important implications for relating to others. Equally equivalent was the notion that spirituality is heavily process-oriented and tightly linked with "asking questions about who you are and what you believe.,23

Cultivating the Spirit, the groundbreaking, five-year study on the spiritual growth of college students, includes summative assessments of spiritual and religious qualities. Addressing the issue of "Why Spirituality Matters" in chapter one, the research team of Alexander Astin, Helen Astin, and Jennifer Lindholm immediately set forth an extended explanation of what they mean by "spirituality."

Spirituality points to our inner, subjective life, as contrasted with the objective domain of observable behavior and material objects that we can point to and measure directly. Spirituality also involves our affective experiences at least as much as it does our reasoning or logic. More specifically, spirituality has to do with the values we hold most dear, our sense of who we are and where we come from, our beliefs about why we are here - the meaning and purpose that we see in our work and our life - and our sense of connectedness to one another and to the world around us. Spirituality can also bear on aspects of our experience that are not easy to define or talk about, such things as intuition, inspiration, the mysterious, and the mystical. Finally, we believe that highly "spiritual" people tend to exemplify certain personal qualities such as love, compassion, and equanimity. ${ }^{24}$

Their analyses include assessments of spiritual and religious qualities and identified internally- and externally-directed aspects of development. The measures of spirituality encompass spiritual quest, equanimity, ethic of caring, charitable involvement, and ecumenical worldview, while the measures of religiousness are religious commitment, religious engagement, religious/social conservatism, religious skepticism, and religious struggle. ${ }^{25}$

\footnotetext{
${ }^{23}$ Lindholm, "Spirituality in the Academy," 12.

${ }^{24}$ Alexander W. Astin, Helen S. Astin, and Jennifer A. Lindholm, Cultivating the Spirit: How College Can Enhance Students' Inner Lives (San Francisco: Jossey-Bass, 2011), 4.

${ }^{25}$ Ibid., 20-22.
} 
Robert Nash and Michele Murray explore the quest of college students to find meaning in religion and spirituality and offer a practical guide for the entire campus community. Asserting that the cry for spiritual meaning is everywhere, they define spirituality to mean "a penchant, probably hard-wired into all humans to ponder the imponderable, to ask the unanswerable questions about the meaning of life, especially its omnipresent, unavoidable pain, suffering, and death-conditions that paradoxically coexist with life's unalloyed joys, pleasures, and satisfactions. ${ }^{26}$

\section{Christ-centered Biblical Spirituality}

With few exceptions, it appears that researchers and practitioners have determined that the essence of spirituality is self-exploration and that self-knowledge is tantamount to spirituality. David Hindman, director of the Wesley Foundation at the College of William and Mary, however, portends that such understanding of spirituality "carries with it the possibility that not all spiritualities are the same, or even beneficial ... not all spirits are of God; nor does every spirituality enhance life for self or others. ${ }^{, 27}$ Necessary for inclusion are definitions of Christian spirituality that center the nature of that which is spiritual in God as revealed in Christ and the person and ministry of the Holy Spirit.

McMinn and Hall offer research that addresses the polarization that has developed in which spirituality tends to be viewed as individually oriented and good, and religion tends to be viewed as institutional and bad. They assert that the concept has become

\footnotetext{
${ }^{26}$ Robert M. Nash and Michele C. Murray, Helping College Students Find Purpose: The Campus Guide to Meaning-Making (San Francisco: Jossey-Bass, 2010), 53-54.

${ }^{27}$ David M. Hindman, "From Splintered Lives to Whole Persons: Facilitating Spiritual Development in College Students," Religious Education 97, no. 7 (Spring 2002): 168-169,
} 
rather amorphous and difficult to define in our postmodern context with some even arguing that spirituality is defined by its lack of definition. But they take the position that "a spirituality that is bounded by historic Christian theology defies a postmodern pluralism and asserts truth claims about the nature of God, normative notions of human development and maturity, and the methods involved in the search for God and spiritual growth.",28

Robert M. Franklin, former president of the Interdenominational Theological Center, developed a general typology for African American spirituality in his book Another Day's Journey. Seven spiritual traditions of black churches are delineated here:

\begin{tabular}{|c|c|c|c|}
\hline Spirituality Tradition & Spiritual End & Spiritual Disciplines & Spiritual Exemplar \\
\hline Evangelical & $\begin{array}{l}\text { Knowledge of } \\
\text { God's Word }\end{array}$ & $\begin{array}{l}\text { Teaching, preaching, } \\
\text { study }\end{array}$ & William Bentley \\
\hline Holiness & $\begin{array}{l}\text { Purity of life and } \\
\text { thought }\end{array}$ & $\begin{array}{l}\text { Fasting, prayer, } \\
\text { renunciation }\end{array}$ & Arenia Mallory \\
\hline Charismatic & $\begin{array}{l}\text { Empowerment via } \\
\text { the Holy Spirit }\end{array}$ & $\begin{array}{l}\text { Tarrying, seeking } \\
\text { spiritual gifts }\end{array}$ & William Seymour \\
\hline Social Justice & $\begin{array}{l}\text { Public } \\
\text { Righteousness }\end{array}$ & $\begin{array}{l}\text { Community activism, } \\
\text { political activity }\end{array}$ & Vernon Johns \\
\hline Afrocentric & $\begin{array}{l}\text { Celebration of } \\
\text { black identity }\end{array}$ & $\begin{array}{l}\text { Cultural displays of } \\
\text { African heritage }\end{array}$ & George McGuire \\
\hline Contemplative & $\begin{array}{l}\text { Intimacy with } \\
\text { God }\end{array}$ & $\begin{array}{l}\text { Prayer, } \\
\text { meditation }\end{array}$ & Howard Thurman \\
\hline New Age & Peace of mind & $\begin{array}{l}\text { Meditation, } \\
\text { chanting music }\end{array}$ & Dionne Warwicke \\
\hline
\end{tabular}

Figure 2. Seven spiritual traditions of black churches

\footnotetext{
${ }^{28}$ McMinn and Hall, "Christian Sṕirituality in a Postmodern Era," 252.

${ }^{29}$ Robert M. Franklin, Another Day's Journey (Minneapolis, MN: Fortress Press, 1997), 41-43.
} 
It can be argued that the richest African American congregations embody at least the first six of these historical and contemporary traditions of spirituality.

For Kenneth Boa, president of Reflections Ministries and Trinity House Publishers, biblical spirituality is a like a multi-faceted gem that define spiritual formation but is greater than the sum of its parts. He defines it as "a Christ-centered orientation to every component of life through the mediating power of the indwelling Holy Spirit." ${ }^{30}$

Author and retired professor of theology and spiritual formation, Bruce Demarest, distinguishes Christian spirituality by the key characteristic of Christ-centeredness. He writes, "The fullness of life we crave is found only in heart-to-heart relationship with Christ, in growing in His character, and in being directed by His Spirit." ${ }^{\text {31 }}$

The starting point for Mark Maddix, Dean of the School of Theology at Northwest Nazarene University, is the theological supposition that "human beings are spiritual beings with the capacity, by God's grace, to experience Him." ${ }^{32}$ For him, "to speak of something being spiritual assumes the existence of a transcendent reality...and then argues further that we humans can and do experience this reality in our midst and that we are drawn to both name and respond to it.",33

\footnotetext{
${ }^{30}$ Kenneth Boa, Conformed to His Image: Biblical and Practical Approaches to Spiritual Formation (Grand Rapids, MI: Zondervan, 2001), 19.

${ }^{31}$ Bruce Demarest, Satisfy Your Soul: Restoring the Heart of Christian Spirituality, quoted by Evan Howard, "Three Temptations of Spiritual Formation," Christianity Today 46, no. 13 (2002): 48.

${ }^{32}$ Mark A. Maddix, "Spiritual Formation and Christian Formation," Christian Formation: Integrating Theology and Human Development, ed. James Estep and Jonathan Kim (Nashville: B\&H Publishing Group, 2010), 239.

${ }^{33} \mathrm{Ibid}$.
} 
Mark Maddix refers to Christian spirituality as "a particular way of responding to the Spirit of God - mediated to the world and ultimately known through Jesus Christ. ${ }^{\text {34 }}$ And for Donald Bloesch, professor theology emeritus at Dubuque Theological Seminary, spirituality in the Christian sense "is not so much an upward progression nor an inward possession. Instead, it is an outward succession - following Christ into the darkness of the world, letting the light of the gospel shine in our words and in our actions."35

\section{Seventh-day Adventist Christian Views} of Spirituality

One of the founders of the Seventh-day Adventist church, Ellen G. White, not only described but encouraged spirituality. "The attributes of God are goodness, mercy, love, long-suffering and patience, and his followers are to possess the same attributes of character representing Christ in true spirituality." ${ }^{36}$

In 1869 in a letter to a member, she wrote, "Train your thoughts so that it will be easy for them to dwell upon pure and holy things. Cultivate a love for spirituality and true godliness."37

In his doctoral dissertation on "Holistic Spirituality in the Thinking of Ellen White," Harri Kuhalampi studied the key terms associated with personal religion in six of White's books, written between 1892 and 1905, such as "love of God," "union with Christ," "surrender to God," "helplessness," "human spirit," "character," "dependence,"

${ }^{34}$ Maddix, "Spiritual Formation and Christian Formation," 240.

${ }^{35}$ Donald G. Bloesch, Spirituality Old and New: Recovering Authentic Spiritual Life (Downers Grove, IL: InterVarsity Press, 2007), 14.

${ }^{36}$ Ellen G. White, Signs of the Times, August 22, 1895.

${ }^{37}$ Ellen G. White, Testimonies for the Church (Mountain View, CA: Pacific Press, 1948), 2:315. 
"cooperation," "grace," "prayer," "will," "consecration," and "usefulness." $\mathrm{He}$

concludes,

White connects her thoughts on a healthful lifestyle and education to a broad understanding of spirituality which aims for the person's holistic welfare. She does not see spirituality as insular, cut off from the day-to-day business of life, but rather as the primary dimension which energises, gives purpose and guides a person in all aspects of life.

During the course of the study the concepts "surrender to God" and "character", frequently used by White, became a focus of attention. According to White, a person cannot reach God alone, by an effort of the will; instead, when faced with God's loving invitation, one must cease to will for oneself and agree to unite with God's will and purpose. This is connected to the internal change which White describes by the concept of character. The new orientation of the will, accomplished by God's grace, changes the person's being, values, attitudes and ability for sympathetic interaction to such an extent that the person is no longer quite the same as before. There is, on the other hand, a sudden and total change of being, but at the same time a quiet, life-long growth and development are intended. It is through the concept of character that White describes spirituality and the inner journey it entails. ${ }^{38}$

As a result of the debate in the late twentieth century and early twenty-first century regarding the teaching of courses in spiritual formation in Seventh-day Adventist universities and colleges, the dean and faculty of the seminary at Andrews University have developed a statement on biblical spirituality that opens with the scriptural references (1 Cor 1:30; Col 1:27;2 Cor 3:18) to the necessity of transformation. It begins by asserting their belief that "the greatest and most urgent of all our needs is a revival of true godliness, which is true biblical spirituality, or having Christ formed in us by the Holy Spirit."39

The document includes principles of biblical spirituality, personal practices of biblical spirituality, and dynamics of biblical spirituality, concluding with the definition

\footnotetext{
${ }^{38}$ Harri Kuhalampi, Holistic Spirituality in the Thinking of Ellen White (Unpublished doctoral dissertation, University of Helsinki, 2010), 8.

${ }^{39}$ Denis Fortin et al., "A Statement on Biblical Spirituality," 1, www.andrews.edu/sem/sdats bibspir.pdf (accessed May 15, 2012).
} 
of biblical spirituality as "a life of discipleship intentionally lived in a personal relationship with God through Christ by the Spirit ... [including] conversion, justification, and sanctification. .40

With regard to teaching biblical spirituality at the Seventh-day Adventist Theological Seminary, in an online letter posted on the homepage of the seminary website, Dean Fortin explains the reason for the courses and rationale for the change in nomenclature as follows:

The intent of spiritual formation is to teach students what Scripture says about living a genuine life of commitment to God, to be open to the convictions of the Holy Spirit, to be regenerated in Christ. Spiritual formation is an academic term used to describe courses or subjects that deal with spiritual development and faith nurture. By using the term we are saying that we offer biblically-based classes that focus on the spiritual lives of our students. And shouldn't we do more, not less, of this kind of faith nurture? Yet, to avoid any further confusion, we have decided to change the name of our courses to refer instead to biblical spirituality. We hope this will help alleviate some genuine concerns people have had. ${ }^{41}$

Jon Dybdahl, former college president and seminary professor, maintains that true spirituality can be recognized by its fruits; among which are a sense of divine presence or nearness, joy and celebration, growth and service. ${ }^{42}$

\section{Spiritual Formation vs. Spiritual Development}

While this research project seeks to understand the influence of a spiritual formation course, it is appropriate to acknowledge that "formation" and "development" have similar connotations. Consequently, spiritual formation or spiritual development

\footnotetext{
${ }^{40}$ Fortin et al., "A Statement on Biblical Spirituality," 11.

${ }^{4 i}$ Denis Fortin, "Teaching Biblical Spirituality," www.andrews.edu/sem/response/html (accessed
} May 15, 2012).

${ }^{42}$ Jon L. Dybdahl, Hunger: Satisfying the Longing of Your Soul (Hagerstown, MD: Review and Herald, 2008), 133-134. 
must be situated within the context of human developmental theories. A recapitulation of key theorists and their postulations that have shaped the study of human life cycles will suffice for the purposes of this endeavor.

\section{Theories of Human Development}

Human Development and Faith: Life-Cycle Stages of Body, Mind, and Soul by Felicity B. Kelcourse introduces a multidisciplinary perspective of human development and categorizes theories of human development into three groups: depth psychologies, theories of cognitive development, and family systems theories. ${ }^{43}$

Depth psychologies include the contributions of Sigmund Freud and psychoanalysis; Carl Jung and analytical psychology; object relations theory and ego psychology in the works of Melanie Klein, Anna Freud, Donald Woods Winnicott, and Margaret Mahler; Erik Erikson's stage theory as well as self psychology; and intersubjectivity primarily in the work of Heinz Kohut.

Cognitive, structural, and constructive theories of development are attributed to Jean Piaget and cognitive development; Lawrence Kohlberg and the development of moral reasoning (Level 1-Preconventional Morality covers Stage 1: Obedience and Punishment Orientation and Stage 2: Individualism and Exchange; Level 2Conventional Morality covers Stage 3: Good Interpersonal Relationships and Stage 4: Maintaining Good Order; and Level 3-Postconventional Morality covers Stage 5: Social Contract and Individual Rights and Stage 6: Universal Principles) ${ }^{44}$; Carol Gilligan (who

\footnotetext{
${ }^{43}$ Felicity B. Kelcourse, ed., Human Development and Faith: Life-Cycle Stage of Body, Mind, and Soul (St. Louis, MO: Chalice Press, 2004), 59-90.
} 
argues that the schemes of Freud, Erikson, Piaget, and Kohlberg are distorted by the choice of subjects [white upper-class males] and that the inclusion of the female voice would offer the alternative of viewing moral problems as conflicting responsibilities requiring care, rather than competing rights requiring rules of justice for resolution) ${ }^{45}$; James Fowler's structure of faith development (Infancy and Undifferentiated Faith; Intuitive-Projective Faith; Mythic-Literal Faith; Synthetic-Conventional Faith; Individuative-Reflective Faith; Conjunctive Faith; and Universalizing Faith) ${ }^{46}$; and Robert Kegan's constructive-developmental theory.

Although the studies of William Perry on cognitive and ethical development in college students occurred from 1954 to1963, his identification of nine positions, grouped into the three sequential categories of dualism, multiplicity, and commitment, is helpful in providing an important reference point for later discussion of V. James Mannoia's concept of critical commitment and developmental curricula. His summaries of his positions of cognitive development follow to articulate the essence of these designations from the perspective of the student.

Dualism

Position 1: Basic duality = The student sees the world in polar terms of we-right-good vs. other-wrong-bad. Answers for everything exist in the Absolute, known to Authority whose role is to teach them.

Position 2: Multiplicity - prelegitimate $=$ The student perceives diversity of opinion and uncertainty and accounts for them as unwarranted confusion in poorly qualified

\footnotetext{
${ }^{44}$ Daniel K. Lapsley, "Moral Stage Theory," in Handbook of Moral Development, ed. Melanie Killen and Judith Smetana (Mahwah, NJ: Lawrence Erlbaum Associates, 2006), 45-52.

${ }^{45}$ Carol Gilligan, In a Different Voice: Psychological Theory and Women's Development (Cambridge, MA: Harvard University Press, 1982), 19.

${ }^{46}$ James W. Fowler, Stages of Faith: The Psychology of Human Development and the Quest for Meaning (New York: HarperCollins Publishers, 1981), 117-211.
} 
Authorities or as mere exercises set by Authority "so we can learn to find The Answer for ourselves."

Position 3: Multiplicity - subordinate $=$ The student accepts diversity and uncertainty as legitimate but still temporary in areas where Authority 'hasn't found The Answer yet." The student is puzzled by how teachers can assign grades.

\section{Multiplicity}

Position 4: Relativism subordinate/multiplicity correlate $=$ Depending on whether the student follows a path of adherence (assimilation) or opposition (accommodation) to Authority, either relativism becomes just a special case of "what they want" or a legitimate correlate domain alongside dualism, in which "anyone has a right to his own opinion" and "no one can tell me I'm wrong."

Position 5: Relativism (competing, correlate or diffuse) $=$ The student perceives all knowledge and values, including authority's, as contextual and relativistic. They subordinate "dualistic right-wrong functions to the status of a special case" of relativism instead of the other way around as in position 4 . A revolution has occurred.

Position 6: Commitment foreseen $=$ The student apprehends the necessity of orienting himself in a relativistic world through some form of personal Commitment (as distinct from unquestioned or unconsidered commitment to simple belief in certainty).

Commitment

Position 7: Initial commitment $=$ The student makes an initial Commitment in some area.

Position 8: Orientation of commitment implications $=$ The student experiences the implications of Commitment and explores the ... issues of responsibility.

Position 9: Developing commitment $=$ The student experiences the affirmation of identity among multiple responsibilities and realizes Commitment as an ongoing unfolding activity through which he expresses his lifestyle. ${ }^{47}$

Perry viewed positions 4,5 , and 6 as the critical ones in the college years and the

\footnotetext{
${ }^{47}$ William G. Perry, Forms of Intellectual and Ethical Development in the College Years (New York: Holt, Rhinehart \& Winston, 1970), 9-10.
} 
transition from position 4 to 5 as perhaps the most crucial. ${ }^{48}$

Finally, as we proceed to consider theories of spiritual development, it is of interest that New Testament scholar, M. Robert Mulholland, likens spiritual development to human development in that each is defined by a gradual, lifelong process. ${ }^{49}$

\section{Theories of Spiritual Development}

Psychiatrist M. Scott Peck suggests a four-stage theory of spiritual development the constituent parts of which are the chaotic, antisocial stage; the formal, institutional stage; the skeptical, individualization stage; and the communal mystical stage. ${ }^{50}$

\section{Spiritual development is described in M. Robert Mulholland's Invitation to a}

Journey: The Road Map to Spiritual Formation as the classical spiritual pilgrimage which includes the stages of awakening, purgation, illumination, and union. ${ }^{51}$

The six stages in the life of faith as articulated in The Critical Journey by author and social activist Janet Haberg and New Testament scholar Robert Guelich begin with recognition of God and end with a life of love. ${ }^{52}$

The Minneapolis-based Search Institute research team of Peter L. Benson, Eugene C. Roehlkepartain, and Stacey P. Rude advance a definition of spiritual development as the process of growing the intrinsic human capacity for self-transcendence, in which the self is embedded in something greater than the self, including the sacred. It is the developmental "engine that propels the search for connectedness, meaning, purpose,

${ }^{48}$ Perry, Forms of Intellectual and Ethical Development, 214-215.

${ }^{49}$ Mulholland, Invitation to a Journey, 21.

${ }^{50} \mathrm{M}$. Scott Peck, The Different Drum (New York: Simon and Schuster, 1987), 186-208.

${ }^{51}$ Mulholland, Invitation to a Journey, 80-81.

${ }^{52}$ Janet O. Hagberg and Robert Guelich, The Critical Journey: Stages in the Life of Faith (Salem, WI: Sheffield Publishing Company, 2005), 31-160. 
and contribution. It is shaped both within and outside of religious traditions, beliefs and practices. ${ }^{53}$

The notion of spiritual development adds an important dimension to an exploration of spirituality. Spiritual development introduces a focus on spiritual change, transformation, growth or maturation. ${ }^{54}$

"Splintered lives" is the metaphor Hindman uses to describe the painful fragmentation that results from the lack of or deficiency in spiritual development and addresses the means by which faith can be nurtured.

Students must have an image of a whole life. They must be able to see that image take shape in a real human being, such as faculty or staff. They must have the opportunity to imagine possibilities for who they may become, given the talents and gifts they possess. They must be able to see themselves as having a place in a larger story which gives meaning and shape to life. ${ }^{55}$

Those who wish to assist in developing the spirituality of students will enable them to pay a visit on themselves in order to explore deeply who they are and their sense of self and vocation.... Development in spirituality occurs as students are helped to deepen their awareness of the sanctity of their own lives in the here and now. Spiritual growth happens as they explore who they are and what they do as true expressions of spirit, values, and commitment. Spiritual maturity brings together the fragmented, splintered aspects of life to address questions of who I am and what I am to know, to do and to be. ${ }^{56}$

Sharon Daloz Parks, like Fowler before her, speaks of faith development as opposed to spiritual development and presents a model of three interacting components. She describes them as "forms of knowing (cognitive aspects of faith development), forms

\footnotetext{
${ }^{53}$ Peter L. Benson, Eugene C. Roehlkepartain, and Stacey P. Rude, "Spiritual Development in Childhood and Adolescence: Toward a Field of Inquiry," Applied Developmental Science 7, no. 3 (2003): 205-206.

${ }^{54}$ Ibid., 210.

${ }^{55}$ Hindman, "From Splintered Lives to Whole Persons," 172.

${ }^{56}$ Ibid., 174.
} 
of dependence (an affective aspect of faith development), and forms of community (social aspects of faith development)., ${ }^{, 57}$

Having laid developmental foundations of a stage model for spiritual formation in a 1992 article, professor Stephen Fortosis presents the theological groundwork for that theory which offers Simon Peter, the disciple/apostle, as a case study. He argues that because one biblical character of whom we know comparatively much is Peter, his "spiritual pilgrimage would appear invaluable as examined alongside the stage theory of spiritual development." 58 The stages he advances with biblical evidence are (1) from egocentrism to self-transcendence; (2) from little biblical knowledge to thorough knowledge; (3) from dualistic moral outlook to universalized outlook; (4) from conditional love to compassion for others; (5) from feeling orientation to unwavering faith; (6) from juxtaposed motives/attitudes to little public/private duplicity; (7) from theological instability to secure flexible theology; (8) from fluid convictions to internalized convictions; and (9) from idealized relationship with God to deep, consistent intimacy with God. ${ }^{59}$

Although Dallas Willard holds an earned doctorate in philosophy and is an ordained minister, he addresses the need for Christian psychology and developmental theories of spirituality authoritatively when he says,

The spiritual side of the human being, Christian and non-Christian alike, develops into the reality which it becomes, for good or ill.... We need to take a conscious, intentional hand in the developmental process. We need to understand what the formation of the human spirit is, and how it can best be done as Christ would have it

${ }^{57}$ Parks, Big Questions, Worthy Dreams, 70-133.

${ }^{58}$ Stephen Fortosis, "Theological Foundations for a Stage Model of Spiritual Formation," Religious Education 96, no.1 (Winter 2001): 49.

${ }^{59}$ Ibid., 50-56. 
done. This is an indispensable aspect of developing a psychology that is adequate to human life."

He continues,

A psychology that is Christian, in the sense of a comprehensive understanding of the facts of spiritual life and growth, should be a top priority for disciples of Jesus, particularly those who work in the various fields of psychology and who consider it an intellectual and practical discipline. No understanding of the human self can be theoretically or practically adequate if it does not deal with the spiritual life. ${ }^{61}$

Describing a developmental process of spiritual formation that is theoretically and practically adequate, Willard offers these insights.

At the core of the human being is will, spirit, and heart. This core is reshaped, opening out to the reshaping of the whole life, only by engagement. First, engagement is to act with Christ in his example and his commands: "If you love me, keep my commands," he said, "and I will ask the Father to send you another strengthener, the Spirit of truth" (John 14:15-17). The engagement must come first, followed by the helper insofar as obedience is concerned; as we try, fail; and learn we engage with the spiritual disciplines. We add whole-life training to trying. ${ }^{62}$

And in constructing a spirituality measure based on learning theory, $\mathrm{O}$. Jane

Thayer, professor emerita of religious education at the Seventh-day Adventist

Theological Seminary of Andrews University, contributes significantly to the research on spiritual development "by integrating theology and learning theory to build a conceptual

framework for an instrument to measure potential for spiritual growth."93

This study has created the concept of spiritual development modes that are defined as learning modes by which one engages with God and others through spiritual disciplines. ... The most important point of the theory is that holistic spiritual growth requires different kinds of learning obtained by active participation in a relationship with

\footnotetext{
${ }^{60}$ Dallas Willard, "Spiritual Formation in Christ: A Perspective on What It Is and How It Might Be Done," Journal or Psychology and Theology 28, no. 4 (2000): 254.

${ }^{61}$ Ibid., 256.

${ }^{62}$ Ibid., 257.

${ }^{63} \mathrm{O}$. Jane Thayer, "Constructing a Spirituality Measure Based on Learning Theory: The Christian Spiritual Participation Profile," Journal of Psychology \& Christianity 23, no. 3 (2004): 204.
} 
God and God's word, active participation in relationships with other people, and critical reflection on both relationships. ${ }^{64}$

\section{Contemporary Interpretations of Spiritual Formation}

Current expressions of Christian spiritual formation are now reviewed. First in the minds of many when considering this subject matter is Richard Foster, author of the classic, Celebration of Discipline: The Path to Spiritual Growth. Foster states that "all real formation work is 'heart work'." ${ }^{65}$ He continues, "Of primary significance is our vital union with God, our new creation in Christ, our immersion in the Holy Spirit. It is this life that purifies the heart; when the branch is truly united with the vine and receiving its life from the vine, spiritual fruit is a natural result." $\$ 66$

Dallas Willard, formulates spiritual formation for the Christian as "the Spiritdriven process of forming the inner world of the human self in such a way that it becomes like the inner being of Christ himself. ${ }^{67}$ But He also understands it as requiring human participation. He suggests that "while it is simultaneously a profound manifestation of God's gracious action through his Word and Spirit, it is also something we are responsible for before God and can set about achieving in a sensible, systematic

${ }^{64}$ Thayer, "Constructing a Spirituality Measure," 204.

${ }^{65}$ Richard Foster, "Spiritual Formation Agenda," Christianity Todoy 53, no. 1 (2009): 28.

${ }^{66}$ Ibid.

${ }^{67}$ Dallas Willard, Renovation of the Heart: Putting on the Character of Christ (Colorado Springs: NavPress, 2002), 22. 
manner." ${ }^{, 68}$ For Willard, "spiritual formation in Christ is oriented toward explicit obedience to Christ." ${ }^{\prime 69}$

In all of his writings, M. Robert Mulholland Jr., retired professor of New Testament theology and vice president for academic affairs at Asbury Theological Seminary, defines spiritual formation as "the process of being conformed to the image of Christ for the sake of others. ${ }^{70} \mathrm{He}$ explains that spiritual formation is not an option but is "the primal reality of human existence."71 Great emphasis is placed on the necessity to relinquish control to God to do the conforming which is "the great reversal of the negative spiritual formation of our culture." 72

Evan Howard, Director of the Spirituality Shoppe, an evangelical center for the study of Christian spirituality based in Montrose, Colorado, describes spiritual formation as involving "an intentional pursuit of God inspired by the leading of the Spirit, informed by the speaking of the Spirit and empowered by the work of the Spirit." ${ }^{.73}$ A loving critic of current trends in Christianity that tend toward a focus on feeling, he underscores the importance of realizing that "when we pursue the experience of God more than the God of the experience, we are not yet practicing Christian spiritual formation." ${ }^{74}$ He posits

${ }^{68}$ Willard, Renovation of the Heart, 25.

${ }^{69}$ Willard, "Spiritual Formation in Christ," 254.

${ }^{70}$ Mulholland, Shaped by the Word, 25-30.

${ }^{71}$ Ibid., 25.

${ }^{72}$ Ibid., 27.

${ }^{73}$ Evan Howard, "Three Temptations of Spiritual Formation," Christianity Today.46, no. 13 (2002): 49 .

${ }^{74}$ Ibid. 
that "while powerful experiences of God contribute significantly to our continuing formation, conformity with Christ comes ultimately only through a lifetime of obedience and the grace of the Spirit."75

James Wilhoit, Chair of Christian Formation and Ministry at Wheaton College, envisions spiritual formation in the biblical images of nurture, the journey, and death and resurrection. ${ }^{76}$ The first image is based on John 15 wherein Jesus describes His Father as the vinedresser, gardener or husbandman, Himself as the Vine, and His disciples as the Branches that must stay connected to Him in order to bear fruit. ${ }^{77}$ The second image borrows pictures of the Christian life as a race, a battle and struggle from Ephesians 6:12, 1 Corinthians 9:24-27, and Philippians 3:13-14. ${ }^{78}$ The final depiction of spiritual formation uses the imagery of death and life found in the passages such as John 3:1-8 and Romans 6:4. ${ }^{79}$

President of B\&H Publishing Group and former dean of the School of Leadership and Church Ministry at Southern Seminary, Brad J. Waggoner, having determined that spiritual formation can be observed and measured, identified twenty-one "functional characteristics of a disciple and then categorized them into seven domains of spiritual formation. ${ }^{.80}$ These biblical quotients of spiritual formation are labeled as domains of

${ }^{75}$ Howard, "Three Temptations of Spiritual Formation," 49.

${ }^{76}$ James C. Wilhoit, Spiritual Formation as If the Church Mattered (Grand Rapids, MI: Baker Books, 2008), 19.

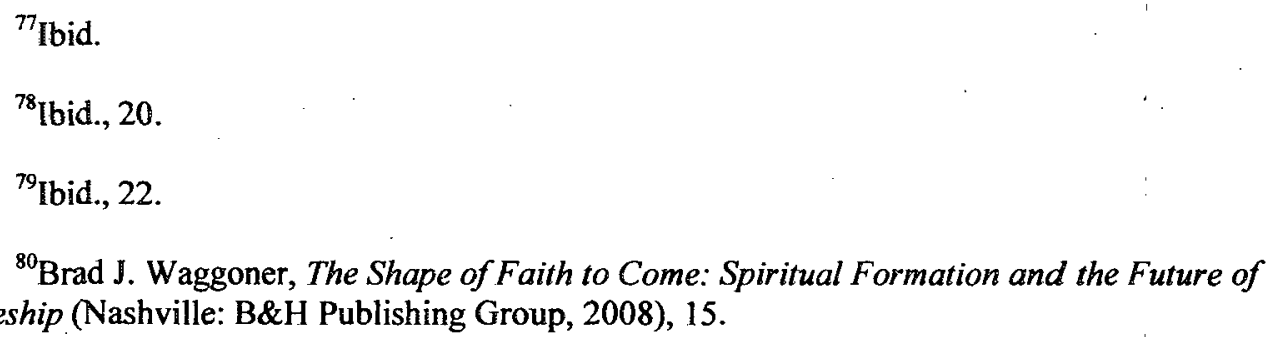


learning truth, obeying God and denying self, serving God and others, sharing Christ, exercising faith, seeking God, and building relationships. ${ }^{81}$ His contribution to this field also includes the personal or pastoral tool of an online spiritual formation assessment.

Kenneth Boa contends that, in seeking to ascertain the essence of the spiritual life, people make the same mistakes as did the blind men who felt different parts of an elephant, each assuming that what they felt completely defined the elephant. In his practical handbook, he presents twelve facets of spirituality that contribute to a holistic understanding of spiritual formation: relational, paradigm, disciplined, exchanged life, motivated, devotional, holistic, process, Spirit-filled, warfare, nurturing, and corporate. ${ }^{82}$

In her doctoral dissertation on the impact of intentional learning experiences for personal spiritual formation on seminary students, religious educator and administrator, Carol Tasker defines spiritual formation as follows: "The process of learning to live life as it was always meant to be-living in the presence of God, with God at the center of our lives, so that who we are with ourselves and with others and the world depends on who we are with God. ${ }^{83}$

African American theologian Cheryl J. Sanders characterizes a biblical vision of spiritual formation as "moral precept, ethical perspective, and liturgical practice that enables unrelenting struggle as free and responsible moral agents in a just society. ${ }^{84}$

${ }^{81}$ Waggoner, The Shape of Faith to Come, 16.

${ }^{82}$ Boa, Conformed to His Image, 21-23.

${ }^{83}$ Carol Tasker, Spiritual Formation: Unexpected Surprises for Pastors (Unpublished dissertation, Andrews University, 2001), 19.

${ }^{84}$ Cheryl J. Sanders, "African Americans, the Bible, and Spiritual Formation," in African Americans and the Bible, ed. Vincent L. Winbush (New York: Continuum, 2000), 600. 
And the "Scholar's Benediction" that appears at the end of the late James Washington's prayer anthology Conversations with God can be said to serve as a metaphor for African American spiritual formation. "Sweet Spirit, grant us the faith to resist our resistance to Thee! Bless those who pray to the One who is able to knead, shape, and bake us into a wholesome and holistic spiritual bread that can become a sacrament worthy for our children to partake. Amen!" ${ }^{85}$

The long and humbling journey of the Theological and Cultural Thinkers group (TACT) that resulted in the much-needed publication on The Kingdom Life is centered on "two categories of key elements pertaining to spiritual formation: process elements and theological elements. Process elements are those elements that have more to do with our practice of ongoing formation. The theological elements have to do with the major foundational biblical pillars of our being transformed into the image of Christ." ${ }^{86}$ Beginning with the seven process elements of spiritual formation, they are

Element 1: The gospel of the kingdom is the realm of God's active goodness in forming us in Christ as we follow Him. ${ }^{87}$.

Element 2: Spiritual formation is rooted in relationships with God and with one another. $^{88}$

Element 3: Spiritual formation into Christlikeness involves an intentional public, personal, and communal commitment to living as Jesus' disciples who are being

${ }^{85}$ James Melvin Washington, "Afterword: A Scholar's Benediction," in Conversations with God, ed. James Washington (New York: HarperCollins, 1994), 285-286.

${ }^{86}$ Alan Andrews, ed., The Kingdom Life: A Practical Theology of Discipleship and Spiritual Formation (Colorado Springs, CO: NavPress, 2010), 16.

${ }^{87}$ Ibid.

${ }^{88}$ Ibid., 17. 
transformed into His image in all aspects of our lives as we learn to obey His commands. ${ }^{89}$

Element 4: Spiritual formation is a lifelong pursuit of being conformed to the image of Christ from the inside out and not a matter of external activity alone..$^{90}$

Element 5: Spiritual formation is a continual process of transforming the whole person, including the healing of woundedness and rebellion, by the power of God, not to be confused with mere technique or program. ${ }^{91}$

Element 6: Spiritual formation occurs when God, in His grace, invades the destructiveness of suffering that results from the fall of man and uses the pain of suffering for His redemptive purposes in His people. ${ }^{92}$

Element 7: Spiritual formation in Christ is a process of growing in kingdom living and participating in God's mission. This begins with a personal reconciliation with God and results in an irrepressible manifestation of God's good news. Disciples of the kingdom labor in community for reconciliation with God and one another as a central priority of mission. They also pursue justice and compassion for all people and work to correct institutional sin inherent in human structures. ${ }^{93}$

Element 8: The theology of spiritual transformation emerges from the Trinitarian nature of God - relational, loving, gracious, mutually submissive, and unified in will. 94

Element 9: Spiritual formation takes place by the direct work of the Holy Spirit, regenerating and conforming us to the image of Jesus Christ as the Spirit indwells, fills, guides, gifts, and empowers people for life in the community of faith and in the world. $^{95}$

Element 10: Spiritual formation is based upon the Bible as God's reliable and authoritative revelation. The Bible, our primary source of truth, guides and informs

\footnotetext{
${ }^{89}$ Andrews, The Kingdom Life, 17.

${ }^{90}$ Ibid., 18.

${ }^{91}$ Ibid.

${ }^{92}$ Ibid., 19.

${ }^{93}$ Ibid., 19-20

${ }^{94}$ Ibid., 20

${ }^{95}$ Ibid., 21.
} 
the use of spiritual disciplines and models of spirituality as they have emerged worldwide and throughout time. ${ }^{96}$

Paula Fuller, vice president and director of multiethnic ministries for InterVarsity Christian Fellowship, states that "spiritual formation is not the end itself but is always pursued through and focused on the advancement of Christ's kingdom. We are God's chosen strategy for the world. ${ }^{97}$ She summarizes the necessity of participating in God's mission as integral to spiritual formation in the following statements;

Far too often, many of us shrink back from mission as a critical part of our spiritual formation, but it is precisely in those moments that God reshapes our hearts, minds and inner beings. As we experience God at work in people's lives and become conduits for His love and power, the gospel of Jesus penetrates our hearts and the places where we are not aligned with Him. As the good news of the gospel flows into the world, it also flows through us, and we are changed from the inside out. ${ }^{98}$

In an interview with Chaplain Joseph Modica for Christianity Today, Scot McKnight answers inquiries about his book, The Jesus Creed: Loving God, Loving Others, which he claims to be the end of spiritual formation. ${ }^{99}$ He states that the factors in the spiritual formation of Jesus were His parents and the sacred rhythms of Israel which included the synagogue Shabbat service. ${ }^{100} \mathrm{He}$ also posits that, like any Jew of during the first century, it is likely' Jesus would have recited the Shema ("Hear O Israel: The LORD our God is one LORD. Love the LORD your God" (Deut 6:4-5) and "Love

${ }^{9}$ Andrews, The Kingdom Life, 21.

${ }^{97}$ Paula Fuller, "Participating in God's Mission," in The Kingdom Life: A Practical Theology of Discipleship and Spiritual Formation," ed. Alan Andrews (Colorado Springs, CO: NavPress, 2010), 193.

${ }^{98}$ Ibid., 218.

99 Joseph B. Modica, "Jesus' Guide to Spiritual Formation," Christianity Today 49, no. 4 (2005): 105.

${ }^{100}$ Ibid. 
your neighbor as yourself" (Lev 19:18) twice a day ${ }^{101}$-the basis of the Great Commandment.

In the next portion of this chapter we will examine recent studies on religious and theological education in public and private colleges and universities in the United States.

\section{Religious/Theological Education in Colleges/Universities in the United States}

In many instances, the value an educational institution places on the spiritual life of the academic community and the spiritual development of students, in particular, is evidenced by its aim and statement of mission. But often these proclamations reflect more rhetoric than reality. Every educational institution must create and live out of a holistic philosophy that shapes and informs curriculum as well as every other aspect of campus life which includes its relationship to the community.

\section{Philosophy}

The word philosophy can be defined as "a theory underlying or regarding a sphere of activity or thought." "102 It encompasses "the beliefs, concepts and attitudes of an individual or a group." $"$ The significance of philosophy is that it creates and provides the essential undergirding and governing guidelines for considerations relevant to the endeavors that the philosophy addresses.

V. James Mannoia Jr., Senior Fellow for the International Development for the

\footnotetext{
${ }^{101}$ Modica, "Jesus' Guide to Spiritual Formation," 105.

${ }^{102}$ Webster's Seventh New Collegiate Dictionary (1971 ed.), s.v. "Philosophy."

${ }^{103}$ Ioid.
} 
Council for Christian College \& Universities and former president of Greenville College, contends that Christian liberal arts institutions have a distinctive mission to go a step beyond both secular universities and other kinds of religious institutions of higher education. He argues for two essential characteristics that arise from the Christian's call to become like Christ and to serve others, respectively. ${ }^{104}$

The first is my belief that Christian liberal arts colleges should produce graduates who are critically committed. That is to say, they are persons with a rare combination of passion and humility toward what they believe. They are strongly committed to these beliefs in spite of careful and ongoing critical reflection on them. To become a person of such character and virtue is an essential intrinsic value of Christian liberal arts education.

The second is my belief that Christian liberal arts colleges should produce graduates who are integrative, that is, persons who are able to address themselves to real human problems. To do this competently, willingly and self-sacrificially wherever they may live and work is an essential instrumental value of Christian liberal education. ${ }^{105}$

Thus, Mannoia 's paradigm makes professor/author Leroy Ford's case for the educational philosophy of Christian liberal arts colleges to be based on "a set of equipping outcomes which all students need to master in order to function effectively in Christian ministry."106 Mannoia and Ford would agree that these outcomes reflect holistic education, integration of faith and learning as well as service learning.

In September 1998, a national event, dubbed Education as Transformation, was held at Wellesley College to focus on the issues of religious pluralism and spirituality in

\footnotetext{
${ }^{104}$ V. James Mannoia Jr., Christian Liberal Arts: An Education That Goes Beyond (Lanham, MD: Rowman \& Littlefield Publishers, 2000), 7.

${ }^{105}$ Ibid.

${ }^{106}$ LeRoy Ford, A Curriculum Design Manual for Theological Education: A Learning Outcomes Focus (Eugene, OR: Wipf and Stock Publishers, 1991), xv-xvi, quoted in The Oakwood University Department of Religion and Theology Handbook, 2008-2009 (Huntsville, AL: Oakwood University, 2008), 18.
} 
higher education. It "drew over 800 participants from more than 250 institutions, including 28 college and university presidents, 210 faculty, 170 administrators, 205 students, 112 religious life professionals and 82 alumni/ae, trustees, and representatives of related organizations." 107

Since then there has been an emergence of activities on many campuses and by many groups such, that in 2003, diverse organizations (the Fetzer Institute, the Initiative for Authenticity and Spirituality in Higher Education, and the Community for Integrative Learning and Action) agreed to work together to engage in the groundwork for the development of an overarching philosophy of education as transformation. ${ }^{108}$

Education as Transformation has become an international organization that works with colleges, universities, K-12 schools and related institutions exploring: (1) the impact of religious diversity on education and strategies for addressing this diversity; and (2) the role of spirituality in educational institutions, and particularly its relationship to teaching and learning pedagogy; the cultivation of values; moral and ethical development; and the fostering of global learning communities and responsible global citizens. ${ }^{109}$

Promoting holistic student development in higher education requires consistent intentionality. Professors Larry Braskamp, Lois Trautvetter, and Kelly Ward, authors of Putting Students First, assert that "it takes a whole campus to whole persons to develop whole students" and conveys a philosophy of creating a campus that intentionally guides students in finding meaning and purpose. ${ }^{110}$

\footnotetext{
${ }^{107}$ Peter Laurence, "Education as Transformation: History of a Movement," Spirituality in Higher Education Newsletter 1, no. 1 (April 2004): 2.

${ }^{108}$ Ibid., 3.

${ }^{109}$ Education as Transformation, www.wellesley.edu/RelLife/transformation/index.html (accessed January 10, 2011).

${ }^{110}$ Larry Braskamp, Lois Calian Trautvetter, and Kelly Ward, "Putting Students First: Promoting Lives of Meaning and Purpose," About Campus 13, no. 1 (March-April 2008): 31.
} 
An article about their study of ten church-related colleges, published several years earlier, sought to better understand the ways in which faculty are committed to the cognitive and psychosocial (including spiritual and moral) development of students both in and out of the classroom. These colleges proved to be forerunners.

Questioning the widely held principle that students might best prepare themselves for the life journey, particularly in the world of work, by being enrolled in a professional career curriculum, these church colleges regard meaning and purpose not as private matters, divorced from the intellectual and academic pursuits, but rather as an individual investment towards 'making a difference' in this world. These colleges were concerned about linking career and calling so that graduates have opportunities to cultivate skills in critical self-reflection as well as a new lexicon for experiencing their chosen vocation. ${ }^{111}$

The research team of Braskamp, Trautvetter, and Ward emphasizes the necessity of obtaining the commitment between faculty and student affairs administrators to create a framework of collaborative environments in the contexts of culture, curriculum, co-curriculum, and community. ${ }^{112}$

David Hindman contends that one crucial, yet oftentimes neglected, component in helping students to develop their spirituality is "an explicit, overt public commitment from the institution itself to assist students in acquiring a particular set of values and attitudes about themselves and the larger community."113 He argues that "as with the rest of education, the spiritual development of students requires intentionality and consistency

\footnotetext{
${ }^{11}$ Larry Braskamp, Lois Caian Trautvetter, and Kelly Ward, "How College Fosters Faith Development in Students," Spirituality in Higher Education Newsletter 2, no. 3 (July 2005): 6.

${ }^{112}$ Ibid., 27.

${ }^{113}$ Hindman, "From Splintered Lives to Whole Persons," 175.
} 
of aim." 114 Further he claims that "the spiritual development of students can be enhanced as they live in a community committed to consistency of moral purpose and action."115

Hindman insists that "the spiritual development of students is enhanced when they are provided models and images of the spirited life." entire academic environment, he declares that "this requires faculty and staff to be on their own spiritual journeys."117

And recognizing the many responsibilities that challenge those most able to model the spirited life, Hindman recommends that "faculty and staff need opportunities not only to deal with institutional issues such as budget and staffing, but to be together to share friendship, stories, intimacy, values and commitments, joys and sorrows."118

Talbert O. Shaw, former president of Shaw University in Raleigh, North Carolina, asserts that Shaw University (the similarity of the president's and the university's names is purely coincidental) is "known for character education." 119 He explains.

Its curriculum encompasses the arts, social and natural sciences, humanities, business, computer science, education, religious studies, and ethics. Its moral thrust requires all students to earn credits in ethics and values; thus ... all students understand the ethical dimensions of their major fields of study. Shaw's curriculum aims at quantitative and qualitative education with a focus on holistic development of each student. It is an educational program predicated on the philosophy of an inspired

\footnotetext{
${ }^{114}$ Hindman, "From Splintered Lives to Whole Persons," 175.

${ }^{115}$ Ibid., 176.

${ }^{116}$ Ibid., 178.

${ }^{117}$ Ibid., 179.

${ }^{118}$ Ibid., 180.

${ }^{119}$ Talbert $\mathrm{O}$. Shaw, “Character Education: The Raison d'être of Historically Black Colleges and Universities," in How Black Colleges Empower Black Students: Lessons for Higher Education, ed. Frank W. Hale Jr. (Sterling, VA: Stylus Publishing, 2006), 95.
} 
writer who declares that true education is the "right development of the physical, intellectual, and moral powers" of students. ${ }^{120}$

Further he states that Shaw University "is in consonance with other HBCUs' [historically black colleges and universities] requiring students to engage in servicelearning assignments"121 as a prerequisite for graduation.

Mervyn Warren, former Provost and Senior Vice President at Oakwood University, acknowledges the veracity of Talbert Shaw's implications regarding the unique contribution of historically black colleges and universities in providing character education in his 2006 article that visions values in higher education. He states, "Among the approximately 4,009 colleges and universities in America, including some eighty-four historically Black institutions of higher learning, are a number of schools that transcend the silent treatment by placing values on the front burner along with academic, per se, thereby providing context and purpose for a moral philosophy of higher education."122

Warren provides a working definition of values as "standards, directions, and parameters of conduct for the best common good of the human race motivated by love and service." $" 123$

Arguing that "if character education is to be effective, it must be responsive to the

${ }^{120}$ Shaw, "Character Education, 97.

${ }^{121}$ lbid.

${ }^{122}$ Mervyn A. Warren, "Old Wine in New Bottles: Visioning Values in Higher Education," in How Black Colleges Empower Black Students, ed. Frank W. Hale, Jr. (Sterling, VA: Stylus Publishing, 2006), 201.

${ }^{123}$ Ibid., 202. 
values and narratives of particular culture groups, offer a counter-narrative approach to formulating educational philosophy, believing that "by grounding character education in the history, literature and cultural and religious values of African Americans, the integration of psychological, spiritual and academic development of the next generation of African-American youth is more likely.",125

Director of College Ministries at Edgewood College (a small, Catholic, liberal arts school) in Madison, Wisconsin, Mary Klink offers helpful suggestions on the development of institutional "buy-in" relative to the spiritual development of students. Although her focus is not that of an educational philosophy per se, "Edgewood created a campus Vision and Values statement for Encouraging Student Spiritual Development and structured intentional training and development sessions" ${ }^{\prime 26}$ for staff and administration that serve as a model for cultivating an institutional shared vision out of which educational philosophy is best actualized.

Larry J. McKinney, Board Chair Emeritus for the International Council for Evangelical Theological Education, in a 2005 article published in the Evangelical Review of Theology, examines five theological issues that are prominent in debates about Christian education and theological education: knowledge of God; centrality of written revelation; role of the Holy Spirit; nature of humankind; and goal of Christian

\footnotetext{
${ }^{124}$ Louis B. Gallien and LaTrelle Jackson, "Character Development from African-American Perspectives: Toward a Counternarrative Approach," Journal of Education \& Christian Belief 10, no. 2, (2006): 129.

${ }^{125}$ Ibid.

${ }^{126}$ Mary Klink, "Creating Shared Vision for Promoting Students' Spiritual Development: An Intervention Model from Edgewood College," Spirituality in Higher Education Newsletter 5, no. 3 (2007): 1.
} 
maturity. ${ }^{127}$ Building on the argument that pedagogy and theology are equally important in defining the purpose and nature of theological education, he concludes,

When theological educators understand the importance of growing in relationship with God, the true purpose of the Bible, the role of the Holy Spirit in teaching, the implications of human nature, and the essence of spiritual maturity, they will be far better equipped to shape the lives of their students. Without this understanding, theological education is reduced to programs and activities that have no higher calling than to make students feel content about their academic and professional lives. ${ }^{128}$

\section{Curriculum}

"The courses offered by an educational institution" 129 are commonly called the curriculum which is informed and shaped by the educational philosophy of an institution. Typically, a curriculum is organized round core concepts with integrating themes. Among models of curriculum designs are those that embrace learning outcomes or terminal objectives. ${ }^{130}$

V. James Mannoia differentiates between formal curriculum (including the course requirements and the dominant modes of teaching) and informal curriculum (noncredit granting aspects of the collegiate program and environment), stating that "both are indispensable contributions to students' lives and are the major tools educational institutions use to accomplish their mission and implement their vision." ${ }^{" 131}$ But of

\footnotetext{
${ }^{127}$ Larry J. McKinney, "A Theology of Theological Education: Pedagogical Implications," Evangelical Review of Theology 29, no. 3 (2005): 219-227.

${ }^{128}$ Ibid., 227.

${ }^{129}$ Webster's Seventh Collegiate Dictionary (1971 ed.), s.v. "Curriculum."

${ }^{130}$ Ford, A Curriculum Design Manual, xv-xvi.

${ }^{131}$ Mannoia, Christian Liberal Arts, 7.
} 
greater value is the argument he makes for curriculum to be both developmental and integrative.

According to Mannoia, specific requirements must be met if a formal curriculum is to be developmental. First, colleges need to have better information about the students they are admitting. Second, attention should be given to the sequence in which general education courses are taught. Third, attention should be paid to the range of developmental positions found in any given classroom. Fourth, the formal curriculum should have implications for teaching (i.e., functioning simultaneously as the creator of both cognitive dissonance and personal community). ${ }^{132}$ Similarly, he advances the tenets of an integrative formal curriculum as involving "integration of multiple disciplines, of theory and practice and of learning with faith."133

In the spirit of Mannoia, as a first step toward the development of a new model of Christian higher education that will intentionally facilitate spiritual maturation; Ronald Welch and Kimberlee Mellberg assessed spiritual maturation processes of internalization and questing to determine their relationship to year in school and certain religious behaviors. ${ }^{134}$ Their study also included gender-specific findings that are addressed in their counsel to educators and administrators of faith-based colleges and universities.

We recommend that Christian universities approach males and females differently when encouraging spiritual growth, while also providing different types of spiritual maturation programs for students depending on their year in school. First-year students are bombarded with changes, including adapting to increased responsibility and separation from their home church and previous spiritual leaders. In contrast,

\footnotetext{
${ }^{132}$ Mannoia, Christian Liberal Arts, 137-140.

${ }^{133}$ Ibid. 142.

${ }^{134}$ Ronald D. Welch and Kimberlee Mellberg, "Spiritual Maturation and Religious Behaviors in Christian University Students," Christian Higher Education 7 (2008): 142.
} 
senior students are facing the challenges of the work world, marriage and family possibilities, and financial responsibility. A Christian university could integrate this knowledge into a spiritual maturation program by gradually introducing more cognitive challenges and questing into classroom experiences, rather than overwhelming students with theological questions in their first year. ${ }^{135}$

To understand the role that faculty play in the spiritual development of students, the research team of Astin, Astin and Lindholm surveyed faculty members at the same institutions from which was collected longitudinal student data and found the potential for considerable curriculum challenges.

When we pose to faculty the question of whether college should attend to facilitating student's spiritual development, we find substantial differences in responses based on. their academic field. The highest levels of faculty agreement with the notion that colleges should be involved in facilitating students' spiritual development are found in the health sciences, and the lowest levels are in the biological sciences, social sciences, physical sciences, and agriculture/forestry. ${ }^{136}$

In the article "Classroom Formation \& Spiritual Awareness Pedagogy Based on Bonhoeffer's Life Together," Neil Holm considers a variety of classroom processes that enable students to embody the disciplines of communal life as Christians who take their call to discipleship seriously.

Steven Frye examines how religious instruction can occur in higher education settings and offers recommendations "for helping adult learners navigate the treacherous waters of challenge to their beliefs." 137

Frye offers the four challenges for the teaching/learning encounter in religious education settings:

${ }^{135}$ Welch and Mellberg, "Spiritual Maturation and Religious Behaviors," 159.

${ }^{136}$ Astin, Astin, and Lindholm, Cultivating the Spirit, 41.

${ }^{137}$ Steven Frye, "Religious Education and Faith Challenges in the College Classroom," Adult Learning 18, nos. 1/2 (2007): 12. 
1. Appreciate the reality that students are bring a level of expectation to the classroom that can impact how questions and challenges will affect them.

2. Be careful not to assume we know what will challenge learners.

3. Create a safe environment for questions.

4. Model asking questions and openness to dissonant beliefs. ${ }^{138}$

He concludes that "classrooms that deal with issues of the learners' faith have tremendous potential for significant learning experiences, yet they also are rife with potential struggles." ${ }^{\prime 139}$ In his doctoral dissertation he explored the components of a supportive and open environment for adult learning and development and determined that the five domains of the classroom that affect students' feelings of safety are (1) self, (2) professor, (3) class structure, (4) materials and subject, and (5) peers. ${ }^{140}$

Derise E. Tolliver and Elizabeth Tisdell discuss the challenges of fostering spirituality in the higher education classroom and its relationship to the practice of transformative learning in their chapter of the book Teaching for Change. Although their projected audience was probably faculty of public institutions of higher learning, there is much that is valuable for the faculty of Christian colleges and universities as well. They present a "model of spiritually grounded and culturally responsive pedagogy for transformative learning"141 applicable to practice which includes the following components:

- An emphasis on authenticity of teachers and students

\footnotetext{
${ }^{138}$ Frye, "Religious Education and Faith Challenges, 13-14.

${ }^{139}$ Ibid., 14.
}

${ }^{140}$ Steven Blake Frye, "How Adult Students Experience Having Their Beliefs Challenged in an Undergraduate Religion Class: A Phenomenological Analysis" (Unpublished doctoral dissertation, University of Tennessee, Knoxville, 2007), 33,

${ }^{141}$ Derise E. Tolliver and Elizabeth J. Tisdell, "Engaging Spirituality in the Transformative Higher Education Classroom," New Directions for Adults and Continuing Education 109 (2006): 40. 
- An environment that fosters the exploration of multiple forms of knowledge production including: the cognitive (through readings and discussion of ideas), the affective and relational (through connection with other people and of ideas to life experience), the symbolic, spiritual, and imaginative domain (through drawing on symbol and metaphor in the use of art form such as poetry, art, music, drama and ritual)

- Readings that reflect the cultures of the members of the class and the larger community

- Exploration of individual and communal dimensions of cultural and other dimensions of identity

- Collaborative work that envisions and presents manifestations of multiple dimensions of learning and strategies for change

- Celebration of learning and provision for closure to the course

- Recognition of the limitations of the higher education classroom and that transformation is an ongoing process that takes time. ${ }^{142}$

In 2005 the Spirituality Project team of the Higher Education Research Institute invited the readership of the Spirituality in Higher Education Newsletter to submit syllabi used within higher education classrooms that they considered to be 'distinctly spiritual' in nature and from the submissions discovered three major categories that reflected the uses of spirituality and spiritual practice in the classroom:

(1) Spirituality as a means of enhancing disciplinary or field knowledge in which spirituality operates as a complement to existing content within a field or discipline; (2) Spirituality as a new paradigmatic lens for everyday life which highlights the varied ways in which spirituality is manifest within our everyday existence; and (3) Spirituality as pedagogy which is the application of spirituality as a pedagogical technique such as the use of reflection, meditation, journaling as a way to enhance the dimensional quality of in-class proceedings. ${ }^{143}$

"Teaching and Learning in the Service of Transformation" by Charles Foster acknowledges the work of Eliot Eisner who asserts that in addition to an explicit curriculum - 'the expectations of the school's sponsors and leaders are articulated in

\footnotetext{
${ }^{142}$ Tolliver and Tisdell, "Engaging Spirituality," 40-41.

${ }^{143}$ HERI Spirituality Project Team, "Spirituality \& the Higher Education Curriculum: The HERI Syllabi Project," Spirituality in Higher Education Newsletter 2, no. 2 (April 2005): 3.
} 
missions and policy statements, courses of study, course goals and assignments, methods of instruction and the standard teachers use in assessing student work." ${ }^{144}$ Further he states that there is an implicit curriculum "that often exists outside the consciousness of teachers and students." 145

[T]he implicit curriculum] includes the structures and relationships, values and rituals that establish the norms in the pedagogical culture of a school, program, department or class. It includes connecting beliefs about the relationship of disciplinary traditions of knowing and knowing how with the values and commitments embedded in the mission and traditions of the school. ${ }^{146}$

Like Foster affirms the reality of formal and informal curricula in educational institutions. He declares that curriculum aiming to promote spiritual development must be holistic and integrative, recognizing that learning in one area of the curriculum has relevance to other curriculum areas, ${ }^{147}$ and contending that "the spiritual is intended to pervade the whole educational process" ${ }^{\prime 48}$ per the Education Act of 1944.

\section{Religious/Theological Education in SDA Colleges/Universities in the United States}

The rationale and conceptual framework for religious/theological education in Seventh-day Adventist denominational institutions of higher learning in the United States are often prompted by an assessment of many realities. They can also be dictated by the mission, beliefs, and practices of their affiliates or mandated by larger governing entities. (2007): 41 .

${ }^{144}$ Charles R. Foster, "Teaching and Learning in the Service of Transformation," Change 39, no. 3

$$
{ }^{145} \text { Ibid. }
$$

${ }^{146}$ Ibid.

${ }^{147}$ Christopher Meehan, "Promoting Spiritual Development in the Curriculum," Pastoral Care in Education 20, no. 1 (2002): 22.

${ }^{148}$ Ibid. 
And both the needs of the constituents (whether in churches, classrooms, hospitals, penal institutions or on college and university campuses) to be served by the graduates of these Seventh-day Adventist institutions of higher learning as well as the needs of the graduates themselves must be of prime importance as well in shaping of philosophy.

\section{Philosophy}

At the September 19, 2001, meeting of the International Board of Ministerial and Theological Education, which I attended as a member, it was voted to approve the Handbook of Seventh-day Ministerial and Theological Education, including the appendices among which is "A Statement of Seventh-day Adventist Educational Philosophy - Version 7.8". Humberto Rasi, former executive director of the Institute for Christian Teaching and editor-in chief of College and University Dialogue, explains that the statement was precipitated by the dramatic expansion experienced by Adventist education and that more than 250 scholars, researchers, teachers, and administrators from many nations convened on the campus of Andrews University during the month of April in 2001 to revisit efforts made in the 1950s to provide "foundational guidance for the formation of teachers, the establishment of schools, colleges and universities, and the nurture of students." 149

The philosophy is Christ-centered and reflects distinctive characteristics of Adventism that are derived from the Bible and the writings of Ellen G. White. ${ }^{150}$

\footnotetext{
${ }^{149}$ Humberto M. Rasi, Paul Brantley, George Akers, John M. Fowler, George Knight, John Matthews, and Jane Thayer, "Toward a Statement of Educational Philosophy," special edition, Journal of Research on Christian Education 10 (2001): 173.

${ }^{150}$ Thayer, "A Statement of Seventh-day Adventist Educational Philosophy," 348.
} 
Adventist education imparts more than academic knowledge. It fosters a balanced development of the whole person-spiritually, intellectually, physically and socially. Its time dimensions span eternity. It seeks to develop a life of faith in God and respect for the dignity of all human beings; to build character akin to that of the Creator; to nurture thinkers rather than mere reflectors of others' thoughts; to promote loving service rather than selfish ambition; to ensure maximum development of each potential; and to embrace all that is true, good, and beautiful. ${ }^{151}$

Included in this statement are the aim, mission, and agencies of Adventist education (home; local church; school, college, and university; and world church). Its redemptive aim is to restore human beings into the image of their Maker. ${ }^{152}$ "The mission of Adventist education is to prepare students for a useful and joy-filled life, fostering friendship with God, whole-person development, Bible-based values, and selfless service in accordance with Seventh-day Adventist mission to the world."153

An additional document attached to the foregoing statement is entitled "The Role of Seventh-day Adventist Schools, Colleges and Universities" which outlines key components as well as responsibilities and outcomes.

Niels-Erik Andreason, president of Andrews University, the flagship educational Seventh-day Adventist institution, echoes the call for a unique, distinctive Christian perspective in Christian colleges and universities in a 2005 article that was adapted from his Fall Semester Convocation address that year. He advances the position that what defines Andrews University (and, by inference, all Seventh-day Adventist educational institutions) is that "Seventh-day Adventist Christians wait for Christ to come, and an

\footnotetext{
${ }^{151}$ Thayer, et al., "A Statement of Seventh-day Adventist Educational Philosophy," 348.

${ }^{152}$ Ibid.

${ }^{153}$ Ibid., 349.
} 
Adventist university instructs its faculty, staff and students to live expectantly."154

He asserts that "it is all in our name, Adventist. A Latin word which means to come. Not we coming to Christ, like the evangelicals might say, but Christ, yes God Himself, coming to us."155 Further, he adds that the other part of our name, Seventh-day, informs our waiting expectantly as well for "the Sabbath comes to us when it comes, and with it God comes too, and there is precious little we can do to advance or delay it. We must wait for it, by living expectantly. ${ }^{156}$

Andreason explains "waiting expectantly" as a special way of waiting in which we wait in an attitude of responsibility toward our brothers and sisters in this world, for they too are God's children and He is coming to them too, and we like them to wait with us. We wait patiently in the present world and we wait for the world to come. Therefore we care for the world while we wait, for it is God's handy work. We do that by protecting its clean air, pure water, green trees and other material resources.

We wait for a new and better world, so we wait with a certain detachment toward material things, our possessions. They do not last, so we will not become too attached to them. Therefore, whether we study social sciences, natural sciences, religion, engineering or economics, or another field, our Adventist faith wants a place at the table of our teaching and learning. Our faith wants to teach us how to wait for God. And all courses of study in this Christian university contribute to this faith of ours, as we learn to live expectantly . . always ready to meet Him. ${ }^{157}$

A contributor to the development of the statement of Seventh-day Adventist educational philosophy and former director of the Department of Education for the General Conference of Seventh-day Adventist, Humberto Rasi addresses the challenge of "the relativism that characterizes much of postmodern thought [and] deprives knowledge

\footnotetext{
${ }^{154}$ Niels-Erik Andreason, "Is God Coming to Campus Too? Thoughts on the Distinctive Features of Adventist Higher Education," Journal of Research on Christian Education 14, no. 2 (2005): 124.

${ }^{155}$ Ibid.

${ }^{156}$ Ibid., 124.

${ }^{157}$ Ibid., 125-126.
} 
and values of a reliable foundation." 158 He urges Adventist educators "to be ready to be both committed and compassionate as we seek to provide biblically anchored, wholistic Christian education to our students in a postmodern cultural context." $" 159$

Written during his tenure as World Director of Education for the Seventh-day Adventist Church, C. Garland Dulan asks, in an editorial of a denominational publication, "Is Adventist Education Worth It?" Believing that education is a crucial process through which preparation for God's kingdom occurs, Dulan boldly declares that "should this vision of mission be lost, there would be no reason for our schools to exist." 160 In that essay, he articulates the formulation of Seventh-day Adventist Christian educational philosophy in the characteristics of what he refers to as Redemption-Oriented Schools of Excellence (ROSE).

1. They are very clear and unapologetic about their mission.

2. Their goals and objectives stimulate attitudes and processes of operation that convey academic and behavioral expectations which are consistent with their mission.

3. Their personnel (faculty and staff) exemplify institutional ideals and are selected with this in mind.

4. They provide their students with opportunities for service and outreach, and inspire them to make a contribution to society and to the church.

5. Their programs are strong in quality and content.

6. Parents, constituents, and church leaders perceive the education as excellent and well worth the cost, and provide solid financial support.

7. The school, the local community and the church constituency collaborate for success.

8. The facilities reflect what is expected of a school with high standards. ${ }^{161}$

\footnotetext{
${ }^{158}$ Humberto Rasi, "Adventist Education and the Challenge of Postmodernism," The Journal of Adventist Education 71, no. 2 (2008): 16.

${ }^{159}$ Ibid.

${ }^{160} \mathrm{C}$. Garland Dulan, "Is Adventist Education Worth It?" The Journal of Adventist Education 66, no. 3 (2004): 3 .

$$
{ }^{16 !} \text { Ibid., 3, } 46 .
$$
}


Clearly the editorial question is not rhetorical within the context of redemption.

Frank W. Hale Jr., the only president of Oakwood College (now University) who was not a member of the clergy, shares his insights on Seventh-day Adventist Christian education from the perspective of an alumnus of, as well as faculty and administrator, at Oakwood in his autobiography, Angels Watching Over Me. He notes that upon completing the requirements for the doctoral degree at The Ohio State University, he returned to the school "compelled to counterbalance any suggestion that there was at Oakwood an atmosphere which was anti-intellectual." 162 He contends that "it was always assumed by some people, Adventist and non-Adventist, that a heavy emphasis on Christian education would somehow diminish the academic growth of any educational institution."163

In April 1966, while teaching at Central State University in Wilberforce, Ohio, Hale submitted an article entitled "The Way Ahead" to the Oakwood Alumnarian at the request of the editorial staff. In a sort of serendipitous projection, he chartered a course to follow in the days ahead when he was elected to serve as president of Oakwood in June 1966 when he wrote

The role of Oakwood College in maintaining educational and religious balance under the adverse conditions of pioneer life, and in nurturing its growth in recent decades is a story of the triumph of a virile religious faith. It is this spirit that must be preserved if its "moral and spiritual" character is not to be attenuated by a variety of compromises that would render opaque its objectives. ${ }^{164}$

Newly-elected president of Oakwood University, Leslie N. Pollard, articulates his vision for implementing the educational philosophy of his alma mater in a recent edition

\footnotetext{
${ }^{162}$ Frank W. Hale Jr., Angels Watching Over Me: The Autobiography of Dr. Frank W. Hale, Jr. (Nashville, TN: James C. Winston Publishing Company, 1996), 113.

${ }^{163}$ Ibid.

${ }^{164}$ Ibid., 217.
} 
of the Oakwood University Magazine. Envisioning the institution in the year 2020, he sets forth his dream for how the school will come to be considered a premier university in Huntsville, Alabama and the Seventh-day Adventist church. He shares,

This vision leads us to serve our students with renewed purpose and passion.

Oakwood graduates of the 21 st century receive a quality education that prepares them for top-tier professional or graduate schools. The spiritual atmosphere and culture at Oakwood engages every student in mission to communities. Intentionality around the spiritual formation of OU students is evident in every area of the campus. Every class within the curriculum reflects the integration of faith and learning. ${ }^{165}$

This emphasis on the integration of faith and learning is evident in even a cursory survey of the mission statements, aims and mottos of Seventh-day Adventist colleges and universities in the United States which reveals an intentionality to reflect and embody the elements of the denominational educational philosophy. Examples include "Seek Knowledge, Affirm Faith, Change the World" (Andrews University); "Seek Truth, Know God, Serve Others (La Sierra University); "Excellence in thought, Generosity in service, Beauty in expression, Faith in God" (Walla Walla College); and "Education, Excellence, Eternity" (Oakwood University).

\section{Curriculum}

In the perspectives that follow the centrality of Christ and biblical principles are clearly evident in the shaping of curriculum at American Seventh-day Adventist Tertiary Institutions.

C. Garland Dulan, who following his retirement as Director of Education for the General Conference of Seventh-day Adventists, agreed to serve as Vice President for Academic Affairs at Oakwood University where he continued to promote the Bible as the

${ }^{165}$ Leslie N. Pollard, “Vision 20/20," Oakwood University Magazine, Spring 2011, 31. 
basis for the best possible education, depicts not only an integration of faith and learning

but also as an integration of faith and practice. This is a critical component of Dulan's

vision for the philosophy of Seventh-day Adventist religious/theological education.

When biblical principles underlie the essential ingredient of the curriculum, the result is a unified rather than fragmented understanding of our world. When biblical principles shape the context and instructional attributes of schools, this provides a solid basis for promoting students' growth in critical thinking, social interaction, spiritual insight, and knowledge about a healthy lifestyle, as well as the principles of psychological and physical well-being. In other words, scriptural principles become the lens through which other knowledge is interpreted and evaluated. ${ }^{166}$

Dulan clearly echoes the position of Ellen White. In her Counsels to Parents and

Teachers Regarding Education, she provided timeless advice in this regard.

I am instructed that we are to carry the minds of our students higher than is now thought to be possible. Heart and mind are to be trained to preserve their purity by receiving daily supplies from the fountain of eternal truth. The education gained from a study of God's word will enlarge the narrow confines of human scholarship, and present before the mind a far deeper knowledge to be obtained through a vital connection with God. It will bring every student who is a doer of the word into a broader field of thought, and secure to him a wealth of learning that is imperishable. $^{167}$

Always believing that the pen is mightier than the sword, Frank W. Hale Jr. continued writing as the chief executive officer of the college and throughout his life. In December 1966, early in his administration, he penned an article "From the Desk of the President" for the Spreading Oak, the school newspaper, to underscore the importance of values.

Since our college is what we are, the phrase, "set of values," looms as an important factor in establishing what we are. A person's set of values reflects his character and personality by revealing the things he considers important. A student who is motivated by a philosophy of Christian education can ill afford to meet the situations

${ }^{166}$ Dulan, "Is Adventist Education Worth It?" 3.

${ }^{167}$ Ellen G. White, Counsels to Parents and Teachers Regarding Education (Mountain View, CA: Pacific Press, 1913), 13. 
of life by "doing what comes naturally." His performance is determined by a higher order, by a Christian set of values and by ethical guidelines.

To assist the student to develop a highly refined system of values, the College has set lofty objectives in three areas - religious conviction (religion is the core of our curricula), environment (religious services - chapel, dormitory worship services, vespers, Sabbath services, Weeks of Prayer, etc.), and experience (Christian and denominational standards - foods, dress, music, recreation and social conduct). ${ }^{168}$

After describing the students who matriculate at Oakwood as coming "on scholarships and cash, financial aid, loans, and prayer ${ }^{\prime 169}$ (italics supplied) in their chapter entitled "Pathways to Success: Recruitment and Retention Methods at Oakwood College," former president and first lady of Oakwood, Delbert and Susan Baker, unpack the significance and relevance of the institution's motto as follows:

Education refers to the preparation and training students receive so that they can enter a career, job, or graduate or professional school with the academic skills necessary to be a success. Excellence is an attitude and expectation that students will excel in their academic endeavors, and that the college will provide a solid foundation for the development of mental, physical, social, and spiritual skills. Eternity highlights the importance placed on values and spiritual development. ${ }^{170}$

In the next section of this chapter, we will examine the extent to which the educational philosophy of Christian colleges and universities is manifested in the course offerings of the curricula in terms of general education requirements for the entire student body as well as for those majoring in religion, theology, religious studies and religious education.

${ }^{168}$ Hale, Angels Watching Over Me, 218-219.

${ }^{169}$ Delbert Baker and Susan Baker, "Pathways to Success: Recruitment and Retention Methods at Oakwood College," in How Black Colleges Empower Black Students, ed. Frank W. Hale Jr. (Sterling, VA: Stylus Publishing, 2006), 143.

${ }^{170}$ Ibid., 153. 


\section{Spiritual Formation Courses in Religious/Theological Education}

\section{Spiritual Formation Courses in American Colleges and Universities}

In 1991, Charles M. Wood, retired professor of theology and administrator at Perkins School of Theology, began his insightful research by noting the "concern for, and perplexity about, the place of spiritual formation in theological education among theological students, faculty, and administration and within the churches in the last two decades. ${ }^{171}$ He concluded by asserting his conviction that theological schools must "assume their proper responsibility for spiritual formation." 172

Since that time spirituality in higher education has become of topic of growing interest even beyond the context of Christian liberal arts colleges and seminaries as documented by Astin, Astin, and Lindholm as well as Cherry, DeBerg, and Porterfield.

Robert O'Gorman, professor and graduate program director for the Master of Divinity and Pastoral Studies program at the Loyola University Institute of Pastoral Studies, suggests that the sense of spirituality as connection will be the legacy of the "postmodern" era." "173 He insists that "religious education that has spiritual formation as its characterization is an education that has a balance among reflection; action and relationship." 174 He continues, "We can no longer see education as one-sided, whether that side is action, or reflection or emotion, if we want it to be spiritual formation.

\footnotetext{
${ }^{171}$ Charles M. Wood, “'Spiritual Formation' and 'Theological Education,"' Religious Education, 86, no. 4 (1991): 550.

${ }^{172}$ Ibid., 561 .

${ }^{173}$ Robert T. O'Gorman, "Effect of Theological Orientation on Christian Education in Spiritual Formation: Toward a Postmodern Model of Spirituality," Review and Expositor 98 (Summer 2010): 351 .

${ }^{174}$ Ibid., 366.
} 
Furthermore, our struggle with God has brought us to an awareness of the vital role of education as spiritual formation. ${ }^{175}$

But the William Henry Green professor of Old Testament Literature (Emeritus) at Princeton Theological Seminary, J. J. M. Roberts, asserts that courses on spirituality and spiritual formation offered by Christian colleges and seminaries are reflections of a cultural phenomena that results in practices and teachings that are "incoherent and in some cases, even flaky."176 Further, he decries, "We simply pick and choose practices at our whim as individuals, or that as communities we adopt a practice, however foreign it is to the theology of our own tradition, because it seems neat or because it draws a crowd at some other Christian group with whom we are competing. In my opinion, such faddish or market-driven choices have no theological integrity." 177

Roberts believes that part of the problem is the biblical illiteracy and the lack of theological identity of students enrolled in Christian colleges and seminaries that creates the need for substantial remediation. ${ }^{178}$ Affirming that formation of Christian character is, by definition, a communal activity, Roberts strongly contends that it is the local church "that is the primary shaper of Christian identity"179 and that college and seminary courses in spirituality and spiritual formation are "no substitute for the local church."180

${ }^{175}$ O'Gorman, "Effect of Theological Orientation," 366.

${ }^{176}$ J. J. M. Roberts, 'Seminaries, 'Spirituality,' and 'Spiritual Formation': A Quick Fix for the Disciplined Life of Faith?” Christian Studies 20 (Fall 2004): 44.

$$
\begin{aligned}
& { }^{177} \text { Ibid., } 49 . \\
& { }^{178} \text { Ibid., } 48 . \\
& { }^{179} \text { Ibid. } \\
& { }^{180} \text { Ibid., } 50 .
\end{aligned}
$$


Differing entirely on the role and place of spiritual formation in theological education, retired professor of Christian Spirituality at Northern Baptist Theological Seminary, William Clemmons notes that "spiritual formation has had to struggle for a place in the curriculum of theological education for the past forty or fifty years." ${ }^{.181} \mathrm{He}$ quotes Henri Nouwen to emphasize the significance of theological education's formative effects:

What else is the goal of theological education than to bring us closer to the Lord our God so that we may be more faithful to the great commandment to love him with all our heart, with all our soul, and with all our mind, and our neighbor as ourselves (Matthew 22:37)? Seminaries and divinity schools must lead theology students into an ever-growing communion with God, with each other, and with fellow human beings. Theological education is means to form our whole person toward an increasing conformity with the mind of Christ so that our way of praying and our way of believing will be one. ${ }^{182}$

President emeritus of Lutheran Theological Southern Seminary, H. Frederick Reisz Jr. agrees that "spiritual formation should be an important element of theological education." ${ }^{, 183} \mathrm{He}$ underscores the importance of intentionality and assessment stating, "Schools pursuing spiritual formation as an integrated element in their mission [must be] in communication with one another... . As we create 'programs' of spiritual formation and seek to spiritually form our students, assessment of these efforts will add to their depth, breadth, utility, saliency, and validity." 184 (2004): 46 .

${ }^{181}$ William Clemmons, "Spiritual Formation in Seminary Education," Review and Expositor 101

${ }^{182}$ Henri Nouwen, Spiritual Direction: Wisdom for the Long Walk of Faith (San Francisco: JosseyBass, 2006), quoted in William Clemmons, "Spiritual Formation in Seminary Education," Review and Expositor 101 (2004): 63.

${ }^{183}$ H. Frederick Reisz Jr., "Assessing Spiritual Formation in Christian Seminary Communities," Theological Education 39, no. 2 (2003): 39.

${ }^{184}$ Ibid. 
Although specific courses in spiritual formation were not the focus of their article, a Wheaton College team of theology professors and educational ministries personnel led by David Setran, Associate Professor of Christian Formation and Ministry, developed a rationale for Christian higher education to engage in spiritual formation and to use classrelated "soul projects." 185 They define "soul projects" as "class-related 'inner work' that fosters student engagement with God"186 and are "designed to integrate spiritual formation into students' academic vocation, bringing a posture of spiritual attentiveness into the curricular sphere." 187 They posit that "in collegiate settings where creating space for the Holy Spirit seems more challenging than ever, soul projects have the potential to create contexts in which students are directed to "pay attention" to their subjects, to their peers, to their souls, and, ultimately, to Christ and His call upon their lives."188

And Mark Maddix, Professor of Christian Education and Dean of the School of Theology and Christian Ministries at Northwest Nazarene University, and James Estep, seminary professor of Christian Education at Lincoln Christian University, address the commitment of Christian higher education to the spiritual formation of students in the context of online instruction. The relationship of spiritual formation courses to university students will be discussed in a subsequent section of this chapter but the authors "framed the notion of online spiritual formation as a participatory endeavor in an online format

\footnotetext{
${ }^{185}$ David P. Setran, Jim Wilhoit, Donald Ratcliff, Daniel T. Haase, and Linda Rosema, "Spiritual Formation Goes to College: Class-Related 'Soul Projects' in Christian Higher Education," Christian Education Journal 7, no. 2 (2010): 401.

${ }^{186}$ lbid.

${ }^{187}$ Ibid.

${ }^{188}$ Ibid.
} 
that is supplemental, not a substitute, to a holistic approach to spiritual formation."

\section{Spiritual Formation Courses at American SDA \\ Colleges and Universities}

Because this research endeavor focuses on the influence of a spiritual formation course on the perspectives of African American Oakwood University students on Sabbath and Sabbathkeeping as a spiritual discipline, online investigation of all Seventh-day Adventist Christian colleges and universities in the United States was undertaken. At the conclusion it was evident that all of them include religious and theological courses as general education requirements for undergraduate degrees, often mandating one religion course for each year in residence, usually totally twelve credit hours. In addition, all the aforementioned institutions, with the exception of Southwestern Adventist University, offer at least one undergraduate course in spiritual formation with some providing four courses (undergraduate and graduate) on this subject. Courses in biblical spirituality and spiritual formation at the Seventh-day Adventist Christian colleges and universities in the United States that follow are identified by course title, academic level, degree program, and the related institution.

Andrews University offers an undergraduate course for Bachelor of Arts and Bachelor of Science degrees entitled RELT250: "Personal Spirituality and Faith." For the Doctor of Ministry degree the Seventh-day Adventist Theological seminary offers GSEM 706: "Spiritual and Theological Foundations for Ministry," DSRE705: Theological and Historical Perspectives on Spiritual Growth," DSRE707: "Personal

\footnotetext{
${ }^{189}$ Mark A. Maddix and James R. Estep, "Spiritual Formation in Online Higher Education Communities: Nurturing Spirituality in Christian Higher Education Online Degree Programs," Series 3 , Christian Education Journal 7, no. 2 (2010): 433.
} 
Practice of Biblical Spirituality," DSRE708: "Mentoring for Discipleship and Biblical Spirituality," and DSRE709: "Constructs of Corporate Ministry for Discipleship and Biblical Spirituality."

The Master of Arts degree in Pastoral Ministry offered by the seminary at Andrews University includes CHMN616: "Spirituality in Ministry," CHMN618: "The Practice of Spirituality," DSRE541: "Foundations of Biblical Spirituality," DSRE542: "Advanced Foundations of Biblical Spirituality," and DSRE678: "Spiritual Nurture of Children."

Although the Master of Arts degree in Religion offered by the seminary at Andrews University requires no courses in biblical spirituality or spiritual formation, the Master of Arts degree in Religious Education includes DSRE541: "Foundations of Biblical Spirituality" and DSRE610: "Teaching for Discipleship."

The curricula for both the Master of Arts degree in Youth and Young Adult Ministry and the Master of Arts dual degree in Youth and Young Adult Ministry and Social Work offered at Andrews University include DSRE541: "Foundations of Biblical Spirituality," DSRE610: "Teaching for Discipleship," and CHMN616: "Spirituality in Ministry."

To earn the Master of Divinity degree from the seminary at Andrews University, students are required to complete DSRE541: "Foundations of Biblical Spirituality," and CHIS629: "History of Christian Spirituality."

Students pursuing a Master of Science degree in Church Administration are required to take GSEM541: "Foundations of Biblical Spirituality" 
For the Doctor of Philosophy degree in Religious Education the seminary at Andrews University offers DSRE/RLED678: "Spiritual Nurture of Children," DSRE/RLED830: "Fostering Spiritual Growth," and DSRE/RLED930: "Seminar in New Testament Spirituality."

No courses in biblical spirituality/spiritual formation are required for students pursuing Doctor of Philosophy degrees in Religion, Theology, or Biblical and Ancient Near Eastern Archaeology at the seminary at Andrews University.

Florida Hospital College of Health Sciences includes RELP245: "Introduction to Spiritual Disciplines" and RELP374: "Spiritual Dimensions of Healthcare" as General Education Requirements for all students.

At Kettering College of Medical Arts RELB123: "Spiritual Formation" is an option from the "Spiritual Foundations Cluster" from which all Associate of Arts and Associate of Science degree candidates are required to choose. To earn a Bachelor of Science degree, students must also complete RELP315: "Spirituality in Healing and Health Care."

Among the core requirements for undergraduate students matriculating at $\mathrm{La}$ Sierra University are courses from the "Spiritual Experience and Expressions Cluster" that include RELT464: "Religious Development and Nurture." At the Graduate School of Religion, core requirements include RELP589: "Christian Spiritual Resources." An optional elective offered is RELP616: "Seminar in Spiritual Formation."

Pacific Union College includés RELP235: "Spiritual Formation" as a core requirement for a baccalaureate degree while Union College requires RELP149: 
"Dynamics of Christian Living" and offers RELT205: "Developing the Christian Mind" as one of the twelve hours in Religion needed for an undergraduate degree.

Among the core requirements for bachelor's degree from Washington Adventist University are religion electives that include RELP226: "Christian Spiritual Formation for Ministry." The Master of Arts degree in Religion requires RELP618: "Foundations of Christian Spirituality."

At Walla Walla University, except for engineering and nursing majors, students who are seeking a baccalaureate degree must complete general studies requirements of 16-20 hours in religion and theology. One course elective is RELT326: "Spirituality and Discipleship." None of the graduate degree programs require courses in spiritual formation or biblical spirituality although the curriculum for the Master of Social Work degree includes SOWK508: "Social Work and Religion" which examines the role of spirituality in social work practice.

The core curricula of all Loma Linda University's degree program include religion courses. While there are no core requirements of courses in biblical spirituality or spiritual formation, there are eight elective courses that focus on this subject matter including RELR535: "Spirituality and Mental Health," RELR536: "Spirituality and Everyday Life," RELR586: “Psychology of Moral and Faith Development," RELR588: "Personal and Family Wholeness," RELT475: "Spirituality and the Contemporary Christian," RELT556: "Spirituality in Seventh-day Adventist Theology," RELT713: "Christian Spirituality," and RELT775: "Spirituality and the Christian Health Professional." 
At Southern Adventist University all bachelor's degree students must take either RELB125: "Life and Teachings of Jesus" or RELT176: "Christian Spirituality." Core requirements for the Master of Ministry degree include RELT520: "Spirituality in Ministry" although neither the Master of Arts degree in Biblical and Theological Studies nor the Master of Arts degree in Religious Studies require any course work in biblical spirituality or spiritual formation.

Oakwood University offers two relevant courses on the undergraduate level although neither is required for the general student population and one of them must be taken as a prerequisite for the graduate program in pastoral studies. The courses are RP131: "Spiritual Formation for Ministry" and RG201: "Dynamics of Christian Living."

\section{Spiritual Formation of Collegians/Emerging Adults}

The spiritual formation/development of college students constitutes an important, yet understudied topic in higher education research. In particular, very little is known about the influence of specific types of course work or particular courses in the curricula of religious and theological education.

David Setran and his Wheaton College-based research team pose a critical perspective on the nature of spirituality or spiritual formation desired and/or embraced by college students and other emerging adults. They observe that "while the HERI study speaks optimistically about the spiritual proclivity of collegians, scholarship related to a distinctly Christian spiritual formation is a bit more troubling." 190

In his scholarly research about the religious and spiritual lives of emerging adults,

${ }^{190}$ Setran et al., "Spiritual Formation Goes to College," 402. 
Christian Smith substantiates this concern. He found that for most of the 18-23 year olds who were the subjects of his study "religious beliefs are cognitive assents, not life drivers." 191 He asserts that the real religion of American youth is "moralistic therapeutic deism" (MTD) and presents the five key beliefs held by followers of MTD.

First, a God exists who created and ordered the world and watches over human life on earth. Second, God wants people to be good, nice, and fair to each other, as taught in the Bible and by most world religions. Third, the central goal of life is to be happy and to feel good about oneself. Fourth, God does not need to be particularly involved in one's life except when God is needed to resolve a problem. Fifth, good people go to heaven when they die. ${ }^{192}$

Further his research revealed that "according to emerging adults, the absolute authority for every person's beliefs or actions is his or her own sovereign self.",193

Chair of the Sociology Department at Princeton University, Robert Wuthnow provides empirical data on the religious and spiritual views, practices and commitments of post-Baby Boomer generations and from that information makes recommendations to clergy and laity about the future of American religion. His findings indicate that "the majority of younger adults either attend religious services rarely or, if they attend more than that, are hardly regular enough to be the core of any congregation."194 A statistical decline of note is the fact that "regular attenders now characterize only 25 percent of younger adults, whereas this proportion was 31 percent in the 1970s."195

${ }^{191}$ Christian Smith, Souls in Transition: The Religious and Spiritual Lives of Emerging Adults (New York: Oxford University Press, 2009), 154.

${ }^{192}$ Ibid.

${ }^{193}$ Ibid., 49.

${ }^{194}$ Robert Wuthnow, After the Baby Boomers: How Twenty-and Thirty-Somethings Are Shaping the Future of American Religion (Princeton, NJ: Princeton University Press, 2007), 53.

${ }^{195}$ Ibid. 
Additionally, "younger adults make up a smaller proportion of the adherents of. several faith traditions now than they did a generation ago,"196 although differences exist when denominations are compared (Protestant vs. Catholic; mainline Protestant vs. evangelical Protestant; historically black Protestant vs. white Protestant; Christian vs. Jewish; Christian vs. non-Western religious traditions: Hinduism, Buddhism, Islam, etc.). ${ }^{197}$ Wuthnow also found that "among young adults in their twenties, about a quarter never pray, and a majority never read the Bible or meditate, ${ }^{198}$ although "about a third of young adults believe firmly that the Bible is the divine and literal word of God."199 The study asks the subjects to choose between church doctrine and personal experience as the best way to understand God and "young people overwhelmingly opt for personal experience over church doctrines."200

The forms and patterns of contemporary college student spirituality were studied by Jon Dalton, Associate Professor of Higher Education and Director of the Hardee Center for Leadership and Ethics at Florida State University, and a cohort of graduate student researchers who identified two primary forms of spiritual search. "One form of spiritual search is oriented inside the context of religion, either a specific religious faith tradition or a multi-faith context, and the other form of spiritual search occurred outside a direct connection to any particular religion or religions and utilized a non-religious or

\footnotetext{
${ }^{196}$ Wuthnow, After the Baby Boomers, 73.

${ }^{197}$ Ibid.

${ }^{198}$ Ibid., 128.

${ }^{199}$ Ibid., 132.

${ }^{200}$ Ibid., 133 .
} 
secular approach in the search for spiritual meaning and purpose."201

They also determined that there were four types of college student spiritual seekers in two categories: Religious Seekers and Secular Seekèrs.

Faith centered seekers are those who engage in spirituality solely within the context of their own particular religious tradition while multi-religious seekers are those who seeks to deepen their religious spirituality through interfaith and multi-religious exploration, dialogue and practice. Mindfulness seekers focused in their inner search on ways to heighten self-awareness and understanding and wellness seekers engaged in spirituality activities in order to achieve a more holistic, healthy and integrated way of life. ${ }^{202}$

Additionally, they observed that "most of the types of search among college students were of the solitary type."203

George Kuh, Chancellor's Professor Emeritus of Higher Education and founding Director of the Center for Post-Secondary Research and the National Survey of Student Engagement, and Robert Gonyea, Associate Director of the Center for Post-Secondary Research, both of Indiana University, report that "students who frequently engage in spirituality-enhancing practices also participate more in a broad cross-section of collegiate activities." 204

David Kinnaman, president of the Barna Group, and Gabe Lyons, founder of Q, a learning community that mobilizes Christians to advance the common good in society, spent three years studying what they considered to be Christianity's image problem. A

\footnotetext{
${ }^{201}$ Jon C. Dalton, David Eberhardt, Jillian Bracken, and Keith Echols, "Inward Journeys: Forms and Patterns of College Student Spirituality," Journal of College and Character 7, no. 8 (2006): 6.

${ }^{202}$ Ibid., 7.

${ }^{203}$ Ibid., 8 .

${ }^{204}$ George D. Kuh and Robert M. Gonyea, "Spirituality, Liberal Learning and College Student Engagement," Liberal Education 92, no. 1 (2006): 44.
} 
major component of the study was a series of interviews with 16-29 year olds and they found that "many of those outside of Christianity, especially younger adults, have little trust in the Christian faith, and esteem for the lifestyle of Christ followers is quickly fading among outsiders." 205 Like Smith, they concluded that many young adults consider spirituality as "just one element of a successful, eclectic life." "206 "Fewer than one out of ten young adults mention faith as their top priority, despite the fact that the vast majority of Busters [born between 1965 and 1984] and Mosaics [born between 1984 and 2002] attended a Christian church during their high school years."207

Even more alarming is the rapid decline in the perceptions of young adults about Christianity during the ten years preceding their study.

These days nearly two out of every five young outsiders ( 38 percent) claim to have a "bad impression of present-day Christianity." Beyond this, one-third of young outsiders said that Christianity represents a negative image with which they would not want to be associated. Furthermore, one out of every six young outsiders (17 percent) indicates that he or she maintains "very bad" perceptions of the Christian faith. Though these hard-core critics represent a minority of young outsiders, this group is at least three times larger than it was just a decade ago. ${ }^{208}$

Gabe Lyons, however, in the wake of the research he commissioned that became the book, UnChristian, holds out optimism that Christianity's best days are yet to come in his subsequent book, The Next Christians: The Good News About the End of Christian America. He describes Christian interaction with current culture as being in one of two

\footnotetext{
${ }^{205}$ David Kinnaman and Gabe Lyons, Unchristian: What a New Generation Really Thinks About Christianity ... And Why It Matters (Grand Rapids, MI: Baker Books, 2007), 11.

${ }^{206}$ Ibid., 23.

${ }^{207} \mathrm{Ibid}$.

${ }^{208}$ Ibid., 24.
} 
categories: Separatist or Cultural. ${ }^{209}$ The Separatist camp includes those he defines as Insiders, Culture Warriors and Evangelizers while the Cultural group is made up of Blenders and Philanthropists. But he asserts that the new generation of Christians will be belong to neither camp but will introduce a new way of interacting with current culture as Restorers. ${ }^{210}$ Lyons identifies the characteristics that set Restorers apart as Provoked, not Offended; Creators, not critics; Called, not employed; Grounded, not distracted; In Community; not alone; and Countercultural, not relevant. ${ }^{211}$

Conrad Cherry, Betty A. DeBerg, and Amanda Porterfield undertook researching the study and practice of religion on four college campuses in the United States, as they were "prompted by a desire to test the adequacy of secularization theories as measures of the importance of religion on the contemporary campus. 212 Pseudonyms for the subject campuses were West University (a large, public, state university), North College (a Lutheran liberal arts college); East University (a Roman Catholic school); and South University (a historically black college at one time a denominational institution that now defines itself as a private, non-denominational school with Presbyterian roots). At the conclusion of their observations on the ethos, religious practice, and teaching of religion at the four institutions, they found, "religion on the four campuses sufficiently vital and inviting to make us wonder if it had ever been more so in the past. It is possible

\footnotetext{
${ }^{209}$ Gabe Lyons, The Next Christians: The Good News About the End of Christian America (New York: Doubleday, 2010), 31.

${ }^{210}$ Ibid., 46.

${ }^{211}$ Ibid., 67.

${ }^{212}$ Conrad Cherry, Betty A. DeBerg, and Amanda Porterfield, Religion on Campus (Chapel Hill, NC: The University of North Carolina Press, 2001), 4.
} 
that young people in American culture have never been more enthusiastically engaged in religious practice or with religious ideas. ${ }^{213}$

Barbara Walvoord begins her article entitled "Students' Spirituality and 'Big Questions' in Introductory Religion Courses" with the following words: "Students enrolled in introductory general-education theology or religion courses, whether in nonsectarian or religiously affiliated institutions, often want to use the course to develop their own spiritual and religious lives and to address their own "big questions" about the meaning of life. ${ }^{214}$

Her assertion supports the findings of the HERI study but Ronald Welch and Kimberlee Mellberg found that "female students experienced more spiritual benefits from Christian college attendance than male students." ${ }^{215}$ So they suggest

males and females could be placed in separate discipleship groups to address the different ways that they mature spiritually, with the groups focusing on the unique experiences of each gender. In these ways, the different development experiences that males and females ... have could be addressed in the Christian university experience. $^{216}$

Furthermore, "classroom environment changes that encourage intellectual, moral and epistemological development would be beneficial in this regard."217

After studying how faculty can employ four student voices (the Questioner, the Applier, the Thinker/Arguer and the Spiritual Autobiographer) to explicitly put students'

\footnotetext{
${ }^{213}$ Cherry et al., Religion on Campus, 294-295.

${ }^{214}$ Barbara E. Walvoord, “Students' Spirituality and 'Big Questions' in Introductory Religion Courses," Teaching Theology and Religion 11, no. 1 (2008): 13.

${ }^{215}$ Welch and Mellberg, "Spiritual Maturation and Religious Behaviors," 157.

${ }^{216}$ Ibid., 159-160.

${ }^{217}$ Ibid., 159.
} 
own religious and spiritual lives into relationship with the course material and critical thinking, Walvoord concludes that it is possible to help students relate religion courses to their own spiritual and religious lives, provided that careful consideration is given to what is to be accomplished, how students are to be guided and how one shapes one's responses. $^{218}$

Spiritual formation is inherently communal in nature so one might understandably wonder how community can be created at a distance. But the case is made by Maddix and Estep that "distant and online learning, built on student and faculty discussion, has proven to develop community and formation. These learning communities are developing significance relationships with peers and with God."219 Northwest Nazarene University offers a Master of Arts degree in Spiritual Formation fully online.

The online courses are built on a robust learning community that includes daily discussion and dialogue with students and professors.... We contextualize learning through students having a mentor/spiritual director during the program... We have developed our online programs in cohort (learning community) format. Learning communities consist of 15-20 students who take only one course at a time. The courses are condensed in a 6- or 8-week formal. ... Students self-report that the online learning community (cohort) approach provides a safe context for them to share their ministry experiences and personal concerns. ${ }^{220}$

In his book, The Emerging Church: Vintage Christianity for New Generations, Dan Kimball, primary teaching pastor of Vintage Faith Church in Santa Cruz, California (designed to specifically connect with the emerging culture of Santa Cruz), addresses the shifting values in approach to spiritual formation. He contends that as compared to the

\footnotetext{
${ }^{218}$ Walvoord, "Students' Spirituality and 'Big Questions'," 3.

${ }^{219}$ Maddix and Estep, "Spiritual Formation in Online Higher Education Communities," 425.

${ }^{220}$ Ibid., $430-431$.
} 
modern church where spiritual formation primarily occurs through presentation and teaching, in the emerging church spiritual formation primarily occurs through experience and participation. ${ }^{221}$ His analysis points to the necessity for students to participate in service-learning as a required component of spiritual formation courses.

The use of edifying stories, parables, novels, journals, hag̀iographies, spiritual autobiographies, films, short stories, and plays to foster the spiritual formation of students is advocated by Richard Steele, Chair of the Department of Theology at Seattle Pacific University, insisting that "the fundamental premise of Christian higher education is that students are never 'sufficiently edified'." 222

Echoing the element to incorporate the symbolic, spiritual and imaginative domain is Fredericka Berger from the Center for the Arts and Religion at the Wesley Theological Seminary in Washington, DC. Berger, encouraging the inclusion of plays of literary merit to be included in seminary curricula and in religious education, ${ }^{223}$ argues "this is more subtle, but no less a mode of learning through drama. This will not be learning that can be translated directly into insights about human behavior. This is an awakening to the aesthetic. This learning is given too little attention in our religious institutions despite the fact that it provides a well validated channel to spirituality."224

\footnotetext{
${ }^{221}$ Dan Kimball, The Emerging Church: Vintage Christianity for New Generations (Grand Rapids, MI: Zondervan Publishing Company, 2003), 217.

${ }^{222}$ Richard B. Steele, "'Sufficiently Edified" - The Use of Stories in the Spiritual Formation of College Students," Horizons 31, no. 2 (2004): 353.

${ }^{223}$ Fredericka Berger, "Spiritual Formation through Drama," ARTS 15, no. 1 (2003): 34. ${ }^{224}$ Ibid., 35.
} 
Professor Stella Ma, formerly of Biola University and Logos Evangelical Seminary, studied the impact of the Christian college educational environment, both academic and nonacademic, on student spirituality and found that "the nonacademic aspects of college life were perceived to be more influential on spiritual formation than the academic. For example, students rated their peer relationships as being most significant to their spiritual growth."225

\section{Spiritual Formation of African American Collegians/Emerging Adults}

If it can be said that the spiritual formation of college students has until recently been an overlooked field of inquiry, then it is even more the case that research on the spiritual development of African American collegians is neglected. To put the subject in context, some, like Julianne Malveaux, lament what appears to be the vanishing of black students on college and university campuses, ${ }^{226}$ while others, like Bakari Kitwana, cite Department of Justice statistics that "more Black men 18-25 years old are in prison than in college. 227

From a historical perspective, "African and African American culture and religion have shaped and nurtured the spirituality of black spirituality. . . Black religious life, community life and social existence are tied together into one whole," 228 conclude

\footnotetext{
${ }^{225}$ Stella Ma, "The Christian College Experience and the Development of Spirituality Among Students," Christian Higher Education 2, no. 3 (2003): 321.

${ }^{226}$ Julianne Malveaux, "Vanishing Black College Students?” Black Issues in Higher Education 21, no. 24 (2005): 35 .

- ${ }^{227}$ Bakari Kitwana, The Hip-Hop Generation: Young Blacks and the Crisis in African-American Culture (New York: Basic Civitas Books, 2002), 109.
} 
Michael Dash and Stephen Rasor. They propose African American spirituality as having "three dynamic and interconnecting components of a liberating encounter, a liberating reflection and liberating action."229

Although most of the research that addresses spirituality and African American college students have non-academic foci such as health and student services, they are often helpful in presenting the spiritual and/or religious realities of this population.

Dixie Dennis and her research team used the Life Attitude Profile-Revised to determine the degree of spirituality among 430 predominantly (90\%) African American undergraduates at a historical black university. ${ }^{230}$ Their results showed that these students scored higher than their white counterparts ${ }^{231}$ and there were no significant gender differences in scoring. ${ }^{232}$ "This study does not address what African American students do with their moderately high degree of spirituality."233

One hundred seventy-one African American university students from two large institutions were sampled by LaVerne Berkel, Tonya Armstrong, and Kevin Cokley to explore similarities and differences between religiosity and spirituality. ${ }^{234}$ They found

${ }^{228}$ Michael I. N. Dash and Stephen C. Rasor, "African American Spirituality: Some Biblical and Historical Resources for Reflection," Ex auditu 18 (2002): 135.

${ }^{229}$ Ibid., 124.

${ }^{230}$ Dixie L. Dennis, Terence Hicks, Priya Banerjee, and Brent G. Dennis, "Spirituality Among Predominantly African American College Student Population," American Journal of Health Studies 20, nos. 3/4 (2005): 136.

$$
\begin{aligned}
& { }^{231} \text { Ibid., } 135 . \\
& { }^{232} \text { Ibid., } 138 . \\
& { }^{233} \text { Ibid., } 140 .
\end{aligned}
$$

${ }^{234}$ LaVerne A. Berkel, Tonya D. Armstrong, and Kevin O. Cokley, "Similarities and Differences Between Religiosity and Spirituality in African American College Students: A Preliminary Investigation," Counseling and Values 49 (2004): 4. 
that 76 percent were affiliated with a particular denomination or faith; that the number of religious services attended in a year was less than 50 ; that the students rated the importance of religion 5.4 out of 7 and rated a relationship with a Supreme Being 6 out of $7^{235}$

In a study of African American college males matriculated at a predominantly white institution, Michael Herndon, Director of Summer Sessions at Virginia Tech and formerly Director of Undergraduate Studies in the Department of Interdisciplinary Studies at Virginia Tech, found that "spirituality bolsters resilience, provides a sense of purpose, and enhances persistence. ${ }^{236}$

Her interest in how African American college women use spirituality prompted study by Sherry K. Watt. Using focus group interviews and the Optimal Theory Applied to Identity Development (OTAID) model created by Linda James Myers, she found that "the OTAID model actually describes the processes of spiritual and identity development",237 for this population and concluded that spirituality-_"an integral part of identity development" 338 - helped the 48 participants to "cope, psychologically resist [negativity] and develop their identity."239

Despite the unfortunate absence of research on this topic, Gallien and Jackson,

${ }^{235}$ Berkel et al., "Similarities and Differences Between Religiosity," 4-5.

${ }^{236}$ Michael K. Herndon, "Expressions of Spirituality Among African-American College Males," Journal of Men's Studies 12, no. 1 (2003): 75.

${ }^{237}$ Sherry K. Watt, "Come to the River: Using Spirituality to Cope, Resist, and Develop Identity," New Directions for Student Services 104 (2003): 35.

$$
\begin{aligned}
& { }^{238} \text { Ibid., } 34 . \\
& { }^{239} \text { Ibid., } 35 .
\end{aligned}
$$


addressing character development from African-American perspectives, argue that "tackling the daunting task of character education requires awareness, merging the stages of racial identity development with Afrocentric principles, providing a culturallyresponsive context and exposing the more nihilistic and relativistic value base of the commercialized hip-hop movement to our African American youth."240 Because "the scope of peer influence has multiple access points, reform efforts must target the information-input sources when addressing moral education initiatives ${ }^{\$ 241}$ and these researchers conclude that "by taking each of these components, educators, clinicians, parents and neighbors can integrate the psychological, spiritual and academic development of our next generation."242

\section{Influence of Spiritual Disciplines on Collegians/Emerging Adults}

While there is no exhaustive list of spiritual disciplines, some figure more prominently in the literature than others.

Richard J. Foster develops a threefold typology of inward disciplines (meditation, prayer, fasting and study), outward disciplines (simplicity, solitude, submission and service), and corporate disciplines (confession, worship, guidance and celebration). Dallas Willard divides the disciplines into two classes: disciplines of abstinence (solitude, silence, fasting, frugality, chastity, secrecy and sacrifice) and disciplines of engagement (study, worship, celebration, service, prayer, fellowship, confession and submission). Other writers categorize other activities, including journaling, dialogue, witness, stewardship and listening, as disciplines. ${ }^{243}$

Citations that follow address spiritual disciplines practiced by American college

\footnotetext{
${ }^{240}$ Gallien and Jackson, "Character Development from African-American Perspectives," 136-137.

${ }^{241}$ Ibid.

${ }^{242}$ Ibid.

${ }^{243} \mathrm{Boa}$; Conformed to His Image, 82.
} 
and university students in the twenty-first century.

Jon Dalton's study of the inner journeys of college students revealed that some disciplines or practices are closely connected to particular kinds of spirituality.

Bible study (or the study of other sacred texts) is a spiritual practice closely associated with religious spirituality. The Bible is a sacred religious text that is read by believers as a way of examining and deepening one's faith. Many spiritual practices are of this nature such as prayer, worship, Bible study, interfaith dialogue, religious ritual observances, etc. Similarly, there are other practices more closely associated with secular spirituality. Meditation, for example, is a practice that is often used for focusing spiritual awareness, but it is usually non-religious or secular in context. Other practices such as contemplation; mindfulness, yoga, and labyrinth walks are often employed with secular spiritual search.

However, many if not most of the collegiate spiritual activities we identified can be employed with both religious and secular spiritual search. The reason is that many of these activities can support the process of spiritual search without necessarily conveying specific religious or secular content. These activities include meditation, contemplation; labyrinths, sacred space, nature retreats, spiritual retreats, yoga, and fitness-wellness exercises. ... The intent of the spiritual seeker is what determines whether the activity is utilized for religious or non-religious purposes. ${ }^{244}$

Judging from their responses to the entering freshmen survey, Astin, Astin, and Lindholm found college students to be "a pretty religious lot."245 "Four out of five (80\%) attended religious services during the year prior to entering college (44\%) attended frequently . . . and more than two-thirds (69\%) pray." ${ }^{246}$ In fact, they state that "it appears that for many college students, increasingly active engagement in spiritual questing is a natural part of their young adult development.".247

In their study of men's spirituality groups at Saint John's University, W. Merle Longwood, Mark Muesse, and William Schipper, sought to learn how these groups

\footnotetext{
${ }^{244}$ Dalton et al., "Inward Joumeys," 8.

${ }^{245}$ Astin et al., Cultivating the Spirit, 83.

${ }^{246}$ lbid.

${ }^{247}$ Ibid., 36.
} 
influenced the participants in the following ways: "(1) self-understanding as men, (2) relationships with others outside the group, (3) sense of spirituality, (4) sense of justice and compassion, and (5) sense of vocation." ${ }^{248}$ Among other findings, they discovered that "in all the groups participants expressed enthusiasm about how they had been able to focus on spirituality, which they defined broadly and distinguished from institutional religion."249 And "many men indicated how good it was to know that others are also serious about their faith."250

Reflecting on his own collegiate experience of service learning, Kent Koth, Service Learning Program Coordinator at the Haas Center for Public Service at Stanford University, pondered connecting service experiences with a deepened sense of spirituality as one way for students to hold on to their commitments to public service after graduation. ${ }^{251} \mathrm{He}$ highlights the role of reflection in the connection between service and learning, ${ }^{252}$ noting how "service-learning reflection allows student to analyze their service experiences in the context of social and academic issues." "Such reflections also involve a spiritual component that steers students to intentionally examine the deeper meaning of their experiences and their lives. Thus the service experience becomes a

\footnotetext{
${ }^{248}$ W. Merle Longwood, Mark W. Muesse, and William Schipper, "Men, Spirituality, and the Collegiate Experience," New Directions for Student Services 107 (2004): 90.

${ }^{249}$ Ibid., 91 .

${ }^{250}$ Ibid., 91-92.

${ }^{251}$ Kent Koth, "Deepening the Commitment to Serve: Spiritual Reflection in Service Learning," About Campus 7, no. 6 (2003): 3.

${ }^{252}$ Ibid., 5.

${ }^{253}$ Ibid., 6.
} 
gateway into further exploration of personal values, vocational calling and the cultivation of a spiritual identity.,254

Chaplain to Susquehanna University, Mark Radecke brilliantly makes the case for faith-based service learning in the spiritual formation of college students. He asserts that "experiences that take emerging adults out of their comfort zone and immerse them in unfamiliar surroundings enable them to view the world, themselves, God, and the things of God in new and refreshing ways." 255

Sensitive to the developmental and affiliative needs of emerging adults, he states, Those who design and lead faith-based service learning events can provide rich and potentially transformative experiences. These can be curricular (one could envision a partnership between a congregation and a college so that academic credit could be awarded) or co-curricular. The precise results are unknowable in advance; that is part of the wonder and excitement of it all. Changes in the areas of behavior and clarification of vocation are likely to be modest. With regard to perspective transformation, however, the research is clear: participants in service-learning events where service, learning, and reflection are highly integrated routinely report epiphanies great and small as their perspectives are changed. ${ }^{256}$

In their article "Outcomes of a Spiritually Focused Wilderness Orientation Program," Andrew Bobilya, Co-Chair of the Outdoor Education Department at Montreat College; Lynn Akey, Assistant to the Vice President for Student Affairs at Minnesota State University; and Donald Mitchell, Pre-Doctoral Fellow at Minnesota State University describe another edifying aspect of spiritual formation as they detail a unique

${ }^{254}$ Koth, "Deepening the Commitment to Serve," 6.

${ }^{255}$ Mark Wm. Radecke, "Service-Learning and the Spiritual Formation of College Students," Word \& World 26, no. 3 (2006): 289.

${ }^{256}$ Ibid., 298. 
way to "support students in their transition to college life."257

The following major themes emerged from the qualitative data collected both through the post-expedition essays and the focus group interview at the end of the Semester:

(a) the wilderness journey establishes community; (b) the wilderness journey facilitates developing competence; (c) the wilderness journey enhances a sense of stewardship-responsibility to care; (d) the wilderness journey promotes spiritual development through an increased trust in God, an increased communion with God, an increased awareness of one's personal faith, and an environment that supports faith development. ${ }^{258}$

Although the wilderness orientation spans 12-14 days and occurs prior to the regular New Student Orientation at Montreat College, other educational institutions are certainly able to modify duration, placement and location of "open spaces at the depths where the Spirit of God may descend and dwell" ${ }^{p 59}$ for the spiritual formation of students.

\section{Influence of Spiritual Disciplines on African American Collegians}

Once again, it is disheartening that so little scholarship has been devoted to the study of the spiritual practices utilized by African American college and university students; however, three studies are cited as indicators of contemporary spiritual exercises that are common within this constituency.

Using the Spiritual Well-Being Scale to assess spirituality which is divided into the two subscales of existential well-being and religious well-being, Jocelyn TurnerMusa, Associate Professor at Morgan State University, and La'Shaunna Lipscomb, graduate student, studied the religious affiliation and practices of 211 African American

\footnotetext{
${ }^{257}$ Andrew J. Bobilya, Lynn Akey, and Donald Mitchell Jr., "Outcomes of a Spiritually Focused Wilderness Orientation Program," Journal of Experiential Education 31, no. 3 (2009): 440.

${ }^{258}$ Ibid., 442.

${ }^{259}$ Cornelius Plantinga, Engaging God's World: A Christian Vision of Faith Learning and Living (Grand Rapids: Wm. B. Eerdmans, 2002), 125.
} 
students from a historically black university. ${ }^{260}$ Most were freshmen, single, residential students who identified as Baptist, attended church at least once a month, prayed at least four times a week, listened to religious music at least fifteen minutes a week but did not read religious materials. ${ }^{261}$

Reginald Riggins, graduate student in clinical psychology at Jacksonville State University, with two other researchers studied the role of spirituality among AfricanAmerican college males attending a historically black university and found that $85 \%$ pray, $31 \%$ read the Bible, and $23 \%$ pray. ${ }^{262}$

Collaborating in the study of the impact of church participation on African American college students enrolled at two rural universities, Saran Donahoo and Ronald Caffey, both assistant professors at Southern Illinois University-Carbondale, found that $88 \%$ reported attending church while in college. ${ }^{263}$

\section{Influence of the Spiritual Discipline of Sabbath/Sabbathkeeping}

Again, for the purposes of this research project, the term "spiritual discipline" is defined as "the means to godliness" 264 based on my understanding and appreciation of 1 Timothy 4:7 (NASB) which reads "Discipline yourself for the purpose of godliness." So

\footnotetext{
${ }^{260}$ Jocelyn Turner-Musa and La'Shaunna Lipscomb, "Spirituality and Social Support on Health Behaviors or African American Undergraduates," American Journal of Health Behavior 31, no. 5, (2007): 496.

${ }^{261}$ Ibid., 497-498.

${ }^{262}$ Reginald K. Riggins, CoSandra McNeal, and Michael K. Herndon, "The Role of Spirituality Among African American College Males Attending a Historically Black University," College Student Journal 42, no. 1 (2008): 79.

${ }^{263}$ Saran Donahoo and Ronald A. Caffey, "A Sense of Home: The Impact of Church Participation on African American College Students," Journal of Research on Christian Education 19 (2010): 91.

${ }^{264}$ Whitney, Spiritual Disciplines for the Christian Life, 15.
} 
although the terminology or use of the words "spiritual discipline" does not appear in all the foregoing citations, it is clear from their content that the substance of the spiritual discipline of Sabbath and Sabbathkeeping as well as its influence is satisfied.

\section{Jewish Perspective}

The Jewish perspective on the influence of the spiritual discipline of Sabbath and Sabbathkeeping can probably find no more eloquent expression than that of former Associate Professor of Jewish Ethics and Mysticism at the Jewish Theological Seminary of America, Abraham Joshua Heschel who describes it as follows:

We must conquer space in order to sanctify time. All week long we are called upon to sanctify life through employing things of space. On the Sabbath it is given us to share in the holiness that is in the heart of time. Even when the soul is seared, even when no prayer can come out of our tightened throats, the clean, silent rest of the Sabbath leads us to a realm of endless space, or to the beginning of an awareness of what eternity means. There are few ideas in the world of thought which contain so much spiritual power as the idea of Sabbath. Aeons hence, when of many of our cherished theories only shreds remain, that cosmic tapestry will continue to shine. Eternity utters a day. ${ }^{265}$

First-day Christian Perspectives

The influence of Sabbath and Sabbathkeeping as a spiritual discipline from the perspective of first-day Christians are diverse and significant in the understanding of its importance.

Author Lynne M. Baab suggests that in order to experience the influence of Sabbath and Sabbathkeeping as a spiritual discipline one must "slow down and engage in

\footnotetext{
${ }^{265}$ Abraham Joshua Heschel, The Earth Is the Lord's and the Sabbath (New York: Harper \& Row, 1966), 101.
} 
"activities that nurture peace, worship, relationships, celebration and thankfulness."266

Spiritual director and retreat leader Ruth Haley Barton agrees that the influence of the spiritual discipline of Sabbath and Sabbathkeeping is "resting the body, replenishing the spirit and restoring the soul.,267

In the January 2005 edition of Interpretation: A Journal of Bible and Theology, Dorothy Bass, Director of The Valparaiso Project on the Education and Formation of People in Faith, espouses keeping Sabbath as formative of "persons and communities in faith and fosters resistance to distorted ways of living and inadequate views of human identity that are implicit in the culturally dominant experience of time.”268 She states, "To keep Sabbath is to practice receptivity, to open ourselves to the grace of God and to offer in grateful return only ourselves."269

Pastor Mark Buchanan makes an argument for the influence of the spiritual discipline of Sabbath and Sabbathkeeping as a form of mending.

God made us from dust. We are never far from our origins. The apostle Paul says we're only clay pots-dust mixed with water, passed through fire. Hard, yes, but brittle too. Knowing this, God gave us the gift of Sabbath-not just as a day, but as an orientation, a way of seeing and knowing. ... It's mortar in the joints. Keep Sabbath, or else break too easily, and oversoon. Keep it, otherwise our dustiness consumes us, becomes us and we end up able to hold exactly nothing. ${ }^{270}$

\footnotetext{
${ }^{266}$ Lynne M. Baab, Sabbath Keeping: Finding Freedom in the Rhythms of Rest (Downers Grove, IL: InterVarsity Press, 2005), 11.

${ }^{267}$ Ruth Haley Barton, Sacred Rhythms: Arranging Our Lives for Spiritual Transformation (Downers Grove, IL: InterVarsity Press, 2006), 142.

${ }^{268}$ Dorothy 'C. Bass, "Christian Formation for Sabbath Rest," Interpretation: A Journal of Bible and Theology (Richmond, VA: Union Presbyterian Seminary, January 2005), 25.

${ }^{269}$ Ibid., 37.

${ }^{270}$ Mark Buchanan, The Rest of God: Restoring Your Soul by Restoring Sabbath (Nashville: W Publishing Group, 2006), 2-3.
} 
Tilden Edwards connects Sabbath to ministry and speaks of their rhythm "as a foundational discipline for all disciplines that God provides to human life for its care, cleaning and opening to grace."271 "It is a time for "useless" poetry and other arts; a time to appreciate a tree, your neighbor, and yourself without doing something to them; a time to praise God as an end in itself. It is a time for superfluous - overflowing the merely necessary - movements, meetings, and words."272

Wayne Muller avers that the influence of Sabbath and Sabbathkeeping as a spiritual discipline is that "we harvest some of the sweetest fruits of life."

United Church of Christ area minister, retreat leader and writer Donna Schaper says "in sabbath we clean house. We declutter and start over, letting go of things that are urgent on behalf of things that are important. ${ }^{274}$

Norman Wirzba, professor of philosophy and chair of the department at Georgetown College in Georgetown, Kentucky, avows that the influence of the spiritual discipline of Sabbath and Sabbathkeeping is "that we participate regularly in the delight that marked God's own response to a creation wonderfully made."275

In her landmark treatment of Sabbath, theologian Marva Dawn unpacks four holistic influences of the spiritual discipline of Sabbath and Sabbathkeeping.

${ }^{271}$ Tilden Edwards, Sabbath Time (Nashville, TN: Upper Room Books, 2003), 168.

${ }^{272}$ Ibid.

${ }^{273}$ Wayne Muller, Sabbath: Finding Rest, Renewal, and Delight in Our Busy Lives (New York: Bantam Books, 2000), 102.

${ }^{274}$ Schaper, Sabbath Keeping, 38.

${ }^{275}$ Norma Wirzba, Living the Sabbath: Discovering the Rhythms of Rest and Delight (Grand Rapids, MI: Brazos Press, 2006), 15. 
Its Ceasing deepens our repentance for the many ways that we fail to trust God and try to create our own future. Its Resting strengthens our faith in the totality of his grace. Its Embracing invites us to take the truths of our faith and apply them practically in our values and lifestyles. Its Feasting heightens our sense of eschatological hope-the Joy of our present experience of God's love and its foretaste of the Joy to come. ${ }^{276}$

Don Postema, Professor of Philosophy at Bethel University, extends God's invitation to Sabbath rest in his "travel guide" entitled Catch Your Breath. He writes,

When I find a sabbath moment, hour, or day, it is like an island of calm in a hectic life. It is like a sigh of relief putting down a knapsack full of obligations, schedules, and deadlines. It is like an invitation to enjoy a vacation with my Divine Friend. It feels like being unshackled from whatever I am allowing to enslave me and getting a new perspective on life. ${ }^{277}$

\section{Seventh-day Adventist Christian Perspectives}

Volumes have been written by Seventh-day Adventist Christians on Sabbath and Sabbathkeeping, using many metaphors that reflect the influence of regarding it as a spiritual discipline.

In her delightful little book, Oh No, It's Sabbath Again and I'm Not Ready: A Homemaker's Guide to Making Friday the Easiest Day of the Week, Yarna Cerna Young begins with the recognition that preparation, practically and spiritually, is the key in Sabbath and Sabbathkeeping as a spiritual discipline.

Young points to the influence of Sabbath and Sabbathkeeping as a spiritual discipline on her young son who recognizes the signals of the oncoming of the Sabbath by her changing, not just the sheets and pillowcases on each bed each Friday, but by

\footnotetext{
${ }^{276}$ Marva J. Dawn, Keeping the Sabbath Wholly (Grand Rapids: Wm. B. Eerdmans, 1989), 203.

${ }^{277}$ Don Postema, Catch Your Breath: God's Invitation to Sabbath Rest (Grand Rapids, MI: CRC Publications, 1997), 64:
} 
changing the bedspreads on them as well to which he excitedly exclaims, "Yeeeah! It's Sabbath today!"278 The influence continues as the best meals of the week (featuring the favorite foods of the family) are served on the Sabbath, beginning on Friday evening in beautiful settings (table linens, best dinnerware, flowers, and candles) that make the Sabbath and Sabbathkeeping memorable and distinct.

Author Celeste Perrino Walker solicited traditions from around the world as the basis for her book, Adventist Family Traditions to Bless Your Heart and Home. A prevalent component that emerged from responses of many for whom Sabbath and Sabbathkeeping is a spiritual discipline is expressing gratitude and praise as many saw the Sabbath as a special opportunity not only to recount God's blessings in their lives during the preceding week but also to thank family members for kindnesses shown during that period of time as well. This included calls to parents and/or children who live in other places.

Millie and John Youngberg, professors emeriti of Andrews University, liken the influence of the spiritual discipline of Sabbath and Sabbathkeeping to both a birthday celebration and a wedding celebration. In memorializing creation on the Sabbath, humans are reminded that God is Creator which reminds us of our identity, purpose and value. But the wedding of Adam and Eve on the sixth day of Creation week was not the only celebration that day. "Then, a few hours later as the sun was setting, God celebrated another wedding-a wedding between humankind and God! The onset of sundown

\footnotetext{
${ }^{278}$ Yara Cerna Young, Oh No, It's Sabbath Again and I'm Not Ready: A Homemaker's Guide to Making Friday the Easiest Day of the Week (Boise, ID: Pacific Press, 1992), 87.
} 
signaled the Sabbath - that special time for the Creator and His beloved to be alone. Indeed, God set aside every weekly Sabbath for this ongoing love relationship. ${ }^{279}$

May-Ellen Colon, Assistant Director of the General Conference Sabbath School and Personal Ministries Departments, provides valuable insights on the influence of Sabbath and Sabbathkeeping as a spiritual discipline, beginning with the assertion that Sabbath is about a relationship with Christ. ${ }^{280}$ She uses the metaphor of a "vacation" for the Sabbath to which the principles of preparing (for this special day so we can joy its benefits); resting (from work, life's burdens, and secular concerns and distractions); renewing (physically, emotionally, mentally, spiritually, and socially); healing (fostering relief, release, liberation, and refreshment); and celebrating (the creation or birthday of the world and of our redemption) apply. ${ }^{281}$ But to vacation or Sabbath with God, the added principles of sanctifying (keeping the Sabbath holy, setting it apart for a special focus on God, His Word, and His agenda, to seek intimacy with Him, embrace Him wholly, and nurture a love relationship with Him that makes us holy); remembering (reflecting and rejoicing about the creation of the world, redemption from sin, and Christ's second coming and the creation of the new earth); worshiping (participating in corporate, focused worship of God with our church family); basking enjoying, studying, experiencing and basking in the world God made rather than working at maintaining it; responding (to God's grace in obedience to His loving command to remember Him and

\footnotetext{
${ }^{279}$ Millie and John Youngberg, Family Sabbath Traditions to Bless Your Heart and Home (Nampa, ID: Pacific Press, 2001), 23.

${ }^{280}$ May-Ellen Colon, From Sundown to Sundown: How to Keep the Sabbath ... and Enjoy It! (Nampa, ID: Pacific Press, 2008), 49.

${ }^{281}$ Ibid., 49-50.
} 
His Sabbath gift; and trusting (depending on God to take care of what we leave undone during the Sabbath hours) must be embraced. ${ }^{282}$ Finally, the principles of fellowshipping (nurturing our relationships with family and friends); affirming (rightly representing the atmosphere of the Sabbath by a spirit of acceptance and love rather than a spirit of judgment and criticism; serving (loving service to others and loving witness for God); and caring (not allowing any creature- - human or animal—-to suffer on this day) are introduced as requisites to vacation with God's family. ${ }^{283}$ Further these principles are substantiated as based on God's character.

Ellen White provides the ultimate perspective on the influence of Sabbath and Sabbathkeeping as a spiritual discipline when she refers to God's original intent.

God saw that a Sabbath was essential for man, even in Paradise. He needed to lay aside his own interests and pursuits for one day in seven, that he might more fully contemplate the works of God and meditate upon His power and goodness. He needed a Sabbath to remind him more vividly of God and to awaken gratitude because all that he enjoyed and possessed came from the beneficent hand of the Creator. $^{284}$

\section{Influence of Sabbathkeeping Spiritual Discipline on University Students}

No research was found on college and university students in the United States utilizing the spiritual discipline of Sabbathkeeping.

\footnotetext{
${ }^{282}$ Colon, From Sundown to Sundown, 50-51.

${ }^{283}$ Ibid., 51.

${ }^{284}$ Ellen G. White, "The Creation," in Patriarchs and Prophets (Mountain View, CA: Pacific Press, 1958), 48.
} 


\section{Influence of Sabbathkeeping Spiritual Discipline on African American Collegians}

No studies were found on African American collegians in the United States utilizing Sabbathkeeping as a spiritual discipline.

\section{Summary}

The spiritual formation of college and university students is much more a topic of interest now than it has been since the Enlightenment stressed human reasoning over faith and obedience. And studies regarding the role of higher education in the spiritual development are on the rise as well. It is clear, however, that far more research is needed, particularly with regard to the spiritual formation of African American students and the practice of Sabbathkeeping as a spiritual discipline among college and university students.

\section{Conclusion}

Unlike public colleges and universities that must always balance "church and state" issues, private liberal arts colleges, and especially religiously-affiliated institutions of higher learning have the great privilege and responsibility to examine the philosophical frameworks that dictate curriculum and co-curricular ethos and content. As emerging adults choose to matriculate at these institutions, they should be able to expect that consistent, coherent, and cogent opportunities for engaging in academic courses, servicelearning experiences, student organizations, faculty mentoring, and other campus-based activities are available to them for their holistic development with particular emphasis on their spiritual formation. 


\section{CHAPTER 4}

\section{METHODOLOGY AND IMPLEMENTATION NARRATIVE}

\section{Introduction}

Much has been published in recent years on the topics of spiritual formation, spiritual disciplines and Sabbath/Sabbathkeeping as the perception of their importance appears to be growing but there are areas that remain to be examined. The literature reveals a broad diversity of thought and practice. Because there is a paucity of literature addressing spiritual formation and spiritual discipline as experienced in different cultural contexts or in specific age categories, this research seeks to discover the influence of a spiritual formation course on the perspectives of African American Oakwood University students on Sabbath and Sabbathkeeping as a spiritual discipline.

Richard Osmer states in his book Practical Theology: An Introduction, that "practical theological interpretation involves four key tasks: the descriptive-empirical, the interpretive, the normative, and the pragmatic."1 And this chapter which has the Pragmatic Task of the Pastoral Cycle to provide Pastoral Action will "determine strategies of action that will influence situations in ways that are desirable and enter into a reflective conversation with the 'talk back' emerging when they are enacted." $\mathrm{We}$

\footnotetext{
${ }^{1}$ Osmer, Practical Theology, 10.

${ }^{2}$ Ibid., 4.
} 
therefore proceed to cover the ministry context, the research methodology, the intervention, the implementation narrative and the conclusion.

\section{Ministry Context}

\section{Origins}

Ellen G. White, who co-founded the Seventh-day Adventist Church and played an integral part in establishing of Oakwood University, wrote much on the subject of Christian education that has informed the purpose and philosophy of Oakwood and all other Seventh-day Adventist schools since their inception. She advocated a holistic concept of education that transcended temporal considerations.

Our ideas of education take too narrow and too low a range. There is need of a broader scope, a higher aim. True education means more than the pursual of a certain course of study. It means more than a preparation for the life that now is. It has to do with the whole being, and with the whole period of existence possible to man. It is the harmonious development of the physical, the mental, and the spiritual powers. It prepares the student for the joy of service in this world and for the higher joy of wider service in the world to come.

\section{Oakwood University}

Accredited by the Adventist Accrediting Association of the Department of Education of the General Conference of Seventh-day Adventists and the Southern Association of Colleges and Schools, the operation of Oakwood University is governed by the "Seventh-day Adventist Philosophy of Education" as enunciated in the General Conference Policy Manual. Stated in part, "the distinctive characteristics of Adventist education-derived from the Bible and the writings of Ellen G. White point to the

\footnotetext{
${ }^{3}$ Ellen G. White, "The Source and Aim of True Education," in Education, hitp://www.ellenwhite .org/sl/ed01.htm (accessed September 4, 2009).
} 
redemptive aim of true education: to restore human beings into the image of their Maker." The Policy Manual states that "the Seventh-day Adventist Church has made a commitment to provide a broad education and spiritual formation for its children, youth, and young adults within the context of the Christian worldview."

Oakwood University is one of over 100 historically black colleges and universities (HBCUs) in the United States. According to the United Negro College Fund of which Oakwood University is a member, HBCUs are "one of the surest ways for an African American, or a student of any race, to receive a high quality education."\% In "A Message From the President" found on page 3 of Oakwood's bulletin, Dr. Delbert W. Baker (who served in that capacity from 1996 to 2010) addresses prospective students with these words: "During your time here, if you make a commitment to its aim, Education, Excellence, Eternity, and its motto, Enter to Learn, Depart to Serve, Oakwood ... promises to be one of your most rewarding experiences."7 Preparation "for the joy of service in this world" ${ }^{\prime 8}$ is very evident in Oakwood alumni such as Linda L. Ammons, Dean of the Widener School of Law and Barry C. Black, Chaplain of the United States Senate.

\footnotetext{
4"Seventh-day Adventist Philosophy of Education," in General Conference Policy Manual (2003), Education-Departmental Policies: FE05, FE10, http://circle.adventist.org/download/PhilStat2003.pdf (accessed September 3, 2009).

${ }^{5}$ Ibid.

${ }^{6} \mathrm{HBCU}$, http://www.uncf.org/aboutus/hbcus.asp (accessed July 5, 2009).

${ }^{7}$ Oakwood University, Oakwood University Bulletin 2007-2009, 3.

${ }^{8}$ White, Education.
} 


\section{Department of Religion and Theology}

Additionally, President Baker states that "at Oakwood your spiritual development is a vital concern." As such the department of instruction most immediately and obviously charged with responding to that concern is Religion and Theology.

The purpose of the educational program of the Department of Religion and Theology is to provide Christ-centered, distinctively Seventh-day Adventist, clinically grounded theological education for students in preparation for pastoral ministry, evangelism, teaching, Christian counseling, and chaplaincy. The programs are designed to prepare individuals for effective service to God, church and humanity. Specifically the program seeks to prepare students for entry-level practice in ministry and for seminary and graduate study in religion and theology in preparation for specialized ministry. ... The department serves the general student body of Oakwood University through the provision of religion and theology courses across the curriculum. The department also serves as a resource to all university departments for the promotion of faith and learning. ${ }^{10}$

The curriculum of the Department of Religion and Theology at Oakwood University is organized around three core concepts: Christ-centeredness, Scripture, and ministry. Integrating themes for program methodology include holistic education, the integration of faith and learning, and service learning. "

\section{RP131: Spiritual Formation for Ministry}

The foundational course for all theology majors is RP131: Spiritual Formation for Ministry and it is offered both Semesters. Because it is a freshmen level course, many of the students who enroll in this class are not theology majors but select it as an elective to fulfill the 11-12 credit hour requirement of courses from the Department of Religion and Theology for all graduates of Oakwood.

The course description appears in the departmental student handbook as follows:

${ }^{9}$ Oakwood University, Oakwood University, 3.

${ }^{10}$ Oakwood University Department of Religion and Theology, Oakwood University Department of Religion and Theology Student Handbook 2009-2009 (Huntsville, AL: Oakwood University, 2008), 9.

${ }^{11}$ Ibid., 11. 
A biblical, theological, historical and practical course of spiritual formation for Christian ministry. Students examine and engage in the spiritual disciplines foundational to a strong devotional life and Christian service. Emphasis is given to the relationship between personal, corporate and social spirituality, particularly the role of a spiritual guide in the development of spiritual formation in others. Laboratory work is required. ${ }^{12}$

Two sections of this course were offered by the Department of Religion and Theology at Oakwood University during Spring Semester 2009 (January 14-April 22). Each section met on Mondays and Wednesdays for 50 minutes (9:00-9:50 a.m. and 10:00-10:50 a.m.) in one of the classrooms of the Moseley Complex which houses the Department of Religion and Theology, although some course assignments (e.g., synagogue worship and the weekend retreat) required off-campus experiences.

The demographics of the student population suggested a rich diversity of age, gender, academic majors, and classifications as well as Adventist backgrounds. Of the 40 students originally enrolled in the two sections, 14 were female and 26 were male. Twenty-four of the students were theology majors and 16 identified other majors. Nineteen were freshmen; 12 were sophomores; 5 were juniors; 3 were seniors; and 1 was a graduate student pursuing the Master of Arts in Pastoral Studies degree. Twenty-eight were between the ages of $18-21$ and 12 were over 21 years of age. Twenty-seven were born into Seventh-day Adventist families; 5 had been Seventh-day Adventists 1-5 years; and 8 had been Seventh-day Adventists over 5 years. However, only 34 of the 40 students completed both the Pre- and the Post-Test; therefore, the research sample number of students is 34 .

\footnotetext{
${ }^{12}$ Oakwood University Department of Religion and Theology Student Handbook 2009-2009, 29.
} 


\section{Research Methodology \\ Description of Research Methodology}

The methodology employed in this study was action research which is "a process of systematic inquiry, usually cyclical, conducted by those inside a community rather than outside experts; its goal is to identify action that will generate some improvements believed to be important." 13

On the first and last days of the Semester, students enrolled in RP131: Spiritual Formation for Ministry completed a Pre- and a Post-Test. The survey, which was used for both the Pre- and Post-Test, was formulated to uncover what students knew about Sabbath and Sabbathkeeping (cognitive); what students did and/or refrained from doing on Sabbath (kinesthetic/behavioral); and how students felt about Sabbath and Sabbathkeeping (affective).

The survey was designed to obtain both quantitative and qualitative data. Combining methods in this single study added to the scope and breadth of the study. The methods were also complementary in that overlapping and different facts of some phenomena could emerge. The survey instrument used in this research (located in appendix A) is referenced as Pre-Test/Post-Test. The quantitative survey included openended questions. In addition to the survey, other types of qualitative data gathered included the student retreat evaluations, resource files, and reflection papers.

\section{Interpretation of Data}

Mixed methods were utilized in this research as a "strategy to enhance the rigor,

\footnotetext{
${ }^{13}$ Patricia H. Hinchey, Action Research Primer (New York: Peter Lang Publishing, 2008), 4.
} 
breadth, complexity, richness and depth of this inquiry." 14 I used SPSS to analyze the quantitative data of the survey instrument. Inputting data from the "Pre-Test" and the "Post-Test" in format allowed for analysis using the Paired Sample BiT-Test. Analysis was conducted to calculate the mean values of the five clusters. It was then possible to use the Paired Sample T-Test to evaluate the "Pre-Test" and "Post-Test" means to determine if there was a significant difference at the .05 level.

Patterns, trends, and meanings that emerged from the qualitative data of the survey instrument determined the themes that resulted.

\section{Intervention}

The course included both classroom/homework learning experiences and practicum learning experiences. Classroom/homework learning experiences emphasized weekly reading reports to demonstrate an appropriate grasp of the assigned reading; weekly practice of a rule of life and the spiritual disciplines; lecture/discussions; resource files and reflection papers. The practicum learning experiences required participation in covenant group assignments, synagogue worship, and the weekend retreat.

The rationale for this course content is twofold. It is based on the integrating themes of the Department of Religion and Theology which are holistic education, the integration of faith and learning, and service learning. It is also predicated on the specific course objectives/learning outcomes as articulated in the course syllabus.

At the conclusion of this course, the student will be able to:

1. Describe the biblical, theological and historical foundations of spiritual formation.

2. Discuss the Christological basis for spiritual formation.

\footnotetext{
${ }^{14} \mathrm{~J}$ ohn Swinton and Harriet Mowat, Practical Theology and Qualitative Research (London, England: SCM Press, 2006), 51.
} 
3. Describe the spiritual disciplines of the Christian devotional life.

4. Recognize the relationship between personal, corporate and social spirituality.

5. Understand the role of a spiritual guide in the formation of others.

6. Practice the spiritual disciplines and Christian service.

7. Accept the formative role of the Word in developing personal, corporate and social spirituality.

8. Identify resources for continuing spiritual formation. ${ }^{15}$

Because this course is intended to be transformational as well as informational, it was necessary to require the students not only to read the literature relating to the process of being conformed to the image of Christ for the sake others and the means by which that is fostered, but to engage in a daily discipline that was based on a weekly rule of life as well.

Accountability in the dynamic of small group activities was a key formational component and each student also had to identify resources for continuing spiritual formation to be employed beyond the limits of the course. Some of the activities took place outside of the classroom, such as group fasts, service learning projects, and designing corporate worship experiences. Covenant groups were also responsible for preparing and presenting the themes of assigned devotional material at the start of class.

Course requirements also specify that each'student must prepare a resource file that takes the place of a final examination. Its purpose is to equip the students to identify continuing resources for spiritual formation beyond the limits of the course. And on the final day of instruction, reflection papers were submitted as a means of spiritual selfinventory.

${ }^{15}$ Oakwood University Department of Religion and Theology Student Handbook 2008-2009, 29. 


\section{Implementation Narrative}

Course Description

On the first day of the course (January 14), a PowerPoint slide was on the screen as students entered the classroom that welcomed them, identified the course about to commence, identified myself as the instructor and asked them to pick up a folder, an index card, a copy of the syllabus, a copy of the Keirsey-Bates Temperament Inventory, and a copy of the "Informed Consent Letter" that were on the counter. The slide also instructed them to read the "Informed Consent Letter" after personalizing their folders and index cards.

When it was time for class to begin, I introduced myself, welcomed the students, and proceeded with a devotional reading from the book He Shall Be Called: 150 Names of Jesus and What They Mean to You by Robert J. Morgan and prayer. The research project was then explained as well as the need for the surveys and the "Informed Consent Letter" (Letter). I asked everyone eighteen years of age and older who was willing to participate to sign the Letter. The students were assured that on the occasion of our next class, each of them would receive a copy of her or his signed Letter.

With the exception of one student who was not yet eighteen years old and one who was not African American, everyone chose to participate, sign the letter, and complete the survey. In the time that remained after the completed surveys had been submitted, the students then introduced themselves, and I explained the homework assignment of completing of Keirsey-Bates Temperament Inventory for the next class period because the results were to be used in forming the covenant groups. I then collected the folders and explained that each class period the students would be able to 
retrieve their graded assignments in their folders that would be in a rolling file cart at the front of the classroom because class time would not be used for distribution. The students were asked either to take the index cards with them and return with them for subsequent class periods until I learned their names or to put them inside their folders to be retrieved upon entering the classroom each time.

When the students entered the classroom on the second day of class (January 21-there was no class on January 19 as the birthday of Martin Luther King's birthday was observed), a PowerPoint slide was on the screen instructing the students to place their homework assignments on the counter; to pick up the handouts from the counter which included (1) the "Rule of Life," (2) the report form for the weekly practice of the spiritual disciplines, (3) the report form for the weekly reading assignments, and (4) Covenant Group Guidelines; and to place their name cards on the desks after they were seated. At the scheduled time the class period began with a reading from the aforementioned book and prayer. In the remaining time the syllabus and the handouts were discussed. The students were not only reminded to check their folders into which their copies of the "Informed Consent Letter" had been placed, but to follow the "Course Calendar" in the syllabus by reading the first four chapters in Invitation to a Journey: A Road Map for Spiritual Formation by M. Robert Mulholland Jr. and the first chapter in Celebration of Discipline: The Path to Spiritual Growth by Richard J. Foster.

The PowerPoint slide of the screen the third day of class (January 26) asked the students to place their homework assignments (weekly reading report and weekly report of the rule of life and practice of the spiritual disciplines) on the counter before the start of class and to pick up a copy of the handouts entitled "Covenant Group Designations, 
Assignments and Calendar" and the "Rubric for Devotional Presentations." Class began with time for meditation on Scripture and prayer.

Discussion of the handouts followed regarding the directive that a covenant group would be responsible for the devotional presentation every Wednesday and the source materials for the presentations were Steps to Christ by Ellen G. White and $A$ Gardener Looks at the Fruit of the Spirit by W. Phillip Keller. Each covenant group was assigned two dates during the Semester for a devotional presentation. The students were encouraged to be creative and to use the rubric in preparing the presentation. Throughout the Semester an interesting variety of options was used for this assignment including talk show formats, game show formats, homemade movies, skits, original art, quizzes, and more.

The first lecture/discussion also took place on the third day of the course as the class examined the definitions and explanations given by the authors of their reading assignment for spiritual formation and the necessity of discipline. The structure of the course was then set for Mondays to be used for the initial interaction with the authors and Wednesdays to be the occasion for further inquiry and exploration after the covenant' group devotional presentation.

One month into the Semester (February 27) the students were required to attend one of two local synagogues for Shabbat evening worship. By that time the students had been introduced to spiritual disciplines of prayer, meditation, fasting, and study theoretically, through assigned readings, and experientially, through homework assignments. On the Wednesday prior to the Shabbat eve worship experience, the students were given a packet of handouts for their next reading assignment: (1) from The 
Sabbath: Its Meaning for Modern Man by Abraham Joshua Heschel, the prologue, "Architecture of Time," chapter 1, "A Palace in Time," and chapter 9, "Holiness in Time;" (2) from A Love Song for the Sabbath by Richard M. Davidson, chapter 1, "Psalm 92 - A Love Song for the Sabbath," and chapter 7, "A Psalm of Life;" and (3) from Keeping the Sabbath Wholly by Marva J. Dawn, the preface and chapter 28, "Sabbath Ceasing, Resting, Embracing, and Feasting."

The handouts were the bases of the lectures and discussions, on the Monday and Wednesday that were immediately followed by the retreat, as the class focused on these three perspectives/interpretations of the Sabbath and Sabbathkeeping. On Wednesday, the students played a version of the game "Scattergories" that required each student to write down as many Sabbathkeeping activities they could think of within 30 seconds. They were told that the winner would be the one with the most points, but a point could only be earned by having an answer no one else had written down. Each student had the opportunity to share the activities from her/his list with the rest of the class. In the end all the activities identified by the students were on the board, winners were identified, and I then shared the principles developed by Gregory Allen for determining appropriate Sabbathkeeping activity as follows:

Principle 1: Is the deed in question a vice? (See Rom. 1:24-32; 1 Cor. 5:19-21; Gal. 5:19-21) Principle 2: Is the action appropriate to our measure of faith? (See Rom. 12:3; cf. Rom. 4:20; 1 Cor. 12:9; Rom. 12:6) Principle 3: Do we as individuals have doubts about its appropriateness? (See Rom. 14:14, 23) Principle 4: Are we as individuals fully convinced that an action is proper for us? (See Rom. 14:5, 14; cf. Phil. 1:25) Principle 5: Does the behavior give expression to love for the others in the community? (See 2 Cor. 5:14; cf. 1 Cor. 8:1) Principle 6: Does the action glorify God in Christ, give thanks, and anticipate Christ's second coming? (See 1 Cor. 31-33; Rom. $1: 21 ; 15: 5,6){ }^{16}$ 23-25.

${ }^{16}$ Gregory J. Allen, “How Shall I 'Keep' the Sabbath Holy?” Adventist Review, August 29, 1996, 
Retreat Description

The retreat was held on March 13-15, the first weekend following Spring Break. It was held at Camp Sumatanga, a camp and conference center owned and operated by the United Methodist Church. Chaperonage and theme presentations during plenary sessions were provided by faculty from the departments of Communications, Nursing, and Religion \& Theology. Because the site is located 85 miles south of Huntsville, transportation was provided by the university busses which allowed the corporate retreat experience to extend to travel time. Upon arrival at Camp Sumatanga on Friday evening, folders were distributed, room assignments were made, directions were given, and everyone was allowed time to settle into their living spaces before dinner. With the exception of sleeping and dining quarters, all of the activities for the entire group took place in the main auditorium of the lodge.

"Praise and Worship" teams formed spontaneously and led out with songs, testimonies, and skits for the first forty-five minutes of each session. On Friday night sentence prayers of adoration, offered randomly as the Spirit moved among the participants, followed the time of praise and worship. "The Name Game" served as formative fellowship after prayer so that everyone had an enjoyable way of meeting and interacting with everyone else. "Perusing the Past" was the theme for evening and everyone was asked to find a place of silence and solitude in which to read and journal responses to reflection questions on Isaiah 49:1-7 for 45 minutes. The silence was broken when the covenant groups convened to discuss their responses to the reflection questions for 45 minutes. The faculty in attendance became a covenant group for the weekend as well as participated in all activities. Then, for the last 15 minutes before 
"Free Time," the entire group gathered for a plenary session during which time Dr. Gregory Allen from the Religion and Theology Department invited the students to share their discoveries and then offered provocative insights to the text before closing with prayer. During "Free Time" Bible videos and Bible games were available for student use.

After breakfast on Sabbath morning, an hour of "Free Time" was provided so that the beautiful natural surroundings could be enjoyed. At the end of "Praise and Worship," everyone was invited to select two pictures from a large selection of photographs spread across tables in the back of the auditorium. The selection was to be based on each person's childhood image of God and her/his current image of God. After the pictures were chosen, the students gathered in their covenant groups to discuss the reasons for the selections that were made and the journey between the two images. Each person was then to pray a prayer for thanksgiving for the person on the right to close out that session before engaging the theme, "Pondering the Present." Again everyone was asked to find a place of silence and solitude in which to read and journal responses to reflection questions on Psalm 139:1-24 for 45 minutes. The silence was broken again when small randomly formed groups convened to discuss their responses to the reflection questions for 45 minutes. Then, for the last 15 minutes before lunch the entire group gathered for plenary session during which time Dr. Carol Allen of the Nursing Department invited the students to share their thoughts and then offered helpful applications of the text before closing with prayer.

After lunch free time to climb the mountain to the cross, hike the trail around the lake, play a game, watch a video, chat with friends, or take a nap was available to all 
before the afternoon session began. As before our time together commenced with praise and worship which was interspersed with original poetry and rap as well as instrumental selections. The five movements of Enacted Prayer were taught to the students who were given the opportunity to practice it and share their reactions to this form of prayer that was unfamiliar to them. Bridging into the afternoon theme, "Savoring the Sabbath," the song "Shabbat Shalom" was taught to the students in Hebrew who sang it enthusiastically. Then, as before, everyone was asked to find a place of silence and solitude in which to read and journal responses to reflection questions on Psalm 92 for $\mathbf{4 5}$ minutes. Once again the silence was broken when new small randomly formed groups convened to discuss their responses to the reflection questions for 45 minutes. Then, for the last 15 minutes before dinner, the entire group gathered for plenary session that I led, during which time the students were invited to share their musings. They offered thought-provoking perspectives on the text before closing with prayer.

An hour of "Free Time" after dinner provided time for the faculty to prepare for the candlelight communion service that followed. Rectangular tables formed a cross and chairs were positioned so that each participant could be seated at the cross. The cross was covered with white linens and on it were placed two gold chargers. One held pita bread and the other a chalice of grape juice. At the foot of the cross stood a cross that was draped with a narrow crimson scarf and flanked by baskets of pencils, paper, and push pins. Two side tables were also draped and adorned with candles. Paper towels, hand sanitizers, and pitchers of warm water were also on these tables that stood between foot-washing basins on one side and empty buckets on the other.

Following an exegesis of 1 Corinthians 11:17-26 by Dr. Gregory Allen, everyone 
was invited to participate in the Ordinance of Humility at the cross while recorded instrumental music played softly in the background. Once this period of preparation was completed, each person then served the person to her/his right with the bread and the juice, saying, "This is the body of Jesus, broken just for you, . And this is the blood of Jesus, poured out just for you, ___ " while the recorded music continued.

After everyone had partaken of the bread and the juice, the invitation was extended for prayers of confession to be written anonymously on slips of paper in the basket at the foot of the cross, folded, and then pinned to the cross. When all the prayers were affixed to the cross, it was carried to the fireplace just outside the auditorium and there all the sins confessed on those papers were removed from the cross and thrown into the fireplace where they were burned up, representing victory over sin. For the rest of the evening all were free to socialize, sleep, or study.

The last occasion for the Praise and Worship teams to serve followed breakfast and the final opportunity for "Free Time." Then prayers of petition were written to God and placed in envelopes that each person self-addressed. They were collected to be sent on the same date one year later so that each person could remember the context of the prayer request and rejoice in God's response. "Facing the Future" formed the theme for Sunday morning and everyone again found a place of solitude and silence in which to read and journal responses to reflection questions on Isaiah 55 for 45 minutes. This time when the silence was broken again covenant groups convened to discuss their responses to the reflection questions for 45 minutes. And for plenary session, Dr. Janice Watson from the Communications Department invited the students to share their reflections and then offered practical means of living the text before closing with prayer. 
Just before lunch the entire group formed a large circle with our lighted candles and sang, "This Little of Mine" and a packet of Sabbath cards, created by Dionne Lynch Finney of It's All in the Rest, was given to each person as a memento of the weekend retreat. Once lunch was over the bus returned the group to the Oakwood University campus.

The rest of the Semester seemed qualitatively different as a result of the retreat in terms of appreciation, not only of the Sabbath and Sabbathkeeping, but of spiritual formation and the spiritual disciplines in general. Perceptible changes in attendance, attentiveness, preparedness, and participation were noted in many of the students. According to the evaluations, the most helpful aspect of the retreat was the Communion service (25) followed by the fellowship and climb to the mountain top (10 each).

The rating of "Very Helpful" was assigned to the following categories by the number of students noted: (1) The retreat an important part of the Oakwood University experience [ 43 students]; (2) the retreat as spiritually beneficial [ 37 students]; (3) meditation on the Scripture beneficial [40 students]; (4) Time in silence and solitude beneficial [35 students]; (5) Playing formative fellowship games beneficial [34 students]; (6) Small group time beneficial [ 35 students]; and the Communion experience beneficial [36 students].

As the students presented their resource files to the class at the end of the Semester, the reality of corporate spirituality was easily recognized as more ideas for growth were shared than could have been apprehended individually. They were encouraged throughout the Semester to be working on this project through the lens of their own temperaments and personal histories, using tangible expressions of the 
identified resources. A typewritten paragraph explaining each of the resources, the history of their significance, relevance, and application accompanied each resource.

A non-theology major male student identified the retreat as a category in his spiritual formation resource file and explained its inclusion as follows:

"Camp Sumatanga was the name of place where my eyes saw my true characterthe place where some of the closest friendship that I will ever have in life were formed the place where my test started. It was there that I found the true meaning of separation and solitude. I learned about God's plan in my past, my present, and also in my future. And if that wasn't enough, I found out that my view of the Sabbath was far off the path where it should have been. Talk about growing from a boy to a man in God. I had true formation during communion. It's funny how when I was younger, and when I got baptized for that matter, I never got the true meaning of something so special. I thanked God for Dr. Kwesi's talent in man oh man what a blessing. A true mountain top experience is what I had that weekend."17

And a non-theology major female student admitted,

“Growing up I always felt that his 'Sabbath' was a burden, a time when you can't do anything but entertain yourself by placing God in front of it. This mindset carried over till my teenage years and then I attended the Spiritual Formation Retreat. From the moment we entered that chapel and Sabbath cards, I knew this was going to be a special experience. I didn't even know Sabbath cards existed. I felt like a child, curious about this new approach to Sabbath."18

\footnotetext{
${ }^{17}$ Appendix D, 249-250.

${ }^{18}$ Ibid., 254-255
} 
On the last day of the course, the students submitted their two-to-three page typewritten reflection papers that synthesized their semester-long spiritual experience by answering three questions: (1) In what ways have you grown spiritually? (2) What have you learned about yourself? (3) What have you learned about God? Introspection is an essential aspect of growth for all areas of life, particularly in the spiritual realm. This exiting strategy also provided closure for the course in a meaningful manner.

Excerpts from the reflection papers on the spiritual retreat also help to explain the qualitative difference in the students after the retreat. A male theology major wrote, "When we left Oakwood, I didn't want to go on the trip. When it was time to go, I didn't want to leave the camp grounds. Most people didn't want to leave because they didn't want to return to work. I didn't want to leave because I spent the best Sabbath of my life there and more importantly, I spent it with God."19

A female non-theology major indicated that "At the retreat, Dr. Carol Allen told us to picture God as eternity high and wide and then to view time as a slip of paper with our stories on that paper. In my mind my stories were a dot on the paper. Then she said that on the Sabbath God confines Himself to that dot so that He can take care of our issues. When I heard that, it literally blew my mind; it was a fresh and new concept that included freedom and joy in Christ. It turned my mindset from wishing Sabbath was over to being anxious for the Sabbath to come to I can experience that intimacy. $" 20$

"The thing that blew my mind was when we were on the retreat and Dr. Allen said the first gift God gave us was the Sabbath," reported a female theology major. She

\footnotetext{
${ }^{19}$ Appendix C, 225.

${ }^{20}$ Ibid., 227-228.
} 
continued, "The day after man was created God designed it so that we rest [because] He never wanted us to work on that day. Now I understand why it says in Mark 2:27, 'The Sabbath was made for man, not man for the Sabbath.' I've also come to the understanding that praise, worship and adoration are all gifts from God for us to give back to Him. I'm still trying to wrap my mind around all of that. What I've learned about God is that He is just amazing. It's hurting my brain to find a word in the English language that can ever come close to relay how amazing this God I serve is."21

A male theology major shared, "I have learned more at this Sumatanga mountain experience then in the last that I went to last semester, [although I'm] not saying that there was no effort [from] last year's retreat. The experience this year, in a way, had more meaning. I truly felt that the Sabbath experience was like none other that I've experienced. It changed my perspective of . . . a 'good Sabbath' and a 'God-centered, great Sabbath.' The song 'How good it is to thank the Lord' touched me not only in words but in tune. I felt a sobered sense of calm at the last supper this time around than I did the last time."22

"My take on the Sabbath has completely changed ever since the spiritual retreat," stated another male theology major. "It has truly become the place where I realize all the provisions that God had made just to spend some time with me." ${ }^{, 23} \mathrm{He}$ adds, "At the spiritual retreat I [was] thoroughly blessed by hearing the testimonies and the experiences of my Quad Pod members [small group] which empowered me and encouraged me with

\footnotetext{
${ }^{21}$ Appendix C, 230-231.

${ }^{22}$ Ibid., 232-233.

${ }^{23}$ Ibid., 235.
} 
the fact that Jesus can really change hearts from any road of life."24

A non-theology major declared that "what came to my attention that's so beautiful to me about my Lord is that He steps out of eternity for a day to get closer to me; Sabbath is not a day but a person." 25

"Experiencing the Spiritual Retreat taught me that I should never place God inside of a box," offered a male theology major. Continuing he notes, "I became to accustomed to Sabbath worship in the sanctuary, it blew my mind the way we communed with Him so intimately on the retreat." 26

A non-theology major male student who began the semester contemplating a career in professional basketball disclosed his epiphany that like people who get married out of obligation and not love because they are expecting a child, "I realized that I could not give up Sabbath for the Sabbath in that manner. It had to be something I love. Thus, I would be giving up something I love for something I love more."27

The final task of the students was to complete and submit the Post-Test so that a comparison might be made of any shifts that occurred during the Semester. My role in all of the intervention was not just that of professor, but that of facilitator and companion on the journey as well.

\section{Conclusion}

To reiterate the ministry context for this research endeavor was the course RP131:

\footnotetext{
${ }^{24}$ Appendix C, 236.

${ }^{25}$ Ibid., 238.

${ }^{26}$ Ibid., 241.

${ }^{27}$ Ibid., 243.
} 
Spiritual Formation for Ministry offered by the Department of Religion and Theology during Spring Semester 2009 at Oakwood University. The purpose of the study was to discern the influence of this course on the perspectives of African American Oakwood University students on Sabbath and Sabbathkeeping as a spiritual discipline. The research methodology of this project was a combination of qualitative and quantitative methods.

On the first and last days of the semester, students enrolled in RP131: Spiritual Formation for Ministry completed a Pre- and a Post-Test. The Pre-, Post-Test survey was formulated to find what students knew about Sabbath and Sabbathkeeping (cognitive); what students did and/or refrained from doing on Sabbath (kinesthetic/behavioral); and how students felt about Sabbath and Sabbathkeeping (affective).

The research intervention included covenant group assignments, lectures/ discussions, weekly reading assignments and reports, weekly practice of the rule of life and the spiritual disciplines, homework, synagogue worship, weekend retreat, resource files, and reflection papers.

The Post-Tests were intended to reveal any shifts or patterns of change in the perspectives of the students who were enrolled during Spring Semester 2009 in RP131: Spiritual Formation for Ministry.

Further research and reflection are clearly warranted with regard to methodologies that "focus on goals and actions that can be undertaken to shape events toward desired goals as researchers seek to respond in ways that are faithful and effective." 28

In the next chapter, outcomes and evaluation are presented.

${ }^{28}$ Osmer, Practical Theology, 10. 


\section{CHAPTER 5}

\section{OUTCOMES AND EVALUATION}

\section{Introduction}

This research project seeks to determine the influence of a spiritual formation course on the perspectives of African American Oakwood University students on Sabbath and Sabbathkeeping as a spiritual discipline. The Pastoral Cycle of Richard Osmer's theoretical framework for this project has returned to the Descriptive-Empirical Task. Chapter 5 is therefore, once again, focused on what is happening but additionally, it reveals the outcomes of the research, evaluates the intervention, interprets the data and draws conclusions from the data. Outcomes of the intervention are examined that are clearly measurable by the research methodology employed. The chapter ends with a summary that reiterates the main points, conclusions that explain the findings, and recommendations that state what should be done, acknowledging directions for further research and reflection.

\section{Description of Research Methodology}

As stated in chapter 4, the methodology employed in this study was action research which is "a process of systematic inquiry, usually cyclical, conducted by those inside a community rather than outside experts; its goal is to identify action that will 
generate some improvements the researcher believes important." 1

John Swinton and Harriet Mowat contend that "Practical Theology is

fundamentally action research." ${ }^{2}$ Although they agree that action research methodology

in Practical Theology is similar to those of the social sciences, they argue that Practical

Theology has a more compelling goal. They distinguish the two as follows:

In the social sciences the term 'action research' relates to a family of research methods which find their primary focus in the utilization of the research process not simply as a way of gaining new knowledge, but also as a way of enabling new and transformative modes of action. ${ }^{3}$

The practical theological action always has the goal of interacting with situations and challenging practices in order that individuals and communities can be enabled to remain faithful to God and to participate faithfully in God's continuing mission to the world. $^{4}$

On the first and last days of the semester, students enrolled in RP131: Spiritual Formation for Ministry completed a Pre- and a Post-Test, both of which used the same survey. The survey was formulated to uncover what students knew about Sabbath and Sabbathkeeping (cognitive); what students did and/or refrained from doing on Sabbath (kinesthetic/behavioral); and how students felt about Sabbath and Sabbathkeeping . (affective).

The survey was designed to obtain quantitative and qualitative data. The purpose for combining methods in this single study was expansion to add to the scope and breadth of the study. The complementary nature of the survey allowed for overlapping of some

\footnotetext{
${ }^{1}$ Hinchey, Action Research Primer, 4.

${ }^{2}$ Swinton and Mowat, Practical Theology and Qualitative Research, 255.

${ }^{3}$ Ibid.

${ }^{4}$ Ibid., 257.
} 
phenomena. The survey instrument used in this research (located in appendix A) is referenced as Pre-Test/Post-Test. In addition to the survey, other types of qualitative data gathered included the student retreat evaluations, resource files, and reflection papers.

The Pre-Test/Post-Test instrument contains 36 items that quantify the personal spiritual and theological foundations of the students relative to Sabbath and Sabbathkeeping. The order of the items is random and some items are phrased positively while others are presented negatively.

The survey includes five open-ended questions that seek to understand the reasons for the quantifiable data so as to arrive at a more complete and holistic understanding of the quantitative findings.

The order of interpretation will be that the quantitative data will be addressed first followed by the interpretation of the five open-ended questions that comprise the quantitative component of the survey. Explanations of the procedures and my expectations will be included in the narratives.

\section{Outcomes}

Interpretation of Quantitative Data

The first stem question on the survey instrument used for the Pre- and Post-Test asked, "Which statement(s) best describe your understanding of Sabbath?" and each item in table 1 was then listed. The Pre- and Post-Test differences in the students' understanding of Sabbath are shown in table 1. 
Table 1. Differences in pre- and post-test means for understanding Sabbath

\begin{tabular}{|l|c|c|c|c|c|}
\hline Item & Pre-T Mean & SD & Post-T Mean & SD & Difference \\
\hline Burden * & 4.32 & 1.15 & 4.87 & .41 & .55 \\
\hline Any time of rest * & 4.15 & 1.23 & 3.66 & 1.69 & -.49 \\
\hline Delight & 4.50 & .90 & 4.97 & .17 & .47 \\
\hline Good news & 4.47 & .90 & 4.88 & .41 & .41 \\
\hline Commandment to be obeyed ** & 4.91 & .29 & 4.64 & .74 & -.27 \\
\hline Seventh day of the week & 4.67 & 1.01 & 4.93 & .24 & -.26 \\
\hline Way of life & & & & .71 & .25 \\
\hline Sealing for salvation & 4.32 & .91 & 4.57 & 1.33 & .11 \\
\hline Spiritual discipline & 3.44 & 1.40 & 3.55 & 1.33 \\
\hline First day of the week * & 5.00 & .00 & 5.00 & .00 & .00 \\
\hline
\end{tabular}

5-point scale with $1=$ Strongly Disagree, $5=$ Strongly Agree; $\mathrm{N}=34$

* Reverse scoring indicated (Reverse items: $1=$ Strongly Agree and $5=$ Strongly Disagree)

** Subtleties explained in the text

Table 1 gives evidence of great change in the students' understanding of Sabbath as not being "a burden." The students indicated moderate change in their understanding of Sabbath in the areas of regarding Sabbath as a "delight" and "good news" as well as not being "any time of rest." This table also notes small changes in the students' understanding of Sabbath as not just a "commandment to be obeyed," but as the "seventh day of the week," a "way of life," "sealing for salvation" and as a "spiritual discipline." There was no change in the student's understanding of the Sabbath as not being on the "first day of the week."

I compared the student responses of the Pre-Tests with those of the Post-Tests and 
looked for changes or shifts in understanding or perspectives. The Pre-Test mean was subtracted from the Post-Test mean to arrive at the mean change or difference.

The asterisked items in table 1 were reverse-scored. By the end of the course, students who initially viewed Sabbath as a "burden" significantly changed their perspectives positively as did the number of students who understood the Sabbath as a "delight" and "good news." The change from not considering the Sabbath as "any time of rest" to considering a Sabbath to be "any time of rest" was an item of significant positive change.

Because all of the students were Seventh-day Adventists, there was no change in their understanding of the "first day of the week." However, during the Semester the students were introduced to the writings of Christians such as Tilden Edwards, Marva Dawn, Wayne Mueller, and Dorothy Bass who interpret Sabbath as "any time of rest" designated by the one wishing to reserve one day in seven for ceasing one's regular activities. Consequently, the students had been made aware of the Sabbath as "any time of rest" for some Christians and may have scored this item with reference to that awareness.

I expected a change in the perspectives of the students relative to their understanding of the Sabbath as a legalistic requirement for salvation. A major teaching objective was to give the students a lens through which to view Sabbath relationally-as a special time created by God for the purpose of being intimately connected with those created in His image. It was my goal to enlarge the desire of the students to keep the Sabbath because of their relationship with Christ that they were encouraged to nurture throughout the course via the practice of the spiritual disciplines. So the negative mean 
change represents that objective having been met. Again, the change from considering the Sabbath a "burden" and the change to considering the Sabbath a "delight" and "good news" were among the items that made the most significant positive change, along with recognizing Sabbath to be understood not as "any time of rest."

The second stem question on the survey instrument used for the Pre- and the PostTest asked "Which statement(s) best describe your understanding of Sabbathkeeping?" and each item on table 2 was then listed. Pre- and Post-Test differences in the students' understanding of Sabbathkeeping are shown in table 2.

Table 2. Differences in pre- and post-test means for understanding Sabbathkeeping

\begin{tabular}{|l|r|r|r|r|c|}
\hline Item & Pre-T Mean & SD & Post-T Mean & SD & Difference \\
\hline No work & 3.47 & 1.38 & 3.88 & 1.30 & .41 \\
\hline Family time & 4.44 & .89 & 4.75 & .44 & .31 \\
\hline No business dealings & 4.35 & .81 & 4.52 & .79 & .17 \\
\hline Visiting the sick & 4.12 & 1.10 & 4.26 & .90 & .14 \\
\hline No TV/entertainment & 3.67 & 1.32 & 3.79 & 1.20 & .12 \\
\hline Alone time with God & 4.73 & .57 & 4.67 & .81 & -.06 \\
\hline Church attendance & 3.76 & 1.02 & 3.61 & 1.07 & -.15 \\
\hline Giving Bible studies & 4.26 & .96 & 4.08 & 1.03 & -.18 \\
\hline Community service & 4.26 & .71 & 3.93 & 1.03 & -.33 \\
\hline Choir rehearsal/church meetings & 2.82 & .89 & 2.15 & 1.02 & -.67 \\
\hline
\end{tabular}

5-point scale with $1=$ Strongly Disagree, $5=$ Strongly Agree; $\mathrm{N}=34$ 
Table 2 indicates that the students' understanding of Sabbathkeeping changed greatly as a time not specifically created for "choir rehearsals/church meetings." Moderate change is evident in the students' understanding of Sabbathkeeping as being a time for "no work." There were small changes in the students' understanding of Sabbathkeeping for "community service," "family time," "visiting the sick," and "alone time with God, as well as understanding that Sabbath was not created for mandatory "church attendance" and "giving Bible studies" exclusively. Small changes are also noted in the items "no business dealings" and "no TV/entertainment."

Because one teaching objective was de-cluttering the Sabbath of busyness, I did not expect a positive outcome for "choir rehearsal and church meetings" as an understanding of Sabbathkeeping. However, a positive outcome was expected for "alone time with God" since that was the primary purpose of the de-cluttering.

Another teaching objective was to introduce the Sabbath as informing the rest of the week such that "giving Bible studies" and "community service" need not be limited to the seventh day of the week exclusively. So the negative outcomes for "giving Bible studies" and "community services" were expected. I did not anticipate the negative outcome for "church attendance" although one teaching objective was to distinguish mere church attendance from true worship and/or Sabbathkeeping. The changes in considering Sabbathkeeping as a time for "no work" and for "family" were the two items that made the greatest positive change.

The third stem question on the survey instrument for the Pre- and Post-Test asked, "Which statement(s) best describe your understanding of spiritual formation?" Pre- and Post-Test differences in the students' understanding of Spiritual Formation are in table 3. 
Table 3. Differences in pre- and post-test means for understanding spiritual formation

\begin{tabular}{|l|c|r|c|c|c|}
\hline Item & Pre-T Mean & \multicolumn{1}{l|}{ SD } & Post-T Mean & SD & Difference \\
\hline Being conformed to Christ's image & 4.50 & .75 & 4.91 & .38 & .41 \\
\hline Transforming yourself * & 1.58 & 1.18 & 1.94 & 1.52 & .36 \\
\hline Heart-shaping & 4.55 & .66 & 4.85 & .36 & .30 \\
\hline Sanctification & 4.23 & .85 & 4.50 & .71 & .27 \\
\hline Growing up in Christ & 4.64 & .54 & 4.85 & .36 & .21 \\
\hline Baptism of the Holy Spirit & 4.20 & 1.09 & 4.29 & .94 & .09 \\
\hline
\end{tabular}

5 -point scale with $1=$ Strongly Disagree, $5=$ Strongly Agree; $\mathrm{N}=34$

* Reverse scoring indicated (Reverse items: $1=$ Strongly Agree and $5=$ Strongly Disagree)

Moderate changes in the students' understanding of spiritual formation relative to "being conformed to Christ's image" and "transforming yourself" are indicated in table 3. There were small changes in the students' understanding of spiritual formation with reference to "heart-shaping," "sanctification" and "growing up in Christ," and "baptism of the Holy Spirit."

A major teaching objective for the entire semester was to define and to unpack the concept of spiritual formation as "the process of being conformed to the image of Christ for the sake of others." As such, a positive outcome was expected for "being conformed to Christ's image." I also anticipated the positive outcome for "transforming yourself" which was reverse scored and indicated the degree to which the students learned that transformation was not their work but the work of the Holy Spirit. The change in the students' understanding of spiritual formation changed positively in every aspect.

${ }^{5}$ Mulholland, Invitation to a Journey, 12. 
The fourth stem question of the survey instrument used for the Pre- and Post-Test asked "Which statement(s) best describe your understanding of spiritual disciplines?" and each item in table 4 was then listed. Pre- and Post-Test differences in the students' understanding of Spiritual Disciplines are shown in table 4.

Table 4. Differences in pre- and post-test means for understanding spiritual disciplines

\begin{tabular}{|l|c|c|c|c|c|}
\hline Item & Pre-T Mean & SD & Post-T Mean & SD & Difference \\
\hline Spiritual restrictions * & 3.11 & 1.43 & 4.09 & 1.13 & .98 \\
\hline Door to liberation & 3.70 & 1.31 & 4.55 & .66 & .85 \\
\hline Spiritual punishment * & 4.00 & 1.26 & 4.79 & .64 & .79 \\
\hline Spiritual rules for salvation * & 2.79 & 1.27 & 3.32 & 1.25 & .53 \\
\hline Avenues of grace & 3.88 & .98 & 4.05 & 1.18 & .17 \\
\hline Sowing to the Spirit & 4.14 & .92 & 4.33 & .92 & .19 \\
\hline
\end{tabular}

5-point scale with $1=$ Strongly Disagree, $5=$ Strongly Agree; $\mathrm{N}=34$

${ }^{*}$ Reverse scoring indicated (Reverse items: $1=$ Strongly Agree and $5=$ Strongly Disagree)

This table reveals that the students' understanding of spiritual disciplines changed greatly in the items of "spiritual restrictions," "door to liberation," and "spiritual punishment." Moderate change in the students' understanding of spiritual disciplines is evidenced in the item "spiritual rules for salvation." The remaining items, "avenues of grace" and "sowing to the Spirit," indicate small changes in the students' understanding of the spiritual disciplines.

To some extent most of the students had practiced some of spiritual disciplines prior to the course but were unfamiliar with the terminology and the variety of spiritual disciplines available for their growth toward wholeness in Christ. Students were required 
to decide upon a "rule for life" each week that would govern their practice of the spiritual discipline(s) for a seven-day period. They were also encouraged to experiment with spiritual disciplines that were new to them and to choose some that nurtured the shadow side of their temperament types for the purpose of developing holistic spirituality.

This table represents the major change in the students' understanding of spiritual disciplines from "spiritual restrictions," "spiritual punishment," and "spiritual rules for salvation" to the "door to liberation." A positive outcome was expected based on the students' weekly practice of the spiritual disciplines throughout the course.

The final stem question of the survey instrument used as the Pre- and Post-Test asked "Which statement(s) best describe your understanding of how salvation is obtained?" and each item in table 5 was then listed. Pre- and Post-Test differences in the students' understanding of how salvation is obtained are shown in table 5.

Table 5. Differences in pre- and post-test means for understanding obtaining salvation

\begin{tabular}{|l|c|c|c|c|c|}
\hline Item & Pre-T Mean & SD & Post-T Mean & SD & Difference \\
\hline By having faith in God \& being good * & 2.7 & 1.51 & 2.9 & 1.44 & .20 \\
\hline By being good * & 4.1 & 1.18 & 4.4 & 1.04 & .30 \\
\hline As a free gift from God & 4.8 & .36 & 5.0 & .00 & .20 \\
\hline By being a good member of a church * & 4.4 & 1.02 & 4.5 & .79 & .10 \\
\hline
\end{tabular}

5-point scale with $1=$ Strongly Disagree, 5 = Strongly Agree; $\mathrm{N}=34$

* Reverse scoring indicated (Reverse items: $1=$ Strongly Agree and $5=$ Strongly Disagree) 
Table 5 shows small changes in the students' understanding of how salvation is obtained because their scores started out so high.

All of the outcomes represented in table 5 were expected as a key teaching objective was to convey the biblical doctrine of grace such that students learned that salvation is "a free gift from God." This category was included in the survey to address the students' understanding of the relationship between Sabbath/Sabbathkeeping (law) and salvation (grace). Although, on the Pre-Test, most of the students acknowledged a theoretical knowledge of being "saved by grace through faith" (Eph 2:8), there was a positive change in their understanding over the course of the Semester.

\section{Evaluation of the Quantitative Data}

The purpose of this research was to examine the influence of a spiritual formation course on the perspectives of African American Oakwood University students on Sabbath and Sabbathkeeping as a spiritual discipline. The tables reflected the differences in the Pre-Test Means and the Post-Test Means in the students' understanding of Sabbath, Sabbathkeeping, spiritual formation, spiritual disciplines and how salvation is obtained.

Table 1 indicated that, key among the positive outcomes, was that students who initially perceived of Sabbath as a "burden" understood it as a "delight" and "good news" by the end of the course, but they recognized that it is also not to be understood as "any time of rest." Table 2 demonstrated the influence of the course on the perspectives of the students as related to their understanding of Sabbathkeeping, particularly in the positive differences in the "no work" and "family time" items. The negative differences also indicated the influence of the course on the perspectives of the students who, by the end of the semester, seemed to understand the difference between Sabbathkeeping and 
busyness and that mere church attendance does not constitute worship and/or Sabbathkeeping.

Table 3 reflected positive changes in the students' understanding of spiritual formation. Most significant in the outcomes is their understanding that being spiritually formed is not a process under human control. Table 4 evidenced the greatest positive changes in the students' understanding as they moved from perceptions of spiritual disciplines as "spiritual restrictions," "spiritual punishment," and "spiritual rules for salvation," to the "door to liberation."

Table 5 showed the positive outcomes in the students' understanding of how salvation is obtained although most students indicated from the outset a theoretical knowledge of this concept. The data also showed that the students' understanding of the relationship between "being a good member of a church" and obtaining salvation changed positively.

\section{Interpretation of Qualitative Data}

All of the items in table 6 were taught as appropriate activities for Sabbath to some degree. During class after the midpoint of the semester, the students played a version of the game "Scattergories" that required each student to independently write down as many Sabbathkeeping activities they could think of within 30 seconds. The students were initially told that the winner would be the one with the most points, but in actuality, a point could only be earned by having an answer no one else had written down. At the end of the time limit, the students were informed of the way points were earned and then each student had the opportunity to share one activity from her/his list with the rest of the class while I wrote that activity on the board. In the end all the 
activities identified by the students were on the board, winners were identified, and our discussion of the listed activities ensued. I then shared the principles developed by Gregory Allen for determining appropriate Sabbathkeeping activity as follows:

Principle 1: Is the deed in question a vice? (See Rom. 1:24-32; 1 Cor. 5:19-21; Gal. 5:19-21) Principle 2: Is the action appropriate to our measure of faith? (See Rom. 12:3; cf. Rom. 4:20; 1 Cor. 12:9; Rom. 12:6) Principle 3: Do we as individuals have doubts about its appropriateness? (See Rom. 14:14, 23) Principle 4: Are we as individuals fully convinced that an action is proper for us? (See Rom. 14:5, 14; cf. Phil. 1:25) Principle 5: Does the behavior give expression to love for the others in the community? (See 2 Cor. 5:14; cf. 1 Cor. 8:1) Principle 6: Does the action glorify God in Christ, give thanks, and anticipate Christ's second coming? (See 1 Cor. 31-33; Rom. $1: 21 ; 15: 5,6)^{6}$

Table 6 reflects the responses to the following open-ended questions on the survey instrument used as the Pre-Test and Post-Test: "Explain in detail what you do to "keep the Sabbath holy" and "Explain in detail what you refrain from doing to "keep the Sabbath holy'." It reveals that of the twenty activities listed, there were large increases in the Post-Test responses to half of these items. These increases may well reflect the teaching after the midpoint of the semester when the students were introduced to principles for determining appropriate Sabbathkeeping. There were five times as many students "reading spiritual/inspirational books" as an activity to keep the Sabbath holy by the end of the course as compared to the beginning of the course. "Nature walks" and "resting the mind and body" showed that four times as many students at the end of the semester engaged in these activities as a means of keeping the Sabbath holy than at the beginning of the semester. The number of students "spending time alone with God" as a way to keep the Sabbath holy increased more than when Pre-Tests results are compared

\footnotetext{
${ }^{6}$ Allen, "How Shall I 'Keep' the Sabbath Holy?" 23-25.
} 
with Post-Test results. And the increase of students who remembered to "open/close the Sabbath" as a practice to keep the Sabbath holy increased by $21 / 2$ times as indicated by the comparative data.

Table 6. Pre-test/Post-Test differences in Sabbath activities

\begin{tabular}{|c|c|c|c|}
\hline Activity & Pre-Test $(\mathrm{N}=34)$ & Post-Test $(\mathrm{N}=34)$ & Difference \\
\hline Spend alone time with God & 4 & 13 & 9 \\
\hline Rest mind and body & 3 & 12 & 9 \\
\hline Nature walks & 2 & 8 & 6 \\
\hline $\begin{array}{c}\text { Think about Jesus/spiritual } \\
\text { things }\end{array}$ & 10 & 15 & 5 \\
\hline Pray & 6 & 11 & 5 \\
\hline Read spiritual/inspirational \\
books & 1 & 5 & 4 \\
\hline Open/close Sabbath & 2 & 5 & 3 \\
\hline Keep the law & 3 & 1 & -2 \\
\hline Prepare in advance & 5 & 7 & 2 \\
\hline Count my blessings & 3 & 4 & 1 \\
\hline Sing & 2 & 3 & 1 \\
\hline Fellowship & 15 & 15 & 0 \\
\hline Whatever is pleasing to God & 2 & 2 & 0 \\
\hline Visit the sick & 2 & 1 & -1 \\
\hline Read the Bible & 11 & 9 & -2 \\
\hline Witness/Ministry & 5 & 3 & -2 \\
\hline Eat & 6 & 3 & -3 \\
\hline Community outreach & 5 & 2 & -3 \\
\hline Attend religious services & 24 & 2 & -3 \\
\hline
\end{tabular}


Praying, meditating on Jesus, singing, preparing in advance, and counting blessings also showed increases of more than twice as many students doing these activities to keep the Sabbath holy at the end of the term as compared to their reported Sabbathkeeping activities at the beginning.

I expected these results as one of the teaching objectives of the course to identify and provide opportunities to experience a variety of ways of keeping the Sabbath holy and special because of the intimate encounters and engagements possible with the Lord of the Sabbath. As all of the high scores indicate primarily solitary activities, it is possible that the low scores actually reflect the integration of three teaching objectives for the course: (1) that personal devotional time or worship, everyday and especially on Sabbath, is more important than fellowship because it informs and shapes fellowship; (2) that such activities as "reading the Bible," "attending religious services," "witnessing ministry," "community outreach," and "visiting the sick" do not have to be limited to Sabbath hours as the Sabbath should inform and shape the activities of Christians every day; and (3) that instead of the passively "listening to Christian music" on Sabbath, one can keep the Sabbath holy by "singing" to God.

All of the items in table 7 were taught as inappropriate activities for Sabbath to some degree. During class after the midpoint of the semester, when the students played a version of the game "Scattergories," they were also asked to independently write down as many activities to refrain from on the Sabbath that they could think of within a subsequent 30 -second timeframe. Again, the students were initially told that the winner would be the one with the most points, but in actuality, a point could only be earned by having an answer no one else had written down. At the end of the 60 seconds, the 
students were informed of the way points were earned and then each student had the opportunity to share one activity from her/his list with the rest of the class while I wrote that activity in a listing on the board. In the end all the activities identified by the students were on the board, winners were identified, and our discussion of the listed activities ensued. I then shared the principles developed by Gregory Allen for determining appropriate Sabbathkeeping activity as noted previously.

Table 7: Differences in "what you refrain from doing to keep the Sabbath holy"

\begin{tabular}{|l|c|c|c|}
\hline Activity & Pre-Test $(\mathrm{N}=34)$ & Post-Test $(\mathrm{N}=34)$ & Difference \\
\hline No eating out & 2 & 5 & 3 \\
\hline Not doing my own pleasure & 2 & 5 & 3 \\
\hline No games & 1 & 3 & 2 \\
\hline Try not to shop & 3 & 4 & 1 \\
\hline Avoid certain people & 1 & 1 & 0 \\
\hline No internet & 1 & 1 & 0 \\
\hline No self-indulgence & 1 & 1 & 0 \\
\hline No stress or tension & 1 & 1 & 0 \\
\hline Not a lot of arguing & 1 & 1 & 0 \\
\hline No business dealings & 5 & 4 & -1 \\
\hline No worldly thoughts & 6 & 5 & -1 \\
\hline No secular conversation & 15 & 12 & -3 \\
\hline No secular music & 8 & 5 & -3 \\
\hline No sports & 8 & 5 & -3 \\
\hline No secular movies & 6 & 1 & -5 \\
\hline No television & 28 & 22 & -6 \\
\hline
\end{tabular}


Of the sixteen items in table 7 , more than half of the responses relative to activities students refrain from in order to keep the Sabbath holy either increased or remained the same when Post-Tests answers are compared with those from Pre-Tests. These increases may well reflect the teaching after the midpoint of the semester when the students were introduced to principles for determining appropriate Sabbathkeeping. Three times as many students indicated that playing and/or watching "no games" on the Sabbath is a means of keeping the day holy. The table also indicates that, based on the Pre-Test survey results from the first day of class to the Post-Test survey results from the last day of class, there were $21 / 2$ times the no. of students who determined that "no eating out" and "not doing my own pleasure" on the Sabbath were activities to abstain from in order to keep the Sabbath holy. And more students decided since completing the Pre-Test to "try not to shop" in order to keep the Sabbath holy, as indicated on the results of the Post-Test.

Four of the seven low scoring items on table 7 can be placed in the category of entertainment (visual/auditory, auditory, or physical). Further research is warranted to explain these findings.

I was also surprised that the percentage of students who identified "no business dealings" as a practice to facilitate keeping the Sabbath holy decreased over the course of the semester as evidenced by comparing Pre- and Post-Test scores. Institutional records indicate that most students attending Oakwood University need financial assistance. The demographic data for the survey asked for the employment status of the student, but it did not request information relative to family income or the extent to which students were self-supporting. Further research would be helpful to determine the relationship between 
income and refraining from business dealings, including work, when assessing what Seventh-day Adventist Christians refrain from as means to keep the Sabbath holy.

Table 8 indicates responses to the open-ended question, "Explain how your attitude about the seventh day of the week has changed since you first learned about the Sabbath." Because the question is open-ended, it created the possibility for "change" to be interpreted broadly and variously, in light of the religious backgrounds of the students.

Table 8. Differences in attitude change about the seventh day as Sabbath

\begin{tabular}{|l|c|}
\hline Attitude Change & Post-Test \\
\hline More important to me & 2 \\
\hline No change & 1 \\
\hline Changed for the good & 1 \\
\hline Welcome vacation & 1 \\
\hline Sigh of relief & 1 \\
\hline
\end{tabular}

$\mathrm{N}=34$

Table 8 totally reflects my expectations. Because all the students self-identified as Seventh-day Adventist Christians on the Pre-Test, it was anticipated that every survey participant had a general knowledge of the Sabbath as the seventh day of the week. However, as reported in chapter 4, 27 were born into Seventh-day Adventist Christian families; 8 had been Seventh-day Adventist Christians over 5 years and 5 had been. Seventh-day Adventist Christians 1-5 years. It was expected, therefore, that levels of change with regard to understanding and appreciation of the seventh-day Sabbath would vary from students who were multi-generational Seventh-day Adventist Christians to 
students who were relatively new to the denomination and its teachings. The attitude change about the seventh day of the week as Sabbath recorded as "more important to me" was expected as one of the teaching objectives of the Semester was to present Sabbath relationally rather than propositionally. One student wrote: "I now understand that the Sabbath is not just a commandment--that its main focus is not 'not working.' The main focus of Sabbath is to spend intimate time with God to an extent that we could not throughout the week. It is a gift, not a restraint."

Table 9 provides the responses to the open-ended question, "Explain how your attitude about the seventh day of the week has changed since you first learned about Sabbathkeeping." Again, because the question is open-ended, it created the possibility for "change" to be interpreted broadly and variously, in light of the religious backgrounds of the students.

Table 9. Differences in attitude change about Sabbathkeeping

\begin{tabular}{|c|c|}
\hline Attitude Change & Post-Test $(\mathrm{N}=34)$ \\
\hline More prepared & 4 \\
\hline Enjoyment & 2 \\
\hline Rest is beneficial to growth in Christ & 1 \\
\hline Special time of liberation/celebration & 1 \\
\hline Respect & 1 \\
\hline Rules and regulations & 1 \\
\hline Burdened & 1 \\
\hline
\end{tabular}


Table 9, like table 8, generally reflects my expectations. I expected that levels of change with regard to understanding and appreciation of Sabbathkeeping would vary from students who were multi-generational Seventh-day Adventist Christians to students who were relatively new to the denomination and its teachings. The attitude changes about Sabbathkeeping recorded as "more prepared" and "enjoyment" were anticipated as one of the teaching objectives of the semester was to present Sabbathkeeping as an opportunity for encounter with divinity. One student stated: "Sabbathkeeping must be intentional to a certain extent, just as you plan a date." Another said: "When I was younger, I didn't think of it as a relief from the stress and cares of this world as I do now."

The attitude changes recorded as "rules and regulations" and "burdened" were not anticipated in light of the emphasis on developing an intimate, loving relationship with the Lawgiver Who is the Creator and Lord of the Sabbath as the means for appreciating and enjoying Sabbath as a special time to be with Him. However, the importance, significance and relevance of God's law as lyrics of love were also affirmed and could be the basis of these responses.

Table 10 offers the responses to the open-ended question, "explain what you anticipate your commitment about Sabbath and Sabbathkeeping will be once you graduate." Once again, because the question is open-ended, it creates the possibility of interpreting "commitment" and the phrase "once you graduate" in multiple ways. 
Table 10. Differences in anticipated future commitment to Sabbathkeeping

\begin{tabular}{|c|c|c|c|}
\hline Anticipated Future Commitment & Pre-Test (N=34) & Post-Test (N=34/ & Difference \\
\hline Stronger & 3 & 6 & 3 \\
\hline Better & 4 & 4 & 0 \\
\hline More delighted to keep Sabbath & 1 & 1 & 0 \\
\hline Way of life & 1 & 1 & 0 \\
\hline Same as before & 9 & 6 & -3 \\
\hline More committed & 5 & 2 & -3 \\
\hline
\end{tabular}

Like tables 8 and 9 , table 10 reflects my expectations. With the exception of the increase in two times the no. of students who, since the Pre-Test, anticipate a "stronger" future commitment of Sabbathkeeping on the Post-Test, reflecting, perhaps, relatively new adherents to the doctrines of Seventh-day Adventist Christians, the remaining items tend to suggest that most of the participants may have made the greatest level of commitment to future Sabbathkeeping prior to the course as indicated by one Pre-Test response from a multi-generational Seventh-day Adventist Christian female that read, "It will become such an intimate experience with God that I won't know what to do with myself but tell of His glory."

Table 11 was created to identify and evaluate the differences in the responses to the first of the kinesthetic/behavioral questions on the survey by category. Descriptions of the categories of qualitative responses to kinesthetic/behavioral questions used are listed below:
A. Solitary--spiritual (i.e., reading, listening to sermons/music, alone with God, praying, meditating, journaling, arts and crafts)
B. Solitary-general (i.e., Facebook, sleeping, letter writing) 
C. Communal-spiritual (i.e., praying together, spiritual conversations, counseling, Bible games; Bible study)

D. Communal-general (i.e., potlucks, hanging out/fellowshipping)

E. Outreach activities (i.e., Bible studies, visiting the sick, distributing literature)

F. Church-related meetings (i.e., AY, Sabbath School, church, choir rehearsal)

G. Nature-related activities (i.e., walks, nature reserve visits, zoos, bird-watching, beach)

Table 11. Differences in qualitative kinesthetic/behavioral responses by category ("What do you do to keep the Sabbath holy?")

\begin{tabular}{|c|c|c|c|}
\hline Category & $\begin{array}{c}\text { Pre-Test Responses } \\
(\mathrm{N}=34)\end{array}$ & $\begin{array}{c}\text { Post-Test Responses } \\
(\mathrm{N}=34)\end{array}$ & Difference \\
\hline Solitary-spiritual & 14 & 22 & 8 \\
\hline Solitary-general & 28 & 34 & 6 \\
\hline Communal-general & 0 & 1 & 1 \\
\hline Outreach activities & 2 & 3 & 1 \\
\hline Nature-related activities & 1 & 1 & -1 \\
\hline Church-related meetings & 3 & 2 & -4 \\
\hline Communal-spiritual & 5 & 1 & \\
\hline
\end{tabular}

It is interesting to note that the activities in the categories with the greatest percentages of increase ("solitary—spiritual" and "solitary—general) are those that suggest a preference for activities performed alone. And the decrease in the number of students who prefer "communal-spiritual" activities is a corollary to the great increases in preference for solitary activities. I expected a decrease in the number of students who associate "church-related meetings" with activities to keep the Sabbath holy as meeting a 
course objective to identify the Sabbath as a time for more than "kingdom business" as such meetings are often called.

\section{Evaluation of Qualitative Data}

When individual participant Pre-Test responses were compared with that individual participant's Post-Test responses on the question "What do you do the keep the Sabbath holy?" there were 31 positive responses as compared to 3 negative ones.

When individual participant Pre-Test responses were compared with that individual participant's Post-Test responses on the question "What do you refrain from doing to keep the Sabbath holy" all 34 responses were positive.

When individual participant Pre-Test responses were compared with that individual participant's Post-Test responses on the question to explain "How your attitude about the seventh day of the week has changed since you first learned about the Sabbath" there were 33 positive responses and 1 that remained the same.

When individual participant Pre-Test responses were compared with that individual participant's Post-Test responses on the question to explain "How your attitude about the seventh day of the week has changed since you first learned about Sabbathkeeping?" there were 31 positive responses and 3 that remained unchanged.

When individual participant Pre-Test responses were compared with that individual participant's Post-Test responses on the question to explain "What do you anticipate your commitment about Sabbath and Sabbathkeeping will be once you graduate?" all 34 responses were positive.

It is my evaluation that the qualitative data gives evidence that the influence of the spiritual formation course (offered Spring Semester 2009) on the perspectives of African 
American Oakwood University students on Sabbath and Sabbathkeeping as a spiritual discipline has been a positive intervention in addressing the identified ministry issue. 


\title{
CHAPTER 6:
}

\section{SUMMARY, CONCLUSIONS, AND RECOMMENDATIONS}

\begin{abstract}
Summary
The purpose of this dissertation was to examine a theological issue in ministry, namely, the influence of a spiritual formation course on the perspectives of Sabbath and Sabbathkeeping as a spiritual discipline among African-American Oakwood University students. As an appropriate intervention to address this specific ministry challenge, a spiritual formation course was developed to enable students to identify a holistic understanding and experience of Sabbath and Sabbathkeeping as a spiritual discipline. Another important objective was to provide tools for students to differentiate between Sabbath and Sabbathkeeping as spiritual disciplines and Sabbath and Sabbathkeeping as propositional truth and to evaluate the significance of the difference.

Although most students who attend Oakwood University are self-identified Seventh-day Adventist Christians, from general observation of their activities, conversations, and attitudes displayed on any given Friday night and/or Saturday (i.e., Sabbath), it was easy to conclude that many neither enter nor exit their collegiate experience with a holistic understanding or experience of Sabbath and Sabbathkeeping as "a way we can be receptive to God.". It was safe to assume that they did not view

${ }^{1}$ Allen, Rest as a Spiritual Discipline, 35.
\end{abstract}


Sabbath/Sabbathkeeping as a spiritual discipline to be offered as a means of "radical abandonment to God in love and equally radical availability to God for others so that in all circumstances and relationships our life becomes one in whom God is present for others." Instead, for many students, Sabbath and Sabbathkeeping was presumed to be primarily regarded as one of many "general regulations on student conduct" as recorded in the Student Handbook since "by enrolling at Oakwood College, a student signifies his/her support of and willingness to live in accordance with the codes, rules, regulations and objectives of the University and the standards of the Seventh-day Adventist Church." ${ }^{3}$

To provide an overview of the project to enhance the understanding of Sabbath and the keeping of Sabbath, a summary of each chapter of this project dissertation is given here.

Chapter 1, the "Introduction," presented my personal history, the statement of the task, the statement of the problem, the statement of justification, expectation for the project, delimitations, limitations, definition of terms, methodology, and a summary of the chapters.

Chapter 2, "Biblical/Theological Foundations," sought to answer the following three questions: What biblical evidence is there for Sabbath observance? How does the Bible describe Sabbathkeeping? Is Sabbath observance still in effect for Christians?

${ }^{2}$ Mulholland, The Deeper Journey, 139.

${ }^{3}$ The Division of Student Services of Oakwood College, "Oakwood College Student's Bill of Rights," Student Handbook 2007-2009, 11. 
The study revealed that the preponderance of scriptural evidence from both the Old Testament and the New Testament dictates repeatedly and consistently the basis for Sabbath observance.

Sabbathkeeping was examined from Jewish, first-day Christian, and Seventh-day Adventist Christian perspectives in this chapter.

Jewish understanding on the relevance of the Sabbath command for Christians is mixed depending on whether Sabbathkeeping is linked to Exodus 30 or Deuteronomy 5. For those who are swayed by the creation account in Genesis, Sabbath observance is universally binding on all people at all times. But for those who are persuaded by the liberation language (which exists in both renderings), Sabbath observance is perceived as an exclusively Jewish practice.

Christian understanding of the fourth commandment as applied since the resurrection of Jesus Christ is also diverse. Most do not subscribe to a literal interpretation that requires the Sabbath to be observed on the seventh-day of the week or Saturday. But some do acknowledge the concept of Sabbath as beneficial and binding although they choose to select which day to designate as "sabbath." The day most often chosen is the first day of the week or Sunday which is also called "the Lord's day."

Seventh-day Adventist Christians are consistent in their affirmative response to the question of Sabbath observance for Christians. It was concluded that not only do Seventh-day Adventist Christians understand Sabbath observance to be in effect for themselves, for all Christians and for the entire human family, but that the practice of Sabbathkeeping by Seventh-day Adventist Christians is in accordance with their stated beliefs. 
Chapter 3, "Literature Review," revealed that the spiritual formation of college and university students is more much a topic of interest than it has been since the Enlightenment stressed human reasoning over faith and obedience. And studies regarding the role of higher education in the spiritual development are on the rise as well. It is clear, however, that far more research is needed, particularly with regard to the spiritual formation of African American students and the practice of Sabbathkeeping as a spiritual discipline among college and university students.

Unlike public college and universities that must always balance "church and state" issues, private liberal arts colleges and especially religiously-affiliated institutions of higher learning have the great privilege and responsibility to examine the philosophical frameworks that dictate curriculum and co-curricular ethos and content. As emerging adults choose to matriculate at these institutions, they should be able to expect that consistent, coherent, and cogent opportunities for engaging in academic courses, servicelearning experiences, student organizations, faculty mentoring, and other campus-based activities are available to them for their holistic development with particular emphasis on their spiritual formation.

In Chapter 4, "Methodology and Implementation Narrative," the ministry context and intervention for this research endeavor was described, which was the course RP131: Spiritual Formation for Ministry offered by the Department of Religion and Theology during Spring Semester 2009 at Oakwood University. The purpose of the study was to discern the influence of this course on the perspectives of African American Oakwood University students on Sabbath and Sabbathkeeping as a spiritual discipline. The 
research methodology of this project was a combination of qualitative and quantitative methods.

On the first and last days of the semester, students enrolled in RP131: Spiritual Formation for Ministry completed the same survey which was designated Pre-Test and Post-Test. The survey was formulated to uncover what students knew about Sabbath and Sabbathkeeping (cognitive); what students did and/or refrained from doing on Sabbath (kinesthetic/behavioral); and how students felt about Sabbath and Sabbathkeeping (affective).

The research intervention included covenant group assignments, lectures and discussions, weekly reading assignments and reports, weekly practice of the rule of life and the spiritual disciplines, homework, synagogue worship, weekend retreat, resource files, and reflection papers.

Chapter 5, "Outcomes and Evaluation," presents the findings of the quantitative and qualitative data and evaluates their significance.

All of the quantitative data, which reflected the differences in the pre- and posttest means, indicated positive outcomes. Key positive outcomes are the following:

- Students who initially perceived Sabbath as a "burden" came to understand it as a "delight" and "good news."

- Students' understanding related to Sabbathkeeping as a time of "no work" and a time for family improved.

- Students' understanding of spiritual formation as a process that is not under human control increased. 
- Students who initially perceived of spiritual disciplines as "spiritual restrictions, punishment or rules for salvation" came to understand them as "the door to liberation."

- Students' understanding of the relationship between "being a good member of a church" and obtaining salvation improved.

The qualitative data indicate that the influence of the spiritual formation course on Sabbath and Sabbathkeeping as a spiritual discipline has been a positive intervention, particularly in the area of anticipated commitment to Sabbathkeeping beyond graduation.

At the end of the last day of class, the students surprised me with the unanticipated gift of a pewter Shabbat Fountain (pictured in the Appendices) to show their appreciation for what they had learned and to assure me that what had been learned was indelibly imprinted on their hearts. They said they wanted to gift to always remind me that their appreciation and commitment to Sabbath and Sabbathkeeping as a spiritual discipline was forever. Having never seen nor even heard of a Shabbat Fountain, I asked how they had learned of it and how was it to be used. I was told that they discovered it as a result of their synagogue worship experience and ordered one for me online.

The proper name for this gift is a Kiddush Fountain and the Kiddush is the Jewish ceremony in which the Sabbath is sanctified. "On Friday night, when the Sabbath begins, the Kiddush ceremony is carried out before sitting down to the Sabbath meal."4

A Kiddush fountain is traditionally used to make Kiddush for Shabbat and Jewish Holidays. They are very elegant and unique. When the ceremony of Kiddush is made with the blessing over the wine, the wine is poured into the top of the fountain.

${ }^{4}$ Kiddush ceremony, www.myjewishlearning.com/practices (accessed May 2009). 
Everyone is always captivated as the wine trickles down through the Kiddush fountain filling each Kiddush cup for everyone to drink. ${ }^{5}$

I continue to have the privilege of teaching RP131: Spiritual Formation for Ministry at Oakwood University and the course curriculum has included "Sabbath and Sabbathkeeping as a Spiritual Discipline" since Spring Semester 2009 when the research for this dissertation began. This Doctor of Ministry project has shaped and informed the way that aspect of the course is taught and has benefited the students and me.

The study does not provided empirical data to support whether or not the responses of the students to my assignments and activities were unique to the cultures of African Americans or Africans in the diaspora generally because the scope of this study, as stated in the "Delimitations," did not included participants who were not "African American" according to the U. S. Census Bureau (see "Definitions"). Requirements for participation in the study did not differentiate between citizenship or place of birth. Only ethnicity and residency were considered for eligibility.

\section{Conclusions and Recommendations for Practice}

Conclusion 1: A college-level spiritual formation course that encourages an intimate, loving relationship with the Lawgiver Who is the Creator and Lord of the Sabbath as the means for appreciating and enjoying Sabbath as a special time to be with Him can change the perspectives of students who view Sabbath negatively to perceiving it positively, joyfully, correctly, holistically, relationally and with greater commitment.

Recommendation 1: Professors who teach the doctrine of Sabbath and Sabbathkeeping should put more emphasis on the great commandment to love the

${ }^{5}$ Kiddush fountain, www.traditionsjewishgifts.com (accessed May 2009). 
Lawgiver Who is the Creator and Lord of the Sabbath with all one's heart, soul, mind, and strength (Mark 12:30) so that the fourth commandment of the Decalogue becomes the reminder it was intended to be of the unique opportunity human beings are given to be especially blessed.

Conclusion 2: A college-level spiritual formation course that de-emphasizes legalistic obedience to the law of God in order to encourage an intimate, loving relationship with the Lawgiver Who is the Creator and Lord of the Sabbath as the means for appreciating and enjoying Sabbath as a special time to be with Him can change the perspectives of students who view Sabbath merely as an opportunity for "alone time with God" or as just an ordinary day to choosing Sabbath as time for fellowship and ministry.

Recommendation 2a: Professors should present biblical instruction on Sabbath and Sabbathkeeping with integrity, consistency, sensitivity, completeness, and evenhandedness while emphasizing the priority of Jesus when He said, "If you love Me, keep My Commandments" (John 14:15).

Recommendation 2b: Professors should present biblical instruction on Sabbath and Sabbathkeeping with integrity, consistency, sensitivity, completeness, and evenhandedness, highlighting how Jesus took advantage of the special opportunities for fellowship and ministry that the Sabbath presented.

Conclusion 3: A college-level spiritual formation course that gives students a lens through which to view Sabbath relationally and a paradigm for perceiving Sabbath as an expression of God's beneficence can change the perspectives of students who view Sabbath as a legalistic requirement for salvation to a specific (the seventh) day of the week that informs and shapes a way of life every day of the week and a "token of 
allegiance to God's authority"6 rather than just a "sealing for salvation."

Recommendation 3: A college course that includes biblical instruction on the doctrine of Sabbath observance should emphasize that although "the seal of the living God is placed upon those who conscientiously keep the Sabbath of the Lord,"7 "the seal of God will be placed on those who love Him." based on and motivated by love for the Creator and Lord of the Sabbath.

Conclusion 4: A college-level spiritual formation course that provides biblical instruction on Sabbath and Sabbath observance in the context of spiritual formation as a balance of dependence on the power of the Holy Spirit and "discipline for the purpose of godliness" (1 Tim 4:7) through the examination of and engagement in the spiritual disciplines that are foundational to spiritual formation, a strong devotional life, and Spirit-led Christian service can change the perspectives of students who do not regard Sabbath and Sabbath observance as a spiritual discipline to acknowledging Sabbath and Sabbath observance as one of the "means of grace which are tools or conduits through which grace is given that alone can transform the heart."

Recommendation 4: Sabbath and Sabbathkeeping should be taught as a key spiritual discipline that provides extraordinary opportunities for beholding God so that human beings may become "partakers of the divine nature" ( 2 Pet 1:4).

Conclusion 5: A college-level spiritual formation courșe that encourages an

${ }^{6}$ Ellen G. White, The Great Controversy (Mountain View, CA: Pacific Press, 1888), 605.

${ }^{7}$ Ellen G. White, "Ellen G. White Comments - Revelation," Seventh-day Adventist Bible Commentary, ed. F. D. Nichol (Washington, DC: Review and Herald, 1953-57), 7:980.

${ }^{8}$ Ellen G. White, Sons and Daughters of God (Washington, DC: Review and Herald, 1955), 51.

${ }^{9}$ Beasley-Topliffe, The Upper Room Dictionary of Christian Spiritual Formation, 84. 
understanding of Sabbath as a reminder of deliverance and liberation from mandatory, involuntary, uncompensated labor (Deut 5:15) can change the perspectives of students who do not view Sabbath as a time for "no work" to an appreciation for the freedom and provision God supplies without human assistance on Sabbath.

Recommendation 5: Professors who teach college courses that include biblical instruction on Sabbath and Sabbathkeeping should be intentional about presenting God's rationale for the fourth commandment from renderings of the Decalogue in both Exodus (with its creation emphasis) and Deuteronomy (with its liberation emphasis).

Conclusion 6: A college-level spiritual formation course that encourages Sabbath observance based on how the Lawgiver Who is the Creator and Lord of the Sabbath kept the seventh day of the week can change the perspectives of students who do not view "visiting the sick" on Sabbath as a Sabbathkeeping practice to recognizing how many instances of healing and benevolence on the Sabbath are recorded in the Gospels as the practice and custom of Jesus.

Recommendation 6: Students should be encouraged to engage in service-learning projects on Sabbath that could include visiting the sick, assisting administrators as peer counselors/student chaplains, and providing support to campus organizations by facilitating rap sessions on critical topics. Professors of such courses should participate and provide students with guidelines, resources, and evaluation tools.

Conclusion 7: A college-level spiritual formation course that advances the biblical teaching of salvation as unearned and unmerited can change the perspectives of students who view the means of obtaining salvation as "being good," "having faith in 
God and being good," and "being a good member of a church" to receiving "a free gift from God."

Recommendation 7: A key teaching objective for professors who teach collegelevel spiritual formation courses that include the biblical doctrine of salvation must firmly establish the critical relationship between law and grace.

Conclusion 8: Teachers of spirituality in other Adventist colleges and universities must be conscientiously and consistently aware of and genuinely sensitive to the cultural diversity of their student populations so as to present the subject matter in a relevant manner.

Recommendation 8: A teaching objective for teachers of spirituality in other Adventist colleges and universities must include Christian authors, presenters and materials (text, music, art, etc.) from many cultural and ethnic origins so as to make the subject matter as relatable, applicable and helpful as possible to as many students as possible.

Conclusion 9: A college-level spiritual formation course that encourages an intimate, loving relationship with the Lawgiver Who is the Creator and the Lord of the Sabbath as the means for appreciating and enjoying the Sabbath as a special time to be with Him and is modeled by the professor of said course during the week and on the Sabbath in the process of building intentional, loving relationships with the students, taking advantage of curricular and co-curricular opportunities with students on campus and informal but purposeful gatherings in the home of the professor, can change the perspectives of students who view Sabbath negatively to perceiving it and its Creator positively, joyfully, correctly, holistically, relationally and with greater commitment. 
Recommendation 9: Professors who teach college-level spiritual formation and/or other courses that include the doctrine of Sabbath and Sabbathkeeping should not only put more emphasis on the great commandment to be engaged in an ever-deepening, loving, intimate relationship with the Lawgiver Who is the Creator and Lord of the Sabbath, but should seek the means to build intentional, loving relationships with the students, taking advantage of curricular and co-curricular opportunities with students on campus and informal but purposeful gatherings in the home of the professor, thereby demonstrating what is taught and modeling how Jesus taught consistently and continually.

Conclusion 10: A college-level spiritual formation course that encourages an intimate, loving relationship with the Lawgiver Who is the Creator and the Lord of the Sabbath as the means for appreciating and enjoying the Sabbath as a special time to be with Him and includes a weekend retreat situated in natural surrounding near forests and lakes with limited cell phone or internet access and content that provides intentional space and time for prayer, fellowship, praise, worship, silence, solitude, meditating on Scripture, sharing of gifts, freedom to rest, freedom to enjoy nature (mountain climbing, following trails), and a special Communion service can transform the understanding and appreciation of the Sabbath and its Creator.

Recommendation 10: Professors who teach college-level spiritual formation and/or other courses that include the doctrine of Sabbath and Sabbathkeeping should incorporate the laboratory of a weekend retreat to provide students opportunities to experience Sabbath and Sabbathkeeping in the midst and beauty of God's handiwork in 
nature, free from distractions that often hinder their understanding and appreciation of the Sabbath and its Creator.

\section{Recommendation for Additional Research}

Further study to examine gender differences in Sabbathkeeping is recommended as is research to explore cultural Sabbathkeeping differences. 
APPENDIX A

COURSE MATERIALS

- Survey Instrument

- Course Syllabus For RP131: Spiritual Formation For Ministry 


\section{SURVEY INSTRUMENT \\ PARTICIPANT CODE:}

Directions: This survey is designed to evaluate the personal spiritual and theological foundations of the participants relative to Sabbath and Sabbathkeeping. Circle the no. indicating the response for each item that best describes you or your opinions and answer the open-ended questions as completely as possible. Use the back of the sheet if necessary.

\section{Cognitive}

1. Which statement(s) best describes your understanding of Sabbath?

$\begin{array}{ccccc}\begin{array}{c}\text { Strongly } \\ \text { Disagree }\end{array} & & & \text { Agree } \\ 1 & 2 & 3 & 4 & 5 \\ 1 & 2 & 3 & 4 & 5 \\ 1 & 2 & 3 & 4 & 5 \\ 1 & 2 & 3 & 4 & 5 \\ 1 & 2 & 3 & 4 & 5 \\ 1 & 2 & 3 & 4 & 5 \\ 1 & 2 & 3 & 4 & 5 \\ 1 & 2 & 3 & 4 & 5 \\ 1 & 2 & 3 & 4 & 5 \\ 1 & 2 & 3 & 4 & 5 \\ 1 & 2 & 3 & 4 & 5\end{array}$

2. Which statement(s) best describes your understanding of Sabbathkeeping?

- A commandment to be obeyed.

d

- Good news

- A delight.

- A burden

- A way of life

- A spiritual discipline

- The seventh day of the week

- The first day of the week

- Sealing for salvation

- Any time of rest

- Other (explain).

Strongly

Disagree

- Attend Sabbath services

$\begin{array}{lllll}1 & 2 & 3 & 4 & 5 \\ 1 & 2 & 3 & 4 & 5 \\ 1 & 2 & 3 & 4 & 5 \\ 1 & 2 & 3 & 4 & 5 \\ 1 & 2 & 3 & 4 & 5 \\ 1 & 2 & 3 & 4 & 5 \\ 1 & 2 & 3 & 4 & 5 \\ 1 & 2 & 3 & 4 & 5 \\ 1 & 2 & 3 & 4 & 5 \\ 1 & 2 & 3 & 4 & 5 \\ 1 & 2 & 3 & 4 & 5\end{array}$


3. Which statement(s) best describes your understanding of spiritual formation?

Strongly

Disagree

- Sanctification

$\begin{array}{lllll}1 & 2 & 3 & 4 & 5 \\ 1 & 2 & 3 & 4 & 5\end{array}$

- Growing up in Christ

- A process of being conformed into the image of Christ for the sake of others...

- Heart-shaping.

- Transforming yourself in accordance with God's will

- Baptism of the Holy Spirit.

$\begin{array}{lllll}1 & 2 & 3 & 4 & 5 \\ 1 & 2 & 3 & 4 & 5\end{array}$

- Other (explain)

$\begin{array}{lllll}1 & 2 & 3 & 4 & 5 \\ 1 & 2 & 3 & 4 & 5 \\ 1 & 2 & 3 & 4 & 5\end{array}$

4. Which statement(s) best describes your understanding of spiritual disciplines?

Strongly

Disagree

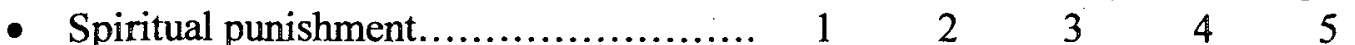

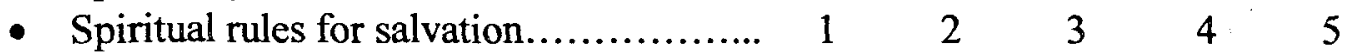

- Avenues of grace......................... $11020 \begin{array}{lllll} & 2 & 3 & 4 & 5\end{array}$

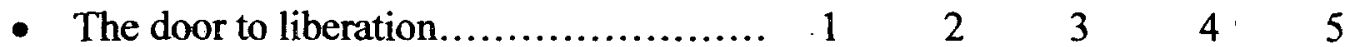

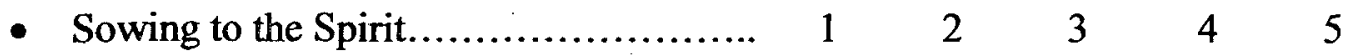

- Spiritual restrictions........................ 1 . $20 \begin{array}{llll} & 3 & 4 & 5\end{array}$

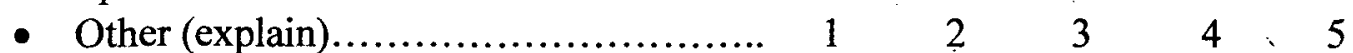

5. Which statement(s) best describe your understanding of how salvation is obtained?

\section{Strongly}

Disagree

- By being good

$\begin{array}{ccccc}1 & 2 & 3 & 4 & 5 \\ 1 & 2 & 3 & 4 & 5 \\ 1 & 2 & 3 & 4 & 5 \\ 1 & 2 & 3 & 4 & 5 \\ 1 & 2 & 3 & 4 & 5\end{array}$

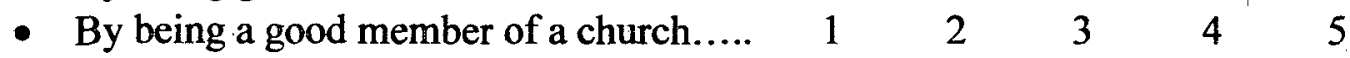

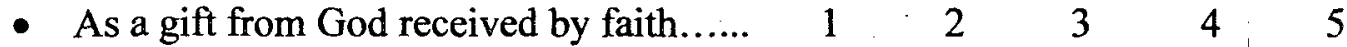

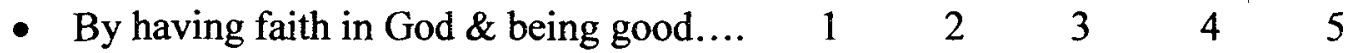

- Other (explain)......................... $1122 \quad 3 \quad 4 \quad 5$

\section{Behavioral}

1. Explain in detail what you do to "keep the Sabbath holy." 
2. Explain in detail what you refrain from doing to "keep the Sabbath holy."

\section{Affective}

1. Explain how your attitude about the seventh day of the week has changed since you first learned about the Sabbath.'

2. Explain how your attitude about the seventh day of the week has changed since you first learned about Sabbathkeeping.

3. Explain what you anticipate your commitment about Sabbath and Sabbathkeeping will be once you graduate. 


\title{
Oakwood University Department of Religion and Theology \\ SYLLABUS FOR RP131: SPIRITUAL FORMATION FOR MINISTRY SPRING SEMESTER 2009
}

Section 1/9:00-9:50 $M$ \&W and Section 2/10:00-10:50 $M$ \&W

\author{
Prerequisites: None \\ Instructor: $\quad$ Professor Ifeoma I. Kwesi \\ Class Location: $\quad$ Moseley Complex, Room 104 \\ Course Credit: Two hours \\ Office Hours: $\quad$ 7:00-8:00, 11:00-12:30, 4:00-7:00 Mondays and Wednesdays \\ Office Location: Moseley Complex, Office 5 \\ Office Phone: $\quad$ 256-736-7360 \\ Email Address: $\quad$ ikwesif@oakwood.edu
}

\section{COURSE DESCRIPTION}

This course is a biblical, theological, historical and practical study of spiritual formation for Christian ministry. Students examine and engage in the spiritual disciplines foundational to a strong devotional life and Christian service. Emphasis is given to the relationship between personal, corporate and social spirituality, particularly the role of the spiritual guide in the development of spiritual formation in others. Laboratory work is required.

\section{COURSE OBJECTIVES}

At the conclusion of this course, the student will be able to:

1. Describe the biblical, theological, and historical foundations of spiritual formation.

2. Discuss the Christological basis for spiritual formation.

3. Describe the spiritual disciplines of the Christian devotional life.

4. Recognize the relationships between personal, corporate and social spirituality.

5. Practice the spiritual disciplines and Christian service.

6. Accept the formative role of the Word in developing personal, corporate, and social spirituality.

7. Critique the role of the spiritual guide.

8. Identify resources for continuing spiritual formation.

\section{TOPICAL OUTLINE OF COURSE}

1. Definitions

2. Biblical, theological, and historical foundations of spiritual formation

3. Formative role of the Word 
4. Spiritual disciplines and the devotional life

5. Corporate spirituality

6. Social spirituality

7. The spiritual guide

8. Resources for continuing spiritual formation

\section{COURSE REQUIREMENTS}

\section{A. CLASSROOM ATTENDANCE AND INTERACTION}

1. Regular attendance. Failure due to absences applies. *

2. Punctuality

a. Three tardys $=1$ unexcused absence.

$b$. Tardiness over ten minutes after the start of class $=I$ unexcused absence.

3. Cell phones and pagers must be turned off during class. Each violation -I unexcused absence.

4. No laptop computers may be used during class. Each violation - 1 unexcused absence.

5. No babysitting during class. Prior arrangements must be made with instructor.

6. No sleeping during class. Each violation $=1$ unexcused absence.

7. Completion of all assignments.

8. Preparation for and participation in classroom discussions and activities.

9. Honesty and integrity.

10. All assignments are due at the start of class. A ten percent penalty applies after class begins.

\section{B. ATTENDANCE ADDENDUM}

"If for any reason the total hours of absence are double the no. of credit hours of the course per Semester, credit may, at the discretion of the instructor, be forfeited and a grade of FA be recorded." (Oakwood University Bulletin, page 53) THIS POLICY WILL BE ENFORCED.

Regarding absences, excuses for absences and assignments missed due to being absent, the following policies apply: (1) no excuse eliminates an absence; (2) documented valid reasons [excuses in writing from resident hall deans, health services, court officers, funeral directors \{obituaries\}, and parents] for being absent will allow students to make up only in-class work missed during the absence; and (3) such work must be made up without one week of return to class.

\section{SPIRITUAL RETREAT}

In order to introduce students to the value of spiritual retreat, discipleship, small groups and bonding to like-minded pilgrims, all students are required to take part in a weekend 
spiritual retreat - March 13-15, 2009. This class cannot be passed unless there is full participation in the retreat.

\section{REFLECTION PAPER}

Each student is to write a reflection paper which synthesizes her/his Semester-long spiritual experience. [In what ways have your grown spiritually? What have you learned about yourself this Semester? What have you learned about God?] This paper is to be 2-3 pages in length, typed and double-spaced. Due: Wednesday, April 22.

\section{E. PRACTICE OF THE SPIRITUAL DISCIPLINES}

The student will spend three hours each week in the practice of spiritual disciplines. Factors that should be kept in mind are as follows:

1. You are free to complete the three hours doing whatever devotional things that you find valuable (i.e., Bible reading, prayer, etc.) Your class lectures and readings will give you some new ideas. This is a wonderful opportunity to experiment with new ways of meeting God. Since prayer is so crucial for the Christian, try to spend $1-1 / 2$ hours weekly in prayer.

2. Unless there is some special reason for change, the three-hour time period should be spread out over at least four days during the week.

3. At the beginning of each week, you should decided what your specific daily "rule" or plan is for each time you have devotions and write it down. More information will be given in class on this practice.

4. You should keep a careful log of your time with God. A form will be provided for this. Make sure for each devotional time you have that you record: (a) date, (b) duration, and (c) a brief summary of how things went (i.e., Did you follow your rule? How did it go? If not, why not?)

5. While for some it may seem a bit artificial to keep track of devotional time, it helps us stay honest with ourselves and God. Doing this is a time-honored practice devoted Christians have often followed.

\section{F. WEEKLY REPORTING}

Students are to use the forms provided for recording the "Practice of the Spiritual Disciplines" as well as the Summary and Evaluation of the "Weekly Reading Assignments. They are to be turned in each Monday, beginning January 26, prior to the start of class. The Summary can be in any form that is understandable and the Evaluation should include what impressed you in either a positive or negative way. Reports should be typed or written legibly and must be complete. 


\section{G. FINAL EXAM/RESOURCE FILE}

There will be no final exam but a resource file is due on April 28 between 10:30 a.m. 12:30 p.m. for RP131-02 and on April 29 between 10:30 a.m. - 12:30 p.m. for RP13101.

1. Each student must acquire an accordion file with a minimum of eight divisions for the purpose of identifying resources for continuing spiritual formation.

2. Suggested divisions of the accordion file include but are not limited to the following topics and must be labeled: Books, Music, Nature, Family, Friends, Sabbath and Sabbathkeeping, Prayer, Meditation, Fasting, Study, Simplicity, Solitude/Silence, Submission, Service, Celebration, Confession, Guidance, and Worship.

3. In each of the divisions, there must be 2 resources for continuing spiritual formation that relate to the topic specified by the labeling. Internet downloads (articles, photographs, etc.) are not permitted.

4. Each resource included must be accompanied by a typewritten paragraph on full sheets of $8 \times 11 \quad 1 / 2$ inch paper that will identify the resource, its history, substance, relevance and application.

5. The evaluation will be based on the evidence of organizational structure, 2 resources and accompanying annotation for each resource.

\section{H. TEXTBOOKS}

[1] Handouts (Davidson, Richard - A Love Song for the Sabbath; Dawn, Marva Keeping the Sabbath Wholly; Heschel, Abraham - The Sabbath) [2] Foster, Richard. Celebration of Discipline (COD); [3] Keller, W. Phillip. A Gardener Looks at the Fruit of the Spirit (GLFS); [4] Mulholland, Robert Invitation to a Journey (ITJ); [5] White, Ellen Steps to Christ (SC). 


\section{Grading System}

\section{COURSE EVALUATION}

Classroom Participation $\quad 10 \%$

Homework $10 \%$

Reflection Paper (April 22) $\quad 15 \%$

Resource File /Final Exam $\quad 20 \%$

Retreat (March 13-15) $\quad 15 \%$

Weekly Reading Reports $\quad 15 \%$

Weekly Practice of the Spiritual Disciplines $\quad \underline{15 \%}$

Grading Scale
$A=95-100$
A- $=90-94$
$\mathrm{B}+=87-89$
$\mathrm{B}=\mathbf{8 3 - 8 6}$
$\mathrm{B}-=80-82$
$\mathrm{C}+=77-79$
$\mathrm{C}=73-76$
$\mathrm{C}-=70-72$
$\mathrm{D}+=67-69$
$\mathrm{D}=63-66$
D- $=60-62$
$\mathrm{F}=59$ and below

\section{COURSE CALENDAR}

$\mathrm{W}: 1 / 14$

$\mathrm{W}: 1 / 21$

M: $1 / 26$

$\mathrm{W}: 1 / 28$

M: $2 / 2$

W: $2 / 4$

M: $2 / 9$

$\mathrm{W}: 2 / 11$

M: $2 / 16$

W: $2 / 18$

M: $2 / 23$

W: $2 / 25$

M: $3 / 9$

W: $3 / 11$

$\mathrm{M}: 3 / 16$

$\mathrm{W}: 3 / 18$

M: $3 / 23$

W: $3 / 25$

M: $3 / 30$

W: $4 / 1$

M: $4 / 6$

W: $4 / 8$

M: $4 / 13$

W: $4 / 15$

$M: 4 / 20$

W: $4 / 22$
Distribution of "Informed Consent Letter," "PRE-TEST" and Syllabus "Importance of Role for Life," SC: Chapter 1, and GLFS: Chapter 1 Reading Report Due on ITJ: Chapters 1-4 and COD: Chapter 1 Quad Pod Presentations on SC: Chapter 2 and GLFS: Chapter 2; Summary Reading Report Due on ITJ: Chapters 5-7 and COD: Chapter 2

Quad Pod Presentations on SC: Chapter 3 and GLFS: Chapter 3; Summary Reading Report Due on ITJ: Chapter 9 and COD: Chapter 3

Quad Pod Presentations on SC: Chapter 4 and GLFS: Chapter 4; Summary Reading Report Due on ITJ: Chapter 10 and COD: Chapter 4

Quad Pod Presentations on SC: Chapter 5 and GLFS: Chapter 5; Summary Reading Report Due on ITJ: Chapter 11 and COD: Chapter 5

Quad Pod Presentations on SC: Chapter 6 and GLFS: Chapter 6; Summary Reading Report Due on "Sabbath/Sabbathkeeping" Handouts

Quad Pod Presentations on SC: Chapter 7 and GLFS: Chapter 7; Summary Reading Report Due on COD: Chapters 6-7

Quad Pod Presentations on SC: Chapter 8 and GLFS: Chapter 8; Summary Reading Report Due on COD: Chapters 8-9

Quad Pod Presentations on SC: Chapter 9 and GLFS: Chapter 9; Summary Reading Report Due on COD: Chapters 10-11

Quad Pod Presentations - SC: Chapter 10 \& GLFS: Chapter 10; Summary

Reading Report Due on COD: Chapters 12-13

Quad Pod Presentations - SC: Chapter 11 \& GLFS: Chapter 11; Summary

Reading Report Due on ITJ: Chapters 12-13

Quad Pod Presentations - SC: Chapter 12 \&GLFS: Chapter 12; Summary

Reading Report Due on ITJ: Chapter 8

Quad Pod Presentations - SC: Chapter 13 \& GLFS: Chapter 13; and "POST-TEST" 


\section{APPENDIX B \\ RETREAT MATERIALS \\ - Retreat Outline/Agenda}

- Handout 1 - "Perusing the Past" (Isaiah 49:1-7)

- Handout 2 - "Pondering the Present" (Psalm 139)

- Handout 3 - "Savoring the Sabbath" (Psalm 92)

- Handout 4 - "Facing the Future" (Isaiah 55)

- Retreat Evaluation Form 


\section{OAKWOOD UNIVERSITY DEPARTMENT OF RELIGION \& THEOLOGY \\ RP131: Spiritual Formation Retreat Outline/Agenda \\ March 13-15, 2009}

\section{Purposes of the Retreat}

1. Take time for examination of past spiritual experiences.

2. Take time for examination of present standing with God.

3. Let God help you envision the future.

4. Let God help you discover particular area where you need to grow.

$$
\text { FRIDAY }
$$

$\begin{array}{ll}\text { 2:00 - 2:30 p.m. } & \text { Load bus in front of Moseley Complex } \\ \text { 2:30 p.m. } & \text { Leave campus from Moseley Complex } \\ \text { 4:30 p.m. } & \text { Arrive at Camp Sumatanga } \\ \text { 4:30 - 5:30 p.m. } & \text { Check-in and Set-up } \\ \text { 5:30 - 6:30 p.m. } & \text { Dinner } \\ \text { 6:30 - 7:15 p.m. } & \text { PRAISE AND WORSHIP } \\ \text { 7:15 - 7:30 p.m. } & \text { PRAYERS OF ADORATION } \\ \text { 7:30 - 8:15 p.m. } & \text { Formative Fellowship } \\ \text { 8:15 - 9:00 p.m. } & \text { "Perusing the Past" (Isaiah 49:1-7) - Solitude/ journaling } \\ \text { 9:00 - 9:45 p.m. } & \text { Small Group Discussion 1 - Sharing on the past } \\ \text { 9:45 - 10:00 p.m. } & \text { Plenary Session } \\ \text { 10:00 - 11:00 p.m. } & \text { Free Time } \\ \text { 11:00 p.m. - 6:30 a.m. } & \text { Q U I E T T I M E }\end{array}$




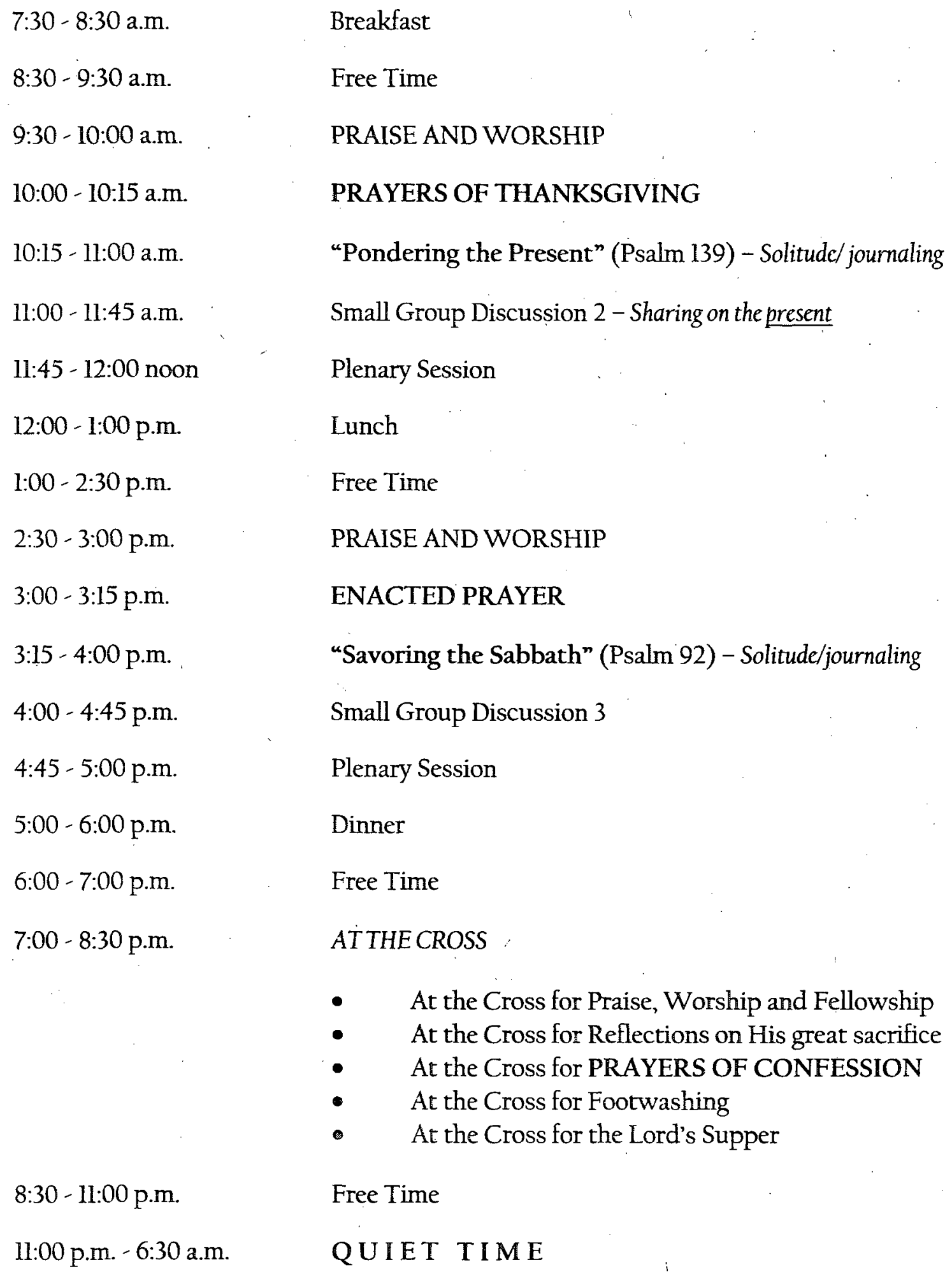


7:30 - 8:30 a.m.

8:30 - 9:30 a.m.

9:30 - 10:00 a.m.

10:00 - 10:15 a.m.

10:15 - 11:00 a.m.

11:00 - 11:45 a.m.

$11: 45$ - 12:00 noon

12:00 - 1:00 p.m.

l:00 p.m.
Breakfast

Free Time

PRAISE AND WORSHIP

\section{PRAYERS OF SUPPLICATION}

"Facing the Future" (Isaiah 55) - Solitude/journaling

Small group discussion on the future

Plenary Session

Lunch

Leave Camp Sumatanga for Oakwood University 


\section{OAKWOOD UNIVERSITY \\ DEPARTMENT OF RELIGION \& THEOLOCY \\ RP131: Spiritual Formation Retreat}

"GOD'S HAND IN MY LIFE"

"Perusing the Past"

1. Read carefully Isaiah $49: 1-7$.

2. Then. Who is the one called in verse 3 "my servant" and "Israel" (literally "God strives")? Note carefully what is said here about this servant's past. In what ways has God worked for the servant in the past? Has this servant always been what $s /$ he should have been (note verse 4 )? Write down all the ways God has acted in the history of His servant.

3. Now. Can you identity with the servant? Did God call you from the womb and name your name (verse 1)? Have you ever "labored in vain" or "spent your strength for nothing" (verse 4 RSV)? Has God worked in your past? Sit quietly, perhaps with eyes closed, and recall your past pilgrimage. Reenter your past and trace those key points where God has acted for you. Recall even those times when you weren't sure where God was. Write down as much as you can of your personal specific story of God's work in your past.

"We have nothing to fear for the future, except as we shall forget the way the Lord has led us, and His teaching in our past history." Life Sketches, page 196 


\section{OAKWOOD UNIVERSITY \\ DEPARTMENT OF RELICION \& THEOLOCY \\ RP131: Spiritual Formation Retreat}

"COD'S HAND IN MY LIFE"

"Pondering the Present"

1. Read thoughtfully Psalm 139:1-24.

2. Then. Make a list of all the things the Psalmist says God knows about his present life. What does this lead him to think and do? Ponder the awesomeness of God's knowledge. How do you think the realization of God's knowing all this affected the Psalmist's present life and decisions?

3. Now. Sensing that God knows all about us, what do you think would be His evaluation of your present life? In this time of reflection and quiet, picture yourself in God's presence. Knowing that He knows all about you, yet loves you tremendously, honestly face your present. Record in writing what you think is His evaluation as well as your evaluation of your present. Where are you now?

4. Write down three things that you think God would like you to work on in your spiritual life this coming year. One good way to do this is to think of one thing directly related to your devotional life or relationship with God. Write down a second thing related to human relationships - a spouse, child, parent, friend, sibling, etc. Lastly write down something that has to do with your relation to the physical realm - diet, exercise, addictions, time, etc. 


\section{OAKIWOOD UNIVERSITY \\ DEPARTMENT OF RELIGION \& THEOLOCY \\ RP131: Spiritual Formation Retreat}

\section{"GOD'S HAND IN MY LIFE" \\ "Savoring the Sabbath"}

1. Read joyfully Psalm 92 - the only psalm expressly connected with the Sabbath.

2. Then. Explain in writing why it is a good idea (a) "to praise the LORD;"

(b) "to make music to His name;" (c) "to proclaim His love in the morning;" and

(d) "to proclaim His faithfulness at night." List what deeds of the LORD make you glad and what works of His hands cause you to sing for joy. To what extent does the Sabbath provide you with greater opportunity and ability to recognize and appreciate the greatness of the LORD's works and the depth of His thoughts? How does the Sabbath remind you that the LORD is exalted forever? What promise in the final third of this psalm (verses 11-15) is most precious to you and why?

3. Now. Compare Ezekiel 20:12 and Ezekiel 20:20. What is the same in these verses? What is different in these verses? What is the significance of both? Jesus said, "The Sabbath is made for humans and not humans for the Sabbath. So the Son of Man is Lord even of the Sabbath." (Mark 2:27-28). In other words, "the Sabbath tells us that there is a time to close the door of our homes and our minds to the clutter and noise of the world and to come into the presence of the ONE Who made us and Who knows what we need." Just savor the reality of His Special Presence on His special day for being with you.

"The Sabbath is holy because God fills it with His Presence. Therefore the Sabbath is not just a day, but a Person! In a special way during its hours God gives not only rest and power but, most importantly, Himself. 'The Sabbath is the most precious present humankind has received from the treasure house of God.' It is so because the gift contains the Giver!" A Love Song for the Sabbath, page 29 


\section{OAKWOOD UNIVERSITY \\ DEPARTMENT OF RELIGION \& THEOLOGY \\ RP131: Spiritual Formation Retreat}

"GOD'S HAND IN MY LIFE"

"Facing the Future"

1. Read carefully Isaiah 55 .

2. Then. For the Israelites who seek the Lord, what are all things specifically promised for the future (note especially verses 10-13)? Look again at the promises found in the first Isaiah passage we studied and note especially Isaiah 49:6-7. Write down the promises from these two passages in a list and think about them. Try to sense how a discouraged Israelite would have felt when s/he read them.

3. Now. Relax in quietness in God's presence. Meditate on some of the things you'd like to see God do in your future. Claim some of these promises for yourself. Don't worry about impure motives - God can help you deal with these later. Allow yourself to dream what might take place by God's power in your life. What would you like to see happen? Write down your hopes, dreams, and plans for your future.

"If the future looks somewhat clouded, hope on, believe on. The cloud will disappear, and light shine again." Testimonies, Volume 1, page 663 


\section{OAKWOOD UNIVERSITY \\ DEPARTMENT OF RELIGION \& THEOLOGY \\ RP131: SPIRITUAL FORMATION}

\section{Spiritual Retreat Evaluation}

\begin{tabular}{|c|c|c|c|c|c|c|}
\hline & $\underline{\mathrm{Ha}}$ & Harmful & $\begin{array}{l}\text { Not } \\
\text { Helpful }\end{array}$ & Neutral & Helpful & $\begin{array}{l}\text { Very } \\
\text { Helpful }\end{array}$ \\
\hline & the Oakwood University experience. & 1 & 2. & 3 & 4 & 5 \\
\hline 2. & To what extent was the retreat spiritually beneficial? & l? 1 & 2 & 3 & 4 & 5 \\
\hline 3. & How beneficial was the meditation on Scripture? & 1 & 2 & 3 & 4 & 5 \\
\hline 4. & How beneficial was the time in solitude/silence? & 1 & 2 & 3 & 4 & 5 \\
\hline 5. & How beneficial was the formative fellowship game? & 1 & 2 & 3 & 4 & 5 \\
\hline 6. & How beneficial was the small group experience? & 1 & 2 & 3 & 4 & 5 \\
\hline 7. & How beneficial was the Communion experience? & 1 & 2 & 3 & 4 & 5 \\
\hline
\end{tabular}

8. What did you learn about:
A. God
B. Yourself
C. Others

9. Describe the most significant part of the retreat for you.

10. What suggestions do you have for the improvement of future retreats? 
APPENDIX C

\section{STUDENT REFLECTION PAPER REFERENCES TO}

SABBATH/SABBATHKEEPING

\section{African American Male}

04/22/09

Spiritual Formation

Prof. Kwesi

Reflection paper

This Semester I have learned a lot from the spiritual formation class, but more importantly I have learned a lot about my relationship with God. In the beginning of the Semester I thought of the weekly reports as a simple task that needed minimal effort to be complete. However, they proved to be an admiral opponent. I found myself attempting to squeeze small amounts of time to get the requirements complete, to no avail. Then I realized how little time I spent in prayer, and with God, So I set aside a set to time and place for my devotions. I found it rough at first but I reminded myself I need this for my class. After a while I began to fell that although my actions were commendable, my purpose was wrong. I came to the conclusion that the point of the reports were not just to have a devotional and complete an assignment, but to keep us un line with our purpose and goal for the class; spiritual formation. By asking us to share with you our experience each week, you were attempting to keep us on track.

As I reflect on my experience this Semester, 1 find it impossible to neglect the retreat. As time neared for the trip I began to wonder how I would ever survive. Because I am mostly silent and seemingly shy my first concern was whom would I 
talk to for the entire trip. Of course I had a few casual friends from both sections; I didn't think that I would socialize with anybody. Second came my concern about losing signal for an entire weekend, and of all the weekends that particular weekend. That weekend I was expecting to receive my passport from the government. This "event" was important to me because I needed my passport to go to my grandmother's funeral and without it I would have to miss it. However, once I lost signal, 1 prayed for peace and like my cell phone signal had gone, so did my worries and anxiety. When it came time to leave I felt the same way I did going there but for a different reason. When we left Oakwood I didn't want to go on the trip. When it was time to go I didn't want to leave the camp grounds. Most people didn't want to leave because they didn't want to return to work. I didn't want to leave because I spent the best Sabbath of my life there and more importantly I spent it with God.

Overall this experience for me has been one I will always remember, and I've promised myself although I might not be taking the class spiritual formation, I will still strive to practice what I've learned. 
African American Female

Dr. Kwesi

Spiritual Formation

19 April 2009

A Reflection on my spiritual formation

There comes a time when you've been a Christian for so long that you no longer view yourself as a sinner. You don't curse, party, drink, or steal so you place yourself on a pedestal and feel that there are no changes that have to be made. It is not until you are interrupted, that you realize that becoming like Christ is not only based upon your actions, but also your heart and your mind. This is the realization I came to when I entered my Spiritual Formation class. This class has helped me to realize how small I am and how big God is, to trust God and give Him full control, and to understand His gift tome: the Sabbath.

It was in quiet of Camp Sumatanga that I realized how small I was. I was sitting on the porch, observing nature and pondering on the assignment question about how God has led you in the past. Somehow I felt like a spectator of my life and I saw how God's hand moved throughout my life. I began to feel so overwhelmed because every success, every failure, every good situation, and every hurtful situation God was there the entire time. At that moment I understood why David said, "What is man that thou art mindful of him?" In my dark moments, I cursed God as if He was on my level, yet He still comforted me when I wanted nothing to do with Him. After I had thought about my life, I saw an ant and I realized that God is so big that I look smaller than an ant yet His love is so much greater than the size difference. This gave me 
hope and helped me to decide that from now on my main goal would be to become more like Christ.

After that realization, I was on the road to relinquishing control of my life. This by far was, and still is, the hardest stage in my spiritual walk. I've been so used to working hard, being organized academically, and doing things ahead of time to make sure nothing goes wrong that when God sent circumstances that were beyond my control, I felt so hopeless. It was like he closed ever self help door and left His open, yet I still searched for other doors and tried to open doors that I knew were closed. It wasn't until I read the Discipline of Submission, that I realized that this problem had to be overcome, with His help, so that I could walk in accordance to God's will, not my own.

Spiritual Formation has also shown me how intimate God wants to be with me on His day. Growing up your taught that this is the day that you can't do certain things, there seemed to be all these restrictions and no freedom. At the retreat, Ms. Allen told us to picture God as eternity high and wide then view time as a slip of paper and our stories on that paper. In my mind my stories was a dot on the paper, then she said that on the Sabbath God confines himself to that dot so he can take care of our issues. When I heard that it literally blew my mind, it was a new and fresh concept that included freedom and joy in Christ. It turned my mindset from wishing the Sabbath was over to being anxious for the Sabbath to come so I can experience that intimacy.

This class will forever be close to my heart because it has trully taken my spiritual life to the next level. Every day in this class has been like a seed being 
planted and now God is waiting for those seeds to take fruit. Though this Semester had many spiritual growing pains, I am still thankful for them because I am now in the process of being conformed to the image of Christ for the sake of others. Thank you Dr. Kwesi for your dedication, I know you will have a star on your crown because you have brought me closer to Christ. 
African American Female

Spiritual Formation

Professor Kwesi

21 April 2009

This spiritual formation class has opened my eyes to many things in my life that I never noticed before or they just made them clearer. 1 have to say that the thing that most impacted my spiritual growth is reading Celebration of Discipline, Invitation to a Journey, More Jesus Less Religion, and In the Name of Jesus. These books opened my eyes to what I was doing right in my walk, what I needed to improve on, and what I needed to start doing. Celebration of Discipline and In the Name of Jesus were the most impacting. Celebration of Discipline just made me realize how much God loves us and how much He has given us so that we can praise Him. The main sections that impacted me the most Discipline of Solitude, Submission, Confession, Worship, and Celebration. Solitude because in tend to be busy all the time and for me to be able to just shut down and say I'm turning of the world and just focusing on my Jesus is a huge sign of growth. I've gotten to the point where I'm in church and I just shut down and get into this place of silence and "solitude" where I can't do anything but listen to my Father and I could never do that before. Then there's worship that section was incredible to readjust how we were created to worship. I heard it said before but now I understand more and more that we worship whether we want to or not we the only thing we do choose is who we worship. Choosing not to worship Christ in essence is saying I will worship That Other Guy. A sentence from the chapter that has stuck with me is where he says, "We must have "wineskins" that will embody our experience of worship." It just validates 
what Jesus said in Luke 5:33-39 "you cannot put new wine in old wineskins." In the Name of Jesus showed me just how unselfish I have to be as a woman going into the work of my Father. The author was a well respected theologian who was a chair person at Harvard or Yale and he gave it all up because the Lord called him to humility. He (Henri JM Nouwen) has a chapter talking about feeding the sheep of our master. Nouwen says "The mystery of ministry is that we have been chosen to make our own limited and very conditional love the gateway for the unlimited and unconditional love of God." After reading this book my whole view of how I can live life has changed for the simple fact that I have a responsibility I can't just do what I want because I have to be a reflection of God.

This class has taught me a lot about myself. It has shown me how much God is working on me where He's brought me from and the amazing places He is going to take me to. It has also shown me how good a job my parents did in raising me. They trained me up in the way I should go (Proverbs 22:6). I say that because they raised me according to scripture that's why I did the discipline's that I was already doing because they instilled in me to be obedient to God. By being obedient, sort of by default, these disciplines where just naturally practiced.

There are entirely too many things that I learned about God. The thing that blew my mind was when we were on the retreat and Dr. Allen said the first gift God gave us was the Sabbath. The day after man was created God designed it so that we rest He never wanted us to work on that day. Now I understand why it say's in Mark 2: 27 "The Sabbath was made for man, not man for the Sabbath." I've also come to the understanding that worship, praise, and adoration are all a gift from God for us to 
give them back to Him. I'm still trying to rap my mind around all of that. What I've learned about God is that $\mathrm{He}$ is just amazing. It's hurting my brain to find a word in the English language that can even come close to relay how amazing this God I serve is.

Thank you so much for teaching this class and giving it to us straight. This class has been a tremendous blessing to my life. Also thank you for being an example of a woman who is following the will of God despite the many obstacles that I'm sure you had to face. God bless you Professor. Shalom. 
African American Male

April 22, 2009

Spiritual Formation

Prof. Kwesi

\section{Reflection Paper}

As I look at my progress from the being of this new 2009 year, I've see that I have made improvements from last Semester but I know that I am still far from where I should be or at least where me and God should be. I've taken this class as a second chance to be right with Christ spiritually and to discern His will for my life. Although I didn't accomplish this goal in all it's entirety I, nonetheless, feel that the seed was planted and is a bit more deeply rooted than the first batch that was quick taken up by the ravens of life. This Semester I seemed to be still reticent in my conversations with God and lacked, what I think is, true authenticity in my prayers. However I feel that I am getting the gist of what is expected and with the help of many people, sermons, class readings on the Disciplines and experiences I've been able to pin some of the primary hindrances and am pushing to let go of will and submit to the Holy Spirit so that these blockades are removed. I've also in the course of this Semester had conceded that everyone has a spiritual age likened to a physical age; A sense of spiritual maturity as same as mental maturity. With that say, I see that although on the externally, many people have looked up to me and classified me as spiritually mature, I am far from the maturity that people assume me to be. Nonetheless, I've feel that I have grown a bit more from the stage that I feel I have been in since my younger years. I have been able to understand why certain things have happened and learned to accept, receive and believe, through and in faith that all things will work together for the good of those who love the Lord. I have learned more 
at this Sumatunga mountain experience then in the last that I went to last Semester, not saying that there was no effect on last years retreat. The experience this year, in a way, had more meaning. I truly felt that the Sabbath experience was like none other that I've experience. It changed my perspective of what I truly a "good Sabbath" and a "Godcentered great" Sabbath. The song "how good it is to thank the Lord" touched me not only in words but in tune. I felt a sobered sense of calm at the last supper this time around than I did the last time. One think that I felt this year was a sense of spiritual tears. I felt that the ideals, the traditions, the lifestyles that I grew up seeing was being torn apart and being reconstructed right before my eyes. I was very uncomfortable to come to grips with this radical change in my life but to know that soon I will be in the image of Christ not by my own table but in his makes the spiritual journey and experience all the more meaningful. I also was exposed again to my true self. I have seen that my will is not capable of accomplishing anything. I've seen yet again, that I am prone to procrastinate and set times for other things than to speak with my Father. I've also was faced with the ultimate decision of whether I accept this part of me or am I willing to allow the Holy spirit to convict, change, and remake me into the image of Christ. Spiritual formation has brought out to light the things I've tried so hard to keep under wraps and work on myself. The class has gotten me to the point of giving up trying to do things on my own power and to try something else. Although, I am fully aware of who to put my trust in. the dilemma for has been to push myself to Christ all the more closer to be touched by him. I've been given the tools in the Disciplines. Now it is all about putting this tools in to practice; not looking for help to get me out of trouble but for strength and faith touch Jesus and receive change in my life to bless other. 
African American Male

April 21,2009

Spiritual Formation

Professor Ifeoma I. Kwesi

Spiritual Formation Reflection Paper

When I first met Ms. Kwesi, I was at Oakwood's 2007 College Days. Ms.

Kwesi was the instructor who briefed the prospective theology students about the challenges and events that lay ahead if they choose to proceed with entering the program. Ms. Kwesi discussed how she received her calling and also talked about the class in which every theology major freshman had to take in their first year which was spiritual formation. Never had I seen such a strong woman for Christ. This first encounter with her truly left a lasting impression in my mind. This Semester was the first Semester that I attended Oakwood University and on my quest to find out if I should enroll into the Theology program, James Doggette suggested that I take , spiritual formation to help out with my decision. There, I found out not only about this woman who seemed so strong and so focused but I found out about the traits and tendencies of myself, the lives and ambitions of others around me and most of all, I gain a new grasp on a relationship that I had been lacking almost ever since I became a Christian, a relationship with the living God.

When asked in what ways in which I have grown spiritually, I think mostly about my renewed relationship with God. Before I came to Oakwood I was a guy who had broken up with his girlfriend because I had began to depend on her more that God himself. I prayed only when she prayed and studied the bible only when the idea arose in her head. Coming to Oakwood, I was away from that but I didn't pray as if I was 
talking to my father. I didn't rest on his promises like I was resting in his arms. I didn't have a relationship with him and I really didn't notice the seriousness of my condition. The spiritual discipline reports that were required from us at the beginning of each week really woke me up spiritually because it was by struggling with making the time with God every week just to spend three hours with him that I realized that Satan knows the potential of a genuine relationship with God and he is on the attack to stop it by any means.

I also realized that so many of God's ministers go before God's flock to feed them by way of preaching without having any power because of the lack of time that they've had with God. Some might have lied on all of their spiritual disciplines reports, some might have felt forced into spending time with Jesus and began to spend time with him only because of a grade but I began to really commit myself to developing a real devotional life with Jesus. It took some time and wrestling but eventually I was able to do it and I have found out that it is true that when you draw near to God, He will draw near to you. My take on the Sabbath has completely changed ever since the spiritual retreat. It's has truly become the place where I realize all the provisions that God has made just to spend some time with me. I now light candles (When I am not living on campus!) and I also play songs to bring in that day so that it can feel more personal.

This Semester I found out so much about myself. For one, I found out that I didn't tend to think about anyone else but myself. I was so used to finishing work by myself but when Ms. Kwesi placed the class into Quad Pods, It was totally out of my comfort zone. In that group I had to learn how to be a subordinate which was so hard 
for me because back at home I'm always used to being a leader. I also learned about leadership but I found that in order to be a leader for people you have to learn more about them personally. At the spiritual retreat I thoroughly blessed by hearing the testimonies and the experiences of my Quad Pod members which empowered me and encouraged me with the fact that Jesus can really change hearts from any road of life. I thank Michael, Jonathon and Esperanza for divulging their powerful testimonies and they will forever remember them.

What have I learned about God? Through this Semester I have learned that simply put, God is love with me. He longs for us to have talk to him. It might sound redundant at first but in this class I've come to realize what this truly means. It means that the God of the universe as holy and as perfect as he is just wants to commune with us no matter what problems that we have. If we come to him sincerely, with our addictions and our habits, he has the power to erase them from our lives if we just make it our business to spend time with him. I also have learned that God really restores. He has rejuvenated a once dead and dry devotional life and he continues to work in my life even as I type these words. I challenge anyone who wants that relationship with God. Who wants to cease the habitual sins in their life that are contrary to his will. Just spend time with Him and talk with Him. Meditate on Him and study about Him. It can be as little as 15 minutes a day because that's all God needs to stir things up in your life. Give him the time and he will give you the freedom. 
African American Male

RP131MW 9-9:50

$3 / 23 / 09$

\section{Reflection}

The experience I gained from the spiritual formation course was much unexpected. I can say. without a doubt that I have grown spiritually. By the knowledge that I have received God has confirmed a lot to me about myself. I also have learned two hands full worth of the Creator. .

To begin, I start off by saying that I have grown a lot from this course. My dedication to the relationship that God has called me to has gotten serious. I realize more and more that God wants to be in every single part of my life and doesn't want to be left out for a second. He is my spiritual ship and anchor; He keeps me afloat and steady. By the power of the Holy Spirit it has been brought to my attention that there is nothing that I can do right so I need to stop trying.

As a matter of fact, it is the Spirit that changes my prayers and puts God's law in my heart so that I can follow it (Roman 8:26, Heb 8:10). The Holy Spirit has revealed to me by His word that my spiritual growth relies on Him. All I need to do is stay connected to the vine and I will be able to grow and bear fruit (John 15:5). Understanding a little bit more of what Christ asks of me has made my walk with Him much easier. All God wants from me is obedience and unwavering faith. I have been hearing for years that Christ has done it all but I have never accepted that saying until this course.

Furthermore, I have learned a lot about myself this Semester. I see that when it 
comes to the major test's I am strong enough to hold on to Christ until the end but when it comes to the small test's I'm shaky in trusting Him. Another thing that has come to my attention about myself is that I'm judgmental. I have a hard time realizing that the same way God has brought me out of Egypt is the same way He will bring others out also. The majority of the time I condemn the sinner and not the sin. I have learned that the spiritual disciplines are just an outward manifestation to what's taking place inside of me.

The Spirit of God has put a mirror in front of my life and I see myself for who I really am. I got to a point in my life that I didn't know what to ask God for forgiveness for but this course has made me make a 180 degree turn from that mentality. Also, God has shown me that He has blessed me with wisdom but that doesn't negate the fact that I have to surrender to Him daily. At times I catch myself living on wisdom and the knowledge of God and not devoting my life to Him every day and night.

Moreover, I have learned many things about God. My knowledge of God was pretty good before this course but there were certain things that I knew before that was illuminated in this course. Above all things I have come to see that God is not only a God of love but He is a personal God. Father, Son and Holy Ghost work as one every time and all the time. No One is greater than the other. What came to my attention that's so beautiful to me about my Lord is that He steps out of eternity for a day to get closer to me; "Sabbath is not a day but a person."

I have learned that God sets up things in ways for my benefit and not His. 
Everything that $\mathrm{He}$ does is for my best interest and to prove that $\mathrm{He}$ is just. I see that the way God deals with us all is different but at the end of the day if we submit to Him we will all be lead to the same destination. What strikes me the most about God . is that He will never tell me to do something He wouldn't do, He would never tell me to go somewhere He would not go and if He doesn't I should trust Him anyhow. The fact that God is my Father, Brother, Savior and Farmer shows me that Christ is the center of all things so I should allow Him to be the center of my life.

To conclude, this spiritual formation course has allowed me to grow in Christ, learn more about myself and God. The formation of the characters of future ministers is important and it's even more important that the professor that teaches the course is sincere about their relationship with Christ, and that my professor is. 
African American Male

Professor Kwesi

$4 / 22 / 09$

\section{Reflection Paper}

I'll never forget the day God called me to the ministry. Unaware of the expectations and responsibilities of leadership, I was overly zealous and bubbling over with excitement as I contemplated the prospect of ministry. In the process of my transformation God revealed to me the seriousness of the work he was preparing me for. I found it very difficult to accept this calling from God after coming to the realization of my inadequacies.

As the days morphed into months and the months morphed into years, I found myself at Oakwood University campus by divine appointment. Relocating from Saint Louis to Huntsville was not easy at all for me considering being newly engaged and very comfortable. The very first class I attended at Oakwood University was my Spiritual Formation class which was taught by one of my favorite teachers, Professor Kwesi. Growing spiritually, learning more about myself, and learning more about God is a spiritual experience I am proud to have been apart of.

One of the ways I've grown spiritually is through a consistent prayer life. My prayer life has not been as strong as it should have been in past time. However, by practicing the spiritual disciplines assigned by Professor Kwesi whipped me into shape fast. I spent three hours a week minimum interceding on behalf of my professors, family members, friends, leaders, and self. This practice has brought me closer to Christ teaching me that where that is much prayer, there is much power. The more I talked to Christ the more I put on his character. 
One of the things I've learned about myself this Semester was the "self that was in me." It was not until I began to spend quality time with Christ in prayer, that he began to show me how much of me was still in the way. I learned the less of me means more of the Holy Spirit filled me. Because of my understanding of selflessness, I better understood the definition of Spiritual Formation. Spiritual Formation is conforming to the image of God for the sake of others. I learned that this process is needed because by conforming to the image God for the sake of others takes cleansing and emptying out of self.

Experiencing the Spiritual Retreat taught me that I should never place God inside of a box. I became so accustomed to Sabbath worship in the sanctuary; it blew my mind the way I communed with Him so intimately at the retreat. By working in my Quad Pod I learned that God is equally a corporate God as he is an individual God. Socializing and putting our heads together before presentations opened my eyes to a deeper understanding of where there is two or three gathered in Christ's name there he is in the midst!

I also enjoyed the weekly reports. I've never read as much in one class as I did in Spiritual Formation. It was through the weekly reports that God revealed to me the importance of discipline. He revealed to me that it is His desire for His people to be disciplined so that they can be fully equip for practical and spiritual ministerial responsibility. I learned a lot in Professors Kwesi's class Spiritual Formation; and if I had to describe everything I learned in one sentence with encompassing them all, then I would say "The main thing is to keep the Main thing the main thing." 
African American Male

Spiritual Formation

Reflection Paper

April 22, 2009

This Semester has been interesting. I have learned a lot. I have experienced a lot as well. Consequently, I have gained new insights. Moreover, I see some issues differently. The purpose of this paper is to discuss my spiritual experience this Semester. In order to do that, I will address three issues. They are as follows: The ways I have grown spiritually, what I have learned about myself, and what I have learned about God.

I will begin with the ways I have grown spiritually. This is an interesting question. On the surface, the answer is easy. I have read my Bible more than I had in a long time. As a matter of fact, I did more reading than I have ever done. Yet, part of me knows that this question is asking me to dig deeper. That is what I intend to do. For example, I have come to a new perspective on the Sabbath. I need to explain this.

One day, I was driving home. I was thinking. This Semester, I have decided to take basketball up again. Therefore, I have been working to get back in shape. However, my efforts have been unclear. More specifically, I have been telling myself; I just want to get better. Yet, the fact that I want to get better creates a question. What am I getting better for? That night in the car, I asked myself why I do not have a goal. From there I really began to think. I asked an obvious question. Why is my goal not to play professionally? I thought about the answers. There were many reasons not to pursue professional basketball. For 
instance, I am twenty four. I have not played seriously for years. I am extremely out of shape. I have a family to provide for. However, all of these obstacles seem surmountable.

Then I started to think about the conflict between playing professionally, and Sabbath keeping. I felt like that was the most legitimate obstacle. Then I had to figure out what I was saying. I was saying that I won't pursue what I love because of the Sabbath. Then I realized two things. First of all, that was wrong. Secondly, there was a problem with my idea of the Sabbath. I realized that I could not give up that dream for that reason. I look at it like this. It is like when people get married because they are expecting a child. They are doing it out of obligation. They are not doing it because of love. I concluded that if that is what I was doing I may as well pursue basketball. I would only be keeping the Sabbath out of obligation. It would not be because I love it. Therefore, at some point, I would probably end up resenting my decision. That is when I realized that I could not give up basketball for the Sabbath in that manner. The Sabbath could not be an obligation. It had to be something I love. Thus, I would be giving up something I love for something I love more. As a consequence, there would be no regrets.

I did learn something's about me. First of all, I learned that I like learning. It surprises me the things I have retained. For instance, I can remember sharing some of the things I have learned. I talk to my friends and family about things I got from class. On the other hand, I have learned about perseverance. I have learned that success does not always happen the way people want. In other words, I want to get to Heaven, but it's not easy. There are many obstacles. In 
addition, I mess up a lot. Consequently, I get discouraged. However, I believe that the worst thing I can do is give up. I realize something. I cannot get myself into Heaven anyway. Therefore, I do not trust my own merits. I am trusting Jesus'. That suggests that there is always hope. This hope would not be there if it was about me. However, if I give up there is no hope. That is because of this fact. Essentially, to say that I give up is to say that I have no faith.

I also learned something about God. God forgives sin. The funny thing is I already knew the information. Yet, sometimes there is a difference between knowing and understanding. For example, I have learned about God. I learned that he forgives sins. If we confess our sins he forgives them. I was taught that as a child. However, I just began understanding it. At some point this Semester, I learned that God does not simply forgive sins. He forgets them. In other words, peoples past sins are not only forgiven. They no longer exist. I knew this.

Nonetheless, it was like a new concept. When I grasped it, the information had such an impact.

It made me think about doubt, and guilt. I remember doing devotion on doubt. It is an amazing situation. The truth is that when I feel guilt, I am the only one holding on to the sin. Thus, doubt is like an imaginary prison. It holds me captive. Yet, it does not really exist. As a result, I cannot understand the reality. God is not holding on to a sin. He is not waiting to bring it up when I mess up. When he says it is done, it is just that. Thus, the problem is not with him. It is with my ability to accept what he says. 
In conclusion, this was a great Semester. I grew spiritually. I learned about myself. I also learned about God. Spiritually, I have a new outlook on the, Sabbath. In addition, I learned that I have to persevere in life. The worst thing anybody can do is quit. Furthermore, I learned that God does what he says. He forgives sins, He also forgets them. It is important to grasp that. That is because the reality of it is beautiful. 


\title{
APPENDIX D
}

\section{STUDENT RESOURCE FILE REFERENCES TO}

\author{
SABBATH/SABBATHKEEPING
}

\section{African American Male}

\section{Sabbath}

Resource \#I-"Cornmandments Under Attack" Pamphlet

This pamphlet reminds me that God's law, and his truth in general is questioned, and altered. As Seventh-Day-Adventist we worship on the Sabbath of his creation, the day he made Holy. The account of Cain and Abel comes to mind, because Cain brought to the alter what he felt was Holy and acceptable, and wanted to tell God to accept it. in relation to that, there are people who know God's Sabbath, and yet they stiff have their worship on a day that wasn't set aside as sacred and Holy. As humans, we tend to want to tell God what we want to do with his law, instead of simply honoring his law. He doesn't force us to follow his law and keep his Sabbath, but out of respect for his commands, and our love for him, we reverence the Sabbath and keep it.

Resource \#2-Candle

1 included the candle in my file, because lighting candles on the Sabbath helps me to enter a meditative spirit. It fosters an environment of rest, and peace. Lighting a candle also helps me to forget about the hustle and bustle of the week, forget about T.V. and other worldly things, and just focus on Christ. 
African American Male

Spiritual Formation

$4 / 29 / 09$

\section{CANDIE LTGHT}

I am going to introduce the lighting of seven candles in my home on Friday evenings to welcome the Sabbath and teach my family Shabbath shalom song. The candle also reminds me that Jesus is the light of the world and in him no darkness can be found, he has also transported me from darkness into his marvelous light, now I walk by faith and not by sight. As a Christian I also remember that I am to be Sight to other people by loving, sharing, caring and encouraging them anyway possible for the sake of the gospel and their soul salvation. 


\section{Sabbath}

A specially wrapped gift Is represents that Sabbath to me. A gift is usually something as a toke of appreciation and love. A gift lets you know that that someone was thinking about you. It could be your birthday, Christmas or any other special occasion I see the Sabbath as God special gift to me because he set it aside and sanctified it. It reminds of how special that I am to God and how he really desire time with me. It gives me time to divert all rny focus on him.

African American Female

\section{Sabbath}

I chose a highlighter to represent the Sabbath. The basic use for a highlightèr is to highlight important information to see you can be familiar with it. I really have grown to look forward to the Sabbath. The Sabbath is the highlight of my week. No matter what is going on during the week I know that my time with God is soon to come. 


\section{Personal Time with God}

This is the Bible I spend time reading every Sabbath. The Sabbath provides me with more times to spend in communion with my heavenly father. It gives me a taste of what heaven will be like: no worries of the week, complete surrender to God. I have more time to spend in devotion with Him without having to worry about what time it is, and if I'm late for class or for work.

African American Female

\section{Sabbath}

\section{Fellowship with others}

This is a picture of my friends on a Saturday morning on our way to church. The Sabbath gives me a change to get together Ivith my brothers and sisters in Christ who shares the same faith together with me. The church gives me a chance to share my testimonies, prayer requests, and also be liable for one another. The Sabbath also provides me with an opportunity to visits those who are sick and homeless. Church's family helps me to keep the Sabbath holy by praying for me, check up on me, and visits me when I'm sick or don't come to church. 
African American Female

\section{Sabbath}

John 3:16- This is my favorite verse. It is my favorite because is reminds me of God's love, his sacrifice, and his gift to me. How it helps me reverence the Sabbath? it sets my focus on God and why I believe in him and why I want to have eternal life.

Church-1 love church 1 love the opportunity that 1 have weekly to spend time in worship and fellowship. Although sometimes people within the church can make church an uninviting experience for the most part church is a great way to be Sifted up and refreshed for the future. The happiest 1 have from spending time in God's house with others and the joy 1 gain from having an intimate moment of praise with God is priceless. For me Church is a great way to continue growing in God's love amongst others. 
African American Male

My Spiritual Formation

This Semester was a Semester that I will never forget for as long as I am on this earth. Spiritual Formation opened up my eyes to things that I have never seen before in myself, my life, and my world around me. From the beginning, I felt a special kind of vibe/atmosphere in the class room that Dr. Kwesi created for us. Her devotions from the book "He Shall Be Called", to the discussions of "Invitation to a Journey," opened up senses of a very spirit lead imagination, Most professors only lecture Jesus, or their knowledge, but Dr. Kwesi allowed the Lord to lead her in her presentations to the point where it touched every student in the class room.

Now, every student in the class room I didn't know, or care to know (just to be honest), but one particular weekend every thought that I had toward that changed....for the best. Camp Sumatanga was the name of the place where my eyes saw my true character. The place where some of the closest friendships that I will ever have in life where formed. The place where my test started. It was there that I found out the true meaning of separation and solitude. I learned about Goods plan in my past, my present, and also in my future. And if that wasn't enough I found out that my view of the Sabbath was far off the path of where it should have been. Talk about growing from a boy to a man in God. I had true formation during communion. Its funny how when I was younger, and when I got baptized for that matter, I never got the true meaning of something so special. I thanked God for Dr. Kwesi's talent in retreats, man oh man what a blessing. A true mountain top experience is what I had that weekend.

I feel that I have grown from where I was in my spiritual walk with God. I'm not saying that everything has been smooth, because I have had my bad days. I am saying that I know how to trust in God, and I have kept and remembered a couple things to help keep my Spiritual Formation ever growing. Here are just a few... 
African American Female

The Sabbath has become something brand new, since the spiritual retreat. My spiritual formation family has been very encouraging in terms of going to church, and being each others prayer buddies. The Sabbath to me is the greatest gift other than life that God has given us. I liken the Sabbath to a charger, because our bodies were made to work, but also to rest and the Sabbath is like recharge day 


\section{MOVIE (NOAH AND THE GREAT FLOOD)}

This is a movie that my father gave me. I watch it on Sabbath and even other times because I love animation, and it doesn't pollute the truth. It's very straight-forward. Even' time I watch this one in particular though, especially lately, it makes think how times are very similar to the times back then. We're facing very strange developments, and ultimately we're going to see an end to these developments, just as Noah eventually did.

African American Male

\section{MOVIE (THE PASSION)}

I saw this at the theater when it first came out. There were some things I didn't like about it, but it was over all a good movie: I love how it doesn't make the story of Jesus look rosy. It shows that our savior actually went through torture on our behalf. I love this movie and watch it often on Sabbath with friends. 


\section{African American Female}

\section{Sabbath}

We were given a card that had as its cover, a picture of two dogs who were both visibly exhausted. Inside the caption read, "Is it Sabbath yet?!" Funny thing is, sometimes I feel like those poor dogs looked, completely worn out by assignments, friends, family, responsibility, and even ministry during the week. I don't think I have ever appreciated the Sabbath more than I do now, not that I am an Oakwood student. It amazes me to think, that God foresaw how man would exhaust himself all week, and saw it fit to create a Sabbath for them. Thus, this card is one of the best reminders that the Sabbath is a time for physical, emotional, and mental rest.

African American Female

Sabbath

The second item I chose was a vacation magnet from Florida. The scene is lovely, white sands, blue skies, and colorful umbrellas. Just looking at the picture evokes a sort of longing for that place that just seems so tranquil and relaxing. This is the attitude that I want to have about the Sabbath. God, in His divine wisdom, gave it to us once a week to appreciate. If it had been everyday; it would have been too common to appreciate. If it were once a year, it would have been too infrequent to enjoy. I want to view the Sabbath as my weekly vacation, and long for that tranquility and rest. 
African American Male

Spiritual Formation

$4 / 26 / 09$

Nature

I chose this picture of nature to express relaxation and rest on the Sabbath day.

When I was introduced to the Seventh Day Adventist faith I truly believed the Sabbath was burden and curse from God. As I matured in the faith I realized that the Sabbath is far from a burden and a curse. I learned that it is actually designed to relieve burdens and give rest to hard workers. This picture that I chose reminds me of relaxation and rest to contemplate on the goodness of my Lord and Savior Jesus Christ.

\section{African American Male}

Spiritual Formation

$4 / 26 / 09$

Family (Sabbath)

I chose a picture of my family because I used to believe that the Sabbath was only about God. As I matured in the faith I later discovered that the Sabbath was two-fold; fellowship with God and fellowship with mankind. I started spending time with my family instead of hanging out at the church all day neglecting my family at home. God revealed to me through this that Sabbath is more than what many people believe and that it was designed so that all can be in relationship with Him and each other. 
African American Male

Professor Ifeoma Kwesi

Final Exam/Resource File

\section{Sabbath}

One of the ways I view the Sabbath is like warm comfortable socks. The Sabbath is a day of rest; it is literally a day of rest. When I go to sleep I love feeling comfortable. I would take a shower, after the shower I would put lotion on my feet, and then put my socks on. When I put those socks on I would sleep like a baby. The Sabbath is a day of rest, you should feel as comfortable as you can get. I make sure that I'm comfortable, I would always sleep with my socks on if I don't, I would have a really hard time falling asleep. On the Sabbath day you should have no hard time resting; I would hate to have a hard time resting on the Sabbath day. When I had hard times resting on the Sabbath; my Sabbath would be ruin. So my socks and my rest plays a very important role on the Sabbath.

\section{African American Male \\ Professor Ifeoma Kwesi \\ Final Exam/Resource File \\ Sabbath keeping}

On Sabbath day the no. one person I spent time keeping the Sabbath with is my girlfriend, Monique Jolicia Celeste Johnson. During the Sabbath we are always together most of the time. We would go to church together and also eat together after church. We keep the Sabbath day holy, we would have our focus on God and God only. After we finish eating we would have a really powerful talk about God. When the Sabbath comes we would stop all our foolish games and be 
mindful in keeping the Sabbath. Our goal is to put God in our relationship and to make God no. one in our lives. So when the Sabbath opens our goals are being put to the test, and most of the time the results are great. My girlfriend is who I keep the Sabbath with, and I thank God for giving her to me. 
African American Female

\section{Sabbath and Sabbath Keeping}

Growing up I always felt that this "Sabbath" was a burden, a time where you can't do anything but entertain yourself by placing God in front of it. This mindset carried over till my teenage years and then I attended the Spiritual Formation Retreat. From the moment we entered that chapel and received Sabbath cards, I knew this was going to be a special experience. I didn't even know Sabbath cards existed, 1 felt like a child curious about this new approach to the Sabbath. It is for this reason I chose the Sabbath card as a resource for it reminds me of the feeling that something different was going to take place. The other resource was a bookmark that talks about the Holy Spirit in one of Ellen White's books, Counsels on Health. I chose this because I also received this on the Sabbath and it also showed me how intimate the Sabbath is supposed to be. This helps my spiritual formation because it keeps me striving for a more intimate, more personal relationship with Christ and therefore become more like Him. 
African American Male

\section{Sabbath Keeping}

The Sabbath for a lot of people sometimes seems to be another work, because we have so much to do. It seems as though we think Sabbath is the only day we can serve God or do godly things. The Sabbath is supposed to be a day of rest but also a day of service. In all things you have to be temperate. Sometimes we think if we don't serve others on the Sabbath, we are not doing our Christian duty. God has given us six days for us to do outreach. I would suggest that we should not try to fit everything in Sabbath time. Sabbath is to be a day of rest and a day that is spent in constant commune with God. 


\section{Sabbath: Invitation}

Sabbath is my favorite day of the week. Since being spiritual formation I see it totally different now. I included one of the cards that was given to us a representation of an invitation into God's rest. I never viewed Sabbath as a celebration to be invited to. It was more so a law that I would attach the word rest to it. After the retreat I have a whole new view I delight in the fact that God invites us into Him (Shabbat) to rest. When Saturday is ending 1 can't wait till the next.

\section{Sabbath: Pillow}

The pillow included is just a symbol of rest for the Sabbath. For the first time in my academic career, I've celebrated Sabbath and didn't stress over what work would be waiting for me when it ended. This Semester was an awesome experience of coming into God's rest. The pillow I made consist of some orange colored scrap fabric, tissue filling, sunflower buttons and thread. Continuing here on earth in His rest is a teaser for what he has in store for us in heaven. 


\section{APPENDIX E}

PHOTOGRAPHS OF CLASS GIFT TO PROFESSOR KWESI: SHABBAT FOUNTAIN

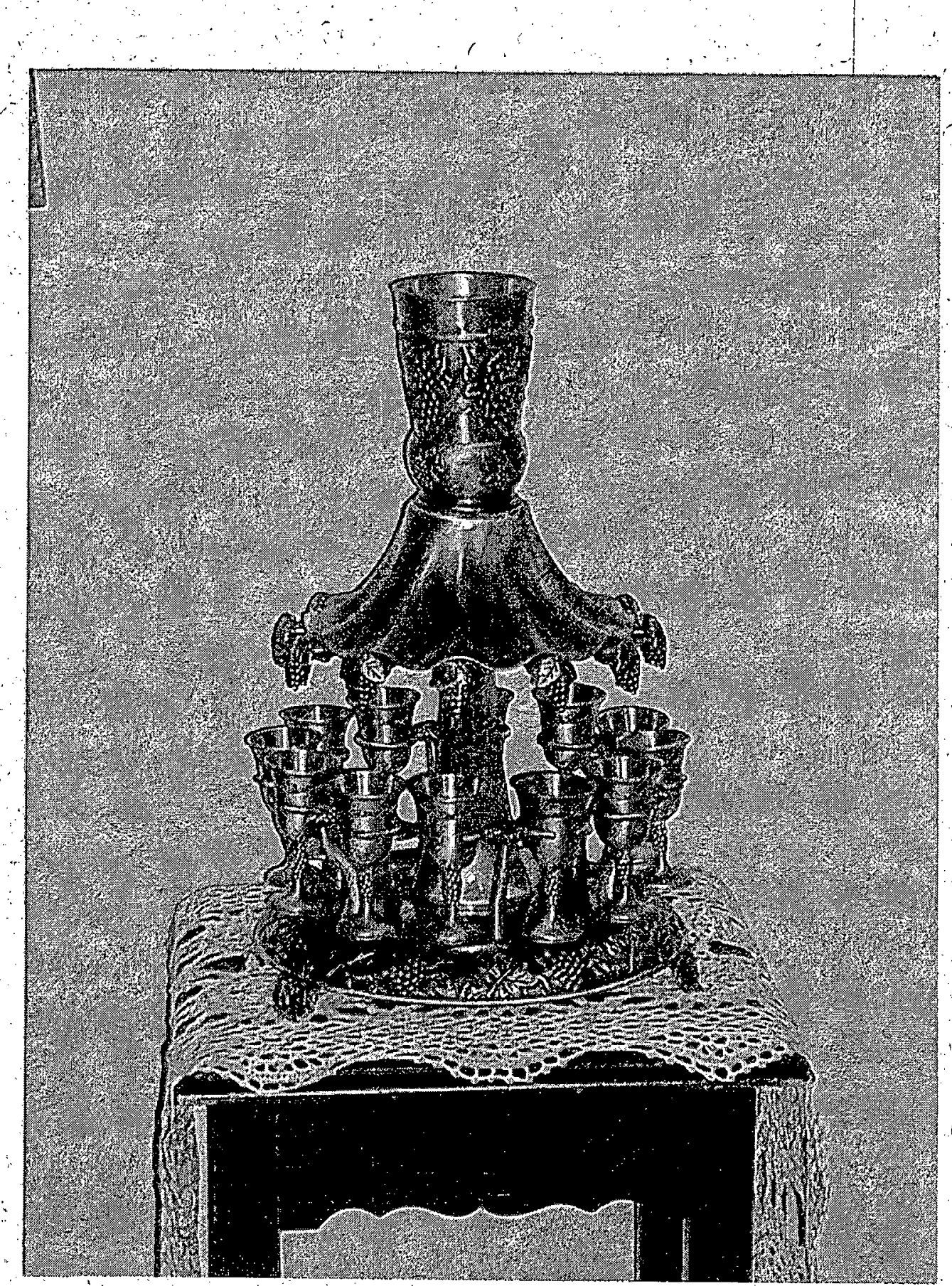




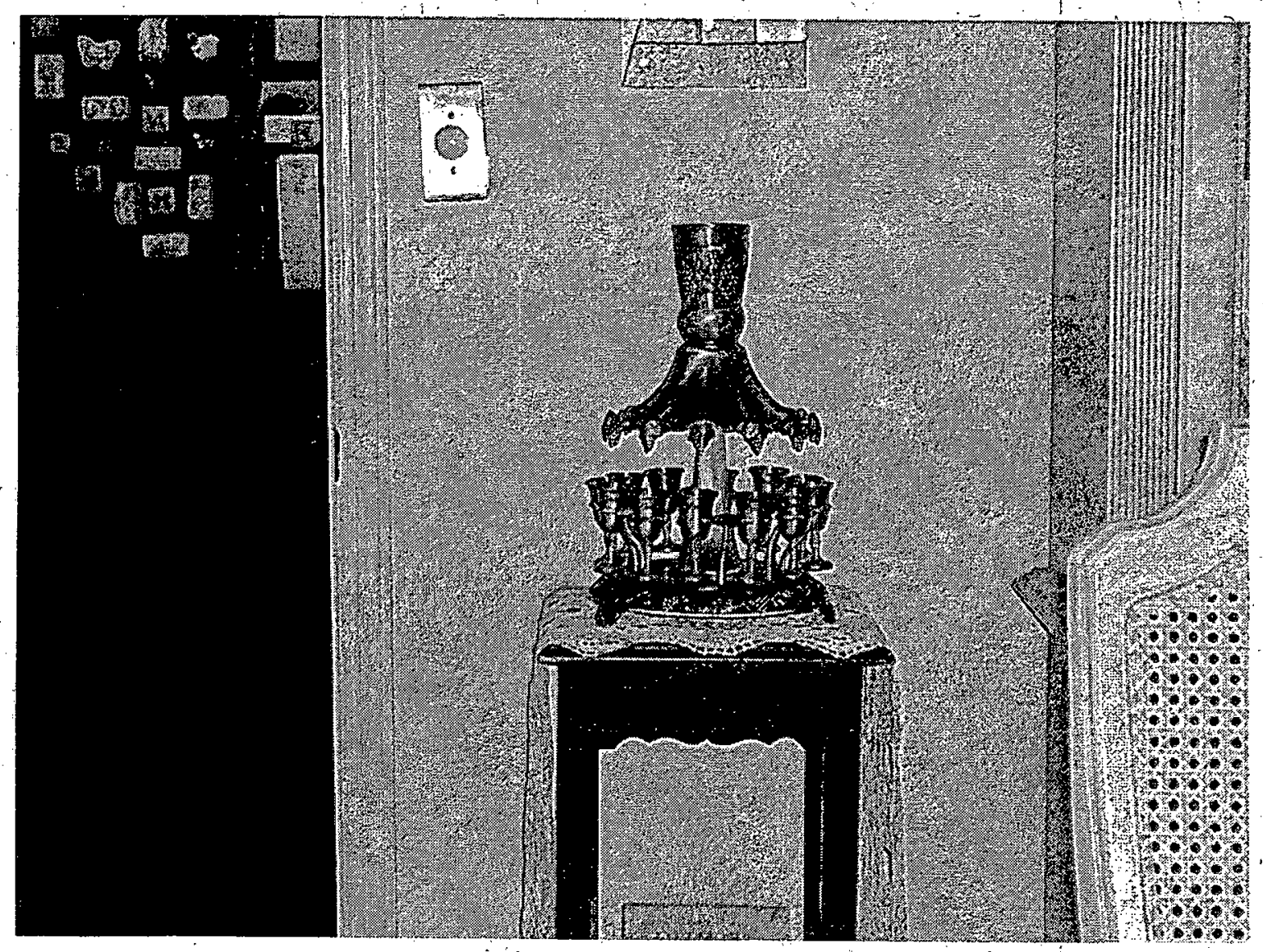




\section{BIBLIOGRAPHY}

"Adventist Beliefs, Mission Statement of the Seventh-day Adventist Church." www.adventist.org/beliefs/statements/main_stat1.html (accessed July 21, 2009).

Allen, Edward Martin. "Rest as a Spiritual Discipline: The Meaning and Manner of Sabbath Observance." DMin dissertation, Fuller Theological Seminary, 1991.

Allen, Gregory J. "How Shall I 'Keep' the Sabbath Holy?" Adventist Review, August 29, 1996, 23-25.

Allen, William Loyd. "Editorial Introduction: Christian Spirituality in the Age of Growing Secularity." Perspectives in Religious Studies 31, no. 1 (Spring 2004): 5-6.

Anderson, Ray S. The Shape of Practical Theology: Empowering Ministry with Theological Praxis. Downers Grove, IL: InterVarsity Press, 2001.

Andreasen, Niels-Erik. "Is God Coming to Campus Too? Thoughts on the Distinctive Features of Adventist Higher Education." Journal of Research on Christian Education 14, no. 2 (Fall 2005): 121-128.

. "The Old Testament and Spiritual Formation." In Project Affirmation: Perspectives on Values, edited by V. Bailey Gillespie, 111-140. Riverside, CA: La Sierra University Press, 1993.

. "The Old Testament Sabbath." Dissertation series, No. 7. Missoula, MT: Society of Biblical Literature, 1972.

. Rest and Redemption. Berrien Springs, MI: Andrews University Press, 1978.

Andrews, Alan, ed. The Kingdom Life: A Practical Theology of Discipleship and Spiritual Formation. Colorado Springs, CO: NavPress, 2010.

Armstrong, Herbert W. Which Day Is the Christian Sabbath? Pasadena, CA: Worldwide Church of God, 1976.

Astley, Jeff, Leslie J. Francis, and Colin Crowder, eds. Theological Perspectives on Christian Formation: A Reader on Theology and Christian Education. Grand Rapids: Wm. B. Eerdmans, 1996. 
Astin, Alexander, Helen Astin, and Jennifer Lindholm. Cultivating the Spirit: How College Can Enhance Students' Inner Lives. San Francisco: Jossey-Bass, 2010.

Augsburger, Daniel. "The Sabbath and the Lord's Day during the Middle Ages." In The Sabbath in Scripture and History, edited by Kenneth A. Strand, 190-214. Washington, DC: Review and Herald, 1982.

Baab, Lynne M. Sabbath Keeping: Finding Freedom in the Rhythm of Rest. Downers Grove, IL: InterVarsity Press, 2005.

Bacchiocchi, Samuele. Divine Rest for Human Restlessness. Berrien Springs, MI: Biblical Perspectives, 1980 . From Sabbath to Sunday. Rome, Italy: Pontifical Gregorian University, 1977. .The Sabbath in the New Testament. Berrien Springs, MI: Biblical Perspectives, 1985. . The Sabbath Under Crossfire: A Biblical Analysis of Recent Sabbath/Sunday Developments. Berrien Springs, MI: Biblical Perspectives, 1998.

Baker, Benjamin, comp. A Place Called Oakwood. Hagerstown, MD: Review and Herald, 2007.

Baker, Delbert, and Susan Baker. "Pathways to Success: Recruitment and Retention Methods at Oakwood College." In How Black Colleges Empower Black Students, edited by Frank W. Hale Jr., 143. Sterling, VA: Stylus Publishing, LLC, 2006.

Ban, Joseph D., ed. The Christological Foundations for Contemporary Theological Education. Macon, GA: Mercer University Press, 1988.

Banks, Robert. Reenvisioning Theological Education: Exploring a Missional Alternativeto Current Modes. Grand Rapids, MI: Wm. B. Eerdmans, 1999. . The Tyranny of Time. Downers Grove, IL: InterVarsity Press, 1983.

Barton, Ruth Haley. Invitation to Solitude and Silence: Experiencing God's Transforming Presence. Downers Grove, IL: InterVarsity Press, 2004.

. Sacred Rhythms: Arranging Our Lives for Spiritual Transformation. Downers Grove, IL: InterVarsity Press, 2006.

Bass, Dorothy C. "Christian Formation in and for Sabbath Rest." Interpretation: A Journal of Bible and Theology 59, no. 1 (2005): 25. 
. Practicing Our Faith: A Way of Life for a Searching People. San Francisco: Jossey-Bass, 1997.

."Rediscovering the Sabbath: The Sabbath Is the Most Challenging-and Necessary-Spiritual Discipline for Contemporary Christians." Christianity Today 47, no. 11 (1997): 38.

Bauckham, R. J. "Sabbath and Sunday in the Medieval Church in the West." In From Sabbath to Lord's Day, edited by D. A. Carson, 299-309. Grand Rapids: Zondervan, 1982.

. "Sabbath and Sunday in the Post-Apostolic Church." In From Sabbath to Lord's Day, edited by D. A. Carson, 251-298. Grand Rapids: Zondervan, 1982.

. "Sabbath and Sunday in the Protestant Tradition." In From Sabbath to Lord's Day, edited by D. A. Caron, 311-341. Grand Rapids: Zondervan, 1982.

Beasley-Topliffe, Keith, ed. The Upper Room Dictionary of Christian Spiritual Formation. Nashville, TN: Upper Room Books, 2003.

Behnken, Kenneth. "Profile of Seekers." Missio apostolica 13, no. 2 (2005): 117-129.

Bellah, Robert N., Richard Madsen, William M. Sullivan, Ann Swidler, and Steven M. Tipton. Habits of the Heart. New York: Harper \& Row, 1985.

Benson, Peter L., Eugene C. Roehlkepartain, and Stacey P. Rude. "Spiritual Development in Childhood and Adolescence: Toward a Field of Inquiry." Applied Developmental Science 7, no. 3 (2003): 205-213.

Benson, Robert. Living Prayer. New York: Jeremy P. Tarcher/Putnam, 1998.

Berger, Fredericka. "Spiritual Formation Through Drama." Arts 15, no. 1 (2003): 34-45.

Berkel, Laverne A., Tonya D. Armstrong, and Kevin O. Cokley. "Similarities and Differences Between Religiosity and Spirituality in African American College Students: A Preliminary Investigation." Counseling and Values 49 (2004): 2-14.

Bloesch, Donald G. Spirituality Old and New: Recovering Authentic Spiritual Life. Downers Grove, IL: InterVarsity Press, 2007.

Boa, Kenneth. Conformed to His Image: Biblical and Practical Approaches to Spiritual Formation. Grand Rapids, MI: Zondervan, 2001.

Bobilya, Andrew J, Lynn Akey, and Donald Mitchell Jr. "Outcomes of a Spiritually Focused Wilderness Orientation Program." Journal of Experiential Education 31, no. 3 (2009): 440-443. 
Bonhoeffer, Dietrich. The Cost of Discipleship. Revised edition. New York: Macmillan, 1963.

Bowman, Nicholas A., and Jenny L. Small. "Do College Students Who Identify with a Privileged Religion Experience Greater Spiritual Development?" Research in Higher Education 51 (2010): 595-614.

Bradford, Charles E. Sabbath Roots: The African Connection. Barre, VT: L. Brown and Sons Printing, 1999.

Branson, Roy, ed. Festival of the Sabbath. Takoma Park, MD: Association of Adventist Forums, 1985.

Braskamp, Larry, Lois Calian Trautvetter, and Kelly Ward. "How College Fosters Faith Development in Students." Spirituality in Higher Education Newsletter 2, no. 3 (2005): 1-6.

. "Putting Students First: Promoting Lives of Purpose and Meaning." About Campus 13, no. 1 (March-April 2008): 26-32.

Browning, Don S. A Fundamental Practical Theology. Minneapolis, MN: Fortress Press, 1991.

Brueggemann, Walter. Finally Comes the Poet: Daring Speech for Proclamation. Minneapolis, MN: Fortress Press, 1989.

Brunt, John. A Day for Healing. Washington, DC: Review and Herald, 1981.

. "The New Testament and Spiritual Values." In Project Affirmation:

Perspectives on Values, edited by V. Bailey Gillespie, 143-174. Riverside, CA:

La Sierra University Press, 1993.

Bryant, Alyssa N., Jeung Yun Choi, and Maiko Yasuno. "Understanding the Religious and Spiritual Dimensions of Students' Lives in the First Year of College." Journal of College Student Development 44, no. 6 (2003): 723-745.

Buchanan, Mark. The Rest of God: Restoring Your Soul by Restoring Sabbath. Nashville, TN: W Publishing Group, 2006.

Buehring, David. A Discipleship Journey: A Navigational Guide to Spiritual Formation and Mentoring. Nashville, TN: Ocean Hill Communications, 2004.

Buker, Bill. "Spiritual Development and the Epistemology of Systems Theory." Journal of Psychology and Theology 31, no. 2 (2003): 143-153. 
Bull, Malcolm, and Keith Lockhart. Seeking a Sanctuary: Seventh-day Adventism \& the American Dream. San Francisco: Harper \& Row Publishers, 1989.

Burridge, Richard. "Jesus and the Origins of Christian Spirituality." In The Story of Christian Spirituality: Two Thousand Years from East to West, edited by Gordon Mursell, 11-30. Minneapolis, MN: Fortress Press, 2001.

Buttrick, George A., ed. "How to Use The Interpreter's Bible." The Interpreter's Bible. Vol. 1. Nashville, TN: Abingdon Press, 1952. xviii.

., ed. Interpreter's Dictionary of the Bible. Nashville, TN: Abingdon Press, 1962. S.v. "Covenant."

Calhoun, Adele Ahlberg. Spiritual Disciplines Handbook: Practices That Transform Us. Downers Grove, IL: InterVarsity Press, 2005.

Callen, Barry L. Authentic Spirituality: Moving Beyond Mere Religion. Grand Rapids, MI: Baker Academic, 2001.

Capeheart-Meningall, Jennifer. "Role of Spirituality and Spiritual Development in Student Life Outside the Classroom." New Directions for Teaching and Learning 104 (2005): 31-36.

Cardozo, Arlene Rossen. Jewish Family Celebration. New York: St. Martin's Press, 1982.

Carlson, Paula J., and Peter S. Hawkins. Listening for God. Minneapolis, MN: Augsburg Press, 1994.

Carson, D. A. "Jesus and the Sabbath in the Four Gospels." In From Sabbath to Lord's Day, edited by D. A. Carson, 57-97. Grand Rapids: Zondervan, 1982.

Cepero, Helen H. "Living with God: A Trinitarian Understanding of Spiritual Formation." In In Spirit and in Truth: Essays of Theology, Spirituality, and Embodiment in Honor of C. John Weborg, edited by Phil J. Anderson and Michelle A. Clifton-Soderstrom, 234. Chicago: Covenant Publications, 2006.

Cetuk, Virginia S. What to Expect in Seminary: Theological Education as Spiritual Formation. Nashville, TN: Abingdon Press, 1998.

Cherry, Conrad, Betty A. DeBerg, and Amanda Porterfield. Religion on Campus: What Religion Really Means to Today's Undergraduates. Chapel Hill, NC: University of North Carolina Press, 2001.

Chickering, Arthur W. Encouraging Authenticity and Spirituality in Higher Education. San Francisco: Jossey-Bass, 2005. 
Chickering, Arthur W., Jon C. Dalton, and Liesa Stamm, Encouraging Authenticity and Spirituality in Higher Education, San Francisco: Jossey-Bass, 2006.

Chittister, Joan. The Ten Commandments: Laws of the Heart. Maryknoll, NY: Orbis Books, 2009.

Clemmons, William. "Spiritual Formation in Seminary Education." Review and Expositor 101 (2004): 41-66.

Cloud, Henry, and John Townsend. How People Grow: What the Bible Reveals About Personal Growth. Grand Rapids, MI: Zondervan, 2001.

Cole, H. Ross. "The Sacred Times Prescribed in the Pentateuch: Old Testament Indicators of the Extent of Their Applicability." $\mathrm{PhD}$ dissertation, Andrews University, 1996.

Collins, Kennth J., ed. Exploring Christian Spirituality: An Ecumenical Reader. Grand Rapids, MI: Baker Books, 2000.

Collinson, Sylvia Wilkey. "Making Disciples and the Christian Faith." Evangelical Review of Theology 29, no. 3 (2005): 240-250.

Colon, May Ellen. From Sundown to Sundown: How to Keep the Sabbath . . and Enjoy it! Nampa, ID: Pacific Press, 2008.

Conn, Joann Wolski. "Spiritual Formation." Theology Today 56, no. 1 (1999): 86.

Cowan, Steven B. Exploring Christian Spirituality. Grand Rapids, MI: Baker Books, 2000.

Creswell, John W. Research Design: Qualitative, Quantitative and Mixed Methods Approaches. Second edition. Thousand Oaks, CA: SAGE Publications, 2003.

Crisp, Beth R. "Beyond the Seminary: New Frontiers for Teaching Spirituality." Religious Education 104, no. 1 (January-February 2009): 4-17.

Cummings, Des, Jr. Original Love: Experience Peace, Meaning and Harmony Through Sabbath Rest. Fallbrook, CA: Hart Books, 2001.

Cuyjet, Michael J. African American Men in College. San Francisco: Jossey-Bass, 2006.

Daily, Steven. Adventism for a New Generation. Portland/Clackamas, OR: Better Living Publishers, 1993. 
Dalton, Jon C., David Eberhardt, Jillian Bracken, and Keith Echols. "Inward Journeys: Forms and Patterns of College Student Spirituality." Journal of College and Character 7, no. 8 (October 2006): 1-22.

Dash, Michael I. N., and Stephen C. Rasor. "African American Spirituality: Some Biblical and Historical Resources for Reflection." Ex auditu 18 (2002): 120-136.

Davidson, Richard M. A Love Song for the Sabbath: How to Experience the Joy That God Intended When He Gave Us the Sabbath. Washington, DC: Review and Herald, 1988.

. "The Sabbath in the Old Testament Psalms and Wisdom Literature." Paper presented to the Biblical Research Institute Committee, Andrews University, Berrien Springs, MI, October 22, 2007.

. "Sabbath, Spirituality and Mission: Torah's Seven Dimensions of Sabbath Rest." In Encountering God in Life and Mission, ed. Rudi Maier. Berrien Springs, MI: Department of World Mission, 2010.

Dawn, Marva. Keeping the Sabbath Wholly: Ceasing, Resting, Embracing, Feasting. Grand Rapids, MI: Wm. B. Eerdmans, 1989.

.The Sense of the Call: A Sabbath Way of Life for Those Who Serve God, the Church, and the World. Grand Rapids, MI: Wm. B. Eerdmans, 2006.

de Benedicto, Marcos. "A Search for Spirituality." Ministry: International Journal for Pastors, February 2006, 12.

De Jong, Arthur J. Reclaiming a Mission: New Direction for the Church-Related College. Grand Rapids, MI: Wm. B. Eerdmans, 1990.

DeLacey, D. R. "The Sabbath/Sunday Question and the Law in the Pauline Corpus." In From Sabbath to Lord's Day, edited by D. A. Carson, 159-195. Grand Rapids, MI: Zondervan, 1982.

Demarest, Bruce. Satisfy Your Soul: Restoring the Heart of Christian Spirituality. Colorado Springs, CO: NavPress, 1999. Quoted in Evan Howard, "Three Temptations of Spiritual Formation," Christianity Today 46, no. 13 (2002): 48.

Dennis, Dixie L., Terence Hicks, Priya Banerjee, and Brent Dennis. "Spirituality Among Predominantly African American College Student Population." American Journal of Health Studies 20, nos. 3/4 (2005): 135-142.

The Division of Student Services of Oakwood College. "Oakwood College Student's Bill of Rights." Student Handbook 2007-2009. Huntsville, AL: Oakwood College, 2009. 
Donahoo, Saran, and Ronald A. Caffey. "A Sense of Home: The Impact of Church Participation on African American College Students." Journal of Research on Christian Education 19 (2010): 79-104.

Donato, Christopher J. "Introduction." In Perspectives on the Sabbath, edited by Christopher J. Donato, 1-8. Nashville, TN: B \& H Academic, 2011.

Dressler, Harold H. P. "The Sabbath in the Old Testament." In From Sabbath to Lord's Day, edited by D. A. Carson, 21-41. Grand Rapids, MI: Zondervan, 1982.

Driskill, Joseph D. Protestant Spiritual Practices: Theology, History and Practice. Harrisburg, PA: Morehouse Publishing, 1999.

Dudley, Roger L. The Complex Religion of Teens: A Lifetime of Research Reveals How Adolescents Relate to Spiritual Matters. Hagerstown, MD: Review and Herald, 2007.

.Why Our Teenagers Leave the Church: Personal Stories from a 10-Year Study. Hagerstown, MD: Review and Herald, 2000.

.Why Teenagers Reject Religion and What to Do About It. Washington, DC: Review and Herald, 1978.

Dudley, Roger, and Steve Case. "Developing Spiritual Values." In Project Affirmation: Perspectives on Values, edited by V. Bailey Gillespie, 47-77. Riverside, CA: La Sierra University Press, 1993.

Dudley, Roger, and Robert Cruise. "Measuring Religious Maturity: A Proposed Scale." Review of Religious Research 32, no. 2 (December 1990): 97-109.

Dulan, C. Garland. "Is Adventist Education Worth It?" The Journal of Adventist Education 66, no. 3 (2004): 3.

Dunham, Maxie. The Workbook on Spiritual Disciplines. Nashville, TN: Upper Room Books, 1984.

Dybdahl, Jon. Hunger: Satisfying the Longing of Your Soul. Hagerstown, MD: Review and Herald, 2008.

. "A Wayward Wife and a Hurting Husband." Hosea-Micah: A Call to Radical Reform. The Abundant Life Bible Amplifier. General editor, George R. Knight. Boise, ID; Pacific Press, 1996.

Edgell, Margaret S. "Afrocentric Christian Worldview and Student Spiritual Development: Tapping a Global Stream of Knowledge." Journal of Education and Christian Belief 11, no. 1 (2007): 49-62. 
Education as Transformation. www.wellesley.edu/RelLife/transformation/index.html (accessed January 10, 2011).

Edwards, Tilden. "The Christian Sabbath: Its Promise Today as a Basic Spiritual Discipline." Worship 56, no. 1 (1982): 2. . Sabbath Time. Revised edition. Nashville, TN: Upper Room Books, 2003.

Erricker, Clive. "Shall We Dance? Authority, Representation and Voice: The Place of Spirituality in Religious Education." Religious Education 96, no. 1 (2001): 20-35.

Estep, James R., and Jonathan H. Kim, eds. Christian Formation: Integrating Theology and Human Development. Nashville, TN: B\&H Academic, 2010.

Ford, Robert Leroy. A Curriculum Design Manual for Theological Education: A Learning Outcomes Focus. Eugene, OR: Wipf and Stock Publishers, 1991.

Fortin, Denis et al. A Statement on Biblical Spirituality. www.andrews.edu/sem/sdats _bibspir.pdf (accessed May 15, 2012).

Fortin, Denis. Teaching Biblical Spirituality. www.andrews.edu/sem/response/html (accessed May 15, 2012).

Fortosis, Stephen. "Theological Foundations for a Stage Model of Spiritual Formation." Religious Educatión 96, no. 1 (2001): 49.

Foster, Charles R. "Teaching and Learning in the Service of Transformation." Change 39 , no. 3 (2007): 38-42.

Foster, Richard. Celebration of Discipline: The Path to Spiritual Growth. Revised edition. San Francisco: Harper \& Row, 1998.

.The Renovare Spiritual Formation Bible. San Franscisco:

HarperSanFrancisco, 2005.

. "Spiritual Formation Agenda." Christianity Today 53, no. 1 (2009): 28.

Fowler, James W. "Faith Development at 30: Naming the Challenges of Faith in a New Millennium." Religious Education 99, no. 4 (Fall 2004): 405-421.

. "Faith Development Theory and the Postmodern Challenges." The

International Journal for the Psychology of Religion 11, no. 3 (2001): 159-172.

. Stages of Faith: The Psychology of Human Development and the Quest for Meaning. New York: Harper \& Row, 1981. 
Franklin, Robert M. Another Day's Journey: Black Churches Confronting the American Crisis. Minneapolis, MN: Fortress Press, 1997.

Frey, Mathilde. "The Sabbath Commandment in the Book of the Covenant: Ethics on Behalf of the Outcast." Journal of Asia Adventist Seminary 9, no. 1 (2006): 3-11.

. The Sabbath in the Pentateuch: An Exegetical and Theological Study. $\mathrm{PhD}$ dissertation, Andrews University, 2011.

Frye, Steven Blake. How Adult Students Experience Having Their Beliefs Challenged in (an Undergraduate Religion Class: A Phenomenological Analysis. Unpublished doctoral dissertation, University of Tennessee, Knoxville, 2007.

Frye, Steven. "Religious Education and Faith Challenges in the College Classroom." Adult Learning 18, nos. 1/2 (2007): 12-14.

Fuller, Paula. "Participating in God's Mission." The Kingdom Life: A Practical Theology of Discipleship and Spiritual Formation. Colorado Springs, CO: NavPress, 2010.

Galindo, Israel. "Methods of Christian Education toward Christian Spiritual Formation." Review and Expositor 98 (2001): 411-429.

Gall, Meredith D., Joyce P. Gall, and Walter R. Borg. Educational Research: An Introduction. Eighth edition. Boston, MA: Allyn \& Bacon, 2006.

Gallien, Louis, and LaTrelle Jackson. "Character Development from African-American Perspectives: Toward a Counternarrative Approach." Journal of Education and Christian Belief 10, no. 2 (2006): 129-142.

Gallos, Erhard H. "KATAחAY $\Sigma I \Sigma$ and $\Sigma A B B A T I \Sigma M O \Sigma$ in Hebrews 4." PhD. dissertation, Andrews University, 2011.

Gallup, George, Jr., and Timothy Jones. The Next American Spirituality: Finding God in the Twenty-First Century. Colorado Springs, CO: Cook Communications, 2000.

Gane, Roy. The NIV Application Commentary: Leviticus, Numbers. Grand Rapids, MI: Zondervan, 2004.

. The Role of God's Moral Law, Including Sabbath, in the 'New Covenant.' Berrien Springs, MI: Andrews University Press, 2003.

Gangel, Kenneth O., and James C. Wilhoit. The Christian Educator's Handbook on Spiritual Formation. Grand Rapids: Baker Books, 1994.

Garber, Steven. The Fabric of Faithfulness: Weaving Together Belief and Behavior during the University Years. Downers Grove, IL: InterVarsity Press, 1996. 
Gebhard, Duane M. The Growing Points Star: A Tool for Disciple Formation. Nashville, TN: Discipleship Resources, 2000.

Gemignani, Michael. Spiritual Formation for Pastors: Feeding the Fire Within. Valley Forge, PA: Judson Press, 2002.

Giamatti, A. Barlett. Take Time for Paradise: Americans and Their Games. Summit Books, 1989. Excerpts in Newsweek, 6 November 1989, 87-88.

Gillespie, V. Bailey. "Catching God's Grace: Youth Ministry Spirituality." In Getting it Right: A Powerful Package-Resource for Adventist Youth Leaders. Hagerstown, MD: Review and Herald, 2005.

. Project Affirmation: Perspectives on Values. Riverside, CA: La Sierra

University Press, 1993.

Spirituality: Some Questions. Riverside, CA: Hancock Center for Youth and Family Ministry, La Sierra University Press, 2000.

.Valuegenesis Ten Years Later: A Study of Two Generations. Riverside, CA: Hancock Center Publications, 2004.

Gilligan, Carol. In a Different Voice: Psychological Theory and Women's Development. Cambridge, MA: Harvard University Press, 1982.

Goldstein, Clifford. A Pause for Peace: What God's Gift of the Sabbath Can Mean to You. Boise, ID: Pacific Press, 1992.

Groeschel, Benedict J. Spiritual Passages: The Psychology of Spiritual Development. New York: Crossroads, 1986.

Guthrie, Stan. "Relentless Pursuit: Mark Buchanan Examines the Fruit of Spiritual Disciplines." Christianity Today 51, no. 4 (April 2007): 86-87.

Guy, Fritz. Thinking Theologically: Adventist Christianity and the Interpretation of Faith. Berrien Springs, MI: Andrews University Press, 1999.

Hagberg, Janet O., and Robert Guelich. The Critical Journey: Stages in the Life of Faith Salem, WI: Sheffield Publishing Company, 2005.

Hale, Frank W., Jr. Angels Watching Over Me: The Autobiography of Dr. Frank W. Hale, $J r$. Nashville: James C. Winston Publishers Group, 1996.

. How Black Colleges Empower Black Students: Lessons for Higher Education. Sterling, VA: Stylus, 2006. 
Hall, Kenley D. "Guidelines for Doctor of Ministry Projects." Berrien Springs, MI: Andrews University Seventh-day Adventist Theological Seminary, 2009.

Hasel, Gerhard. "The Sabbath in the Pentateuch." In The Sabbath in Scripture and History, edited by Kenneth A. Strand, 21-43. Washington, DC: Review and Herald, 1982.

Hasel, Gerhard, and W. G. C. Murdoch, "The Sabbath in the Prophetic and Historical Literature of the Old Testament." In The Sabbath in Scripture and History, edited by Kenneth A. Strand, 44-56. Washington, DC: Review and Herald, 1982.

HBCU. http://www.uncf.org/aboutus/hbcus.asp (accessed July 5, 2009).

HERI Spirituality Project Team. "Spirituality \& the Higher Education Curriculum: The HERI Syllabi Project." Spirituality in Higher Education Newsletter 2, no. 2 (April 2005): $1-4$.

Herndon, Michael K. "Expressions of Spirituality Among African American College Males." Journal of Men's Studies 12, no. 1 (2003): 75-84.

Heschel, Abraham Joshua. The Sabbath: Its Meaning for Man. Expanded edition. New York: Harper \& Row Publishers, 1952.

Heye, Bekele. The Sabbath in Ethiopia: An Exploration of Christian Roots. Lincoln, NE: Center for Creative Ministry, 2003.

Hinchey, Patricia H. Action Research Primer. New York: Peter Lang Publishing, 2008.

Hindman, David. "From Splintered Lives to Whole Persons: Facilitating Spiritual Development in College Students." Religious Education 97, no. 2 (Spring 2002): 165-182.

Hinson, E. Glenn. Spiritual Preparation for Christian Leadership. Nashville, TN: Upper Room Books, 1999.

Holly, Mary Louise, Joanne M. Arhar, and Wendy C. Kasten. Action Research for Teachers: Traveling the Yellow Brick Road. Third edition. Boston, MA: Allyn \& Bacon, 2009.

Holmes, Arthur F. The Idea of a Christian College. Grand Rapids, MI: Wm. B. Eerdmans, 1987.

Shaping Character: Moral Education in the Christian College. Grand Rapids, MI: Wm. B. Eerdmans, 1991. 
Holmes, Barbara A. Joy Unspeakable: Contemplative Practices of the Black Church. Minneapolis, MN: Fortress Press, 2004.

Honeycutt, Frank G. "Growing Christians: A Four-Stage Catechism." Christian Century, February 22, 2011, 35-41.

Horell, Harold D. "Fostering Hope: Christian Religious Education in a Postmodern Era." Religious Education 99, no. 1 (2004): 5-22.

Howard, Evan. The Brazos Introduction to Christian Spirituality. Grand Rapids, MI: Brazos Press, 2008.

. "Three Temptations of Spiritual Formation." Christianity Today 46, no. 13 (2002): 46.

"Interpretation of Genesis." Seventh-day Adventist Bible Commentary. Edited by F. D. Nichol. Washington, DC: Review and Herald Publishing Association, 1980. 1:220-221.

"Interpretation of Hebrews," Seventh-day Adventist Bible Commentary. Edited by F. D. Nichol. Washington, DC: Review and Herald Publishing Association, 1980. $7: 413$.

Jarvis, Peter. "Religious Experience and Experiential Learning." Religious Education 103, no. 5 (2007): 553-567.

Jenni, Ernst, and Claus Westerman. Theological Lexicon of the Old Testament. Vol. 1. Translated by Mark E. Biddle. Peabody, MA: Hendrickson Publishers, 1997. 255.

Johnsen, Carsten. Day of Destiny: The Mystery of the Seventh Day. Loma Linda, CA: The Untold Story Publishers, 1982.

Johnson, Mark Randall. "Sabbath Living: Recovering the Sabbath for Renewal and Ministry." D.Min. dissertation, Pacific Lutheran Theological Seminary, 1986.

Johnson, Susanne. "Christian Spiritual Formation in an Age of 'Whatever." Review \& Expositor 98, no. 3 (2001): 309-331.

Johnsson, William G. Hebrews: Full Assurance for Christians Today. The Abundant Life Bible Amplifier. General editor George R. Knight. Boise, ID: Pacific Press, 1994.

Johnston, Robert M. "The Rabbinic Sabbath." In The Sabbath in Scripture and History, edited by Kenneth A. Strand, 70-91. Washington, DC: Review and Herald, 1982. . The Spiritual Life: Experiencing Jesus Christ as Lord. Nampa, ID: Pacific Press, 2005. 
Jones, L. Gregory, and Willie James Jennings. "Formed for Ministry: A Program in Spiritual Formation." Christian Century 117, no. 4 (2000): 124.

Jones, Tony. The Sacred Way: Spiritual Practices for Everyday Life. Grand Rapids, MI: Zondervan, 2005.

Kaiser, Walter C., Jr. Toward Old Testament Ethics. Grand Rapids, MI: Zondervan, 1983.

Kavanaugh, Patrick. Worship-A Way of Life. Grand Rapids, MI: Baker Books, 2001.

Kelcourse, Felicity B., ed. Human Development and Faith: Life-Cycle Stages of Body, Mind, and Soul. St. Louis, MO: Chalice Press, 2004.

Kiddush ceremony. www.myjewishlearning.com/practices (accessed May 2009).

Kiddush fountain. www.traditionsjewishgifts.com (accessed May 2009).

Kiesling, Chris A., Gwendolyn T. Sorrell, Marilyn J. Montgomery, and Ronald K. Colwell. "Identity Research and the Psychosocial Formation of One's Sense of Spiritual Self: Implications for Religious Educators and Christian Institutions of Higher Education." 3rd series. Christian Education Journal 3, no. 2 (Fall 2006): 240-259.

Killen, Melanie, and Judith Smetana, eds. Handbook of Moral Development. Mahwah, NJ: Lawrence Erlbaum Associates, 2006.

Kimball, Dan. The Emerging Church: Vintage Christianity for New Generations. Grand Rapids, MI: Zondervan, 2003.

Kinnaman, David, and Gabe Lyons. Unchristian: What a New Generation Thinks About Christianity. Grand Rapids, MI: Baker Books, 2007.

Kitwana, Bakari. he Hip Hop Generation: Young Blacks and the Crisis in AfricanAmerican Culture. New York: Basic Civitas Books, 2002.

Klink, Mary. "Creating Shared Vision for Promoting Students' Spiritual Development: An Intervention Model from Edgewood College." Spirituality in Higher Education Newsletter 5, no. 3 (2003): 1-10.

Knight, George R. The Apocalyptic Vision and the Neutering of Adventism. Hagerstown, MD: Review and Herald, 2008. . A Brief History of Seventh-day Adventists. Hagerstown, MD: Review and Herald, 1999. 
. Philosophy and Education: An Introduction in Christian Perspective. Berrien Springs, MI: Andrews University Press, 1998.

. A Search for Identity: The Development of Seventh-day Adventist Beliefs.

Hagerstown, MD: Review and Herald, 2000.

Kohlberg, Lawrence. The Philosophy of Moral Development. San Francisco: Harper \& Row, 1981.

Kolb, David A. Experiential Learning: Experience as the Source of Learning and Development. Upper Saddle River, NJ: Prentice Hall, 1983.

Koth, Kent. "Deepening the Commitment to Serve: Spiritual Reflection in Service Learning." About Campus 7, no. 6 (2003): 2-7.

Kubo, Sakae. God Meets Man: A Theology of the Sabbath and Second Advent. Nashville, TN: Southern Publishing Association, 1978.

Kuh, George D., and Robert M. Gonyea. "Spirituality, Liberal Learning and College Student Engagement." Liberal Education 92, no. 1 (Winter 2006): 40-47.

Kuhalampi, Harri. Holistic Spirituality in the Thinking of Ellen White. Doctoral Dissertation, University of Helsinki, 2010.

Kuhlman, Delcy, and Tom Kuhlman. "Still Waters." www.ComeBeStill.org (accessed June 16, 2009).

Lapsley, Daniel K. "Moral Stage Theory." In Handbook of Moral Development, edited by Melanie Killen and Judith Smetana, 45-52. Mahwah, NJ: Lawrence Erlbaum Associates, 2006.

Laurence', Peter. "Education as Transformation: History of a Movement." Spirituality in Higher Education Newsletter 1, no. 1 (April 2004): 1-4.

."Teaching, Learning, \& Spirituality." Spirituality in Higher Education Newsletter 2, no. 2 (April 2005): 1-6.

Lawrenz, Mel. The Dynamics of Spiritual Formation. Grand Rapids, MI: Baker Books, 2000.

Laytham, Brent. "Let Us Pray: Classroom Worship in Theological Education." Teaching Theology and Religion 13, no. 2 (April 2010): 110-124.

Leicester, Mal. Spiritual and Religious Education. New York: Falmer Press, 2000. 
Leith, John H. Crisis in the Church: The Plight of Theological Education. Louisville, KY: Westminster John Knox Press, 1997.

Leonard, Bill. Becoming Christian: Dimensions of Spiritual Formation. Louisville, KY: Westminster John Knox Press, 1990.

Liebelt, Gerita Garver. From Dilemma to Delight. Washington, DC: Review and Herald, 1986.

Lincoln, A. T. "Sabbath, Rest, and Eschatology in the New Testament." In From Sabbath to Lord's Day, edited by D. A. Carson, 197-220. Grand Rapids: Zondervan, 1982.

Lindholm, Jennifer A. "Spirituality in the Academy: Reintegrating Our Lives and the Lives of Our Students." About Campus, September-October 2007, 10.

Londis, James J. God's Finger Wrote Freedom. Washington, DC: Review, and Herald, 1978.

Longwood, W. Merle, Mark W. Muesse, and William Schipper. "Men, Spirituality, and the Collegiate Experience." New Directions for Student Services 107 (Fall 2004): 87-95.

Lyons, Gabe. The Next Christians: The Good News About the End of Christian America and How a New Generation Is Restoring the Faith. New York: Doubleday, 2010.

Ma, Stella. "The Christian College Experience and the Development of Spirituality Among Students." Christian Higher Education 2 (2003): 321-339.

MacCarty, Skip. In Granite or INGRAINED? What the Old and New Covenants Reveal About the Gospel, the Law, and the Sabbath. Berrien Springs, MI: Andrews University Press, 2007.

.The Seventh-day Sabbath." In Perspectives on the Sabbath, edited by Christopher Donato, 9-72, 99-118. Nashville, TN: B \& H Publishing Group, 2011.

Maddix, Mark A. "Spiritual Formation and Christian Formation." In Christian Formation: Integrating Theology and Human Development, edited by James Estep and Jonathan Kim, 237-271. Nashville, TN: B \& H Publishing Group, 2010.

Maddix, Mark A., and James R. Estep, Jr. "Spiritual Formation in Online Higher Education Communities: Nurturing Spirituality in Christian Higher Education Online Degree Programs." 3rd series. Christian Education Journal 7, no. 2 (Fall 2010): 423-434. 
Malveaux, Julianne. "Vanishing Black College Students?" Black Issues in Higher Education 21, no. 24 (2005): 35.

Mannoia, V. James. Christian Liberal Arts: An Education That Goes Beyond. Lanham, MD: Rowman \& Littlefield Publishers, 2000.

Marcum, Walt. Deepening Youth Spirituality: The Youth Worker's Guide. Nashville, TN: Abingdon Press, 2001.

Martin, Thomas W. "Faith in the Classroom: The Perspective of a Pastor Called to College Teaching." Teaching Theology and Religion 11, no. 4 (2008): 213-221.

Maxson, Ben. "Living Holiness: Learning to Accept the Gift." Adventist Review, May 2006.

McDonald, Patrick J. "Bedrock Elements of Spiritual Growth." Human Development 17, no.1 (1996): 36.

McElvaney, William K. Winds of Grace, Ways of Faith: Expanding the Horizons of Christian Spirituality. Louisville, KY: Westminster John Knox Press, 1991.

McIver, Robert K. "The Services of the New Temple." In Ezekiel: Through Crisis to Victory. The Abundant Life Bible Amplifier. General editor George R. Knight. Boise, ID: Pacific Press, 1997.

McKinney, Larry J. "A Theology of Theological Education: Pedagogical Implications." Evangelical Review of Theology 29, no. 3 (2005): 218-227.

McKnight, Scot. "Spirituality in a Postmodern Age." Stone-Campbell Journal 13 (Fall, 2010): 211-224.

McMinn, Mark R., and Todd W. Hall, "Christian Spirituality in a Postmodern Era," Journal of Psychology and Theology 28, no. 4 (2009): 252.

McNeal, Reggie. A Work of Heart: Understanding How God Shapes Spiritual Leaders. San Francisco: Jossey-Bass, 2000.

Meehan, Christopher. "Promoting Spiritual Development in the Curriculum." Pastoral Care in Education 20, no. 1 (2002): 16.

Mikoski, Gordon S. "Speaking of Religious Practices." Theology Today 66 (2009): 271278.

Miller, Calvin. The Table of Inwardness: Nurturing Our Inner Life in Christ. Downers Grove, IL: InterVarsity Press, 1984. 
Miller, John P. Education and the Soul: Toward a Spiritual Curriculum. Albany, NY: State University Press of New York, 2000.

Ministerial Association. Seventh-day Adventists Believe: An Exposition of the Fundamental Beliefs of the Seventh-day Adventist Church. Boise, ID: Pacific Press, 2005.

Modica, Joseph B. “Jesus' Guide to Spiritual Formation." Christianity Today 49, no. 4 (2005): 105.

Morris, Robert Corin. Wrestling With Grace: A Spirituality for the Rough Edges of Daily Life. Nashville, TN: Upper Room Books, 2003.

Mulholland, M. Robert, Jr. The Deeper Journey: The Spirituality of Discovering Your True Self. Downers Grove, IL: InterVarsity Press, 2006.

. Invitation to a Journey: A Road Map for Spiritual Formation. Downers

Grove, IL: InterVarsity Press, 1993.

. Shaped by the Word: The Power of Scripture in Spiritual Formation.

Nashville, TN: Upper Room Books, 2000.

Muller, Wayne. Sabbath: Finding Rest, Renewal, and Delight in Our Busy Lives. New York: Bantam Books, 1999.

Nash, Robert, and Michele C. Murray. Helping College Students Find Purpose: The Campus Guide to Meaning-Making. San Francisco: Jossey-Bass, 2010.

Nelson, Gregory P. A Touch of Heaven: Finding New Meaning in Sabbath Rest. Nampa, ID: Pacific Press, 1999.

New Way of Being Church, "The Pastoral Cycle." http://www.newway.org.uk/ datasheets/pastoral_cycle.php (accessed September 7, 2009).

Nouwen, Henri. Making All Things New: An Invitation to the Spiritual Life. New York: Walker and Company, 1981.

. Spiritual Direction: Wisdom for the Long Walk of Faith. San Francisco: Jossey-Bass, 2006. Quoted in "Spiritual Formation in Seminary Education," Review and Herald, 101 (2004): 63.

Oakwood University Center for Academic Success. New Student Orientation Manual: 2008-2009. Huntsville, AL: Oakwood University, 2008.

Oakwood University Department of Religion and Theology. Student Handbook, 20082009. Huntsville, AL: Oakwood University, 2008. 
Oakwood University Office of Academic Affairs. Oakwood University Bulletin: 20072009. Huntsville, AL: Oakwood University, 2007.

Oakwood University Office of Institutional Effectiveness. Factbook: 2008-2009. Huntsville, AL: Oakwood University, 2009.

. Statistical Data: Enrollment Statistics 2008-2009. Huntsville, AL: Oakwood University, 2009.

Oakwood University Office of Public Relations. Oakwood University Magazine. Spring 2011.

Oakwood University Office of Student Services. Residential Life Guide. Huntsville, AL: Oakwood University, 2009.

. Student Handbook. Huntsville, AL: Oakwood University, 2009.

O'Connell, Timothy E. Making Disciples: A Handbook of Christian Moral Formation. New York: Crossroad Publishers, 1998.

O'Gorman, Robert T. "Effect of Theological Orientation on Christian Education in Spiritual Formation: Toward a Postmodern Model of Spirituality." Review and Expositor 98 (Summer 2001): 351-368.

Ortlund, Anne. Disciplines of the Heart: Tuning Your Inner Life to God. Dallas, TX: Word Publishing, 1987.

Osborne, Grant R. The Hermeneutical Spiral: A Comprehensive Introduction to Biblical Interpretation. Downers Grove, IL: InterVarsity Press, 1991.

Osmer, Richard R. Practical Theology: An Introduction. Grand Rapids, MI: Wm. B. Eerdmans, 2008.

Palmer, Parker J. The Heart of Higher Education: A Call to Renewal. San Francisco: Jossey-Bass, 2010.

. A Hidden Wholeness: The Journey Toward an Undivided Life. San Francisco: Jossey-Bass, 2004.

. To Know and Be Known: Education as a Spiritual Journey. San Francisco: HarperOne, 1993.

Parks, Sharon D. Big Questions; Worthy Dreams: Mentoring Young Adults in Their Search for Meaning, Purpose and Faith. San Francisco: Jossey-Bass, 2011. 
. The Critical Years: Young Adults and the Search for Meaning, Faith and Commitment. New York: HarperCollins, 1991.

Patton, Lori D., and Michelle L. McClure. "Strength in the Spirit: A Qualitative Examination of African American College Women and the Role of Spirituality During College." Journal of Negro Education 78, no. 1 (2009): 42-54.

Paulien, Jon. "Revisiting the Sabbath in the Book of Revelation." Journal of the Adventist Theological Society 9, nos. 1-2 (1998): 179-186.

Peck, M. Scott. The Different Drum. New York: Simon and Schuster, 1987.

Perry, William G. Forms of Intellectual and Ethical Development in the College Years. New York: Holt, Rhinehart, \& Winston, 1970.

Pipa, Joseph A. "The Christian Sabbath." In Perspectives on the Sabbath: Four Views, edited by Christopher John Donato, 164-165. Nashville, TN: B\&H Academic, 2011.

Plantinga, Cornelius. Engaging God's World: A Christian Vision of Faith Learning and Living. Grand Rapids, MI: Wm. B. Eerdmans, 2002.

Plaut, W. Gunter, ed. Shabbat Manual. New York: Ktav Publishing House (Central Conference of American Rabbis), 1972.

Poling, James N., and Donald E. Miller. Foundations for a Practical Theology of Ministry. Nashville, TN: Abingdon Press, 1985.

Pollard, Leslie N. "Vision 20/20." Oakwood University Magazine, Spring 2011, 31.

Postema, Don. Catch Your Breath: God's Invitation to Sabbath Rest. Grand Rapids, MI: CRC Publications, 1997.

. Space for God: The Study and Practice of Prayer and Spirituality. Grand Rapids, MI: CRC Publications, 1983.

Prevost, Ronnie. "Historical Roles of Christian Education in Spiritual Formation." Review and Expositor 98 (2001): 333-349.

"Race and ethnicity in the United States Census." Wikipedia. http://en.wikipedia.org/ wiki/African-American_(U.S .Census) (accessed June 16, 2009).

Rad, Gerhard von. Genesis: A Commentary: A Commentary. Translated by John $\mathrm{H}$. Marks. Philadelphia, PA: The Westminster Press, 1961. 
. Old Testament Theology. Vol. 1. Translated by D. M. G. Stalker. New York: Harper \& Brothers, 1962.

. "There Remains Still a Rest for the People of God." In The Problem of the Hexateuch, translated by E. W. Trueman Dickens. Edinburgh: Oliver \& Boyd, 1966.

Radecke, Mark W. "Service-Learning and the Spiritual Formation of College Students." Word \& World 26, no. 3 (Summer 2006): 289-298.

Rasi, Humberto M. "Adventist Education and the Challenge of Postmodernism." The Journal of Adventist Education (December 2008/January 2009): 11-17.

. "Toward a Statement of Educational Philosophy." Special Edition. Journal of Research on Christian Education 10 (2001): 173-174.

Rasi, Humberto, Paul Brantley, George Akers, John M. Fowler, George Knight, John Matthews, and Jane Thayer. "A Statement of Seventh-day Adventist Educational Philosophy: Version 7.8." Special edition, Journal of Research on Christian Education 10 (2001): 347-355.

Reason, Peter, and Hilary Bradbury, eds. The Handbook of Action Research: The Concise Paperback Edition. Los Angeles, CA: Sage Publications, 2006.

Reisz, H. Frederick, Jr. "Assessing Spiritual Formation in Christian Seminary Communities." Theological Education 39, no. 2 (2003): 29-40.

Riggins, Reginald K., CoSandra McNeal, and Michael K. Herndon. "The Role of Spirituality Among African-American College Males Attending a Historically Black University." College Student Journal 42, no. 1 (2008): 70-81.

Roberts, J. J. M. “Seminaries, 'Spirituality,' and 'Spiritual Formation': A Quick Fix for the Disciplined Life of Faith?" Christian Studies 20 (Fall 2004): 43-50.

Robinson, Gnana. The Origin and Development of the Old Testament Sabbath. Frankfurt am Main, Germany: Verlag Peter Lang, 1988.

Rodriguez, Angel M. The Biblical Sabbath: The Adventist Perspective. Biblical Research Institute. http://www.adventistbiblicalresearch.org/documents/sabbath-catholi (accessed May 26, 2010).

Rowland, C. "Sabbath Observance in Judaism in the Beginning of the Christian Era." In From Sabbath to Lord's Day, edited by D. A. Carson, 43-55. Grand Rapids: Zondervan, 1982. 
Samaan, Philip G. Christ's Way to Spiritual Growth. Hagerstown, MD: Review and Herald, 1995.

Sandage, Steven J., Peter J. Jankowski, and Deborah Link. "Quest and Spiritual Development Moderated by Spiritual Transformation." Journal of Psychology and Theology, 38, no. 1 (2010): 15-31.

Sanders, Cheryl J. "African Americans, the Bible \& Spiritual Formation." In Africans and the Bible, ed. Vincent L. Winbush, 588-602. New York: Continuum, 2000.

Schaper, Donna. Sabbath Keeping. Cambridge, MA: Cowley Publications, 1999.

Sepulveda, Ciro. On the Margins of Empires: A History of Seventh-day Adventists. Huntsville, AL: Oakwood College Press, 2007.

Setran, David P., Jim Wilhoit, Donald Ratcliff, Daniel T. Haase, and Linda Rosema. "Spiritual Formation Goes to College: Class-related 'Soul Projects' in Christian Higher Education." 3rd series. Christian Education Journal 7, no. 2 (Fall 2010): 401-422.

"Seventh-day Adventist Philosophy of Education." General Conference Policy Manual (2003). Education - Departmental Policies: FE05, FE10. http://circle .adventist.org/download/PhilStat2003.pdf (accessed September 3, 2009).

Shaw, Talbert O. "Character Education: The Raison d'être of Historically Black Colleges and Universities." In How Black Colleges Empower Black Students: Lessons for Higher Education, edited by Frank W. Hale, Jr., 95. Sterling, VA: Stylus Publishing LLC, 2006.

Shulevitz, Judith. The Sabbath World: Glimpses of a Different Order of Time. New York: Random House, 2010.

Smith, Christian. Souls in Transition: The Religious and Spiritual Lives of Emerging Adults. Oxford, NY: Oxford University Press, 2009.

Smith, Huston. "In Defense of Spiritual Discipline." In Ultimate Reality and Spiritual Discipline, edited by James Duerlinger, 67-82. New York: Paragon House Publishers, 1984.

Smith, James Bryan, and Lynda Graybeal. A Spiritual Formation Workbook: SmallGroup Resources for Nurturing Christian Growth. San Francisco: HarperSanFrancisco, 1999.

Spangler, Patricia, ed. "Shandelle Henson and Jane Thayer Receive J. N. Andrews Medallion.” Focus, Spring 2009, 11. 
Specht, Walter F. "The Sabbath in the New Testament." In The Sabbath in Scripture and History, edited by Kenneth A. Strand, 92-113. Washington, DC: Review and Herald, 1982.

Speck, Bruce W. "What is Spirituality?" New Directions for Teaching \& Learning 104 (2005): 3-13.

Steele, Richard B. 'Sufficiently Edified' - The Use of Stories in the Spiritual Formation of College Students." Horizons 31, no. 2 (2004): 343-354.

Strand, Kenneth A. "The Sabbath." In Handbook of Seventh-day Adventist Theology, edited by Raoul Dederen, 496-506. Hagerstown, MD: Review \& Herald, 2000.

. The Sabbath in Scripture and History. Hagerstown, MD: Review and Herald, 1982.

Sullivan, John. "From Formation to the Frontiers: The Dialectic of Christian Education." Journal of Education and Christian Belief 7, no. 1 (2003): 7-21.

Swinton, John, and Harriet Mowat. Practical Theology and Qualitative Research. London, Englalnd: SCM Press, 2006.

Tasker, Carol. Spiritual Formation: Unexpected Surprises for Pastors. Ph.D. dissertation, Andrews University, 2001.

Tate, Yvonne Bissonnette, and Stephen Parker. "Using Eriksons's Developmental Theory to Understand and Nurture Spiritual Development in Christians." Journal of Psychology and Christianity 26, no. 3 (2007): 218-226.

Thayer, O. Jane. "Constructing a Spiritual Measure Based on Learning Theory: The Christian Spiritual Participation Profile." Journal of Psychology and Christianity 23, no. 3 (2004): 195-207.

. "A Statement of Seventh-day Adventist Educational Philosophy: Version 7.8." Special edition, Journal of Research on Christian Education 10 (2001): 347355 .

Thielicke, Helmut. How the World Began. Translated by John W. Doberstein. London, England: James Clark \& Company, 1963.

Thomas, Gary. Sacred Pathways: Discovering Your Soul's Path to God. Grand Rapids, MI: Zondervan, 1996.

Thompson, Marjorie J. Soul Feast: An Invitation to the Christian Spiritual Life. Louisville, KY: Westminster John Knox Press, 1995. 
Tidball, Derek J. Skillfull Shepherds: An Introduction to Pastoral Theology. Grand Rapids, MI: Zondervan, 1986.

Tisdell, Elizabeth. Exploring Spirituality and Culture in Adult and Higher Education. San Francisco: Jossey-Bass, 2003.

Tolliver, Derise, and Elizabeth Tisdell. "Engaging Spirituality in the Transformative Higher Education Classroom." New Directions for Adults and Continuing Education 109 (2006): 37-47.

Turner, Max M. B. “The Sabbath, Sunday and the Law in Luke/Acts.” In From Sabbath to Lord's Day, edited by D.A. Carson, 99-157. Grand Rapids: Zondervan, 1982.

Turner, William C. Discipleship for African American Christians: A Journey Through the Church Covenant. Valley Forge, PA: Judson Press, 2002.

Turner-Musa, Jocelyn, and La'Shaunna Lipscomb. "Spirituality and Social Support on Health Behaviors of African American Undergraduates." American Journal of Health Behavior 31, no. 5 (2007): 495-501.

Underhill, Evelyn. The Spiritual Life. Harrisburg, PA: Morehouse Publishing, 1937.

United States Census Bureau (2001, March 14). Questions and Answers for 2000 Data on Race. From United States Census Bureau. http://www.census.gov/Press-Release/ www/2001/raceqandas.html (accessed June 16, 2009).

Upper Room, Academy for Spiritual Formation, What Is the Academy? http://www .upperroom.org/academy/whatistheacademy.asp (accessed July 2, 2009). . About Us. http://www.upperroom.org/about/ (accessed July 2, 2009).

Vandeman, George E. When God Made Rest. Boise, ID: Pacific Press Association, 1987.

Vanden Berg, Mary L. "Bonhoeffer's Discipleship: Theology for the Purpose of Christian Formation." Calvin Theological Journal 44 (2009): 333-350.

Van Kaam, Adrian L. Transcendent Formation. New York: Crossroads Books, 1995.

Veling, Terry A. "Listening to 'The Voices of the Pages' and 'Combining the Letters': Spiritual Practices of Reading and Writing." Religious Education 102, no. 2 (Winter 2007): 206-222.

Waggoner, Brad J. The Shape of Faith to Come: Spiritual Formation and the Future of Discipleship. Nashville, TN: B \& H Publishing Group, 2008. 
Walker, Celeste perrino. Adventist Family Traditions to Bless Your Heart and Home. Nampa, ID: Pacific Press, 2002.

. Making Sabbath Special: Simple Traditions to Make the Sabbath a Delight. Nampa, ID: Pacific Press, 1999.

Wallis, Jim. The Great Awakening: Reviving Faith and Politics in a Post-Religious Right America. New York: HarperOne, 2008.

Walvoord, Barbara E. 'Students' Spirituality and 'Big Questions' in Introductory Religion Courses." Teaching Theology and Religion 11, no. 1 (2008): 3-13.

Warren, Mervyn A. "Old Wine in New Bottles: Visioning Values in Higher Education." In How Black Colleges Empower Black Students, ed. Frank W. Hale, Jr., 201. Sterling, VA: Stylus Publishing, LLC, 2006.

Washington, James Melvin. "Afterword: A Scholar's Benediction." In Conversations with God, edited by James Washington, 285-286. New York: HarperCollins, 1994.

Watt, Sherry K. "Come to the River: Using Spirituality to Cope, Resist, and Develop Identity." New Directions for Student Services 104 (Winter 2003): 29-40.

Welch, Ronald D. and Kimberlee Mellberg. "Spiritual Maturation and Religious Behaviors in Christian University Students." Christian Higher Education 7 (2008): 142.

Wertheim, Janie-Sue, and Kathy Shapiro. Walk With Y'Shua Through the Jewish Year. San Francisco: Purple Pomegranate Productions, 1998.

"What is a Seventh-day Adventist?" Wikipedia. http://en.wikipedia.org/wiki/SeventhdayAdventist (accessed June 16, 2009).

White, Ellen G. Child Guidance. Washington, DC: Review and Herald, 1954.

. Counsels to Parents and Teachers Regarding Christian Education. Mountain View, CA: Pacific Press, 1913.

.The Creation." In Patriarchs and Prophets, Mountain View, CA: Pacific

Press, 1958.

. The Desire of Ages. Mountain View, CA: Pacific Press, 1898.

. Early Writings. Washington, DC: Review and Herald, 1882.

. Education. Washington, DC: Review and Herald, 1952. 
. "Ellen G. White Comments - Revelation." Seventh-day Adventist Bible

Commentary. Edited by F. D. Nichol. Washington, DC: Review and Herald, 1953-57. 7:980.

. Gospel Workers. Washington, DC: Review and Herald, 1915.

. The Great Controversy. Mountain View, CA: Pacific Press, 1888.

. In Heavenly Places. Washington, DC: Review and Herald, 1967.

. Patriarchs and Prophets. Mountain View, CA: Pacific Press, 1958.

. Prophets and Kings. Mountain View, CA: Pacific Press, 1917.

. Sabbath Joy: Celebrating God's Special Day. Hagerstown, MD: Review and Herald, 1998.

. Signs of the Times, August 22, 1895.

. Sons and Daughters of God. Washington, DC: Review and Herald, 1955.

. "The Source and Aim of True Education." In Education. http://www

.ellenwhite.org/sl/ed01.htm (accessed September 4, 2009).

. Steps to Christ. Mountain View, CA: Pacific Press, 1956.

. The Southern Work. Hagerstown, MD: Review and Herald, 2004.

. Testimonies to the Church 9 vols. Mountain View, CA: Pacific Press, 1948.

Whitney, Donald S. Simplify Your Spiritual Life: Spiritual Disciplines for the Overwhelmed. Colorado Springs: NavPress, 2003. 1991.

. Spiritual Disciplines for the Christian Life. Colorado Springs, CO: NavPress,

Wilhoit, James C. Spiritual Formation as If the Church Mattered. Grand Rapids, MI: Baker Books, 2008.

Wilhoit, Kenneth O. The Christian Educator's Handbook on Spiritual Formation. Grand Rapids, MI: Baker Books, 1994.

Willard, Dallas. Renovation of the Heart: Putting on the Character of Christ. Colorado Springs, CO: NavPress, 2002. 
The Spirit of the Disciplines: Understanding How God Changes Lives. San Francisco: HarperSanFrancisco, 1991.

. "Spiritual Formation in Christ: A Perspective on What It Is and How It Might Be Done." Journal of Psychology \& Theology 28, no. 4 (2000): 254.

Winner, Laura. Mudhouse Sabbath. Brewster, MS: Paraclete, 2003.

Wirzba, Norman. Living the Sabbath: Discovering the Rhythms of Rest and Delight. Grand Rapids, MI: BrazosPress, 2006.

Wolfson, Ron. The Art of Jewish Living: The Shabbat Seder. New York: The Federation of Jewish Men's Clubs and the University of Judaism, 1985.

Wood, Charles M. “'Spiritual Formation' and 'Theological Education'." Religious Education 86, no. 4 (1991): 550.

Wuthnow, Robert. After the Baby Boomers: How Twenty-and Thirty-Somethings Are Shaping the Future of American Religion. Princeton, RI: Princeton University Press, 2007.

Young, Yarna Cerna. Oh No, It's Sabbath Again and I'm Not Ready: A Homemaker's Guide to Making Friday the Easiest Day of the Week. Boise, ID: Pacific Press, 1992.

Youngberg, Millie, and John Youngberg. Family Sabbath Traditions to Bless Your Heart and Home. Nampa, ID: Pacific Press, 2001.

Zirschky, D. Andrew. "Presence-Centered Youth Ministry: Guiding Students into Spiritual Formation." Journal of Youth Ministry 6 no. 1 (2007): 120-124.

Zodhiates, Spiros, ed. The Hebrew-Greek Study Bible. Chattanooga, TN: AMG Publishers, 1984. 
Name: Ifeoma I. Kwesi

Date of Birth: $\quad$ September 18, 1948

Place of Birth: $\quad$ Topeka, Kansas

Children: $\quad$ Renene Price (1968)

\section{Education}

2003-2012

Doctor of Ministry in African American Studies, Andrews University, Berrien Springs, Michigan

2003-2005

1990-1993

1966-1972

Certification from the Academy of Spiritual Formation, Nashville, Tennessee

Master of Divinity, Andrews University, Berrien Springs, Michigan

Bachelor of Arts in Psychology and History, University of South Alabama, Mobile, Alabama

\section{Experience}

2002-2012

Assistant Professor, Department of Religion \& Theology, Oakwood University, Huntsville, Alabama

1998-2002

$1997-1998$

1993-1996

Senior Pastor, Palo Alto Seventh-day Adventist Church, Palo Alto, California

Associate Pastor, Kansas Avenue Seventh-day Adventist Church, Riverside, California

Senior Pastor, Oak Park Seventh-day Adventist Church, San

Diego, California 